\title{
Middle Cretaceous (Cenomanian) bivalves from the Karai Formation, Uttattur Group, of the Cauvery Basin, south India
}

\author{
George W. Kendrick ${ }^{1}$ and Ajit V. Vartak ${ }^{2}$ \\ 'Department of Earth and Planetary Sciences, Western Australian Museum, 49 Kew Street, \\ Welshpool 6106, Australia; and School of Earth and Geographical Sciences, \\ The University of Western Australia, Crawley 6009, Australia \\ ${ }^{2}$ Department of Geology and Petroleum Technology, Nowrosjee Wadia College, Pune 411001, India
}

\begin{abstract}
Sixty species of Bivalvia, representing 28 families and 41 genera, are recorded from three outcrops of the Karai Formation (Uttattur Group, Cauvery Basin) near Odiyam village, Tiruchirapalli district, south India. Both Kunnam and Odiyam Members of the Formation are represented in the study material. An undifferentiated Cenomanian age is assigned to the fossil assemblages.

All species are described as fully as preservation and representation allow. Twenty three are redescribed with revised taxonomy. Newly described and named are the following 17 species: Nuculana $(N$.) odiyamensis, Nuculana (N.) arenicola, Grammatodon (Nanonavis) subcrenulatus, Trigonarca (Costelliarca) punctulata, Atreta redunca, Callucinella marcida, Callucinopsis? dalmiana, Paramyrtea (new genus) sabulosa, Goodallia salebrosa, Goodallia? australindica, Eriphyla (Miyakoella) badvei, Aenona? ariana, Aphrodina (A.) plebeia, Caryocorbula cauveriensis, Caestocorbula kubera, Lentidium (Janschinella) dissitum and Barcoona? gradilis. One new genus - Paramyrtea - is erected. Lectotypes are designated for 18 species. Six families - Noetiidae, Limopsidae, Propeamussiidae, Fimbriidae, Crassatellidae and Pholadomyidae - are recorded for the first time from the Uttattur Group.

Mollusca dominate the macro-assemblages. The bivalves constitute a diverse community of the transgressive, silty to sandy inner shelf, moderately energised and with good oceanic exchange at depths within the photic zone. Most of the genera are widely distributed in the Austral and MediterranCaucasian Realms of the Middle Cretaceous. Generic/subgeneric endemism is low, not exceeding $5 \%$.
\end{abstract}

Keywords: Cretaceous, Bivalvia, Karai Formation, Uttattur Group, Cauvery Basin, India.

\section{INTRODUCTION}

This study arose from the project "Revision of the Cretaceous palaeontology of India", which was initiated in 1968-69 under the guidance of the late Professor G.W. Chiplonkar at the then Maharashtra Association for the Cultivation of Science (MACS), now Agharkar Research Institute (ARI), Pune. Macrofossils, principally from outcrops of the Cauvery Basin of south-eastern India, were the focus of these studies, initially as thesis work at the University of Poona, by Tapaswi (1973) on bivalves, Phansalkar (1975) on acanthoceratid ammonites, Oka (1980) on desmoceratid ammonites, Purohit (1980) on gastropods, Aziz (1985) on echinoids and brachiopods and by Vartak (1990) on heteromorph ammonites. These and other published work on the Bivalvia (see Chiplonkar 1987) have enlarged upon the pioneering studies of Forbes (1846), d'Orbigny (1847), Stoliczka (1870, 1871), Kossmat (1895-1898) and Spengler (1914).

The Cretaceous of the Ariyalur-Pondicherry Subbasin has long been a prolific source of diverse and well-preserved invertebrate fossils, prominent among which have been the Mollusca. Most of these, as shown from earlier studies, came from calcareous units of the Trichinopoly and Ariyalur Groups. The present contribution aims to extend knowledge of the less familiar assemblages of the older Uttattur Group, as represented by the Karai Formation. We have collected 60 species of Bivalvia from three small outcrops of "shelly limestone" of the Karai Formation near the village of Odiyam (Figure 1). With the addition of these, a new total of 142 bivalve species is now recognised from the Uttattur Group. Twenty three previously described species are re-described with revised taxonomy, where possible with reference to the type material. Sixteen new species are named and 21 left in open nomenclature. One new genus is introduced.

\section{MATERIAL AND LOCALITIES}

The study material, kindly made available to us from the research collections of the Agharkar 
Research Institute, Pune, was collected from three small outcrops of "shelly limestone" near Odiyam village (latitude $11^{\circ} 13^{\prime} 00^{\prime \prime} \mathrm{N}$, longitude $78^{\circ} 59^{\prime} 30^{\prime \prime} \mathrm{E}$ ), which is located $2.5 \mathrm{~km}$ south of the AriyalurPerambalur road in Perambalur Taluk and ca $60 \mathrm{~km}$ northeast from the city of Tiruchirapalli (=Trichinopoly of earlier works) in Tamil Nadu State. The positions of Odiyam village and other localities cited in the text are shown in Figure 1. Fossil locality details are:

Odiyam Locality 1. Hard, well-cemented, greyishbrown, ammonite-rich, quartzose, shelly calcarenite and coquinite $1.2 \mathrm{~km}$ west of Odiyam village. As found, the deposit presented an unusual concentration of heteromorph ammonites and numerous belemnite phragmocones. Collection by A.V. Vartak in May 1981 and November 1983. A return visit to the site by the present authors in December 1989 revealed that the outcrop had been strip-mined for limestone, so that further collecting proved unproductive.

Odiyam Locality 2. Slightly friable, brown, calcareous siltstone with abundant turritellid gastropods, forming low outcrop beside track ca 0.5 $\mathrm{km}$ west of Odiyam village. Collection by the authors in December 1989.

Odiyam Locality 3. Hard, greyish-brown, quartzose, shelly limestone with abundant single valves of Trigonarca, along nullah [a normally dry, ephemeral stream bed] ca $1.0 \mathrm{~km}$ south of Odiyam village. Collection as for Locality 2. This unit overlies a brown sandstone containing the ammonite Calycoceras newboldi (Kossmat).

Fossils, almost entirely molluscan shells, were separated carefully from sediment to the extent possible, sorted into species and allocated numbers from the palaeontological catalogue of the Agharkar Research Institute (ARI), Pune. From Odiyam Locality 1, bivalves are numbered in the catalogue sequence G2681 to G2722; from Locality 2, G2759 to G2798; G4340 and G4352 to G4354; and G4400; from Locality 3, G2874 to G2930, G2759 to G2798.
In the course of this study, other comparative material was examined from the Stoliczka Collection, Geological Survey of India, Kolkata; Natural History Museum, London; Koninklijk Belgisch Instituut voor Natuurwetenschappen, Brussels; The Australian Museum, Sydney, New South Wales and the Western Australian Museum, Perth.

All holotypes, paratypes and other study material from Odiyam Localities 1, 2 and 3, cited below, are to be deposited in the collections of the Agharkar Research Institute, Pune.

Abbreviations employed in the text and captions are:

ARI Agharkar Research Institute, Pune

GSI Geological Survey of India, Kolkata

NHM Natural History Museum, London

WAM Western Australian Museum, Perth

LV left valve

$\mathrm{RV}$ right valve

Specimen dimensions are in millimetres.

\section{Geological setting and stratigraphy}

The Cauvery Basin extends for nearly $400 \mathrm{~km}$ along the south-eastern coast of peninsular India between latitudes $12^{\circ}$ and $9^{\circ} \mathrm{N}$ in the Union State of Tamil Nadu. It forms the southern-most of several NE to SW trending, marginal-cratonic basins of the region, formed by deformation of the Archaean crystalline basement during the Late Jurassic-Early Cretaceous separation of the India-Madagascar island from Gondwanan Australia-Antarctica (Westermann 2000). General features and tectonic history of the Cauvery Basin have been reviewed recently by Sundaram et al. (2001:743-762), whose stratigraphic interpretations and terminology are followed herein. Sequence stratigraphy of the Cauvery Basin Cenomanian, with evidence for globally synchronous, $400,000 \mathrm{k} . \mathrm{y}$. eustatic cycles, is reported by Gale et al. (2002).

Cretaceous (Albian to Maastrichtian) sediments, mostly marine and often richly fossiliferous, crop

Table 1 Cretaceous stratigraphy of the Ariyalur-Pondicherry Sub-basin, after Sundaram et al. (2001). Unconformities shown - - -

\begin{tabular}{|c|c|c|}
\hline Groups & Formations & Ages \\
\hline Ariyalur Group & $\begin{array}{l}\text { Kallemedu Formation } \\
\text { Kallakurichchi Formation } \\
\text { Sillakkudi Formation }\end{array}$ & $\begin{array}{l}\text { Maastrichtian } \\
\text { Early Maastrichtian } \\
\text { Santonian-Campanian }\end{array}$ \\
\hline Trichinopoly Group & $\begin{array}{l}\text { Anaipadi Formation } \\
\text { Kulakkalnattam Formation }\end{array}$ & $\begin{array}{l}\text { Turonian-Coniacian } \\
\text { Turonian }\end{array}$ \\
\hline Uttattur Group & $\begin{array}{l}\text { Karai Formation } \\
\text { Dalmiapuram Formation } \\
\text { Arogyapuram Formation } \\
\text { Terani Formation }\end{array}$ & $\begin{array}{l}\text { Albian-Turonian } \\
\text { Albian } \\
\text { Albian } \\
\text { Albian }\end{array}$ \\
\hline
\end{tabular}




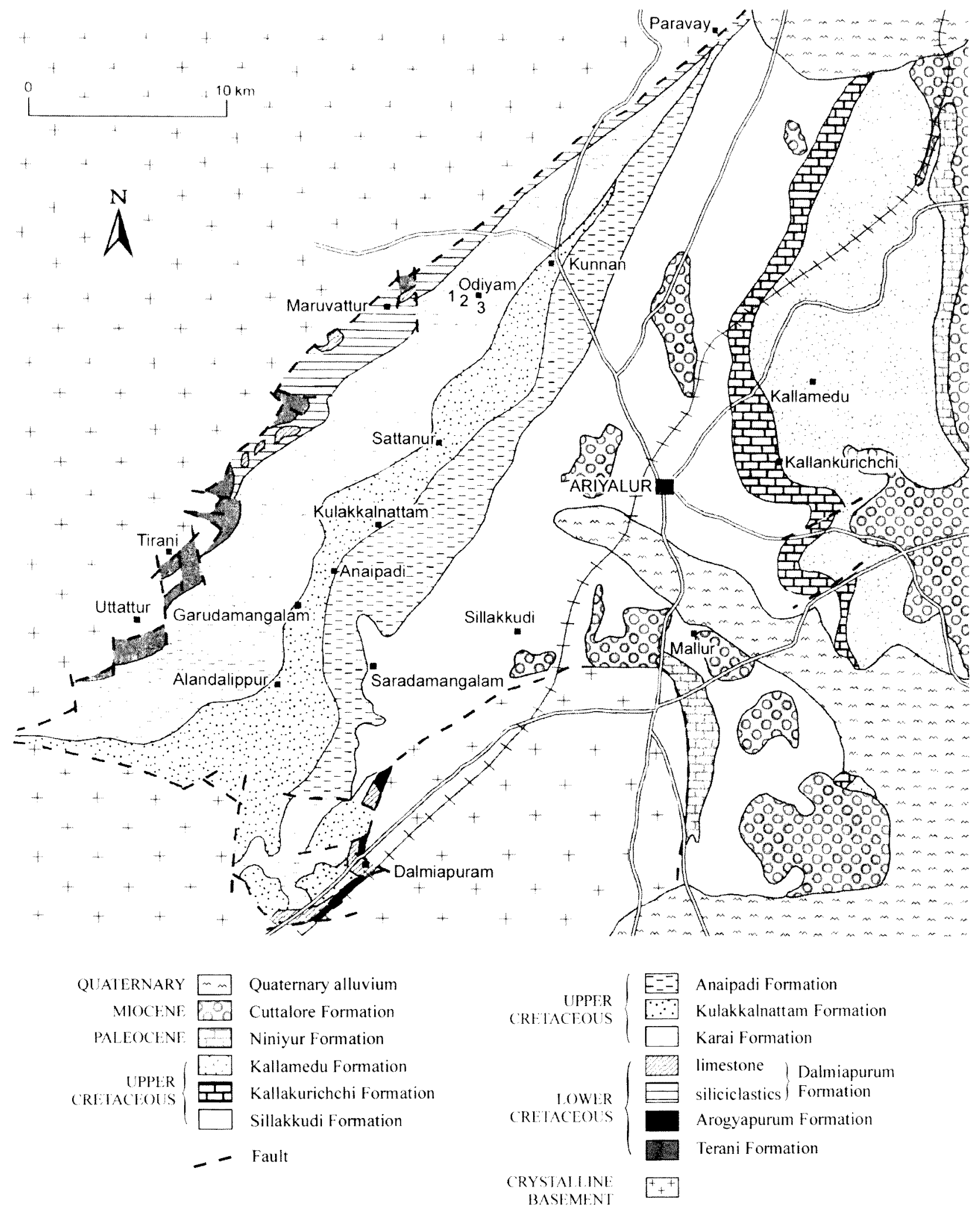

Figure 1 Surface geology of the Ariyalur-Odiyam district showing distributions of Cretaceous and younger formations. After Sundaram et al. (2001, fig. 3). Fossil localities shown 1-3.

out extensively along the western part of the Ariyalur-Pondicherry Sub-basin (Figure 1), representing passive-margin deposition within a shallow embayment opening to the (modern) northeast. They unconformably overlie Archaean basement charnockites of the Eastern Ghats Mobile Belt, the uplands of which form the western margin of the Sub-basin. Regional dips to the east or southeast are low $\left(5^{\circ}-10^{\circ}\right)$; minor local faulting is (Text continued $p$.8) 
Table 2 Bivalvia recorded from the Uttattur Group (Late Albian-Early Turonian), Cauvery Basin, south India. Sources 1: Stoliczka 1870, 1871. 2: This paper. 3: Others, combined (Ayyasami and Banerji 1984, Ayyasami and Jagannatha Rao 1979, 1980, Badve 1977, Chiplonkar and Tapaswi 1975a, 1975b, 1976a, 1976b, 1976c, 1977, 1979, Dhondt 1973, Tapaswi 1987).

Species, by families

1. Family Nuculidae

1. Nucula (N.) bidorsata Stoliczka

2. Nucula sp.

3. Leionucula sp. cf. L. albensis (d'Orbigny)

4. Nuculana (N.) socialis Stoliczka

2. Family Nuculanidae

5. Nuculana (N.) odiyamensis sp. nov.

6. Nuculana (N.) arenicola sp. nov.

7. Nuculana sp.

8. Isoarca gibba Stoliczka

3. Family Isoarcidae

4. Family Noetiidae

9. Noetiid, genus and species undetermined

5. Family Parallelodontidae

10. Grammatodon (Nanonavis) subcrenulatus sp. nov.

11. Nemodon (N.) filistriata (Stoliczka)

6. Family Cucullaeidae

12. Trigonarca (Costelliarca) trichinopolitensis (Forbes)

13. Trigonarca (C.) gamana (Forbes)

14. Trigonarca (C.) punctulata sp. nov.

7. Family Limopsidae

15. Limopsis coemansi Briart and Cornet

16. Limopsis sp. A

17. Limopsis sp. B

8. Family Glycymeridae

18. Glycymerita (G.) cardioides (d'Orbigny)

9. Family Nucinellidae

19. Nucinella glabrata Stoliczka

10. Family Inoceramidae

20. Inoceramus (I.) pictus J. Sowerby

21. Inoceramus geinitzianus Stoliczka

22. Inoceramus multiplicatus Stoliczka

23. Inoceramus concentricus Parkinson

24. Inoceramus inaequivalvis Schlüter

25. Inoceramus hoepeni Heinz

26. Inoceramus hobetsensis Nagao and Matsumoto

27. Inoceramus comancheanus comancheanus Cragin

28. Inoceramus comancheanus elongatus Chiplonkar and Tapaswi

29. Inoceramus comancheanus apicatus Chiplonkar and Tapaswi

30. Inoceramus lucidus Chiplonkar and Tapaswi

31. Inoceramus sp. cf. I. stantoni Sokolow

32. Mytiloides labiatus (Schlotheim)

33. Mytiloides labiatus obliquus (Chiplonkar and Tapaswi)

34. Mytiloides labiiformis (Chiplonkar and Tapaswi)

35. Mytiloides labiiformis kunnamensis (Chiplonkar and Tapaswi)

36. Mytiloides mytiloides (Mantell)

37. Mytiloides borkari (Chiplonkar and Tapaswi)

38. Mytiloides sp. cf. M. pronus (Chiplonkar and Badve)

39. Cataceramus sp. cf. C. bellvuensis Reeside

40. Sphenoceramus diversus (Stoliczka)
1$$
+
$$$$
+
$$$$
+
$$

$$
\begin{aligned}
& + \\
& + \\
& +
\end{aligned}
$$




\section{Species, by families}

11. Family Mytilidae

41. "Mytilus (M.)" gallieni kunnamensis Chiplonkar and Tapaswi

42. "Mytilus (M.)" sp.

43. Brachidontes (B.) sp.

44. Lithophaga curta (Stoliczka)

45. Modiolus subcylindrica (Stoliczka)

12. Family Pinnidae

46. Pinna intumescens Stoliczka

47. Pinna sp.

48. Atrina laticostata (Stoliczka)

13. Family Isognomonidae

49. Isognomon (I.) sp. cf. I. (I.) oblonga Seeley

50. Isognomon (I.) securiformis Chiplonkar and Tapaswi

14. Family Limidae

51. Lima (L.) insignis (Stoliczka)

52. Lima (L.) sp.

53. Indoctenostreon complanata (Stoliczka)

54. Limatula persimilis (Stoliczka)

55. Ctenoides sp.

56. Plagiostoma ootatoorensis (Stoliczka)

57. Plagiostoma interpunctuata (Stoliczka)

58. Acesta (A.) obliquistriata (Forbes)

15. Family Gryphaeidae

59. Pycnodonte vesiculosa (J. Sowerby)

60. Pycnodonte poordoorensis (Stoliczka)

61. Exogyra haliotoidea (Sowerby)

62. Exogyra? canaliculata (Sowerby)

63. Exogyra (Costagyra) costata Say

64. Rhynchostreon suborbiculatum (Lamarck)

16. Family Ostreidae

65. Lopha (Actinostreon) diluviana (Linnaeus)

66. Rastellum (Arcostrea) carinatum (Lamarck)

17. Family Plicatulidae

67. Plicatula (Darteplicatula) sessilis Stoliczka

18. Family Dimyidae

68. "Diploschiza" spp.

69. Atreta redunca sp. nov.

70. Atretasp.

19. Family Entoliidae

71. Entolium? obovatum (Stoliczka)

72. Entolium? sivaicum (Stoliczka)

73. Syncyclonema? sp.

20. Family Propeamussiidae

74. Parvamussium sp.

21. Family Neitheidae

75. Neithea (N.) quinquecostata (Sowerby)

76. Neithea (N.) laevis (Drouet) $=N$. (N.) aequicostata (Lamarck)

77. Neithea (N.) sp.cf. N. (N.) hispanica (d'Orbigny)

78. Neithea (N.) gibbosa (R. Pulteney)

79. Neithea (N.) pseudobellula Chiplonkar and Tapaswi

80. Neithea (N.) pseudobellula elevata Chiplonkar and Tapaswi 


\section{Species, by families}

22. Family Pectinidae

81. Chlamys (C.) verdachellensis (Forbes)

82. Chlamys (C.) sattanurensis Chiplonkar and Tapaswi

83. Chlamys (C.) subbaramani Chiplonkar and Tapaswi

84. Chlamys (C.) raduloides (Stoliczka)

85. Chlamys (C.) sp.

86. Hinnites andoorensis Stoliczka

87. Nippononectes $\mathrm{sp}$.

23. Family Spondylidae

88. Spondylus subcostulatus Stoliczka

89. Spondylus costuliferus Chiplonkar and Tapaswi

90. Buchia parva (Stoliczka)

24. Family Buchiidae

25. Family Lucinidae (see text)

91. "Lucina fallax Forbes", sensu Stoliczka 1871

92. Mesomiltha sp. cf. M. fallax (Forbes)

93. Mesomiltha? sp.

94. Callucinella marcida sp. nov.

95. Myrtea (M.) arcotina (Stoliczka)

96. Callucinopsis? dalmiana sp. nov.

97. Paramyrtea sabulosa gen. nov., sp. nov.

98. Lucinid, genus and species undetermined, sp. A

99. Lucinid, genus and species undetermined, sp. B

100. Fimbria sp.

\section{Family Fimbriidae}

\section{Family Crassatellidae}

101. Anthonyasp.

28. Family Astartidae

102. Astarte (A.) jugosa Forbes

103. Astarte (A.) planissima Forbes

104. Goodallia salebrosa sp. nov.

105. Goodallia? australindica sp. nov.

106. Eriphyla (Miyakoella) badvei sp. nov.

107. Opis (O.) repleta Stoliczka

108. Opis (O.) geinitziana (Stoliczka)

29. Family Cardiidae

109. Granocardium productum (Sowerby)

110. Protocardia (P.) alta (Sowerby in Forbes)

111. Protocardia (P.) bisecta (Forbes)

112. Protocardia (P.) hillana (Sowerby)

113. Profragum praecurrens (Stoliczka)

114. Pratulum scrobiculatum (Stoliczka)

30. Family Tellinidae

Tellina mendosa Stoliczka

116. Tellina adpressa Stoliczka

117. Tellina discites Stoliczka

118. Linearia sp.

119. Aenona? ariana sp. nov.

31. Family Veneridae

120. Aphrodina (A.) fabulina (Stoliczka)

121. Aphrodina (A.) plebeia sp. nov.

122. Mesocallista (M.) turgidula (Stoliczka)

123. Mesocallista (M.) sp. cf. M. (M.) analoga (Forbes)

124. Mesocallista (M.) vagrans (Stoliczka) 
Table 2 (cont.)

\section{Species, by families}

125. Mesocallista (M.) sp.

126. Legumen pondicherriensis (Forbes)

127. Caryocorbula minima (d'Orbigny)

32. Family Corbulidae

128. Caryocorbula cauveriensis sp. nov

129. Caestocorbula kubera sp. nov.

130. Lentidium (Janschinella) dissitum sp. nov.

33. Family Gastrochaenidae

131. Gastrochaena guttula (Stoliczka)

34. Family Hiatellidae

132. Hiatella tenella (Stoliczka)

35. Family Pholadidae

133. Xylophagella crassula (Stoliczka)

134. Xylophagella partita (Stoliczka)

135. Martesia tundens Stoliczka

136. Goniochasma torulosa (Stoliczka)

137. Parapholas mersa Stoliczka

138. Turnus lapidarius Stoliczka

36. Family Teredinidae

139. Sphaerulites indica Stoliczka

37. Family Caprotinidae

38. Family Cuspidariidae

140. Cuspidaria (C.) detecta (Stoliczka)

39. Family Pholadomyidae

141. Goniomya (G.) sp.

40. Family undetermined

142. Barcoona? gradilis sp. nov.

Sub-totals $\quad 68 \quad 60 \quad 45$

Table 3 Bivalve families (39) recorded (all sources) from the Uttattur Group in order of number of known taxa (species or subspecies). Note that 15 families are represented by a single taxon and there is one additional species of undetermined family. Asterisks (6) denote first record of family from Uttattur Group.

$\begin{array}{ll}\text { Families } & \text { Recorded Taxa }\end{array}$

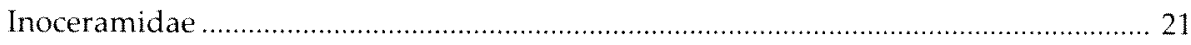

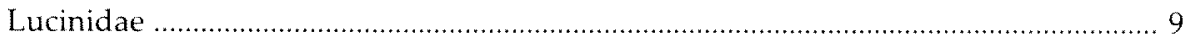

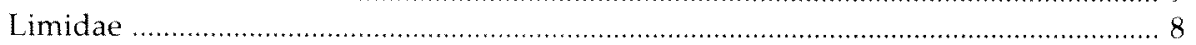

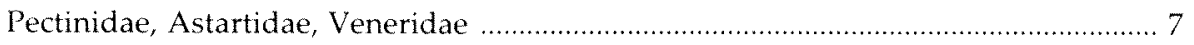

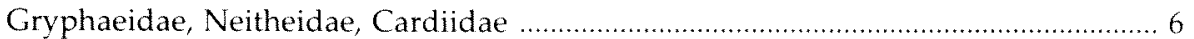

Mytilidae, Tellinidae, Pholadidae .......................................................................... 5

Nuculanidae, Corbulidae ...................................................................... 4

Nuculidae, Cucullaeidae, Limopsidae*, Pinnidae, Dimyidae, Entoliidae ................... 3

Parallelodontidae, Ostreidae, Isognomonidae, Spondylidae ...................................... 2

Isoarcidae, Noetiidae*, Glycymeridae, Nucinellidae, Plicatulidae,

Propeamussidae*, Buchiidae, Fimbridae*, Crassatellidae*,

Gastrochaenidae, Hiatellidae, Teredinidae,

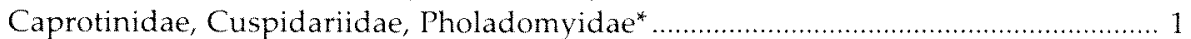

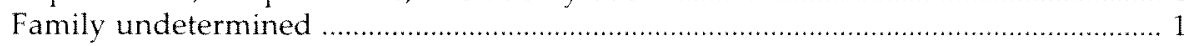


common. Since the pioneering contribution of Blanford (1862), a tripartite lithostratigraphic subdivision of the Cretaceous of the AriyalurPondicherry Sub-basin has been recognised. The above tabulation of Blanford's Groups (Table 1), with revised formation terminology and ages follows Sundaram et al. (2001).

The Karai Formation (Sundaram and Rao 1986) is the uppermost and principal unit of the Uttattur Group, comprising greyish-brown to brown, often gypsiferous mudstone, siltstone and marl, with sporadic quartzose calcarenite, calcareous sandstone and coquinite. Much of the area of outcrop typically forms "bad land" terrain; carbonate units are often richly fossiliferous, predominantly molluscan, and are the source of the present study material. This originates from within the area mapped by Ayyasami and Banerji (1984, fig. 1) as "Gypseous shales with interbedded biostromal limestones".

Two members of the Karai Formation have been defined from the area between Odiyam and Kunnam villages (Sundaram et al. 2001). Our more arenaceous and strongly lithified material from Odiyam Localities 1 and 3 is assigned provisionally to the Kunnam Member, and may correspond to the Mid-Late Cenomanian eustatic high (Hancock 2000:4-5, Sundaram et al. 2001: 760, fig. 8). Material from the more argillaceous Odiyam Locality 2 may represent the Early Cenomanian Odiyam Member (see below, Age).

The Karai Formation overlies conformably the grey shales, mudstone, limestone, coquinite, calcareous sandstone and quartzose conglomerate of the Late Albian Dalmiapuram Formation (Bhatia and Jain 1969). Synonyms are Maruvattur Formation of Sundaram and Rao (1986) and Kallakudi Limestone of authors. Along its eastern and southern flanks, the Karai Formation is overlain with angular unconformity by the sandstones, conglomerates, mudstones, shale and coquinite of the Turonian Kulakkalnattam Formation, the basal unit of the Trichinopoly Group (Sundaram and Rao 1986).

The Garudamangalam Formation of Banerji (1973) is the exact equivalent of Blanford's (1862) Trichinopoly Group, which takes precedence (Sundaram et al. 2001). A three-part subdivision of the "Garudamangalum Formation", proposed by Ramasamy and Banerii (1991), is rejected in favour of the two-part subdivision (Kulakkalnattam and Anaipadi Formations) of the Group by Sundaram and Rao (1986).

\section{Age}

A convergence of evidence from ammonite and foraminiferal data (Sastry et al. 1968, Ayyasami 1990), summarised by Sundaram et al. (2001: 751, fig. 5) has established a Late Albian-Early Turonian age-range for the Karai Formation. Evidence supporting a Cenomanian age for the study material comes from ammonite (Localities 1 and 2) and inoceramid (Locality 3) data. From their relatively coarse-grained, calcareous, sandy/ coquinite lithologies, Localities 1 and 3 are assigned to the Kunnam Member of the Karai Formation; the fine-textured, silty Locality 2 is identified with the Odiyam Member.

From Locality 1, most westerly of our sources, an assemblage of ammonites was recorded by Vartak (1990). These included the species Turrilites (T.) acutus Passy, Hypoturrilites tuberculatus (Bosc), Hypoturrilites gravesianus (d'Orbigny), Scaphites obliquus (J. Sowerby), Scaphites daileyi Wright, Sciponoceras baculoide (Mantell) and Sciponoceras roto Cieslinski, an assemblage suggesting either a Lower or Middle Cenomanian age (R.A. Henderson, personal communication December 1998). With reference to the generalised stratigraphic succession of the Ariyalur district in Sundaram et al. (2001, fig. 5) and Gale et al. (2002, fig. 3), we propose a probable Middle Cenomanian age for the Locality 1 records and a stratigraphic location toward the base of the Kunnam Member.

The Locality 3 assemblage, from a coarse coquinite with abundant Trigonarca valves, overlies a brown sandstone containing the Middle Cenomanian Calycoceras newboldi (Kossmat). A single, imperfectly preserved valve of Inoceramus (I.) pictus J. Sowerby of indeterminable subspecies is included in the Locality 3 material, suggesting an age-range of Middle to Late Cenomanian (Turrilites acutus Zone) and Early Turonian (Watinoceras coloradoense Zone) (Dhondt 1992, Hancock 2000,

$$
\text { (Text continued p.10) }
$$

Table 4 Stratigraphic ranges of ammonite species recorded from Odiyam Locality 1 by Vartak (1990).

\begin{tabular}{lll}
\hline Species & Lower & $\begin{array}{c}\text { Cenomanian } \\
\text { Middle }\end{array}$ \\
\hline Turrilites (Turrilites) acutus Passy & \\
Hypoturrilites tuberculatus Bosc \\
Hypoturrilites gravesianus (d'Orbigny) \\
Sciponoceras baculoide (Mantell) \\
Sciponoceras roto Cieslinski \\
Scaphites obliquus (Sowerby) \\
Scaphites dailyi Wright
\end{tabular}


Table 5 Time-ranges of species in the study material from Odiyam. For details, see text. The Cenomanian is subdivided informally into $\mathrm{E}$ (Early), M (Middle) and L (Late). Asterisk ${ }^{*}$ ) denotes records beyond Cauvery Basin.

\begin{tabular}{|c|c|c|c|c|c|c|c|c|c|c|}
\hline \multirow{3}{*}{\multicolumn{2}{|c|}{ Species }} & \multicolumn{9}{|c|}{ Stages } \\
\hline & & \multirow[t]{2}{*}{ Albian } & \multicolumn{3}{|c|}{ Cenomanian } & \multirow{2}{*}{$\begin{array}{l}\text { Turo- } \\
\text { nian }\end{array}$} & \multirow{2}{*}{$\begin{array}{c}\text { Conia- } \\
\text { cian }\end{array}$} & \multirow{2}{*}{$\begin{array}{l}\text { Santo- } \\
\text { nian }\end{array}$} & \multirow{2}{*}{$\begin{array}{c}\text { Campa- } \\
\text { nian }\end{array}$} & \multirow{2}{*}{$\begin{array}{l}\text { Maas- } \\
\text { trictian }\end{array}$} \\
\hline & & & $\mathrm{E}$ & $\mathbf{M}$ & $\mathbf{L}$ & & & & & \\
\hline 1. & Nucula (N.) bidorsata Stoliczka & + & + & + & + & & & & & \\
\hline 2. & Leionucula (L.) sp. cf. L.(L.) albensis (d'Orbigny) & & + & + & + & & & & & \\
\hline 3. & Nuculana (N.) odiyamensis sp. nov. & & + & + & & & & & & \\
\hline 4. & $N .(N$.$) arenicola sp. nov.$ & & + & + & + & & & & & \\
\hline 5. & Noetiid, genus and species undetermined & & & & + & & & & & \\
\hline 6. & Grammatodon (Nanonavis) subcrenulatus sp. nov. & & + & + & + & & & & & \\
\hline 7. & Nemodon (N.) filistriata (Stoliczka) & & + & + & + & & & & & \\
\hline 8. & Trigonarca (Costelliarca) trichinopolitensis (Forbes) & & + & & + & + & + & & & + \\
\hline 9. & T. (C.) gamana (Forbes) & & + & & + & $+?$ & $+?$ & & $+?$ & $+?$ \\
\hline 10. & T. (C.) punctulata sp. nov. & & + & + & + & & & & & \\
\hline 11. & Limopsis (L.) coemansi Briart and Cornet & * & + & + & + & & & & & \\
\hline 12. & L.sp. A & & + & + & & & & & & \\
\hline 13. & L. sp. B & & + & + & & & & & & \\
\hline 14. & Glycymerita (G.) cardioides (d'Orbigny) & $+?$ & + & + & & $+?$ & $+?$ & & & + \\
\hline 15. & Inoceramus (I.) pictus J. Sowerby & & & * & + & + & & & & \\
\hline 16. & Pinna sp. & & & + & & & & & & \\
\hline 17. & Limatula persimilis Stoliczka & & + & + & + & & & & & \\
\hline 18. & Plagiostoma ootatoorensis (Stoliczka) & & & & + & & & & & \\
\hline 19. & Pycnodonte vesiculosa (J. Sowerby) & $+?$ & + & + & + & $+?$ & & * & & \\
\hline 20. & Plicatula (Darteplicatula) sessilis Stoliczka & + & + & & + & & & & & \\
\hline 21. & Atreta redunca sp. nov. & & + & + & + & & & & & \\
\hline 22. & Atreta sp. & & & & + & & & & & \\
\hline 23. & Syncyclonema? sp. & & + & + & + & & & & & \\
\hline 24. & Parvamussium sp. & & + & + & & & & & & \\
\hline 25. & Neithea (N.) aequicostata (Lamarck) & * & + & & & * & & & & \\
\hline 26. & $N$. (N.) sp. cf. N. (N.) hispanica (d'Orbigny) & & & & + & & & & & \\
\hline 27. & N. (N.) gibbosa (R. Pulteney) & & & & + & * & & & & \\
\hline 28. & N. (N.) quinquecostata (J. Sowerby) & * & + & + & & $+?$ & $+?$ & $+?$ & $+?$ & * \\
\hline 29. & N. (N.) pseudobellula Chiplonkar and Tapaswi & & + & & + & & & & & \\
\hline 30. & Nippononectes sp. & & & + & & & & & & \\
\hline 31. & Callucinopsis? dalmiana sp. nov. & & & & + & & & & & \\
\hline 32. & Callucinella marcida sp. nov. & & + & & & & & & & \\
\hline 33. & Mesomiltha sp. cf. M. fallax (Forbes) & + & + & + & & & & & & \\
\hline 34. & Mesomiltha? sp. & & + & + & + & & & & & \\
\hline 35. & Paramyrtea sabulosa gen. nov., sp. nov. & & + & + & + & & & & & \\
\hline 36. & Lucinid, genus undetermined sp. A & & & + & + & & & & & \\
\hline 37. & Lucinid, genus undetermined sp. B & & & & + & & & & & \\
\hline 38. & Fimbria sp. & & + & + & & & & & & \\
\hline 39. & Anthonya sp. & & + & & + & & & & & \\
\hline 40. & Goodallia salebrosa sp. nov. & & + & + & & & & & & \\
\hline 41. & Goodallia? australindica sp. nov. & & + & & + & & & & & \\
\hline 42. & Eriphyla (Miyakoella) badvei sp. nov. & + & + & & & & & & & \\
\hline 43. & Protocardia ( $P$.) alta (Sowerby in Forbes) & $+?$ & & & + & + & & & & \\
\hline 44. & Profragum praecurrens (Stoliczka) & & + & & + & + & & & & \\
\hline 45. & Pratulum scrobiculatum (Stoliczka) & & + & + & + & + & & & & \\
\hline 46. & Linearia sp. & & + & & + & & & & & \\
\hline 47. & Aenona? ariana sp. nov. & & + & + & & & & & & \\
\hline 48. & Aphrodina (A.) plebeia sp. nov. & & + & + & & & & & & \\
\hline 49. & A. (A.) fabulina (Stoliczka) & & & & + & + & & & & \\
\hline 50. & Mesocallista (M.) sp. of. M. (M.) analoga (Forbes) & & + & + & + & & & & & \\
\hline 51. & M. (M.) vagrans (Stoliczka) & & + & + & + & + & & $+?$ & $+?$ & \\
\hline 52. & M. (M.)? sp. & & & + & + & & & & & \\
\hline 53. & Caryocorbula minima (d'Orbigny) & & + & + & + & & & & & + \\
\hline 54. & Caryocorbula cauveriensis sp. nov. & & + & + & & & & & & \\
\hline 55. & Caestocorbula kubera sp. nov. & & + & + & & & & & & \\
\hline 56. & Lentidium (Janschinella) dissitum sp. nov. & & + & & & & & & & \\
\hline 57. & Hiatella tenella (Stoliczka) & & + & + & + & & & & & \\
\hline 58. & Xylophagella crassula (Stoliczka) & $+?$ & + & + & & & & & & \\
\hline 59. & Goniomya (G.) sp. & & + & & & & & & & \\
\hline 60. & Barcoona? gradilis sp. nov. & & + & + & & & & & & \\
\hline & Totals & $11 ?$ & 46 & 38 & 38 & $13 ?$ & $4 ?$ & $3 ?$ & $3 ?$ & $5 ?$ \\
\hline
\end{tabular}


Tröger 1989, Crame 1981). Previous records of $I .(I$. pictus from the Pondicherry Sub-basin (Karai and Kulakkalnattam Formations) are by Chiplonkar and Tapaswi (1974) and Ayyasami and Banerji (1984), the latter (Karai Formation only) associated with the ammonites Eucalycoceras pentagonum (JukesBrown and Hill) and Pseudocalycoceras harpax (Stoliczka) and consistent with a Middle to Late Cenomanian age.

Elsewhere in the Mediterran-Caucasian Realm extending from Europe to India-Madagascar, a Middle Cenomanian age is recognised for $I$. (I.) pictus (Heinz 1933, Kauffmann 1973, Tröeger 1989, Gale et al. 2002). From these limited and somewhat inconclusive data, we assign the Locality 3 material provisionally to the Middle to Late Cenomanian.

The distinctive Locality 2 assemblage, visibly dominated by the turritellid gastropod "Turritella" nodosa Roemer, is associated with a fine-textured, calcareous, sandy to silty sediment, consistent with the Odiyam Member of the Karai Formation, which has a time-range of Late Albian to Early Cenomanian, after Sundaram et al. (2001, fig. 5). One ammonite, Scaphites obliquus (J. Sowerby), has been obtained from Locality 2, a species with a time-range of Early to Middle Cenomanian (R.A. Henderson, personal communication, December 1998).

The bivalve assemblage from Locality 2 is the most speciose (46 species, Table 5) of the three from Odiyam; only four species, all either uncommon or rare, appear to be restricted to Locality 2. A comparison of the remaining 42 species (Locality 2) with the assemblages from Localities 1 and 3 shows that:

I. 18 (mostly common) species are present at Localities 1, 2 and 3:

II. 14 (some common) species are present only at Localities 1 and 2:

III. 8 (mostly uncommon to rare) species are present only at Localities 2 and 3 .

Thus the shared bivalve records and affinities are stronger between Localities 2 and 1 (Middle ? Cenomanian) than between Localities 3 (Late Cenomanian) and 2.

If our assignment of the Locality 2 material to the Odiyam Member is correct, then the above data and the presence of Scaphites obliquus would suggest a position high in that Member and thus probably of Early Cenomanian age (Sundaram et al. 2001, fig. 5). Table 5 summarises these conclusions. The respective age estimates (Early, Middle and Late Cenomanian) regarding the three Odiyam fossil localities, discussed above, are viewed as being provisional and subject to confirmation from further study. For this reason, ages for the study material in the following systematic descriptions are cited merely as undifferentiated Cenomanian.

\section{Palaeobiogeography}

By Albian-Cenomanian time, the fragmentation and dispersal of Gondwana was well advanced, with the island of proto-India-Madagascar located in temperate mid-latitudes of the Southern Hemisphere and near the northern end of the Mozambique Seaway, a major marine corridor that had opened up between south-east Africa and Antarctica-Australia (Westermann 2000: 62, fig. 2, Sundaram et al. 2001). According to Barron (1987), the separation of India-Madagascar was effected between the Late Albian and Late Turonian. The consequent Early to Middle Cretaceous reorganisation of oceanic circulation found the young Cauvery Basin in proximity to the boundary of both Austral and Mediterran-Caucasian Realms (terminology of Westermann 2000) and in direct, close exchange with major oceanic basins and seaways of the post-Gondwanan world. Within a broad embayment opening to the (modern) northeast, Uttattur Group sediments formed from the Late Albian to Early Turonian in a transgressive (Haq et al. 1987), passive margin environment under conditions of free oceanic exchange, as shown by their diverse assemblages of planktic foraminifers and ammonites (Sastry et al. 1968, Narayanan 1977, Ayyasami and Bannerji 1984, Ayyasami 1990, Venkatachalapathy and Ragothanam 1995).

Recognising the genus or subgenus as basic units in biogeographical evaluation (Kauffmann 1973), it is not surprising from the foregoing that a large majority of the bivalve genera or subgenera represented in the study material from the Karai

$$
\text { (Text continued p.12) }
$$

Table 6 Synopsis of bivalve genera/subgenera in the study material. Asterisk denotes first record from the Uttattur Group.

Subclass PROTOBRANCHIA: Nucula s. str., Leionucula*, Nuculana s. str.

Subclass PTERIOMORPHA: Noetiid*, genus and species undetermined, Grammatodon (Nanonavis), Nemodon s. str., Trigonarca (Costelliarca), Limopsis*, Glycymerita s. str., Inoceramus s. str., Pinna, Limatula, Plagiostoma, Pycnodonte, Plicatula (Darteplicatula*), Atreta*, Syncyclonema, Parvamussium*, Neithea s. str., Nippononectes*.

Subclass HETERODONTA: Callucinopsis?*, Callucinella*, Mesomiltha*, Paramyrtea* gen. nov., Fimbria*, Goodallia*, Eriphyla (Miyakoella*), Anthonya*, Protocardia s. str., Profragum, Pratulum*, Linearia*, Aenona ?*, Aphrodina s. str., Mesocallista s. str., Caryocorbula*, Caestocorbula*, Lentidium* (Janschinella*), Hiatella, Xylophagella*.

Subclass ANOMALODESMATA: Goniomya s. str.*

Family undetermined: Barcoona*. 
Table 7 Cretaceous occurrences of widely distributed non-cosmopolitan bivalve genera in the study material (Karai Formation). References: see below under Systematic Palaeontology.

\begin{tabular}{|c|c|c|}
\hline & Genera/subgenera & Occurrences \\
\hline 1. & Nanonavis & $\begin{array}{l}\text { W and C Europe, Russia, N Africa, Albian-Maastrichtian. Japan, Sakhalin, } \\
\text { Neocomian-Maastrichtian. Angola, SE Africa, Madagascar, Senonian. Australia, } \\
\text { Neocomian-Maastrichtian. India, Uttattur and Ariyalur Groups, Cenomanian- } \\
\text { Maastrichtian. }\end{array}$ \\
\hline 2. & Nemodons. str. & $\begin{array}{l}\text { N America, Texas, Maastrichtian. India, Uttattur and Trichinopoly Groups, } \\
\text { Cenomanian-Turonian. }\end{array}$ \\
\hline 3. & Glycymeritas. str. & $\begin{array}{l}\text { W Europe, Neocomian. S Pacific, Santonian-Pliocene. India, Uttatur, } \\
\text { Trichinopoly and Ariyalur Groups, Albian?, Cenomanian-Maastrichtian. }\end{array}$ \\
\hline 4. & Atreta & $\begin{array}{l}\text { Europe, Rhaetian, Lower Lias, Oxfordian, Albian-Maastrichtian. N America, } \\
\text { Senonian. Mozambique, Somalia, Madagascar, Albian, Maastrichtian. S Pacific, } \\
\text { Campanian? -Maastrichtian. W Australia, Santonian-Maastrichtian. India, } \\
\text { Uttattur Group, Cenomanian. }\end{array}$ \\
\hline 5. & Syncyclonema & $\begin{array}{l}\text { N America, Campanian-Maastrichtian. Europe, Aptian-Maastrichtian. Japan, } \\
\text { Aptian-Albian?. Australia, Neocomian-Aptian. India, Uttattur Group, } \\
\text { Cenomanian. }\end{array}$ \\
\hline 6. & Nippononectes & $\begin{array}{l}\text { Japan, Aptian-Maastrichtian. W Australia, Santonian-Maastrichtian. India, } \\
\text { Uttattur Group, Cenomanian. }\end{array}$ \\
\hline 7. & Callucinopsis? & $\begin{array}{l}\text { A qualified determination. The genus occurs in the "entire Indo-Mediterranean } \\
\text { region" (Kauffmann 1973: 361), Senonian. India, Uttattur Group, Cenomanian. }\end{array}$ \\
\hline 8. & Mesomiltha & $\begin{array}{l}\text { Widespread in north European province (Kauffmann 1973: 369). India, Uttattur } \\
\text { Group and Ariyalur Group, Cenomanian-Maastrichtian. }\end{array}$ \\
\hline 9. & Fimbria & $\begin{array}{l}\text { Among "widespread Pacific or trans-temperate bivalves ... common in east } \\
\text { African province" (Kauffmann 1973: 374). India, Uttattur Group, Cenomanian; } \\
\text { Ariyalur Group, Paleocene. }\end{array}$ \\
\hline 10. & Anthonya & $\begin{array}{l}\text { W Europe, Barremian-Albian. Japan, Aptian-Albian. New Zealand, Santonian- } \\
\text { Maastrichtian. S Africa, Lower Cretaceous. N America, Upper Cretaceous. India, } \\
\text { Uttattur Group, Albian-Cenomanian. }\end{array}$ \\
\hline 11. & Goodallia & N Europe, N America, Miocene-Recent. India, Uttattur Group, Cenomanian. \\
\hline 12. & Miyakoella & $\begin{array}{l}\text { N Japan, Aptian-Albian. E Africa, Neocomian. Argentina, Neocomian. India, } \\
\text { Uttattur Group, Albian-Cenomanian. }\end{array}$ \\
\hline 13. & Protocardia & $\begin{array}{l}\text { Europe, Neocomian-Turonian. N Africa, Cenomanian-Turonian. W Africa, } \\
\text { Maastrichtian. S Pacific, Aptian-Maastrichtian?. India, Bagh Beds, Turonian; } \\
\text { Uttattur, Trichinopoly and Ariyalur Groups, Albian?, Cenomanian- } \\
\text { Maastrichtian. }\end{array}$ \\
\hline 14. & Profragum & $\begin{array}{l}\text { W Africa, Cretaceous. New Caledonia?, Late Cretaceous. India, Uttattur and } \\
\text { Trichinopoly Groups, Cenomanian-Turonian. }\end{array}$ \\
\hline 15. & Pratulum & $\begin{array}{l}\text { "Euramerica and the Austral province" (Kauffmann 1973: 359-372). N Australia, } \\
\text { Cenomanian. India, Uttattur and Trichinopoly Groups, Cenomanian-Turonian. } \\
\text { Madagascar, Maastrichtian. }\end{array}$ \\
\hline 16. & Linearia & $\begin{array}{l}\text { N America, Lower-Upper Cretaceous. India, Uttattur, Trichinopoly and } \\
\text { Ariyalur Groups, Cenomanian-Campanian (or Maastrichtian). }\end{array}$ \\
\hline 17. & Aenona? & $\begin{array}{l}\text { A qualified determination. N America, Maastrichtian. India, Uttattur and } \\
\text { Trichinopoly? Groups, Cenomanian-Turonian?. }\end{array}$ \\
\hline 18. & Aphrodinas. str. & $\begin{array}{l}\text { N America, Late Cretaceous. India, Uttattur, Trichinopoly and Ariyalur Groups, } \\
\text { Cenomanian-Maastrichtian. }\end{array}$ \\
\hline 19. & Mesocallista s. str. & $\begin{array}{l}\text { W and S Africa, Europe, W South America, Late Cretaceous. India, Uttattur, } \\
\text { Trichinopoly and Ariyalur Groups, Cenomanian-Santonian/Campanian. }\end{array}$ \\
\hline 20. & Caryocorbula (Cretaceous only) & $\begin{array}{l}\text { W Europe, Albian-Campanian. S Pacific, Santonian-Maastrichtian. N Australia, } \\
\text { Cenomanian. W North America, Aptian-Maastrichtian. India, Uttattur Group, } \\
\text { Cenomanian; Ariyalur Group, Maastrichtian. }\end{array}$ \\
\hline 21. & Caestocorbulas. str. & $\begin{array}{l}\text { Japan, Lower Cretaceous and Cenomanian. W North America, Aptian-Turonian. } \\
\text { India, Uttattur Group, Cenomanian. }\end{array}$ \\
\hline 22. & Hiatella & Asia, Europe, N America, India, Uttattur Group, all Cenomanian. \\
\hline 23. & Xylophagella & $\begin{array}{l}\text { N America, Barremian? or early Albian-Maastrichtian. India, Uttattur Group, } \\
\text { Albian?-Cenomanian. }\end{array}$ \\
\hline
\end{tabular}


Formation are either cosmopolitan in character or are widely distributed in both Austral and Mediterran-Caucasian Realms of both hemispheres. A similar conclusion for the biogeographic character of the entire south Indian Cretaceous was reached by Chiplonkar and Tapaswi (1979). An endemic element in the assemblage, defined as that apparently confined to the Cauvery Basin, if confirmed, would comprise a small minority of genera, not exceeding $5 \%$ of the total. This may exemplify the marked reduction in bivalve endemicity that accompanied the AlbianCenomanian transgression, noted by Kauffmann (1973: 369, 371, figs 4, 5).

A literature search (see Table 2) has shown that hitherto 102 species of Bivalvia have been recorded from the Uttattur Group, of which 20 are also included in the present study, which comprises 60 species. Thus, a new provisional total of Uttattur bivalves comes to 142 species. Any definitive account of Uttattur bivalve palaeobiogeography would require evaluation of the entire assemblage, but only after taxonomic revision, something beyond the ambit of this study. Our results, based on limited collections from one small area, are less than representative of the total Karai bivalve fauna, but may be viewed as a contribution toward a future, more comprehensive study. The 60 species in the study material have been assigned to 41 genera, of which 25 genera/subgenera are here recorded from the Uttattur Group for the first time.

According to Kauffmann (1973: 358-359), 12 of the above 43 genera/subgenera (28\%) were cosmopolitan in distribution "during the Cretaceous". These are Nucula s. str., Leionucula, Nuculana s. str., Limopsis, Parvamussium, Neithea s. str., Limatula, Plagiostoma, Inoceramus s. str., Pycnodonte, Pinna and Goniomya. Noteworthy from this group of cosmopolitan genera is the absence of the subclass Heterodonta. Caestocorbula s. str. is among genera said to be characteristic of Kauffmann's (Cretaceous) North Temperate Realm (Kauffmann 1973: 367, Squires and Saul 2004: 120).
Its evident presence in the Karai Formation would enlarge on that distribution.

Of the remaining 31 genera/subgenera, 23 present wide to very wide, near-cosmopolitan distributions during the Cretaceous. Non-Indian records are typically from the Austral and MediterranCaucasian Realms of Westermann (2000), with representation in Australia, $\mathrm{N}$ America, Europe, Africa, Madagascar and Japan. These, combined with the above listed, fully cosmopolitan taxa, together constitute about $80 \%$ of the total generic representation in the study material.

Other genera/subgenera represented in the study material, neither cosmopolitan nor widely distributed, as above, and of constrained or unknown Cretaceous distributions, are discussed below.

1. Costelliarca. W and S Africa, Madagascar. India, Uttattur, Trichinopoly and Ariyalur Groups, Cenomanian-Maastrichtian. These records all lie within adjacent areas of the Mediterran-Caucasian and Austral Realms of Westermann (2000).

2. Darteplicatula. First pre-Tertiary record (see Hertlein in Moore 1969: N379).

3. Callucinella. First pre-Tertiary record (see Chavan in Moore 1969: N498-N499).

4. Paramyrtea gen. nov. Possibly endemic to Cauvery Basin.

5. Lentidium (Janschinella). First pre-Tertiary records of genus and subgenus (see Newell in Moore 1969: N696, N697).

6. Barcoona ?. Provisional determination: first record beyond type area (Aptian-Albian, $\mathrm{N}$ Australia).

\section{Predation}

Evidence for predation of bivalves in the study material comes from the occasional presence of gastropod boreholes, recognised in 10 of the 60 species to hand (Table 8) and drawn from each of the three Odiyam localities. The majority of these are of the bevelled or countersunk type, usually

Table 8 Predation of bivalves from the Karai Formation at Odiyam, indicated by gastropod boreholes. Species in order of predation frequency.

\begin{tabular}{llccc}
\hline \multicolumn{1}{c}{ Species } & $\begin{array}{c}\text { Total } \\
\text { specimens }\end{array}$ & $\begin{array}{c}\text { No. } \\
\text { bored }\end{array}$ & $\begin{array}{c}\% \\
\text { bored }\end{array}$ \\
\hline 1. Paramyrtea sabulosa gen. nov., sp. nov. & 445 & 58 & 13.0 & Naticiform and other. \\
2. Barcoona ? gradilis sp. nov. & 45 & 4 & 8.9 & Other. \\
3. Pycnodonte vesiculosa (J. Sowerby) & 103 & 9 & 8.7 & Naticiform and other. 8LVs, 1RV. \\
4. Caryocorbula minima (d'Orbigny) & 268 & 16 & 6.0 & Naticiform and other. 4LVs, 12RVs. \\
5. Trigonarca (Costelliarca) gamana (Forbes) & 21 & 1 & 4.8 & Naticiform. \\
6. Mesocallista (M.) vagrans (Stoliczka) & 33 & 1 & 3.0 & Naticiform. \\
7. Grammatodon (Nanonavis) subcrenulatus sp. nov.149 & 4 & 2.7 & Naticiform and other. & Other. \\
8. Parvamussium sp. & 48 & 1 & 1 & Other. \\
9. Limopsis coemansi Briart and Cornet & 184 & 1 & 0.5 & Naticiform. \\
10. Nuculana (N.) odiyamensis sp. nov. & &
\end{tabular}


Table 9 Locality names. In the geological and palaeontological literature of the Cauvery Basin, extending back over the past 150 years, English language spellings of locality and other names have varied according to times and authors. Renditions adopted herein reflect current usage and are listed with equivalents from earlier sources.

\begin{tabular}{|c|c|}
\hline This paper & Previous formulations from other sources \\
\hline Alandalippur & Alundanopuram, Alundanapooram, Alundalippur, Alundaluipur. \\
\hline Anaipadi & Anapaudy. \\
\hline Ariyalur & Ariyaloor, Arrialoor. \\
\hline Cauvery River/Basin & Kaveri. \\
\hline Coomarapolliam & Comarapolliam. \\
\hline Garudamangalam & Garudamangalum, Garudamungalum. \\
\hline Kallakudi & Kallakkudi. \\
\hline Kallakurichchi & Kallankurichchi. \\
\hline Karapadi & Karrapaudy, Karapaudy, Karappadi. \\
\hline Kolkata & Calcutta. \\
\hline Kulakkalnattam & Kolukonuttom. \\
\hline Kunnam & Coonum. \\
\hline Mallur & Mulloor. \\
\hline Maruvattur & Moraviatoor, Mooraviatoor. \\
\hline Mungalpari & Monglepaudy, Mungilpadi. \\
\hline Narmada River & Nerbuddha. \\
\hline Niniyur & Niniyoor, Ninyoor, Ninnyoor. \\
\hline Odiyam & Odium, Odiam. \\
\hline Paravay & Puravoy. \\
\hline Pondicherry & Pondicherri. \\
\hline Pudur & Poodoor, Poothoor, Poothur. \\
\hline Pune & Poona. \\
\hline Saradamangalam & Serdamungalum, Saradamangalan, Serdamangalam. \\
\hline Tiruchirapalli & Trichinopoly, Trichinopoli, Trinchinopoly. \\
\hline Uttattur & Ootatoor, Utatur, Uttatur. \\
\hline Valudavur & Valudayur. \\
\hline Vriddhachalam & Verdachellum, Vridhachalam. \\
\hline
\end{tabular}

attributed to the carnivorous Naticidae; others are of non-bevelled or uncertain configuration (e.g. viewed from the interior of a valve only) and possibly made by muricoideans and/or some other epifaunal gastropod group (Kabat 1990 and references). Harper and Peck (2003) have recently reported both countersunk and other borehole morphologies in shelled prey, all made by one species of modern Antarctic muricid gastropod. Naticids are active, infaunal, carnivorous snails associated with fine, soft substrates, and which prey on bivalves and other, mainly infaunal, molluscs. In the Karai Formation, two naticid species are common, the smaller Euspira spissata Stoliczka, the larger Gyrodes pansus Stoliczka, and these are presumed to be among the responsible predators.

Of the 91 examples of gastropod boreholes listed below (Table 8), 86 were singles, two had been bored twice and two others bored three times, of which one attempt had been unsuccessful; another showed three attempted boreholes, none successful. It is noteworthy that two prey species, a lucinid and a corbulid, together account for over $80 \%$ of all borings. The former of these, Paramyrtea sabulosa gen. nov., sp. nov., is the most strongly sculptured of the infaunal prey species, perhaps in response to gastropod predation such as this. Noteworthy for their low rates of gastropod predation are the common Limopsis coemansi Briart and Cornet and Nuculana (N.) odiyamensis sp. nov., both presumed to be of infaunal burrowing habit.

\section{SYSTEMATIC PALAEONTOLOGY}

Class Bivalvia Linnaeus, 1758

Subclass Protobranchia Pelseneer, 1889

Order Nuculoida Dall, 1889

Superfamily Nuculoidea Gray, 1824

Family Nuculidae Gray, 1824

Genus Nucula Lamarck, 1799

Type species

Arca nucleus Linnaeus, 1758, by monotypy. Recent, North Atlantic.

Subgenus Nucula s. str

Nucula (Nucula) bidorsata Stoliczka, 1871

Figure 2A, B

1871 Nucula bidorsata Stoliczka: 329 , pl. 17, figs 22, 24-27. 
1987 Nucula bidorsata Stoliczka; Tapaswi: 506. List only.

\section{Material examined}

\section{Lectotype}

Here designated. GSI Stoliczka Collection 1180, conjoined valves with $\mathrm{LV}$ and posterior part of RV intact, from "Moraviatoor" (=Maruvattur).

\section{Paralectotypes}

GSI Stoliczka Collection 1178, 1181, 1182, four internal moulds, two with shell remnants. Total of five specimens, all from type locality. See Remarks.

\section{Other material}

ARI G2681, two LVs, one RV, Odiyam Locality 1; G2759, 32 single valves ( $10 \mathrm{LVs}, 22 \mathrm{RVs}$, mostly decorticated, six interiors), 20 internal moulds (13 LVs, seven RVs) and two conjoined pairs (one internal mould, one with shell remnants), Odiyam Locality 2; G2874, two LVs, Odiyam Locality 3; G2929, two LVs, one RV, Odiyam Locality 3. Total of 62 specimens (plus type material).

\section{Diagnosis}

Small, length to $5 \mathrm{~mm}$, sculpture initially radial, becoming finely cancellate; posterior area small, shallow.

\section{Description}

Small, length to $5 \mathrm{~mm}$, fragile, transversely subovate; extended anteriorly, short and roundly truncate posteriorly; area offset from disc by radial angulation; inflation moderate; beaks at posterior third, opisthogyrate; prodissoconch smooth; umbones initially smooth, after ca 0.8 $\mathrm{mm}$ of growth develop very fine, close, radial costellae of increasing strength, about as wide as interspaces; radials followed by very fine and more widely spaced, commarginal threads which (in unworn specimens) pass over costellae, otherwise confined to intercostal spaces; commarginal threads occasionally anastomose, number ca 30 in height of $4.25 \mathrm{~mm}$; radials ca 50 , extending into middle layer of shell, their truncation along ventral margin corresponding to fine, interlocking crenulae; posterior area small, shallowly recessed, bordered by weak posteroventral shoulder and bearing ca seven fine, radial threads; escutcheon short, smooth, weakly defined; lunule lanceolate; interior nacreous; adductor scars (from internal moulds) weakly impressed, posterior more evident, roundly subquadrate and centred slightly above plane of maximum length; pallial line not discernible; hinge taxodont, anterior series much the larger, otherwise poorly exposed.
Dimensions of Nucula (Nucula) bidorsata Stoliczka.

\begin{tabular}{lccc}
\hline Specimens & Length & Height & Inflation \\
\hline GSI 1180, pair, lectotype & 4.16 & 3.12 & 1.96 \\
ARI G2759/1 RV & 5.25 & 4.04 & 0.85 \\
\hline
\end{tabular}

\section{Remarks}

Nucula bidorsata was described from "Moraviatoor [=Maruvattur], in dark earthy limestone. Ootatoor Group" (Stoliczka 1871), probably from the upper limestone unit of the Dalmiapuram Formation of Late Albian age (Sundaram et al. 2001). A combined lot of this species from the GSI Stoliczka Collection comprises the following five specimens, none individually numbered:

(i) paired valves retaining intact $L V$ and posterior half of RV;

(ii) internal mould of pair, retaining part of $L V$;

(iii) internal mould of crushed LV, retaining shell remnants;

(iv, v) two internal moulds, one of LV, other of uncertain orientation.

Of these specimens the first listed is by far the best preserved and is assigned GSI No. 1180 and is here designated lectotype of the present species; the other four specimens are therefore paralectotypes.

The above five specimens are accompanied by labels with the following particulars:

"1178 Nucula bidorsata Stoliczka. Moraviatoor, Uttattur Group, pl. xvii, fig. 22"

"1180 Nucula bidorsata Stoliczka. Moraviatoor, Uttattur Group, pl. xvii, fig. 24, 24a"

"1181 Nucula bidorsata Stoliczka. Moraviatoor, Uttattur Group, pl. xvii, fig. 25"

"1182 Nucula bidorsata Stoliczka. Moraviatoor, Uttattur Group, pl. xvii, fig. 26"

With these is a fifth label which reads, "1179 Nucula crassicula Stoliczka, Karrapaudy, Ariyalur Group, fig'd pl. 17, figs 23, 23a, 23b". Specimen 1179 has not been located.

Stoliczka's figures 22 and 26 depict two LV interiors. Fig. 24 shows the LV of "a perfect specimen", fig. 25 shows the LV (not RV as the caption reads) of a decorticated "perfect specimen" and fig. 27, omitted from the captions, depicts a well-preserved conjoined pair. Comparing Stoliczka's figures and captions with the GSI specimens cited above, leaves considerable doubt as to whether the original figured specimens are present among this material. However, repeated searches of the Stoliczka Collection at Kolkata have failed to locate any other material of this species and, despite their mostly poor preservation, the above specimens would appear to be part at least of Stoliczka's original material. The best-preserved specimen, designated lectotype, agrees well with the description and external figures of Nucula 
bidorsata. Odiyam specimens are identical with the lectotype and paralectotypes.

Stoliczka (1871 p. 330) noted the tendency of specimens of Nucula bidorsata to decorticate, exposing "the inner, thin, pearly layer, which is radiately striated externally and smooth internally". His fig. 25 illustrates such a specimen. The ribs of this internal structure are flat with linear interspaces and, except for weak growth striae, lack any commarginal component (fig. 2B). Both cancellate and radial sculpture are occasionally found on a single specimen, the latter a consequence of partial decortication. Though common, preservation is usually poor due to the brittle nature of the shell.

In the cancellate sculpture of the natural surface, the present species, through much finer, shows some resemblance to Nucula pectinata J. Sowerby, type species of the subgenus Pectinucula Quenstedt, 1930, which occurs widely throughout the Albian of Europe and North Africa (Woods 1899: 16-18, pl. 2, figs 22-27; Mongin 1979: 419). Differences include the rather more emphatic radials, more strongly defined, cardiform posterior area and much greater size (up to $30 \mathrm{~mm}$ length) of $N$. pectinata: unlike the present species, the adductor scars are deeply recessed and we recognise no close taxonomic affinity between the two species.

Closer to the present species is Nucula kaffraria Rennie from the Senonian (Upper Campanian ?) of Pondoland (Rennie 1930: 168, pl. 16, figs 2-5), differing in minor sculptural features and a more prominent escutcheon (" "lunule" of Rennie 1930). Rennie compared his species with $N$. pulvillus Müller from the Campanian of Aachen. Judging from the figures in Speden (1970: 29-31, pl. 1, figs 1-11), N. cancellata Meek and Hayden, from the Maastrichtian Fox Hills Formation of South Dakota, much resembles the present species in shape and sculpture.

\section{Occurrence}

Uttattur Group. Maruvattur (type). Dalmiapuram Formation. Late Albian. Odiyam Localities 1, 2 (common) and 3. Karai Formation (Odiyam and Kunnam Members). Cenomanian.

\section{Genus Leionucula Quenstedt, 1930}

Ennucula Iredale, 1931.

\section{Type species}

Nucula albensis d'Orbigny, 1844, by original designation. Albian, Europe.

\section{Leionucula sp. cf. L. albensis (d'Orbigny, 1844)} Figure $2 \mathrm{C}$ cf. 1844 Nucula albensis d'Orbigny: 172, pl. 301, figs 15-17.

cf. 1899 Nucula albensis d'Orbigny; Woods: 24, 25, pl. 4, figs 9-17.

cf. 1979 Nucula (Leionucula) albensis d'Orbigny; Mongin: 415.

\section{Material examined}

ARI G2682, one conjoined pair, two LVs, one RV, all decorticated, Locality 1; G2760, four RV exteriors, one complete; one $\mathrm{LV}$ interior, incomplete, Locality 2; G2875, one LV internal mould, two fragments of uncertain orientation, Locality 3 . Total of 12 specimens.

\section{Description}

Small for subgenus, length to $13 \mathrm{~mm}$, robust, internally nacreous; longer than high, ovate; posterior short, obliquely truncated; anteriorly extended, antero-dorsal margin gently convex; anterior area lanceolate, offset from disc by faint radial angulation; posterior area small, bordered by well-rounded shoulder; umbones broadly inflated, low, opisthogyrate; beaks incurved at posterior third; exterior polished, smooth except for few weak growth striae; adductor scars lightly impressed, anterior apparently larger; hinge nuculoid, anterior series much the larger, other details not discernible; ventral margin not crenulate, reflecting absence of internal radial structure.

Dimensions of Leionucula sp. cf. L. albensis (d'Orbigny).

\begin{tabular}{lccc}
\hline Specimens & Length & Height & Inflation \\
\hline $\begin{array}{l}\text { ARI G2682/1 LV } \\
\quad \text { decorticated) }\end{array}$ & 12.81 & 9.38 & 3.27 \\
$\begin{array}{l}\text { ARI G2760/1 RV } \\
\quad \text { (part-decorticated) }\end{array}$ & 10.15 & 7.42 & 2.85 (est.) \\
ARI G2760/4 RV & 8.12 & 5.91 & 1.50 \\
\hline
\end{tabular}

\section{Remarks}

The study material is very similar to Leionucula albensis (d'Orbigny), which is widely distributed in the Albian of Europe and possibly also in the Cenomanian and Turonian of England (Woods 1899, Mongin 1979, tab. 91 ). On the Odiyam specimens, details of the lunule, escutcheon, dentition and other internal characters are obscured and further determination is deferred until better material is available. $L$. albensis varies considerably in proportions according to Woods, and attains a larger size than the present specimens. This is the first record of the genus from the Cretaceous of south India. The extant type material of Nucula albensis d'Orbigny and the relationship of Leionucula Quensted to 

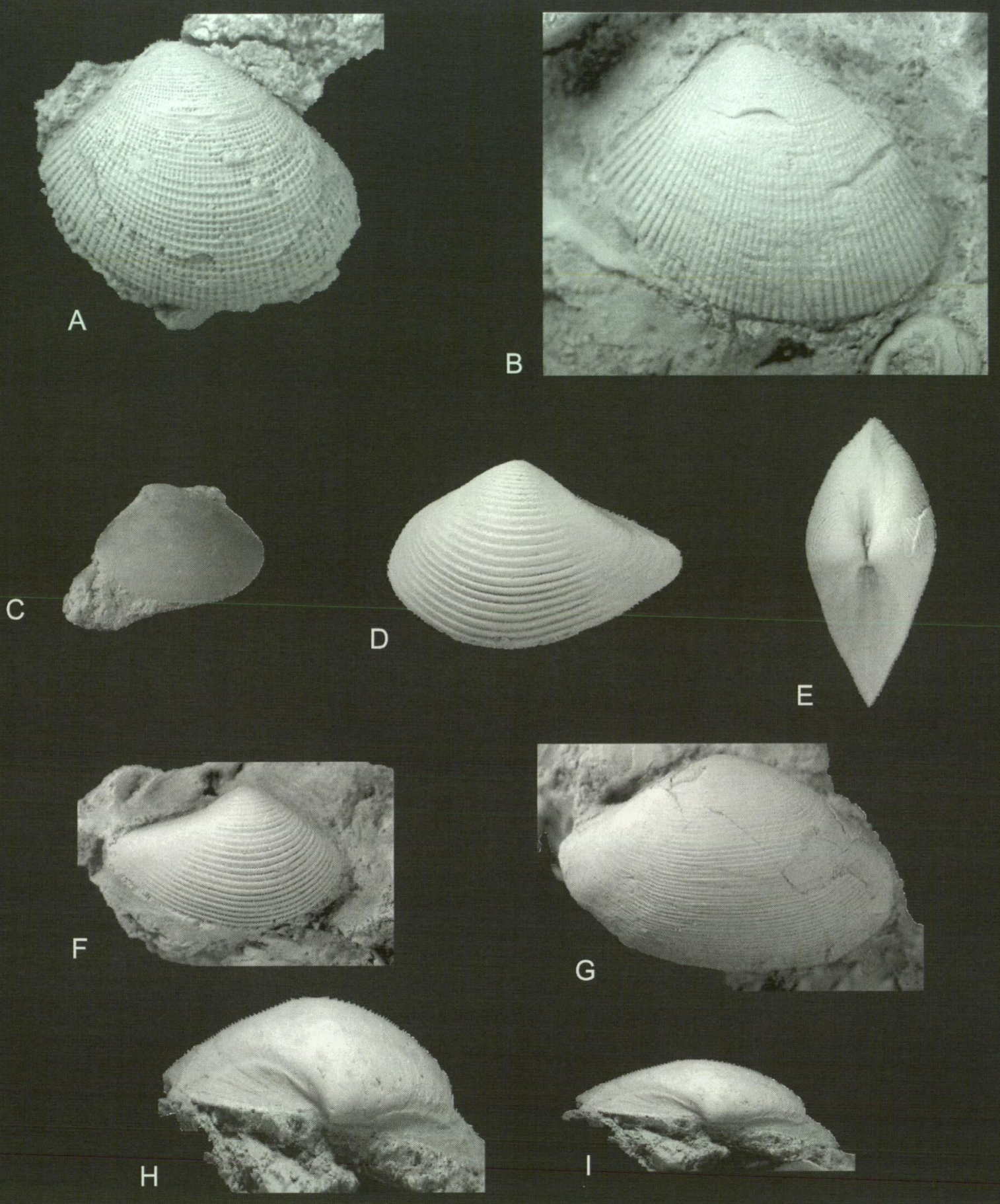

Figure 2 Nucula (N.) bidorsata Stoliczka. A ARI G2759/1, RV with natural exterior x 8. B ARI G2759/2, RV with decorticated exterior x 10. Leionucula sp. cf. L. albensis (d'Orbigny). C ARI G2760/4, RV external x 3. Nuculana (N.) odiyamensis sp. nov. D, E ARI G2761/7, holotype, conjoined valves, LV external and dorsal aspects, both x 6. F ARI G2761/6, paratype, RV external x 5. Nuculana (N.) arenicola sp. nov. G ARI G2838/5, holotype, RV external x 4. H, I ARI G2838/2, paratype, LV external x 4 and dorsal aspects x 3.

Ennucula Iredale were discussed by Stilwell (1993: 362, 363). The present species is rather more elongate than the Nucula sp. of Stoliczka (1871: 329, pl. 17, fig. 20), represented by an internal mould from Odiyam, and indicates a third nuculid species from the Uttattur Group.

\section{Occurrence}

Uttattur Group. Odiyam Localities 1, 2 and 3.
Karai Formation (Odiyam and Kunnam Members). Cenomanian.

Superfamily Nuculanoidea H. and A. Adams, 1858

Family Nuculanidae H. and A. Adams, 1858

Genus Nuculana Link, 1807 


\section{Type species}

Arca rostrata Chemnitz, 1774 (junior synonym of Arca pernula Müller, 1771). Recent, N Atlantic.

\section{Subgenus Nuculana s. str}

\section{Nuculana (Nuculana) odiyamensis sp. nov.} Figure 2 D-F

\section{Material examined}

\section{Holotype}

ARI G2761/7, paired valves, from brown calcareous siltstone with abundant turritellid gastropods, beside track ca $0.5 \mathrm{~km}$ west of Odiyam village, Perambalur Taluk, Tiruchirapalli district, Tamil Nadu (Locality 2).

\section{Paratypes}

ARI G2761/1-6, 8-19, eight LVs, 10 RVs and eight paired valves, all from type locality. Total of 27 specimens.

\section{Other material}

ARI G2683, five LVs, nine RVs, Locality 1. G2761, $66 \mathrm{LVs}, 62 \mathrm{RVs}, 25$ pairs (many incomplete) from Locality 2. Total of 167 specimens (plus type material).

\section{Diagnosis}

Small for genus, extended and horizontally rostrate posteriorly; sculpture of ca 26 commarginal costellae, narrower than interspaces, in height of 4.7 $\mathrm{mm}$; beaks, anterior slope and posterior fifth smooth; posterior area broadly lanceolate, bordered by rounded shoulders.

\section{Description}

Small for subgenus, length to $8 \mathrm{~mm}$, thin, fragile, longer than high; anteriorly short, rounded and tumid; posteriorly extended, compressed, rostrate, the extremity directed horizontally; umbones inflated, maximum inflation slightly anterior of beaks; beaks smooth, incurved, proximate, opisthogyrate, just anterior of centre; antero-dorsal margin slightly convex to almost straight, descending to short, rounded anterior margin; postero-dorsal margin slightly concave, extending to rostrate posterior extremity; ventral margin broadly rounded; lunular area smooth, weakly defined by rounded shoulders; posterior area larger, broadly lanceolate, shallowly excavate, smooth, bordered by rounded to weakly carinate shoulders; sculpture of regular, well-defined, commarginal costellae, narrower than interspaces, of variable density and extending from anterior shoulders to posterior fifth; costellae appear at ca $1.7 \mathrm{~mm}$ from beak, numbering 23-32 in height of $3.4-4.9 \mathrm{~mm}$; resilifer present (usually obscured); hinge nuculanoid, on narrow hinge plate, posterior series the greater; dentition occasionally discernible through dorsal margin but precise tooth counts indeterminable on present material; adductor scars (from moulds) lightly impressed, faint, anterior roundly subreniform, posterior larger, radially extended; pallial configuration obscure.

\section{Remarks}

Variation in the present species is seen mainly in the number, spacing and strength of the costellae, particularly in their persistence toward the beaks; the posterior fifth and anterior slope are invariably smooth. The species somewhat resembles and may be descended from Nuculana socialis Stoliczka from the Dalmiapuram Formation (Upper Albian) of Maruvattur (Stoliczka 1871: 323, pl. 17, fig. 13), differing in its stronger sculpture, which extends well beyond the median area of the disc.

The type material of Nuculana socialis Stoliczka bears no. 1170 in the Stoliczka Collection, Geological Survey of India, Kolkata. It comprises three conjoined pairs, the largest of which measures L $4.50 \mathrm{~mm}$, Ht $2.90 \mathrm{~mm}$, Inf. $2.26 \mathrm{~mm}$ and is here designated lectotype. Nuculana odiyamensis sp. nov. differs from $N$. (N.) arenicola sp. nov, in its fewer, more spaced costellae, beaks anterior of centre, weaker lunule and escutcheon and smaller size. The present species is very common in the Karai Formation at Odiyam Locality 2, from where about one specimen in six is a conjoined pair. One specimen only (paratype G2671/8) in the study material shows a naticiform gastropod borehole, indicating a low predation level from that source.

Dimensions of Nuculana (Nuculana) odiyamensis sp. nov.

\begin{tabular}{lcccc}
\hline Specimens & Length & Height & Inflation & Costellae \\
ARI G2761/7, pair, holotype & 7.48 & 4.87 & 3.23 & 26 \\
ARI G2761/1, LV, paratype & 7.68 & 4.70 & 1.5 (est.) & 25 \\
ARI G2761/2, LV, paratype & 5.37 & 3.35 & -24 & 24 \\
ARI G2761/3, LV, paratype & 6.85 & 4.19 & 1.7 (est.) & 1.4 (est.) \\
ARI G2761/4, RV, paratype & 6.55 & 4.04 & $3.93($ est.) & 27 \\
ARI G2761/5, RV, paratype & 6.41 & 4.22 & 1.6 (est.) & 26 \\
ARI G2761/6, RV, paratype & 7.07 & 4.60 & 1.8 (est.) & 32 \\
ARI G2761/15, LV, paratype & 7.37 & & \\
\hline
\end{tabular}




\section{Etymology}

From that of Odiyam village, the type area, where the species is very common.

\section{Occurrence}

Uttattur Group. Odiyam Localities 1 and 2 (type). Karai Formation (Odiyam and Kunnam Members). Cenomanian.

\section{Nuculana (Nuculana) arenicola sp. nov. Figure $2 \mathrm{G}-\mathrm{I}$}

\section{Material examined}

\section{Holotype}

ARI G2838/5, RV, from brown calcareous siltstone with abundant turritellid gastropods, beside track ca $0.5 \mathrm{~km}$ west of Odiyam village, Perambalur Taluk, Tiruchirapalli district, Tamil Nadu (Locality 2).

\section{Paratypes}

ARI G2838/1-4, 6-8, two LVs, five RVs, from type locality. G2876/1, LV, Locality 3. Total of nine specimens.

\section{Other material}

ARI G2684, three LVs, two RVs, Locality 1. G2685, two LVs, three RVs, two conjoined pairs (juvenile), Locality 1. G2961, one RV, Locality 1. G2992, two LVs, Locality 1. G2980, one RV, Locality 3. G2994, one LV, two RVs, Locality 3. Total of 19 specimens (plus type material).

\section{Diagnosis}

Medium size for genus, robust, length to $12 \mathrm{~mm}$, inflated, posterior moderately rostrate, beaks median, blunt; ca 60 slightly irregular, crowded, commarginal costellae in height of $7 \mathrm{~mm}$; lunule and escutcheon well defined.

\section{Description}

Medium-sized, robust, longer than high, moderately rostrate posteriorly; beaks median, blunt, incurved, smooth, opisthogyrate; umbones broadly inflated, moderately elevated; lunule lanceolate, extended, slightly excavate, bordered by thin radial threads and rounded shoulders; escutcheon broader, lanceolate, bordered by rounded shoulders and faint, shallow grooves; antero-dorsal margin slightly convex; posterodorsal margin slightly concave; dorsal margins together subtending angle of ca $115^{\circ}$; anterior margin short, rounded; posterior margin rostrate, extremity directed horizontally; ventral margin broadly rounded; sculpture of fine, crowded, low, commarginal costellae, slightly uneven in strength and spacing, occasionally anastomosing, about 60 in height of $7 \mathrm{~mm}$, becoming obsolete posteriorly; hinge mostly obscured, occasionally seen to be nuculanoid, posterior series slightly exceeding in number anterior (G2685, juvenile); other internal characters unknown.

Dimensions of Nuculana (N.) arenicola sp. nov.

\begin{tabular}{lccc}
\hline Specimens & Length & Height & Inflation \\
\hline ARI G2838/5, RV, holotype & $12.2^{*}$ & 7.91 & 3.0 (est.) \\
ARI G2838/1, RV, paratype & 9.47 & 5.96 & 1.9 (est.) \\
ARI G2838/2, LV, paratype & 11.35 & 7.20 & 2.6 (est.) \\
ARI G2838/4, RV, paratype & $* *$ & 8.62 & 2.7 (est.) \\
ARI G2838/6, RV, paratype & 7.10 & 4.38 & 1.6 (est.) \\
ARI G2876/1, LV, paratype & 5.28 & 3.42 & - \\
\hline
\end{tabular}

* estimate, slightly damaged at each end

** broken posteriorly

\section{Remarks}

The study material is at best marginally adequate for description and naming but taken together substantiates the presence of a second Nuculana species at Odiyam. The holotype is damaged at each end but otherwise indicates the dorsal configuration, sculpture and size, which distinguish the species from the associated $N$. (N.) odiyamensis sp. nov. Compared with that species, $N$. (N.) arenicola sp. nov. is less rostrate, with median, obtuse beaks, better defined areas, more crowded sculpture and greater size.

\section{Etymology}

Combines the Latin arena, sand and -cola, inhabitant, from the occurrence of the species in a sandy lithofacies.

\section{Occurrence}

Uttattur Group. Odiyam Localities 1, 2 (type) and 3. Karai Formation (Odiyam and Kunnam Members). Cenomanian.

\section{Subclass Pteriomorpha Beurlen, 1944}

Order Arcoida Stoliczka, 1871

Superfamily Arcoidea Lamarck, 1809

Family Noetiidae Stewart, 1930

\section{Subfamily Striarcinae Macneil, 1938}

Noetiid, genus and species undetermined Figure 3A-D

\section{Material examined}

ARI G2882, seven RVs, one LV, one LV internal mould, Locality 3 . Total of 9 single valves.

\section{Description}

Small, longer than high, thin-shelled, fragile; 

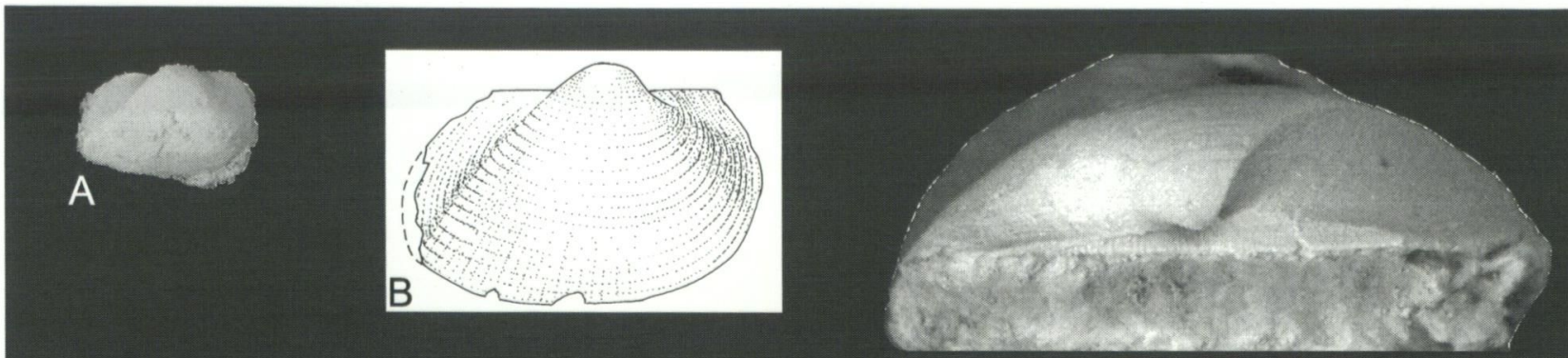

C
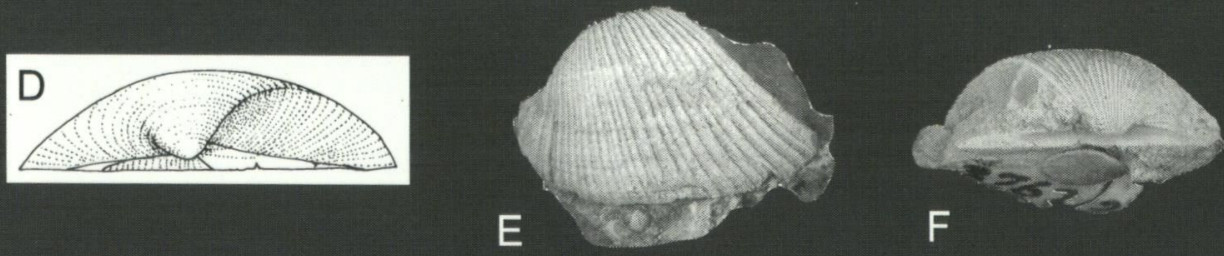

F

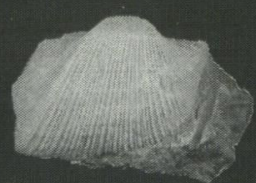

G
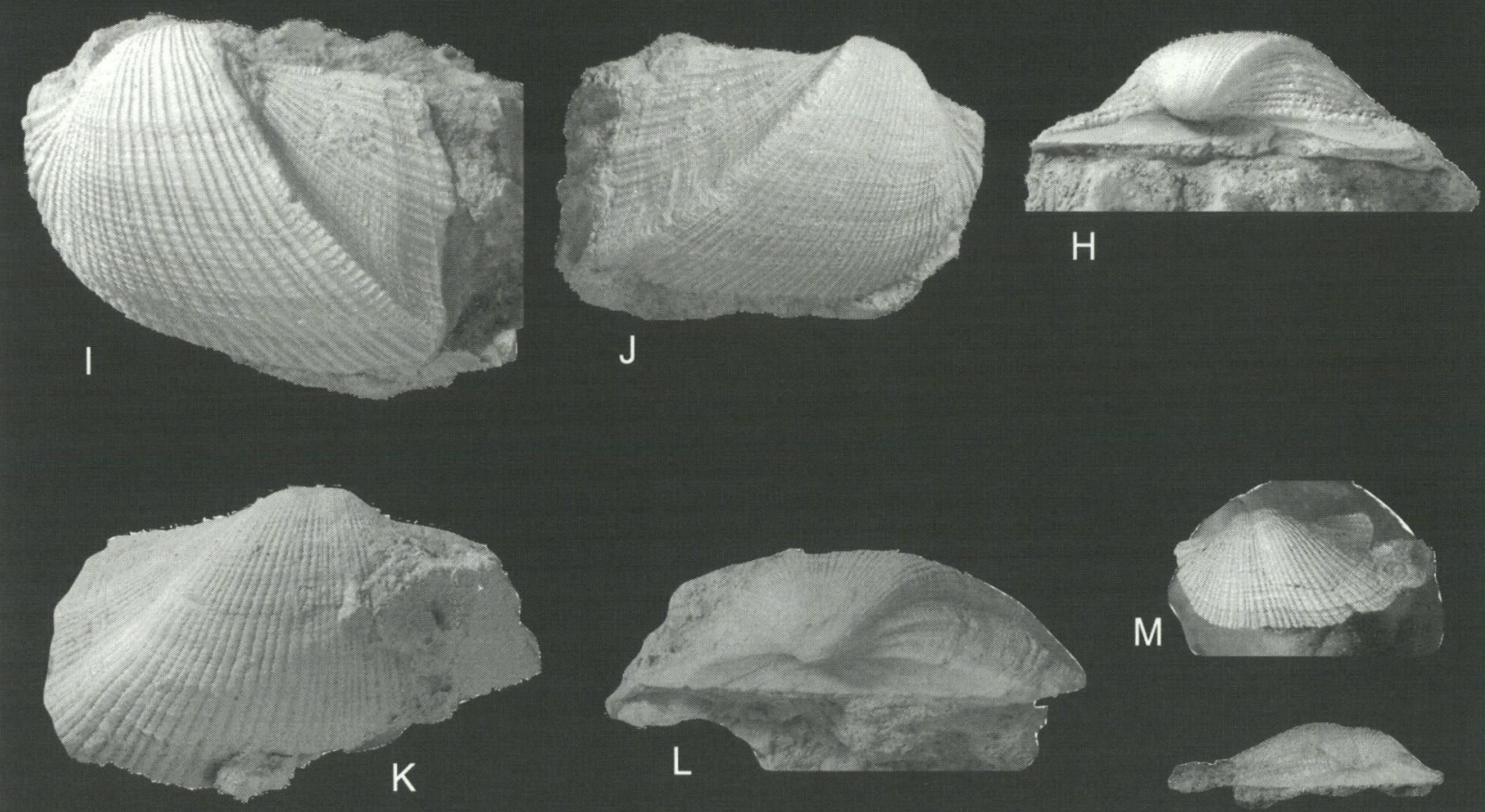

$\mathrm{H}$

M

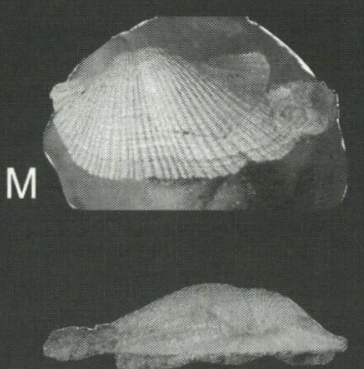

N

Figure 3 Noetiid, genus and species undetermined. ARI G2882/1, RV. A external x 2 and B drawing x 4 . C dorsal aspect $\times 7.3$ and D drawing x 4. Grammatodon (Nanonavis) subcrenulatus sp. nov. E, F ARI G2762/2, holotype, LV external x 1.5 and dorsal x 2.5. G, H ARI G2762/6, paratype, RV external x 2.5 and dorsal aspect x 4.0. I ARI G2762/1, paratype, posterior flank of LV x 3.0. J ARI G2762/5, paratype, posterior flank of RV x 3.0. Nemodon (N.) filistriata (Stoliczka). K, L ARI G2877/1, RV external and dorsal aspects both $\times 2$. M, N ARI G2763/2, LV external x 2 and dorsal aspect $\times 3.5$.

subtrigonal, posterior area concave, strongly defined by umbonal carination; umbones inflated, prosocline, slightly elevated; beaks incurved, opisthogyrate, at anterior two fifths but median to cardinal area; hinge and ventral margins subparallel, extremities of former obtusely angulate; anterior margin rounded; posterior margin obliquely truncate, forming blunt angulation with ventral margin; cardinal area narrowly lanceolate, extending along entire hinge margin, broader behind beak; ligament prosodetic, cross-ridged, extending from beak to just short of anterior extremity of area; hinge plate narrow; hinge largely obscured, where visible, arcoid, of numerous, fine, short, evenly graded, close teeth, convergent on point below beak; sculpture faint, of low, commarginal growth ridges, crossed by a few obscure, spaced, radial threads, more evident on posterior area; from LV mould, adductor scars lightly impressed, anterior scar bordered on inner 
side by a weak, short, myophoric ridge; ventral margin without crenulae, byssal gape or sinus.

Dimensions of noetiid, genus and species undetermined.

\begin{tabular}{lcccc}
\hline Specimens & Length & $\begin{array}{c}\text { Length } \\
\text { hinge } \\
\text { margin }\end{array}$ & Height & Inflation \\
& \multicolumn{4}{c}{. } \\
\hline ARI G2882/1, RV & $9.40^{*}$ & 5.98 & 6.49 & 2.6 \\
ARI G2882/2, RV & 8.29 & 5.40 & 5.63 & 2.2 \\
ARI G2882/3, LV & $5.46^{*}$ & 2.96 & 3.38 & 1.6 \\
ARI G2882/4, RV & $8.67^{*}$ & 4.67 & 5.81 & 2.3 \\
ARI G2882/5, RV & 7.11 & - & 4.88 & 2.3 \\
\hline
\end{tabular}

* estimates - slight posterior damage

\section{Remarks}

The noetiid affinity of these small, possibly immature shells is established by the combination of their confined, essentially prosodetic and crossstriated ligament, the presence of a myophoric ridge adjoining the anterior adductor scars and the prosogyrate umbones and opisthogyrate beaks. The inner ventral margin, as shown on one LV mould, is essentially non-crenulate and the external surface is almost smooth apart from weak growth lines and a few obscure, mainly posterior radials. This combination of characters does not accommodate readily any of the noetiid subfamilies and genera in the taxonomic arrangement of Newell (in Moore 1969: N261N264, figs C9, C10), suggesting the presence of a new species and probable new genus. The few specimens presently to hand are inadequate to establish a taxonomic identity for this species, which must await the collection of further material.

\section{Occurrence}

Uttattur Group. Odiyam Locality 3. Karai Formation (Kunnam Member). Cenomanian. Uncommon. This is the first record for the Noetiidae from the Cretaceous of India.

\section{Family Parallelodontidae Dall, 1898}

\section{Subfamily Grammatodontinae Branson, 1942}

\section{Genus Grammatodon Meek and Hayden, 1861}

\section{Type species}

Arca (Cucullaea) inornata Meek and Hayden, 1858 , by original designation. Jurassic, $\mathrm{N}$ America.

\section{Subgenus Nanonavis Stewart, 1930}

\section{Type species}

Arca carinata J. Sowerby, 1813, by original designation. Albian, England.

\section{Grammatodon (Nanonavis) subcrenulatus sp. nov. \\ Figure $3 \mathrm{E}-\mathrm{J}$}

\section{Material examined}

Holotype

ARI G2762/2, LV, from brown calcareous siltstone with abundant turritellid gastropods beside track ca $0.5 \mathrm{~km}$ west of Odiyam village, Perambalur Taluk, Tiruchirapalli district, Tamil Nadu (Locality 2).

\section{Paratypes}

ARI G2762/1, 3-14, four LVs and nine RVs from type locality. Total of 14 single valves.

\section{Other material}

ARI G2687, 10 LVs, 24 RVs (includes three internal moulds), Locality 1. G2762, $26 \mathrm{LVs}, 71 \mathrm{RVs}$ (includes five internal moulds), Locality 2. G2878, one LV, three RVs, Locality 3 . Total of 135 single valves (plus type material).

\section{Diagnosis}

Small, valves discrepant, RV more inflated and with more numerous, narrower costellae than LV; ventral margin (both valves) weakly crenulate.

\section{Description}

Shell small for subgenus, length up to $23 \mathrm{~mm}$, elongate, trapezoidal, trigonal and alate at posterodorsal extremity; valves moderately discrepant, RV more inflated; umbones elevated, broad, inflated, prosogyrate; beaks at anterior third, incurved and transgressing ligamental area; area lanceolate with chevron insertion grooves mainly behind beaks, posterior series more numerous than anterior. Dorsal margin straight, ca nine tenths of valve length, slightly divergent from ventral margin and forming slightly acute angle with roundly descending anterior margin; posterior margin truncated, oblique, meeting dorsal margin at slightly obtuse angle and ventral margin at angulation formed by strong umbonal carina; ventral margin sinuate, consistent with small byssal gape; carina prominent on each valve, more so on LV where it bears rib; posterior area broad, excavate, more so on LV; ventral margin weakly internally crenulate on each valve.

Sculpture discrepant, of fine, low radial costellae with subordinate, close, commarginal threads, latter more prominent anteriorly and forming low ridges or scales at points of intersection with radials; $\mathrm{LV}$ costellae wider and usually fewer than those of RV, comprising 20-23 spaced primaries, between which are second and third order costellae, arising usually by intercalation, occasionally by bifurcation and with much individual variation; posterior area (LV) with four to six primary costellae, of which median is 
Table 10 Total rib counts relative to shell height on specimens of (a) G. (N.) subcrenulatus (Karai Formation, Cenomanian) and (b) G. (N.) carinatus (Blackdown Greensand, Upper Albian). Sample sizes: Odiyam five LVs, six RVs; Blackdown (NHM L16999) ten LVs, six RVs. The rib on the carina of the LV has been included in the disc count.

(a)

$\begin{array}{lc} & \text { disc } \\ \text { LV } & 39-49(\text { mean } 44.0) \\ \text { RV } & 47-52(\text { mean } 49.0)\end{array}$

(b)

LV

RV disc

$33-45$ (mean 40.2 ) ca $41-53$ (mean 46.0$)$
Odiyam

posterior area

16-23 (mean 19.0)

$16-24$ (mean 19.7)

Blackdown

posterior area

$11-18$ (mean 15.0$)$

ca $15-19($ mean 17.0$)$ shell height

9.4-13.3 (mean 11.1)

7.6-9.8 (mean 8.8)

shell height

11.0-24.7 (mean 17.6)

9.1-19.0 (mean 14.5) usually strongest and with second/third order costellae intercalated; RV disc with 22-30 primary costellae and variable combinations of secondary/ tertiary costellae; posterior area (RV) sculptured like that of LV; on both valves, number of costellae increases with growth; intercostal spaces generally wider on posterior half (particularly on LV), reflecting lower rate of rib generation compared with anterior portion. Adductor scars (from mould) lightly impressed, posterior larger; hinge with short, oblique anterior pseudolaterals and longer, subparallel (to hinge margin) posterior pseudolaterals; median teeth numerous, fine, short, convergent to point below beaks; all teeth finely serrate.

Dimensions of Grammatodon (Nanonavis) subcrenulatus sp. nov. All specimens being embedded in hard matrix, most inflation measurements are approximations.

\begin{tabular}{|c|c|c|c|c|}
\hline Specimens & Length & $\begin{array}{l}\text { Length } \\
\text { hinge } \\
\text { margin }\end{array}$ & Height & Inflation \\
\hline $\begin{array}{l}\text { ARI G2762/2, } \\
\text { LV, holotype }\end{array}$ & $22.24^{*}$ & 18.26 & 13.58 & 7.48 \\
\hline $\begin{array}{l}\text { ARI G2762/1, } \\
\text { LV, paratype }\end{array}$ & $18.92^{*}$ & 15.58 & 12.74 & 5.63 \\
\hline $\begin{array}{l}\text { ARI G2762/3, } \\
\text { LV, paratype }\end{array}$ & 15.90 & 15.64 & 12.23 & 5.58 \\
\hline $\begin{array}{l}\text { ARI G2762/4, } \\
\text { LV, paratype } \\
\text { ARI G2762/5, }\end{array}$ & 17.19 & 16.91 & 12 (est.) & 7.23 \\
\hline $\begin{array}{l}\text { RV, paratype } \\
\text { ARI G2762/6, }\end{array}$ & 15.59 & 13.61 & 10.56 & 6.10 \\
\hline $\begin{array}{l}\text { RV, paratype } \\
\text { ARI G2762/7, }\end{array}$ & 12.54 & 11.42 & 8.99 & 4.18 \\
\hline $\begin{array}{l}\text { RV, paratype } \\
\text { ARI G2687/1, }\end{array}$ & 15.34 & 13.74 & 9.62 & 5.60 \\
\hline RV & 18.24 & 16.84 & 11.72 & 7.10 \\
\hline
\end{tabular}

* estimates - slight posterior damage

\section{Remarks}

The present species is very close to Grammatodon (Nanonavis) carinatus (J. Sowerby), type species of Nanonavis, from the Albian-Cenomanian of Western Europe (Marlière 1939: 13). The geographical range of that species has been extended into Central Europe, Russia, N Africa including Egypt (i.e., Tethyan) by Mongin (1979, tab. 9-1) with an overall stratigraphic range of Aptian-Turonian. From Sowerby's species, G. (N.) subcrenulatus differs mainly in the more numerous second and third order costellae, which arise chiefly by intercalation, occasionally by bifurcation. This subordinate sculpture, as well as the spacing of the radials on both anterior and posterior areas, show much individual variation. Because primary and other radials form a size-continuum in our material, their assessment is unavoidably subjective. We have therefore made total rib counts (all sizes) from Odiyam specimens and compare these with Blackdown examples of $G$. (N.) carinatus.

Though of smaller size, the Odiyam specimens tend to have more ribs (mostly second and third order) than the larger Blackdown examples. In the Karai Formation, the present species is associated with numerous large arcoids (e.g., Trigonarca spp. at Locality 3) and we conclude that its observed size range there approximates to actual life-size and is not a consequence of post-mortem transportation and sorting. However, no paired valves of $G$. (N.) subcrenulatus (nor of Trigonarca) are present in the study material.

The faint but distinct presence of internal marginal crenulation also distinguishes the present species from Grammatadon (Nanonavis) carinatus. This character appears to lack constancy within the subgenus, for example both valves are crenulate in $G$. (N.) natalensis (Baily) from the Senonian of Pondoland and Madagascar; only the LV is crenulate in G. (N.) subdiscors Darragh and Kendrick from the Maastrichtian of Western Australia (Darragh and Kendrick 1991). Also close to the present species is $G$. (N.) yokoyamai Yabe and Nagao from the Upper Neocomian-Albian of Japan (Hayami 1965a: 238-241, pl. 27, figs 8-13), which differs from $G$. (N.) subcrenulatus in its fewer costellae, (apparently) smooth ventral margins and greater size. G. (N.) japeticum (Forbes), Ariyalur Group, is larger, shorter relative to height, much more inflated with a wider ligamental area 
and is less carinate than the Odiyam species.

Grammatodon (Nanonavis) was associated by Kauffmann (1973: 367, 371) with his North Temperate Realm, but clearly the subgenus is well represented in the Late Cretaceous of the Indian Ocean region and elsewhere, attaining nearcosmopolitan status (Darragh and Kendrick 1991: 19, 20). Three specimens (G2687, Locality 1) out of 149 in the study material bear naticiform boreholes, one near the ventral margin of the LV, the others on the umbonal areas of RVs. One other bears a borehole of different form.

\section{Etymology}

From the Latin crenatus, notched (masculine) and prefix $s u b$-, less than, with reference to the reduced marginal crenulation compared with that of $G$. (N.) carinatus.

\section{Occurrence}

Uttattur Group. Odiyam Localities 1, 2 (type) and 3. Karai Formation (Odiyam and Kunnam Members). Cenomanian.

\section{Genus Nemodon Conrad, 1869}

\section{Type species}

Arca (Macrodon) eufalensis Gabb, 1860, by original designation. Maastrichtian, eastern $\mathrm{N}$ America.

\section{Subgenus Nemodon s. str}

\section{Nemodon (Nemodon) filistriata (Stoliczka, 1871) Figure $3 \mathrm{~K}-\mathrm{N}$}

1871 Arca filistriata Stoliczka: 357, pl. 17, fig. 37; pl. 50, fig. 6.

1987 Arca Filistriata [sic] Stoliczka; Tapaswi: 506. List only.

\section{Material examined}

\section{Lectotype}

Here designated. GSI Stoliczka Collection 1193, LV, from north of Odiyam, Uttattur Group.

\section{Other material}

ARI G2688, eight LVs, five RVs, Locality 1; G2763, nine LVs, eight RVs, ten internal moulds, Locality 2; G2877, four LVs, six RVs, seven internal moulds, Locality 3. Total of 57 ARI specimens, all single valves. Additionally, G2763/2 shared with specimen of Profragum praecurrens (Stoliczka).

\section{Diagnosis}

Medium sized Nemodon s. str. (length to $37 \mathrm{~mm}$ ) with length to height ratio of ca $2: 1$; valves discrepant, RV more strongly carinate and with more numerous radial costellae; umbones and disc medially sulcate, with corresponding internal rib, stronger on LV.

\section{Description}

Specimens mostly small, immature, occasionally approaching mature size and thick-shelled; elongate, subrhomboidal, moderately inflated, maximum inflation slightly posterior of beaks; valves discrepant; umbones broad, low, with median sulcus, stronger on LV; beaks incurved, well separated, prosogyrate, at anterior third; ligamental area of moderate size, elliptical, widest either anterior or posterior to beaks; posterior insertion lines exceeding by one those of anterior series; posterior area well defined, excavate, bounded by rounded carinae, stronger on RV; hinge margin straight, ca 0.75 times total length, slightly divergent from ventral margin; anterior margin obliquely rounded; posterior margin obliquely truncate; ventral commissure flexuous, with median byssal gape.

Sculpture discrepant, variable, of numerous fine, close radials of unequal width and spacing, which increase by both bifurcation and intercalation, those of LV tending broader and flatter than RV; disc of RV (i.e., anterior of carina) with 34-57 costellae (six valves), that of $\mathrm{LV}$ with 38-44 costellae (seven valves); intercalary threads occasionally present; posterior areas with 10-20 costellae of variable strengths, finer dorsally and usually including more prominent median rib; rib counts vary according to rates of new rib generation and shell size; radials crossed by subordinate commarginal striae, which intensify anteriorly to become finely gemmate or occasionally (LV) tegulate. Hinge plate narrow, with two or three short, slightly oblique anterior and three elongate, sub-parallel posterior pseudolaterals; median teeth short, oblique, convergent on point slightly below beak; adductor scars lightly impressed, large, anterior roundly subquadrate, located below hinge at antero-dorsal

Dimensions of Nemodon (N.) filistriata (Stoliczka).

\begin{tabular}{lcccc}
\hline Specimens & Length & $\begin{array}{c}\text { Length } \\
\text { hinge } \\
\text { margin }\end{array}$ & Height & Inflation \\
\hline $\begin{array}{c}\text { GSI 1193, } \\
\text { lectotype, LV }\end{array}$ & $37.3^{*}$ & $?$ & 22.84 & ca 9.55 \\
$\begin{array}{c}\text { ARI G2688/1, } \\
\text { RV }\end{array}$ & 10.32 & 8.88 & 5.52 & 2.47 \\
$\begin{array}{c}\text { ARI G2763/1, } \\
\text { LV }\end{array}$ & 10.20 & 8.48 & 6.32 & $?$ \\
$\begin{array}{c}\text { ARI G2877/1, } \\
\text { RV }\end{array}$ & 27 (est.) & 21.32 & 17 (est.) & 7.2 (est.) \\
\hline
\end{tabular}

* specimen lacks several mm anteriorly and ca $10 \mathrm{~mm}$ posteriorly; estimated original length ca $50 \mathrm{~mm}$. 
extremity; posterior large, obscure, located high on posterior slope; margins of LV crenulate, crenulae extending to pallial line, obsolete on median area; RV crenulation much weaker to obscure; interior of juvenile LV with strong, broad median rib corresponding to external byssal sulcus; rib and sulcus weaker on RV; within pallial line, body cavity shows obscure radial striae.

\section{Remarks}

Arca filistriata was described (Stoliczka 1871) from a single incomplete LV from "North of Odium [=Odiyam], in a brownish limestone; very rare. Ootatoor Group". The second of his two figures (on pl. 50) is a much more accurate depiction of the specimen. The surface of Stoliczka's specimen is worn, with partial loss of sculpture but retains fine, close, radial costellae and narrow interspaces, new costellae arising by intercalation. The posterior area is sculptured similarly, with the addition of a strong median rib formed by aggregation of about six costellae. A weakly angulate shoulder separates the area from the disc, which bears a prominent median sulcus. Stepped growth-pause lines indicate a mature to gerontic specimen. The ligamental area measures $27 \times 4 \mathrm{~mm}$ and was probably longer anterior of beak; the latter, worn and damaged, extends a little over the area. Internal characters and hinge are obscured by a hard, khaki-brown, coarse grained, calcareous sandstone.

The study material from Odiyam agrees substantiaily with the external characters of the lectotype and provides the first evidence of RV and internal characters, hitherto undescribed.

The holotype and only known specimen of Nemodon (N.) garudamangalensis Chiplonkar and Tapaswi (ARI Gr. 179/70), an LV from "Brownish earthy rock from Trichinopoly Group at about 1.5 km SE of Garudamangalam" (Chiplonkar and Tapaswi 1976a: 216, pl. 1, fig. 6), probably from the Turonian Kulakkalnattam Formation, lacks the anterior, most of the ventral and part of the posterior portions and externally is rather worn. However, sufficient of the hinge remains to confirm the generic identity. Originally, it was probably a little smaller than Stoliczka's specimen of $N$. (N.) filistriata; it is also thinner and lacks the stepped, gerontic growth pauses of the older species. Other differences between the above mentioned types concern mainly the ligamental areas and sculpture. On the younger specimen, the ligamental area width is less than half $(1.9 \mathrm{~mm}$ against $4.0 \mathrm{~mm})$ that of the older and was probably shorter. On both, the areas seem to extend mainly anterior of the beak but, as neither is complete, some uncertainty remains. On $N$. (N.) garudamangalensis, rib generation occurs mainly, if not entirely, by bifurcation. On Stoliczka's type, intercalary growth predominates, though abrasion has removed some fine detail on both. The prominent median rib on the posterior area is much stronger on the Stoliczka type. From their different stratigraphic horizons and the small but distinct morphological differences between them, albeit from very limited material of the younger, we view these as separate species, probably representing parts of a single evolutionary lineage ranging from the Cenomanian to Turonian. The collection of more material from the Kulakkalnattam Formation, including the RV of $N$. garudamangalensis, will facilitate a clearer comparison of the two species.

The present species, Nemodon (N.) filistriata, is a typical Nemodon, related to $N$. (N.) eufalensis (Gabb) from the Maastrichtian of $N$ America (Wade 1926: 42, 43, pl. 8, figs 17, 18). The species are similar in proportions and sculpture, differing in the position of the ligamental area relative to the beaks and in the presence of internal crenulation on the LV (of the present species). Arca natalensis Baily from the Senonian of Pondoland was assigned to the genus Nemodon by Woods (1906) but seems better located in Grammatodon (Nanonavis). Nemodon s. str. is among the genera cited by Kauffmann (1973: 368 ) as "restricted to, or most common in, the North American Province ...". This is the second record of the genus from the Uttattur Group and the third from the Cretaceous of south India.

\section{Occurrence}

Uttattur Group. North of Odiyam in a brownish limestone (type). Karai Formation. Cenomanian. Odiyam localities 1, 2 and 3. Karai Formation (Odiyam and Kunnam Members). Cenomanian.

\section{Family Cucullaeidae Stewart, 1930}

\section{Genus Trigonarca Conrad, 1862, emended Stoliczka, 1871}

\section{Type species}

Cucullaea macoensis Conrad, 1860, by original designation. Late Cretaceous, eastern N America.

\section{Remarks}

The hinge, shell form and affinities of Trigonarca are distinctly cucullaeoid according to Thomas (1978a, b), a view with which we concur. This is contrary to the arrangement of Newell (in Moore 1969: N269), which would locate the genus within the Glycymeridae.

\section{Subgenus Costelliarca Chiplonkar and Tapaswi, 1973}

\section{Type species}

Arca trichinopolitensis Forbes, 1846, by original designation. 


\section{Remarks}

Chiplonkar and Tapaswi (1973) proposed a subdivision of the genus Trigonarca Conrad, limiting the subgenus $s$. str. to those species combining the characters "Subtrigonal; opisthogyrate; without radial ornament". Their new subgenus, Costelliarca, was erected for species that are "Subtrigonal to subtrapezoidal, orthogyrate to opisthogyrate; ornamented with fine radial costellae; posteroventral carina not sharp".

Scrutiny of a number of radially costellate species of Trigonarca shows this sculptural feature to be associated with a wide range of shell morphologies. The usual shell form exhibited by this group is subquadrate to subtrapeziform, posteriorly more or less subtrigonal and with much intra- and interspecific variation; beaks may be slightly prosogyrate to slightly opisthogyrate. Some examples of this form group are the species brahminica Forbes, capensis Greisbach, duplex Chiplonkar and Tapaswi, galdrina d'Orbigny, gamana Forbes, ligerensis d'Orbigny, pusilla Nayak and Badve, teleguensis Stoliczka, trichinopolitensis Forbes and punctulata new species (this paper). Other radially costellate species of Trigonarca have elongate, submytiliform shells, for example, elongata Rennie and mongraensis Chiplonkar and Badve. A less common, costellate, but distinctive morphology, represented by the species abrupta Forbes, has an obliquely triangulate, subtrigonal shell, which is markedly short and reduced posteriorly.

The above species present a range of combinations of other characters, such as beak orientation (mostly orthogyrate to slightly prosogyrate, less often opisthogyrate), size, shape and disposition about the beaks of the ligamental area, degree of spirality and inflation of the umbones and the profile of the posterior shoulder (Stoliczka 1871, Woods 1906, Newton 1909, Rennie 1930, Chiplonkar and Badve 1973, Chiplonkar and Tapaswi 1976a and this paper, below). These diverse character combinations derive from an integrated and co-dependent suite of unspecialised arcoid growth parameters, that must generate a functionally adaptive shell form compatible with unstable inner shelf habitats (Thomas 1976, 1978a, b). Within Trigonarca, these combinations vary extensively across a broad continuum of morphologies and we conclude that random character groupings, selected arbitrarily from the mélange are of limited taxonomic value. In retaining the subgenus Costelliarca, we propose its redefinition to receive all species of Trigonarca, regardless of shell form, which possess radial sculpture. Species without radials would remain in Trigonarca s. str.

Three species of Costelliarca are known from the Karai Formation at Odiyam. Each of these in the juvenile state has a distinct sulcus on either one or both beaks, suggesting byssal attachment in early life. With growth, shells become non-sulcate, posteriorly sub-trigonal and produce a length to height ratio usually less than 1.35; falcate to chevron-shaped teeth also develop. This particular character combination, together with a moderately robust shell, indicates a free-living, active, burrowing mode of life in an unstable, shallow inshore shelf environment (Thomas 1976, 1978a, b). A partial exception to this is the variable $T$. (C.) trichinopolitensis, of which the length to height ratios may extend both above and below 1.35 (see below).

\section{Trigonarca (Costelliarca) trichinopolitensis (Forbes, 1846) \\ Figure 4 A-J}

1846 Arca trinchinopolitensis Forbes: 150, pl. 15, fig. 16.

1871 Trigonoarca Trichinopolitensis Forbes; Stoliczka: 353, pl. 18, figs 12, 14; pl. 19, figs 2, 3; pl. 20, figs $2,8-10$.

1973 Trigonarca (Costelliarca) trichinopolitensis (Forbes); Chiplonkar and Tapaswi: 653. As type species of Costelliarca subgen. nov.

1976a Trigonarca (Costelliarca) trichinopolitensis (Forbes); Chiplonkar and Tapaswi, tab.1: 220.

1977a Trigonarca (Costelliarca) trichinopolitensis (Forbes); Chiplonkar and Tapaswi: 16, 17.

1979 Trigonarca (Costelliarca) trichinopolitensis (Forbes); Chiplonkar and Tapaswi: 138, 151.

1987 Trigonarca (Costelliarca) trichinopolitenois [sic] (Forbes); Tapaswi: 506. List only.

\section{Lectotype}

Here designated. NHM Forbes Collection Geological Society, no. 10620, conjoined pair from "Trinchinopoly and Verdachellum".

\section{Paralectotypes}

NHM Forbes Collection, Geological Society nos 10621, one LV; L56544-7, three LVs, one RV, ex C.T. Kaye and C.E. Cunliffe, all with same locality data and "Trichinopoly Group". There is doubt concerning the reliability of Forbes' localities for this species (see Remarks, below).

\section{Other material}

GSI Stoliczka Collection 1208, 1210, 1212, 1213, $1223,1224,1225$; six conjoined pairs, one RV from "Anapaudy, Garudamungalum, Serdamungalum and Alundanapuram" (Stoliczka 1871). The probable stratigraphic sources of Stoliczka's material are discussed further below. ARI G2778; three LVs, one RV, Odiyam Locality 2. G2879; four 


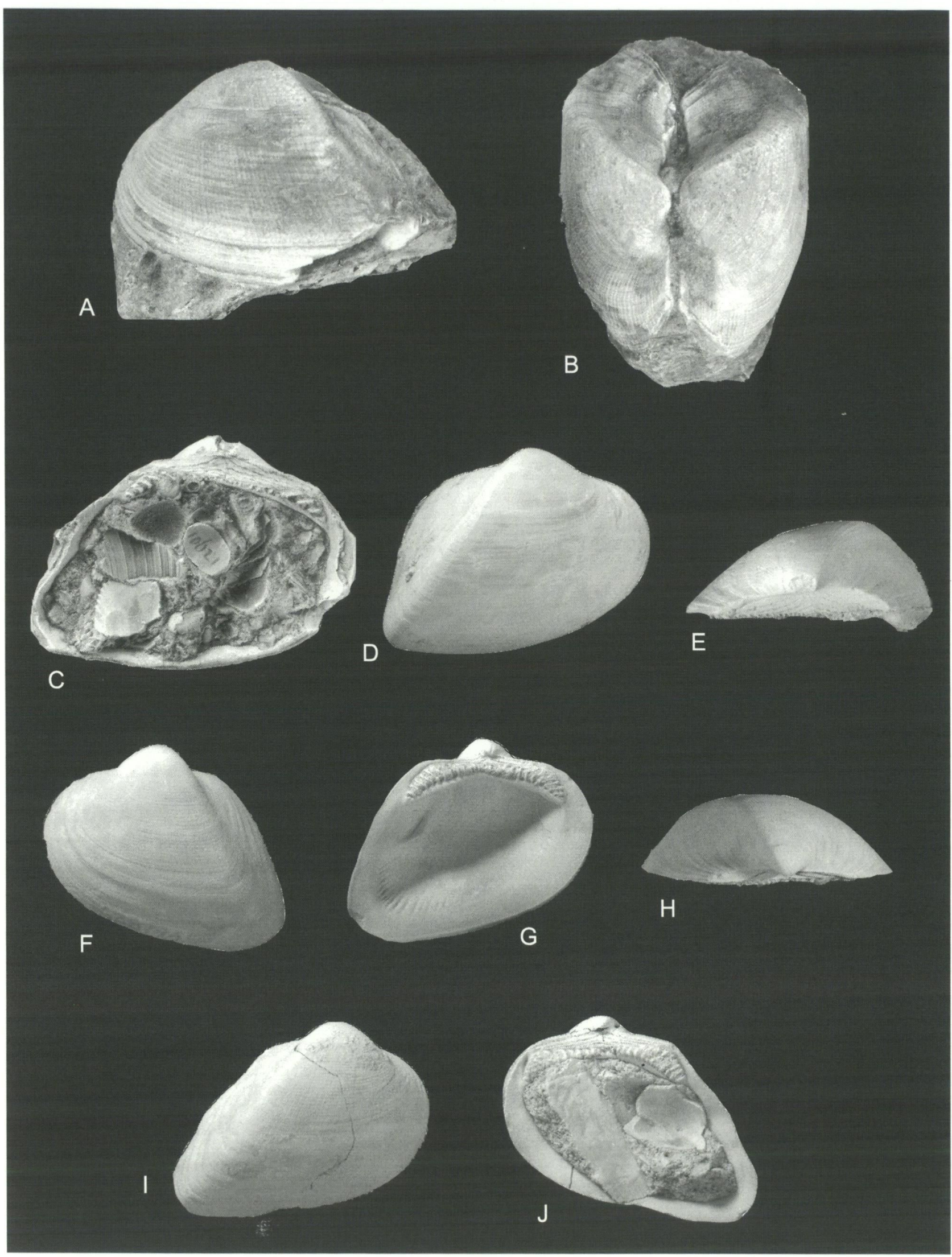

Figure 4 Trigonarca (Costelliarca) trichinopolitensis (Forbes). A, B NHM (Geological Society Collection) 10620, lectotype, conjoined pair, LV and dorsal aspect x 1. C NHM (Geological Society Collection) 10621, paralectotype, LV internal x 1. D, E ARI G2879/5, RV external and dorsal aspects x 1. F-H ARI G2871/1, LV external, internal and dorsal aspects x 1. I, J ARI G2879/6, RV external and internal x 1. 
LVs, four RVs, Odiyam Locality 3. Totals: NHM six, GSI seven, ARI 12 specimens: combined total of 25 specimens.

\section{Diagnosis}

Medium-sized, subtrapezoidal, variable Costelliarca, length to $70 \mathrm{~mm}$, valves discrepant, $\mathrm{LV}$ usually more inflated and overlapping RV; sculpture of fine radials, closer on RV, mostly on umbonal areas of both valves, often more prominent on postero-ventral shoulder; hinge plate broad, set subequally about beaks or extended posteriorly; umbones prosogyrate; beaks orthogyrate to slightly prosogyrate, submedian to ligamental area.

\section{Description}

Medium size for genus, thick, robust, subtrapezoidal, subtrigonal; valves discrepant, LV usually more inflated and overlapping slightly ventral margin of RV; short and rounded anteriorly, obliquely truncate posteriorly, areas offset by roundly subangulate postero-ventral shoulder; umbones broad, inflated, elevated, prosogyrate; beaks incurved, blunt, weakly sulcate on LV, orthogyrate to slightly prosogyrate and transgressing apex of ligamental area; area broad to narrow, equal in length to about half that of shell, either more or less equally disposed about beaks or shortened posteriorly; distribution of insertion lines variable; hinge cucullaeoid, hinge plate and dental arch strong, often slightly longer posterior to beaks, posterior extremity descending; teeth in three series, anterior ten large, obliquely falcate, except for distal two or three which with growth become subparallel to hinge margin; median series about six, short, vertical, crowded; posterior twelve, large, mostly falcate, distal three or four straight, oblique to margin and more or less parallel.

Adductor scars of medium size, lightly impressed, anterior obliquely subtrapezoidal, higher than long, near end of hinge plate; posterior scar slightly larger, of irregular outline, longer than high, on a well developed myophoral flange; pallial line entire, marginal to body cavity; row of short, radial attachment grooves, stronger posteriorly, connects adductor scars along inner side of pallial line; ventral margin smooth, bevelled on LV.

Sculpture of very fine to faint radial costellae of variable width, spacing and persistence (closer on $R V$ ), mainly on umbones, anterior area and particularly on and around shoulder; radials become obsolete with growth; very fine, close, commarginal striae cancellate radials, persisting as commarginal growth ridges as radials disappear; stronger median rib (occasionally two) present on posterior area of RV only.

\section{Remarks}

Forbes' (1846) introduction of the name Arca trinchinopolitensis was intentional, as is shown clearly by his consistent utilisation in the same work of the identical specific name in three other combinations (with the genera Cerithium, Murex and Voluta), accompanied therein by citations of the locality name "Trinchinopoly", the latter being cited in many other contexts in the same work as a locality name. This south Indian city became widely known in its anglicised form "Trichinopoly" and latterly as Tiruchirapalli.

Dimensions of Trigonarca (Costelliarca) trichinopolitensis (Forbes). Lengths measured parallel to hinge margin, heights normal to it.

\begin{tabular}{lcccc}
\hline Specimens & Length & Height & L/H & Inflation \\
\hline NHM Geol. Soc. 10620, pair, lectotype & 60.82 & 44.92 & 1.35 & 23.1 (LV, est.) \\
& & & & 20.4 (RV, est.) \\
NHM Geol. Soc. 10621, LV, paralectotype & 54.76 & 42.14 & 1.29 & 17.99 \\
NHM L56544, LV, paralectotype & 60 (est.) & 40.86 & - & 20 (est.) \\
GSI 1208, pair & 22.92 & 16.94 & 1.35 & 11.61 \\
GSI 1210, pair & 38.06 & 32.50 & 1.17 & 23.30 \\
GSI 1212, pair & 70.68 & 47.70 & 1.48 & 42.26 \\
GSI 1213, pair & 53.72 & 44.24 & 1.21 & 35.24 \\
GSI 1223*, pair & 63.32 & 40.47 & 1.56 & 31.22 \\
GSI 1224, pair & 35.24 & 24.71 & 1.42 & 19.49 \\
GSI 1225**, RV & 51.62 & 37.84 & - & 17.42 \\
ARI G2879/1, LV & 43.02 & 37.82 & 1.14 & 13.60 \\
ARI G2879/2, LV & 54.15 & 40.29 & 1.34 & 21.86 \\
ARI G2879/3, LV & 38.60 & 35.42 & 1.09 & 13.66 \\
ARI G2879/4, RV & 51.81 & 41.32 & 1.25 & 19.96 \\
ARI G2879/5, RV & 43.77 & 35.23 & 1.24 & 15.20 \\
ARI G2879/6, RV & 45.34 & 39.04 & 1.16 & $\mathbf{1 7 . 1 2}$ \\
\hline
\end{tabular}

\footnotetext{
* a rather elongate specimen
}

** broken posteriorly 
Stoliczka's (1871) adoption of the name "trichinopolitensis" for Forbes' species was, in terms of the current International Code of Zoological Nomenclature, an unjustified emendation but as all subsequent citations of the name followed the Stoliczka formulation, with original author and date, this may now be accepted as a "justified emendation" in accordance with ICZN (1999: 42), Article 33.2.3.1.

The type material of Arca trichinopolitensis Forbes, at the Natural History Museum, London, comprises three lots:

(i) Geological Society no. 10620, (Figure 4 A, B) paired valves, gaping, slightly damaged (see Dimensions). Exteriors are worn and little can be made from comparison of valves; they are however not greatly dissimilar. Sculpture of fine, close radials, narrower and more spaced anteriorly; radials present on rounded (not carinate) posteroventral shoulder; posterior area slightly excavate. Label cites this specimen as that depicted in Forbes' pl. 15, fig. 16. The figure is an idealised representation of the specimen, omitting breakages and adherent sediment, a hard, grey, shelly calcarenite.

(ii) Geological Society no. 10621, (Figure 4 C) LV. Most of shell bears weak, fine, radial costellae, which fade by about last $11 \mathrm{~mm}$ of growth; ligamental area shortened posteriorly, extended anteriorly; tip of beak missing. Label cites this as specimen shown in Forbes' fig. 16b, which is not an accurate depiction. Ligamental area is more extended anteriorly than figure shows and hinge is more asymmetric, posterior side being more descending. Specimen has four anterior and five posterior teeth, contrary to Forbes' account of four at each end; posterior series descends a little more than does anterior.

(iii) Kaye and Cunliffe Collection nos L56544, LV with fine radial ribbing except on ventral $10 \mathrm{~mm}$; shoulder prominent, rounded. L56545, RV juvenile, with orthogyrate beak and narrow, spaced ribs; beak and ligamental area missing. L56547, LV juvenile with slightly prosogyrate beak; with fine radial ribs, broad and close medially, narrower and spaced at each end; ligamental area shorter posteriorly.

We designate the above Geological Society specimen no. 10620 as lectotype of Arca trichinopolitensis Forbes, all the other Forbes specimens cited above becoming paralectotypes of that species. Forbes' localities were "Trinchinopoly and Verdachellum" but there is nothing on the labels to indicate the actual source of any specimen. Forbes (1846) noted that, "The specimens from the former place are somewhat wider". The occurrence of the species at Verdachellum (=Vriddhachalam) requires confirmation (K. Ayyasami, personal communication, 1996).
New (ARI) material from the Uttattur Group, Karai Formation, at Odiyam has been compared with Forbes' type series and also with the figured specimens of this species in the GSI Stoliczka Collection, Kolkata (see Material above) and we conclude that, with one exception noted below, all are conspecific. Of Stoliczka's four localities, three (Anaipadi, Garudamangalam, and Alundalippur) are associated with the Trichinopoly Group, i.e., Kulakkalnattam Formation (Turonian), whereas the other, Saradamangalam, may represent the Sillakkudi Formation (Santonian-Campanian), Ariyalur Group. GSI specimen no. 1217, a single RV, appears to be a misplaced Grammatodon with a hinge typical of that genus and is not the specimen figured in Stoliczka (1871, pl. 20, fig. 2), as the label asserts.

On most of the Stoliczka specimens (conjoined pairs), the LV overlaps the RV slightly along the ventral margin and appears also to be slightly more inflated; beak orientation is mostly orthogyrate, less often (e.g., no. 1213) slightly prosogyrate. On five of the paired specimens, sculpture is discrepant with radials closer together on the $R V$; a worn $R V$ on the sixth pair (no. 1212) precludes comparison. Most specimens show a more prominent median rib on the RV posterior area; a weak sulcus on the LV beak of some specimens indicates byssal attachment in the juvenile stage. The material to hand confirms the observation of Stoliczka (1871: 353) that, "This is, as regards form, a very variable shell, some specimens being almost quadrangular and others nearly trapezoidal but they are posteriorly always strongly ridged, considerably more produced than anteriorly, and at the margin obliquely truncated". Other variable characters include the length to width ratio of the ligamental area, the position of the beaks relative thereto, beak orientation (orthogyrate to slightly prosogyrate), the disposition of the dental arch about the beak and the strength and persistence of the radial sculpture.

Rennie's (1929: 11,12, pl. 4, figs 8, 9) record of "Trigonoarca cf. trichinopolitensis (Forbes)" from the Senonian (Campanian?) of Angola appears to refer to another species (Chiplonkar and Tapaswi 1977: 16, 17 and references). The figures indicate a shell ca $54 \mathrm{~mm}$ long with cancellate sculpture extending to the mid-ventral margin, a feature unknown to us on any south Indian Trigonarca. The present species differs from the associated $T$. (C.) gamana (Forbes) by its more elevated umbones, wider hinge plate, stronger teeth, more divergent margins and greater size; from T. (C.) punctulata sp. nov., differs in the absence of punctate microsculpture.

\section{Occurrence}

Uttattur Group. $2.5 \mathrm{~km} \mathrm{NE}$ of Odiyam (Chiplonkar and Tapaswi 1977a). Karai Formation 


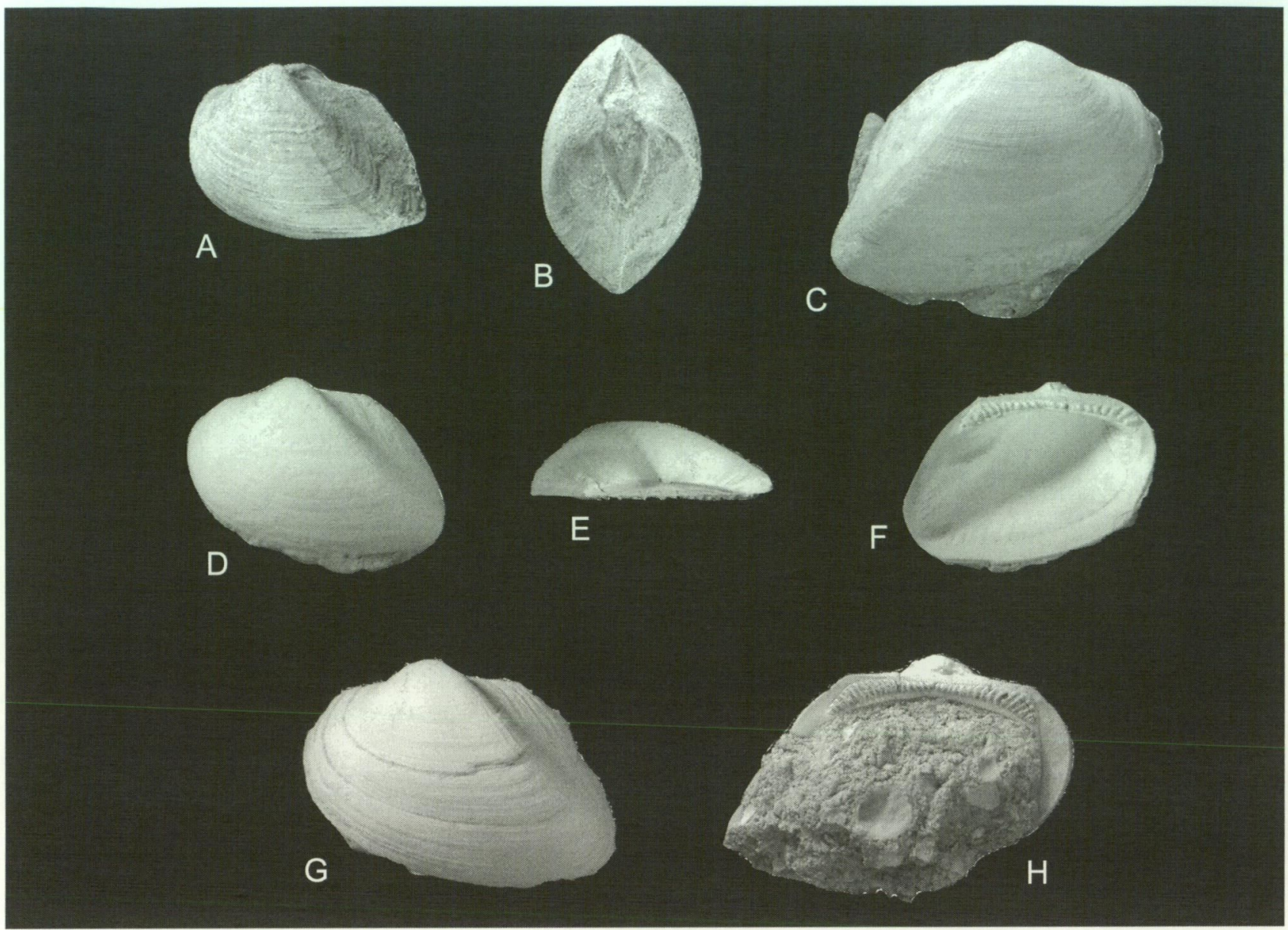

Figure 5 Trigonarca (Costelliarca) gamana (Forbes). A, B NHM (Geological Society Collection) 10616, lectotype, conjoined pair, LV external and dorsal aspects x 1. C ARI G2880/1, RV external (note shoulder radials) x 1. D-F ARI G2764/1, LV external, dorsal, internal x 1. G ARI G2764/6, LV external x 1. H ARI G2880/5, LV internal $\times 1$.

(Kunnam Member ?). Cenomanian. Odiyam Localities 2 and 3. Karai Formation (Odiyam and Kunnam Members). Cenomanian.

Trichinopoly Group. Anaipadi, Garudamangalum and $1.5 \mathrm{~km}$ NE of Alundalippur. Probably all Kulakkalnattam Formation. Turonian. Saradamangalam. Probably Anaipadi Formation. Coniacian. All from Stoliczka (1871).

Ariyalur Group. "Trinchinopoly and Verdachellum" (type) (Forbes 1846). Formations and ages not specified but latter (=Vriddhachalan) possibly from Aladi Formation (Maastrichtian) (Sundaram et al. 2001: 756, fig. 2).

\section{Trigonarca (Costelliarca) gamana (Forbes, 1846)} Figure $5 \mathrm{~A}-\mathrm{H}$

1846 Arca Gamana Forbes: 148, 149, pl. 16, fig. 3.

1847 Arca similis d'Orbigny, pl. 4, figs 33, 34. ex Stoliczka, 1871: 354, in synonymy.

1871 Trigonoarca Gamana (Forbes); Stoliczka: 354, pl. 20, figs 4, 5, pl. 50, fig. 7 .
1897 Trigonoarca gamana (Forbes); Kossmat: 65, 94.

1976a Trigonarca (Costelliarca) gamana (Forbes); Chiplonkar and Tapaswi: 220, tab. 1.

1979 Trigonarca (Costelliarca) gamana (Forbes); Chiplonkar and Tapaswi: 145, 151, 162.

1987 Trigonarca (Costelliarca) gamana (Forbes); Tapaswi: 506. List only.

\section{Material examined}

\section{Lectotype}

Here designated. NHM Forbes Collection. Geological Society no. 10616, conjoined pair from Pondicherry.

\section{Paralectotypes}

NHM Forbes Collection. L56557-8, conjoined pair and internal mould with remnant shell. Pondicherry.

\section{Other material}

GSI Stoliczka Collection nos 1219, 1220, one LV and one RV respectively. "Poodoor", Uttattur Group. 
ARI G2764, four LVs, two RVs, Odiyam Locality 2; G2880 four LVs, six RVs, Locality 3. Uttattur Group. Total of 21 specimens (NHM 3, GSI 2, ARI 16).

\section{Diagnosis}

Small to medium-sized (length to $49 \mathrm{~mm}$ ), obliquely subtrapezoidal Costelliarca with slightly prosogyrate to slightly opisthogyrate beaks, narrow hinge plate and fine hinge teeth; sculpture of weak radials, mainly on shoulder and umbones.

\section{Description}

Odiyam shells mostly small for species, robust, subtrapezoidal, subtrigonal, short and rounded anteriorly, obliquely truncate and produced posteriorly; plane of greatest inflation well behind beaks; LV probably slightly more inflated than RV; umbones broad, flattened, slightly elevated, prosogyrate; beaks incurved, blunt, weakly sulcate on LV, slightly opisthogyrate to slightly prosogyrate, barely transgressing ligamental area; posterior area slightly excavate, well defined by rounded shoulder; ligamental area of moderate width, equal to about half shell length, shortened posteriorly; insertion lines asymmetric, reduced posteriorly; hinge plate broadly arched, narrow, usually extended slightly posteriorly; teeth fine, in three series, anterior eight to 10 , oblique, some slightly falcate; median series about nine, short, vertical, crowded; posterior series 11-13, oblique, some falcate; all teeth finely serrate and convergent on point below beak; adductor scars large, lightly impressed, anterior higher than long, of variable shape, beneath and close to end of hinge plate; posterior adductor scar obliquely rectangular, below end of hinge plate on low myophoral flange; pallial line entire, bordered internally by row of short radial grooves and attachment pits; ventral margins smooth, bevelled on LV; sculpture of very fine to faint radial costellae, most evident around shoulder; elsewhere, radials usually present on umbo and anterior flank; radials become obsolete with growth; fine, close striae cross radials and merge into commarginal growth striae; posterior area of RV occasionally bears weak median rib.

\section{Remarks}

Forbes' material of $T$. (C.) gamana at the Natural History Museum comprises three lots:

(i) Geological Society 10616 is the conjoined pair figured by Forbes (1846) on pl. 16, figs 3a, 3b. The ligamental area is partly obscured by sediment as the figure shows; however the insertion lines drawn on the figure are actually concealed. LV is better preserved, RV abraded and incomplete; LV slightly overlaps RV along ventral margin.

(ii) L56557, conjoined pair lacking most of ventral margins; plane of greatest inflation well behind beaks; ligamental area and beaks obscured; surface much worn with obscure radials on posterior area.

(iii) L56558, internal mould with shell remnants on anterior third of $\mathrm{LV}$ and on small part of RV; well developed myophoral flange on each valve below posterior adductor scar.

We designate Geological Society specimen no. 10616 above to be lectotype of Arca gamana Forbes; specimens L56557 and L56558 thus become paralectotypes of that species. Forbes' locality, "Pondicherry", is presumably either from the Maastrichtian Valudavur or Mettuveli Formations.

The new study material from Odiyam has been compared with Forbes' specimens and also with GSI specimens (Stoliczka Collection) 1219 and 1220 and we consider them all to be conspecific. The latter, LV and RV respectively, appear to be those figured on Stoliczka's pl. 20, figs 4, 5. We have been unable to locate "the perfect specimen" from "Poodoor", Uttattur Group, depicted on Stoliczka's pl. 50, figs 7, 7a.

Stoliczka (1871: 354) noted that T. (C.) gamana and $T$. (C.) trichinopolitensis are "closely allied" and are indeed somewhat similar species, requiring care in separation, particularly where both occur together, as at Odiyam Locality 3 . There, T. (C.) gamana may be distinguished from the other by its lower umbones, narrower hinge plate, finer, more numerous teeth, less divergent dorsal/ventral margins and a tendency to smaller size. Differs from $T$. (C.) punctulata sp. nov. in the absence of punctate microsculpture. Kossmat (1897: 94) expressed reservations about Stoliczka's (1871) determination of Uttattur specimens as $T$. gamana,

Dimensions of Trigonarca (Costelliarca) gamana (Forbes).

\begin{tabular}{lcccc}
\hline Specimens & Length & Height & L/H & Inflation \\
\hline NHM Geol. Soc. 10616, pair, lectotype & 33.55 & 23.50 & 1.43 & 20.86 \\
NHM L56557, pair, pảralectotype & 39.70 & 27 (est.) & - & 25.04 \\
NHM L56558, int. mould, paralectotype & 33.7 & 21 (est.) & - & 18 (est.) \\
GSI 1219, LV & 49 & 31.5 & 1.23 & 15.52 \\
GSI 1220, RV & 46 & $-*$ & - & 17.26 \\
ARI G2764/1, LV & 33.44 & 25.35 & 1.31 & 10.02 \\
ARI G2764/2, LV & 40.72 & 31.16 & 1.31 & 14.60 \\
ARI G2880/1, RV & 43.86 & 34.51 & 1.28 & 16.81 \\
ARI G2880/2, RV & 37.42 & 30.20 & 1.23 & 11.56 \\
\hline
\end{tabular}

* umbo broken 

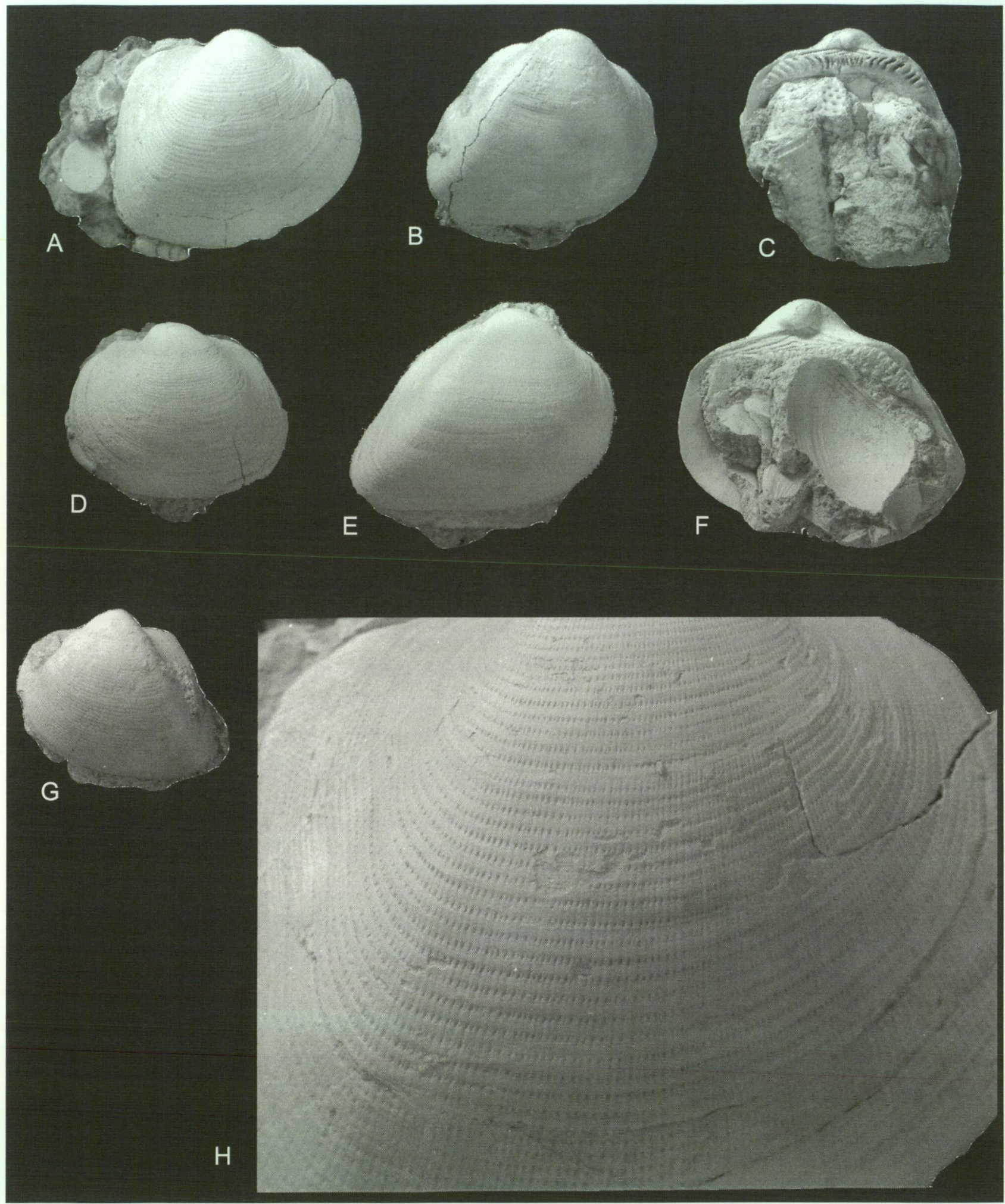

Figure 6 Trigonarca (Costelliarca) punctulata sp. nov. A ARI G2777/1, holotype, RV external x 1.5. B, C ARI G2777/2, paratype, RV external, internal x 1. D ARI G2777/4, paratype, LV external x 2. E ARI G2881/4, paratype, RV external x 1. F ARI G2881/5, paratype, RV internal x 1. G ARI G2881/1, paratype, LV external x 1 . H ARI G2777/1, holotype, RV external, enlarged to show punctation $\times 6$.

citing differences in shell proportions, probably from the figures. Our studies do not support Kossmat's reservations. One specimen of $T$. (C.) gamana from Locality 3 (G2880/3, an RV) has a large naticiform borehole located low on the umbo.

\section{Occurrence}

Uttattur Group. Pudur, Odiyam and Mungalpari (Stoliczka 1871: 354). Odiyam Localities 2 and 3. Karai Formation (Odiyam and Kunnam Members). Cenomanian. 
Trichinopoly Group. No locality given (Chiplonkar and Tapaswi 1976a: 220). Turonian Coniacian.

Ariyalur Group. "Pondicherry" (type). The precise source of Forbes' material is undetermined but may lie within the "Trigonarca beds" of Kossmat (1897), and Valudavur Formation (Rajagopalan 1965, Sundaram et al. 2001). Late Campanian-Maastrichtian.

\section{Trigonarca (Costelliarca) punctulata sp. nov. Figure $6 \mathrm{~A}-\mathrm{H}$}

\section{Material examined}

\section{Holotype}

ARI G2777/1, RV, from brown calcareous siltstone with abundant turritellid gastropods, beside track ca $0.5 \mathrm{~km}$ west of Odiyam village, Perambalur Taluk, Tiruchirapalli district, Tamil Nadu (=Locality 2 ).

\section{Paratypes}

ARI G2777/2-4, one LV, two RVs, Locality 2. G2881/1-7, one LV, six RVs, Locality 3. Total of 11 single valves.

\section{Other material}

ARI G2689, four LVs, two RVs, all juvenile, Odiyam Locality 1. G2773, one LV mould with shell remnants, Locality 2. G2881/8-10, three LVs, Locality 3. G2917/1, one juvenile LV, Locality 3. Total of 22 single valves.

\section{Diagnosis}

Medium-sized (length to $51 \mathrm{~mm}$ ), inflated Costelliarca; juvenile posteriorly truncated, more extended in maturity; beaks prosogyrate to orthogyrate; valves sculptured with very fine, close, radial costellae crossed by low, spaced, commarginal costellae, intercostal declivities so formed generating rows of fine punctae; radials not accentuated on postero-ventral shoulder and becoming obsolete with growth.

\section{Description}

Shell of medium size for subgenus, thick, robust, longer than high; when immature, roundly subquadrate and truncated posteriorly, becoming in adult more extended posteriorly, subtrapezoidal and subtrigonal; umbones inflated, moderately elevated above hinge margin, gibbous, prosogyrate; plane of greatest width posterior to beaks; beaks incurved, blunt, proximate and transgressing ligamental area, prosogyrate to orthogyrate, sometimes weakly sulcate on either valve; ligamental area narrowly lanceolate (juvenile) to broad (mature), usually either shortened posterior to beak or about equally disposed; posterior area broad, bordered by rounded shoulder which becomes more emphatic on mature shell; hinge margin straight, equal to or exceeding half total shell length; ventral margin slightly oblique to hinge margin, broadly convex; anterior margin convexly rounded; posterior margin truncate, obliquely so on mature specimens.

Sculpture of very fine, close, radial costellae over entire umbonal area and anterior flank, not accentuated on shoulder and weakening posteriorly; radials crossed by fine, low, spaced, commarginal costellae, extending over entire shell; intercostal declivities formed by intersection of radial and commarginal elements generate commarginal rows of minute punctae with subordinate radial alignment; both radial sculpture and punctae become obsolete, often abruptly, at ca $27 \mathrm{~mm}$ of growth on LV and ca $20-23 \mathrm{~mm}$ on RV (on some specimens, more gradually), giving way to simple commarginal growth striae extending to margin; single narrow radial rib may occur centrally on posterior area of RV.

Hinge plate broad (mature), descending at each end, more so posteriorly; teeth massive (mature), continuous, in three well-defined series, anterior numbering seven or eight, oblique, proximal three falcate; median series about ten, short, crowded, vertical; posterior series ten, oblique, proximal five falcate; all teeth convergent to point well below beak; anterior adductor scar lozenge-shaped, acuminate dorsally, located immediately below end of hinge plate; posterior adductor scar rectangular, located below end of hinge plate upon low myophoric flange; pallial line entire, marginal to body cavity and bordered within by row of short, radial grooves, which are strongest posteroventrally; ventral margin smooth, on $L V$ bevelled and with low ridge to receive margin of $R V$.

Dimensions of Trigonarca (Costelliarca) punctulata sp. nov.

\begin{tabular}{llccc}
\hline Specimens & Length & Height & L/H & Inflation \\
\hline $\begin{array}{l}\text { ARI G2777/1, } \\
\text { RV, holotype }\end{array}$ & 27.66 & 23.90 & 1.15 & 9.48 \\
$\begin{array}{l}\text { ARI G2777/2, } \\
\text { RV, paratype }\end{array}$ & 39.7 (est.) & 33.32 & 1.19 & 15.23 \\
$\begin{array}{l}\text { ARI G2777/3, } \\
\text { RV, paratype }\end{array}$ & 28.26 & 23.36 & 1.25 & 9.51 \\
$\begin{array}{l}\text { ARI G2777/4, } \\
\text { LV, paratype }\end{array}$ & 18.78 & 15.42 & 1.21 & 7.57 \\
$\begin{array}{l}\text { ARI G2881/1, } \\
\text { LV, paratype }\end{array}$ & 32.98 & 26.61 & 1.23 & 13.71 \\
$\begin{array}{l}\text { ARI G2881/2, } \\
\text { RV, paratype }\end{array}$ & 32.66 & 25.48 & 1.28 & 10.66 \\
$\begin{array}{l}\text { ARI G2881/4, } \\
\text { RV, paratype }\end{array}$ & 45 (est.) $^{*}$ & 33.62 & 1.33 & 20.1 (est.) \\
$\begin{array}{l}\text { ARI G2881/5, } \\
\text { RV, paratype }\end{array}$ & 51 (est.) $^{* *}$ & 38.82 & 1.31 & 21.86 \\
\hline
\end{tabular}

* specimen slightly damaged anteriorly

** largest specimen, damaged anteriorly and posteriorly 


\section{Remarks}

Observed variation in the present species concerns mainly shell proportions and sculpture. Juvenile and some immature specimens (e.g., G2777/1, G2777/4) are subquadrate and truncated posteriorly, with a broadly rounded shoulder and are covered entirely with punctate microsculpture. With growth, the posterior becomes more extended and subtrigonal, shoulder more or less roundly subangular and the radial/punctate elements of the sculpture tend to disappear, either gradually or abruptly. These changes we interpret as recording a juvenile stage of byssal attachment (from the presence of the sulcate beaks) with a well-developed periostracum (shown by the surface punctation), the subsequent adult stage corresponding to a nestling, shallow-burrowing habit on a coarse grained, somewhat energised and unstable substrate. Shell length to height ratios of $<1.35$ (see Thomas 1978a, b) and the absence of conjoined pairs in the study material are consistent with this interpretation.

The holotype of Trigonarca (Costelliarca) punctulata is pre-adult and in life was probably byssate. It shows well the salient diagnostic character of the species-fine, punctate microsculpture. The paratype series demonstrates the transition to adult form, sculpture and presumed life habit aforementioned. Having only single valves, we have not been able to establish the precise degree of any valve discrepancy, such as occurs in associated species of the subgenus. However, radial sculpture and punctae appear to be more persistent on the $L V$, which also may be a little larger than the RV.

The new species differs from other south Indian species of Costelliarca by its combination of greater inflation, punctate microsculpture and absence of accentuated radials on the posterior shoulder. From T. (C.) pusilla Nayak and Badve (Bagh Beds, Turonian), it differs in a more centrally located umbone, greater height relative to length and less carinate posterior shoulder (Nayak and Badve 1985). This record establishes the presence of three species of Costelliarca in the Karai Formation and eight species in the Cretaceous of the Cauvery Basin.

\section{Etymology}

From the Latin punctulum, a small hole, dot or point, after the microsculpture.

\section{Occurrence}

Uttattur Group. Odiyam Localities 1, 2 (type) and 3. Karai Formation (Odiyam and Kunnam Members). Cenomanian.

\section{Superfamily Limopsoidea Dall, 1895}

$$
\text { Family Limopsidae Dall, } 1895
$$

Genus Limopsis Sassi, 1827

\section{Type species}

Arca aurita Brocchi, 1814. Pliocene-Recent, N Atlantic-Mediterranean. By original designation.

\section{Limopsis coemansi Briart and Cornet, 1868 Figure $7 \mathrm{~A}-\mathrm{C}$}

1868 Limopsis coemansi Briart and Cornet: 4, 60, pl. 6, figs 10, 11 .

1899 Limopsis albiensis Woods: 71, 99, pl. 15, figs $1-4$.

1939 Limopsis coemansi Briart and Cornet; Marlière: 28-31, pl. 1, figs $16 \mathrm{a}-\mathrm{d}$, text figs 5, 6 . Synonymy.

\section{Material examined}

ARI G2690, 16 LVs, 23 RVs, one pair, Locality 1; G2765, 14 LVs, 12 RVs, one pair, Locality 2; G2883, two LVs, one RV, Locality 3 . Total of 70 specimens (south India).

\section{Diagnosis}

Small, length to six mm, inflated, subtrapezoidal with narrow, slightly arched hinge plate; sculpture light, mainly commarginal with very faint radial costellae extending from posterior area; margin smooth.

\section{Description}

Shell small for genus, inflated, roundly subtrapezoidal, slightly extended posteriorly; length and height approximate; umbones prominent, broadly inflated, prosogyrate, located just anterior of centre; posterior area slightly alate, offset from disc by broadly rounded shoulder; ligamental area narrowly elliptical, smooth, extended posteriorly and bordered by thin thread; resilifer small, triangular, below beak; hinge margin very slightly arched, extended posteriorly, length almost equal to half shell length; anterior margin convexly rounded, merging evenly into ventral margin; posterior margin obliquely truncate, subangulate dorsally and rounded ventrally; hinge plate narrow, slightly arched; hinge asymmetric with projecting teeth, ca five in anterior series, six in more extended posterior series; anterior teeth more or less parallel, subvertical; posterior teeth oblique, convergent to point well below beak, distal teeth subparallel to hinge margin; ventral margin internally bevelled, smooth.

Sculpture faint, of obscure commarginal costellae across disc, scarcely or not discernible on juveniles; 


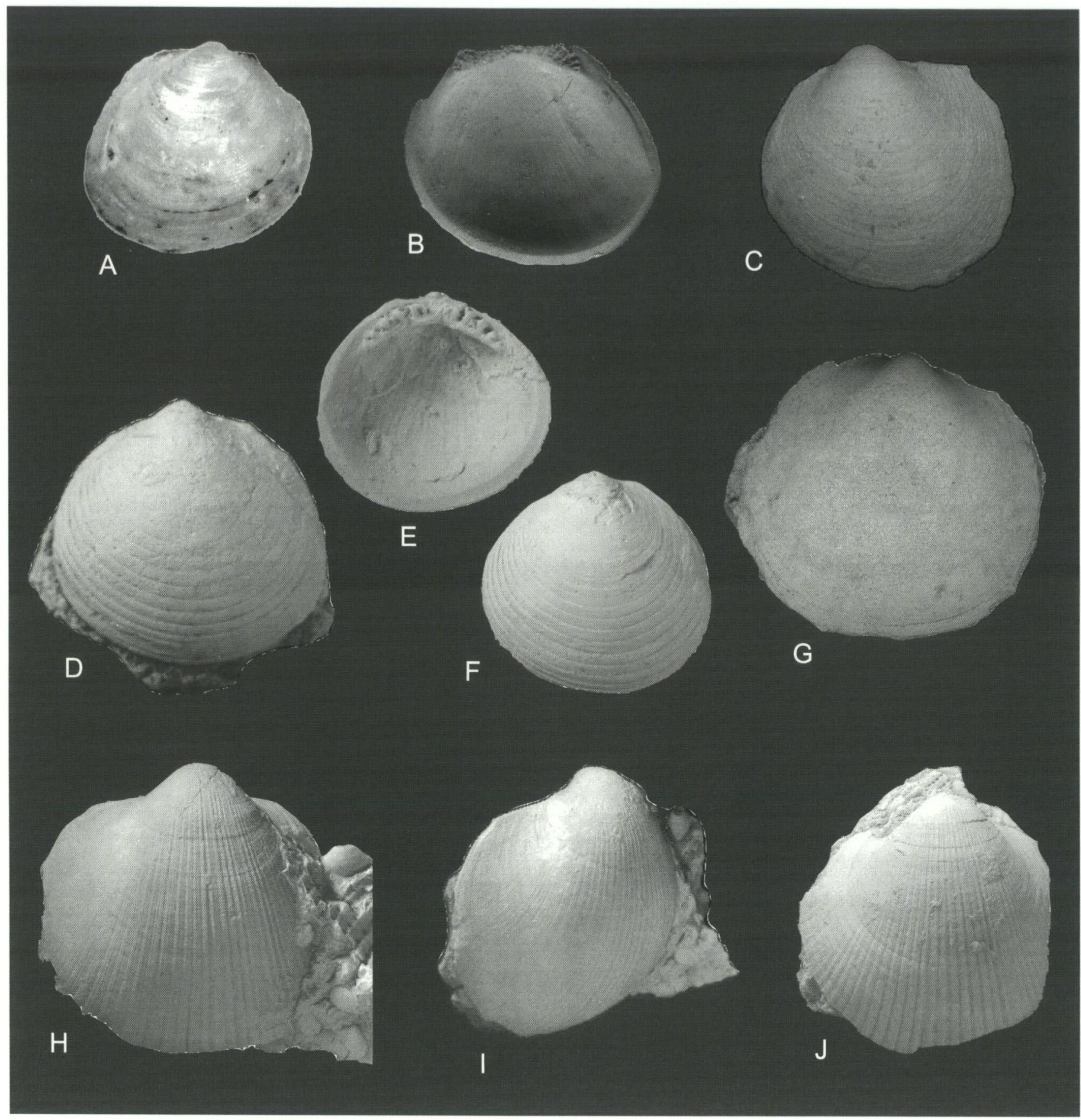

Figure 7 Limopsis coemansi Briart and Cornet. A, B ARI G2765/1, RV external, internal x 8. C ARI G2765/2, LV external x 12. Limopsis sp. A. D ARI G2691/1, LV external x 10. E, F ARI G2786/2, LV internal, external x 10. Limopsis sp. B. G ARI G2767, RV external x 12. Glycymerita cardioides (d'Orbigny). H, I ARI G2768/2, LV external (I showing anterior flank) x 2. J ARI G2768/1, LV external showing anterior flank x 1.5.

Dimensions of Limopsis (L.) coemansi Briart and Cornet.

\begin{tabular}{lcccc}
\hline Specimens & Length & $\begin{array}{c}\text { Length } \\
\text { hinge } \\
\text { margin }\end{array}$ & Height & Inflation \\
& \multicolumn{4}{c}{. } \\
\hline ARI G2765/1, RV & 5.16 & 2.58 & 4.88 & 1.82 \\
ARI G2765/2, LV & 5.66 & 2.76 & 5.50 & 1.85 \\
ARI G2765/3, LV & 4.82 & 2.32 & 5.08 & 1.87 \\
ARI G2765/4, LV & 4.74 & 2.28 & 4.53 & 1.10 \\
\hline
\end{tabular}

faint radial costellae, visible in oblique light, present on posterior area, sometimes extending as very fine striae to median disc; adductor scars lightly impressed, posterior larger; pallial line broad, entire.

\section{Remarks}

Odiyam material has been compared with topotypes of Limopsis coemansi Briart and Cornet from the Upper Albian Meule de Bracquegnies, 
Belgium, in the collection of the Koninklijk Belgisch Instituut voor Natuurwetenschappen, Brussels, and we conclude that they are conspecific. Specimens from Odiyam Locality 2 (G2765) are a particularly close match. Variation in the study material concerns mainly the degree of inflation (see Dimensions) and the strength and persistence of the radial micro-sculpture. Most specimens show several faint radial striae on the posterior slope, visible in oblique light; occasionally these may extend as faintly incised striae to the central disc. Marlière (1939: 28) reports very fine radial microsculpture on specimens of $L$. coemansi from the Meule de Bracquegnies of Hainault, Belgium. Specimen G2765/5 shows clear radial costellae on the posterior slope, which, though very faint, recall those characteristic of the genus or subgenus Pectunculina d'Orbigny; however, the margins of this and all other specimens to hand lack crenulation.

Surprisingly, the Limopsidae have not been recorded hitherto from the Cretaceous of south India (Tapaswi 1987) and the presence of three species (one common, two rare, see below) in the Karai Formation suggests that others may occur higher in the Cauvery Basin succession. From its associated south Indian congenors, Limopsis coemansi may be distinguished by its thinner, usually more inflated and oblique shell, extended, almost straight postero-dorsal margin and radial microsculpture. In its slightly asymmetric, inflated shell, extended a little posteriorly, narrow hinge plate and faint microsculpture, the present species shows some resemblance to $L$. meeki Wade (see Wade 1926, pl. 10, fig. 5) from the Maastrichtian Ripley Formation of Coon Creek, Tennessee, differing in its shorter, more delicate hinge and more evident radials. One valve only in the study material (G2690, Locality 1) shows a gastropod borehole.

\section{Occurrence}

Europe: Hainault (type), Belgium; Folkestone, England. Middle to Late Albian. India: Uttattur Group. Odiyam Localities 1,2 and 3. Karai Formation (Odiyam and Kunnam Members). Cenomanian.

\section{Limopsis species A \\ Figure $7 \mathrm{D}-\mathrm{F}$}

\section{Material examined}

ARI G2691, four LVs, four RVs, Locality 1; G2766, one LV, one RV, Locality 2; G2786, three LVs, Locality 2 . Total of 13 single valves.

\section{Description}

Shell small for genus, length to nine $\mathrm{mm}$, possibly immature; slightly longer than high, obliquely suborbicular with weakly defined posterior area; moderately robust and inflated; umbones broad, orthogyrate; beaks acuminate, slightly elevated and anterior of centre, orthogyrate; ligamental area short, narrow, smooth apart from small, central, triangular resilifer; umbones smooth for first $3 \mathrm{~mm}$ of growth, thereafter sculpture of low, more or less regular commarginal costellae, about 15 over height of $3.6 \mathrm{~mm}$ and with linear interspaces; radial sculpture absent.

Hinge plate robust, arched, teeth in two series, almost symmetrical about beak; posterior series slightly longer and exceeding by one those of anterior series; adductor scars high beneath hinge plate, each bordered along inner edge by low ridge; posterior scar larger, subrounded, slightly higher than wide; ventral margin smooth, bevelled; body cavity finely radially striate.

Dimensions of Limopsis sp. A.

\begin{tabular}{lccc}
\hline Specimens & Length & Height & Inflation \\
\hline ARI G2691/1, LV & 4.40 & 4.20 & 1.28 \\
ARI G2766/1, LV & 8.72 & 7.93 & 2.23 \\
ARI G2766/2, RV & 9.01 & $8.6($ est.) & 2.32 \\
ARI G2786/1, LV & 4.78 & 4.60 & 1.44 \\
\hline
\end{tabular}

*beak damaged

\section{Remarks}

The identities of this and the following species have yet to be fully determined; however both appear to be distinct from all of the European Cretaceous species of Limopsis in Woods (1899: 71, 72 ) and the associated $L$. coemansi Briart and Cornet. Most of the specimens to hand are juveniles and all of the larger, possible adult examples $(G 2766 / 1,2)$ are unsuitable for selection as type material. Further determination of this second species of Limopsis from the Karai Formation awaits the collection of better preserved specimens.

\section{Occurrence}

Uttattur Group. Odiyam Localities 1 and 2. Karai Formation (Odiyam and Kunnam Members). Cenomanian.

\section{Limopsis species B}

Figure $7 \mathrm{G}$

\section{Material examined}

ARI G2692, one LV, Locality 1; G2767, one LV, Locality 2. Two single valves, both probably juvenile.

\section{Description}

Shell very small, length to $4 \mathrm{~mm}$, about as long as high, suborbicular, compressed; umbones broad, 
low; beaks acute, incurved, barely transgressing ligamental area, slightly anterior of centre and probably slightly prosogyrate; ligamental area moderately broad, smooth and with small triangular resilifer below beak; hinge plate and teeth mostly obscured; sculpture of faint commarginal growth lines and several obscure commarginal costellae; surface polished, without radial sculpture; ventral margin smooth, internally bevelled; interior obscured.

Dimensions of Limopsis sp. B.

\begin{tabular}{lccc}
\hline Specimens & Length & Height & Inflation \\
\hline ARI G2692, LV & 3.07 (est.) $^{*}$ & 3.04 & 0.80 (est.) \\
ARI G2767, LV & 4.26 & 4.18 (est.) $^{*}$ & 0.88 \\
\hline
\end{tabular}

* slightly damaged

\section{Remarks}

In its compressed, suborbicular form and smooth exterior (i.e., no radials), the present species shows some resemblance to Limopsis maggae Heinberg from the Maastrichtian Danish Whitechalk (Heinberg 1979: 105, 106, fig. 1). The ligamental area seems to be wider in the Odiyam species. From its congenors in the Karai Formation, Limopsis species $B$ may be distinguished by the following combination of characters-compressed form, relatively wide ligamental area, more acute beak and near-absence of sculpture. Mature specimens are needed to establish an identity for this species.

\section{Occurrence}

Uttattur Group. Odiyam Localities 1 and 2. Karai Formation (Odiyam and Kunnam Members). Cenomanian. Rare.

\section{Family Glycymeridae Newton, 1916}

\section{Remarks}

Tschudin (2001: 667) argues for the retention of the "original, linguistically more correct spelling Glycymeridae" of Newton (1916), contrary to the formulation Glycymerididae adopted by Stenzel et al. (1957).

\section{Genus Glycymerita Finlay and Marwick, 1937}

\section{Type species}

Glycymeris concava Marshall, 1917, by original designation. Early Paleocene, New Zealand.

\section{Subgenus Glycymerita s. str}

\section{Remarks}

Full generic rank is accorded to Glycymerita by
Beu and Maxwell (1990: 78, pl. 1, figs e, h), who redescribe and refigure the type and other species of the genus from the New Zealand Cenozoic. Salient generic features are: robust glycymerids of up to moderately large size and subquadrate form, with prominent, strongly inflated umbones; radial costellae of anterior and posterior flanks narrow and rounded; elsewhere, costae flattened and with well defined edges; hinge configuration variable, some with teeth subhorizontal toward extremities; margin strongly crenulate. The genus ranges from the Neocomian of France (Nicol 1950) to the Late Pliocene (Waipipian) of New Zealand (Beu and Maxwell 1990).

\section{Glycymerita (Glycymerita) cardioides (d'Orbigny, 1847) \\ Figure $7 \mathrm{H}-\mathrm{J}$}

1847 Arca cardioides d'Orbigny, pl. 4, figs 35, 36.

1871 Axinaea cardioides (d'Orbigny); Stoliczka: 349, pl. 17 , figs $33,33 a, 33$ b; pl. 50 , fig. 8 .

1897 Axinea [sic] cardioides (d'Orbigny); Kossmat: 65.

1987 Glycymeris (Glycymerita) cardioides (d'Orbigny); Tapaswi: 506. List only.

\section{Material examined}

GSI Stoliczka Collection 1189, RV from "Odium". ARI G2693, one LV, one RV (juveniles), Odiyam Locality 1; G2768, four LVs, two RVs, Locality 2. Total of ten single valves. The type of Arca cardioides d'Orbigny was not located at the Museum National d'Histoire Naturelle, Paris (A. Lauriat-Rage, personal communication, 28 October 1997) and its location remains unknown.

\section{Provisional Diagnosis}

Medium-sized Glycymerita s. str., length to 41 $\mathrm{mm}$, with tumid, elevated umbones; sculpture (post-juvenile) in five segmental areas: (i) anterior flank with fine, close, rounded costellae, becoming (ii) aggregated into uneven, composite costae extending to about midline, passing into (iii) broad, flat, simple costae with narrow interspaces, then (iv) narrow costae with sharp crests and wide interspaces and (v) on posterior slope, costellae similar to those on anterior flank (i).

\section{Description}

Study material (Odiyam) small for species, no specimen fully mature. Shell roundly subquadrate, slightly longer than high; umbones tumid, elevated, slightly posterior of midline, more or less orthogyrate; beaks incurved, acute, orthogyrate to slightly opisthogyrate, transgressing slightly ligamental area and located slightly posterior of 
centre; dorsal margin extended, shouldered at each end, length about three fifths that of shell; anterior margin roundly subtruncate; ventral margin broadly and evenly rounded; posterior margin mostly obscured or damaged but probably subtruncate, not extended; ligamental area apparently narrowly lanceolate, it and hinge plate being mostly concealed; teeth robust, anterior series subhorizontally aligned toward extremity; sculpture of numerous fine to very fine radials, differentiated into five segments: (i) anterior flank with very fine, close, rounded costellae, more prominent toward disc and becoming (ii) aggregated into about nine, fine, uneven composite costae, each comprising up to four costellae with single costella in interspaces and extending to about midline, then (iii) about seven, broad, flat, simple costae (occasionally bifurcate) with narrower interspaces, then (iv) six narrow costae with sharp crests and wider interspaces, along posterior shoulder, then (v) on posterior flank, about ten fine, close, subordinate, commarginal striae extending across entire surface; ventral margin internally crenulate, spacing corresponding to that of primary radial sculpture; internal characters undetermined.

Dimensions of Glycymerita cardioides (d'Orbigny).

\begin{tabular}{lcccc}
\hline Specimens & Length & $\begin{array}{c}\text { Length } \\
\text { hinge } \\
\text { margin }\end{array}$ & Height & Inflation \\
\hline GSI 1189, RV & 41.06 & ca 21.1 & 38.32 & 16.46 \\
ARI G2768/1, LV & -* $^{*}$ & - & 28.02 (est.) & 12.3 (est.) \\
ARI G2768/2, LV & 24.4 (est.) & 15 & 22.82 & 9.42 \\
\hline
\end{tabular}

* broken posteriorly

\section{Remarks}

Our material has been compared with GSI Stoliczka Collection no. 1189, a large, probably gerontic, worn RV in brown, very coarse-grained, gritty sandstone from "Odium", apparently that figured by Stoliczka (1871, pl. 17, figs 33, 33a, 33b). It is roundly subquadrate, scarcely extended posteriorly; ligamental area broad, symmetrical about beak; sculpture mostly worn, of ca 37 discernible radials of which anterior are composite, i.e., of aggregated costellae; flanks smooth to very finely radially striated; posterior teeth subhorizontal. The five-part arrangement of radials visible on the ARI material appears to have been lost on GSI 1189 by abrasion and/or weathering but the specimen agrees in proportions with the study material, differing only in size and we consider them to be conspecific.

According to Stoliczka (1871), d'Orbigny's (1847) type and figured specimen of Arca cardioides is a "comparatively very inequilateral and oblique specimen from Pondicherry" [i.e., Ariyalur Group, Maastrichtian] "we have exactly similar specimens from Ootatoor and Odium". One such is depicted in Stoliczka's pl. L, fig. 8. Another from the "Trichinopoly Group" of Saradamangalam, possibly Anaipadi Formation, Turonian-Coniacian, is said to be "less produced posteriorly" with wider intercostal spaces. Neither of these specimens has been located by us in the GSI Stoliczka Collection, Kolkata. These few diverse records were accepted by Stoliczka (1871) as representing a single, variable, long-ranging (?Albian - Cenomanian Maastrichtian) species, a conclusion that remains subject to confirmation from a wider range of material, particularly from the type area.

Kossmat (1897: 65) expressed reservations about the validity of records of long-ranging species of bivalves and gastropods, including the present species [as Axinea cardioides d'Orb.], "said to occur in both the Ariyalur and Utatur stages of the Trichinopoli district". Kossmat's view of this may have arisen from an appreciation of the rapidly evolving ammonite lineages of the Late Cretaceous, characterised by a faster turnover of morphospecies, compared with the more speciose and sometimes more stable bivalve and gastropod lineages. In the present example, the issue cannot be resolved with certainty from the limited available material.

The present species differs from Glycymerita subplanata (Stoliczka), G. levicula (Stoliczka), G. subauriculata (Stoliczka) and G. altiuscula (Stoliczka), all Ariyalur Group, by its well developed radial sculpture; from $G$. griesbachi (Newton), Upper Albian of Zululand, by its more elevated umbones and stronger radial sculpture.

\section{Occurrence}

Uttattur Group. "Ootatoor and Odium" (Stoliczka 1871). Karai Formation. Stoliczka's record from Uttattur may be of Late Albian age; his specimen from Odiyam is presumably Cenomanian. Odiyam Localities 1 and 2. Karai Formation (Odiyam and Kunnam Members). Cenomanian.

Trichinopoly Group. Saradamangalam (Stoliczka 1871). Anaipadi Formation. Turonian - Coniacian.

Ariyalur Group. Pondicherry (type). Valudavur or Mettuveli Formations. Maastrichtian. Uncommon.

\section{Order Pterioida Newell, 1965 [emend. Waller, 1978]}

\section{Superfamily Inoceramoidea Giebel, 1852}

\section{Remarks}

From considerations of ligamental form and function, an alternative location for the Inoceramoidea (as redefined) in the Subclass Cryptodonta Neumayer, 1884 has been proposed by Johnston and Collom (1998). 
Family Inoceramidae Giebel, 1852

Genus Inoceramus J. Sowerby, 1814

Type species

Inoceramus cuvieri J. Sowerby, 1814, by monotypy. Cenomanian-Turonian, England. I.C.Z.N. (1957), Opinion 473.

\section{Subgenus Inoceramus s. str}

\section{Inoceramus (Inoceramus) pictus J. Sowerby, 1829} Figure $8 \mathrm{~A}$

1829 Inoceramus pictus J. Sowerby 4: 215, pl. 604.

1911 Inoceramus pictus J. Sowerby; Woods: 279, 280, pl. 49, figs 5, 6 .

1973 Inoceramus pictus Sowerby. Chiplonkar and Badve: 7 , tab. 2.

1976 Inoceramus pictus Sowerby. Chiplonkar and Tapaswi 1976b: 110.

1979 Inoceramus pictus Sowerby; Chiplonkar and Tapaswi: 139, 144-6, 157, 163.

1981 Inoceramus pictus Sowerby; Crame: 34-41, figs 3-6.

1987 Inoceramus (I.) pictus Sowerby; Tapaswi: 507. List only.

\section{Material examined}

ARI G2887, one LV, Locality 3.

\section{Description}

Medium-sized LV, thin shelled, subovate, height exceeding length, inflated, with prominent elevated, tumid umbone; slightly prosogyrate; umbonal angle ca $70^{\circ}$; beak acuminate, strongly incurved, prosogyrate; anterior margin and area retained dorsally, slightly concave; ventral margin missing or obscured; posterior margin, area, hinge and interior all obscured; sculpture of numerous low, rounded, subequal, commarginal costae, slightly wider than interspaces, confined to median area and numbering ca 42 in height of $48 \mathrm{~mm}$ (measured from dorsal extremity); no second order sculpture; apical area smooth (? decorticated); anterior flank bordered by faint groove, smooth apart from several weak radial striae.

Dimensions of Inoceramus (I.) pictus Sowerby.

\begin{tabular}{llll}
\hline Specimen & Length & Height & Inflation \\
\hline ARI G2887, LV & 50 (est.) & 75 (est.) & 22 (est.) \\
\hline
\end{tabular}

\section{Remarks}

Inoceramus pictus J. Sowerby is a wide-ranging, at times near-cosmopolitan species of the Middle
Cenomanian (Turrilites acutus Zone) to Early Turonian (Watinoceras coloradoense Zone), characterised by considerable morphological variation between and within single-locality samples (Crame 1981, Tröger 1989, Dhondt 1992). A number of subspecies have been erected within this taxon but the poor preservation of the present single specimen precludes confident assignment to any of these. In N America and Antarctica, Inoceramus pictus appears to be confined to the Late Cenomanian (Crame 1981, Hancock 2000), whereas in the $N$ European-Tethyan areas, extending to Madagascar and India, a Middle Cenomanian-Early Turonian age is recognised (Heinz 1933, Kauffmann 1973, Tröger 1989).

Chiplonkar and Tapaswi (1975a) reported Inoceramus pictus from the "upper part of the Uttattur and lower part of Trichinopoly Group", corresponding to the Karai and Kulakkalnattam Formations respectively. A Late Cenomanian Early Turonian time-range for these records seems likely. Ayyasami and Banerji (1984) have recorded I. pictus from limestones of the Karai Formation east and north-east of Odiyam in proximity to occurrences of the ammonite Eucalycoceras pentagonum (Jukes-Brown and Hill) and stratigraphically a little below the CenomanianTuronian transition. A Late Cenomanian age for those records of I. pictus (within the Eucalycoceras pentagonum Zone) is thus confirmed. The shelly limestone from Odiyam Locality 3, source of the present specimen, overlies a sandstone unit containing the ammonite Calycoceras newboldi Kossmat, a Middle Cenomanian index species (Sastry et al. 1968, Ayyasami and Banerji 1984) and is thus consistent with a Late Cenomanian age for material from that source (Locality 3 ). Inoceramus pictus pictus is restricted to the Late Cenomanian (Crame 1981 and references).

Chiplonkar and Badve (1976) reported Inoceramus pictus from the Middle and Upper Nodular Limestones, Bagh Beds of the lower Narmada valley, within the unspecified time range of Cenomanian-Turonian. From the base of the same Nodular Limestones, the authors described Inoceramus pronus, not dissimilar from $I$. pictus but comparatively more compressed, with fewer, stronger and more spaced ribs.

\section{Occurrence (India)}

Uttattur Group. East and north-east of Odiyam (Ayyasami and Banerji 1984). Karai Formation (Kunnam Member). Late Cenomanian. Odiyam Locality 3 (rare). Karai Formation (Kunnam Member). Late Cenomanian. "Upper part of Utatur and lower part of Trichinopoly Group" (Chiplonkar and Tapaswi 1974, 1975a). Karai Formation (Kunnam Member). Late Cenomanian: Kulakkalnattam Formation. Early Turonian. Lower 
Narmada valley, Middle and Upper Nodular Limestones, Bagh Beds. Cenomanian - Turonian.

\section{Superfamily Pinnoidea Leach, 1819}

Family Pinnidae Leach, 1819

Genus Pinna Linnaeus, 1758

\section{Type species}

Pinna rudis Linnaeus, 1758 , by subsequent designation of Children 1823. Recent, N Atlantic.

\section{Pinna sp.}

\section{Material examined}

ARI G2694, one incomplete pair, Locality 1.

\section{Description}

Conjoined valves, small for genus, possibly immature, lacking anterior third of both valves, ventral portion of $L V$ and most or all of outer layer; valves strongly convex though apparently not carinate, conjoined along dorsal margin; height exceeds width; cross section ovate; no apparent gape; dorso-ventral profile evenly tapered, subtending angle of ca $28^{\circ}$; remnant of near-outer layer on dorsal area of LV bears 11 narrow, slightly irregular, radial costae with wide interspaces; commarginal sculpture faint, probably from decortication; internal mould of RV shows on median area two shallow, spaced, radial grooves, corresponding to low ridges on interior of valve.

\section{Dimensions}

Actual length $87 \mathrm{~mm}$; estimated original length up to ca $130 \mathrm{~mm}$. At fractured anterior end, height is $21.4 \mathrm{~mm}$, width $20.2 \mathrm{~mm}$.

\section{Remarks}

Stoliczka (1871: 385) recorded two species of Pinna from the Uttattur Group but the poor condition of the present material precludes assignment to either of these. $P$. intumescens Stoliczka (type locality "Odium, in earthy limestone") is based on two internal moulds, showing "on the internal side of the shell a deep depression, marked on the cast by an elevated ridge". These features cannot be matched on our specimen. The external characters of $P$. intumescens remain unknown.

Pinna laticostata Stoliczka was erected on material from the Ariyalur and Uttattur Groups; figured specimens (Stoliczka 1871, pl. 25, figs 2, 3; pl. 26, fig. 4) were from "Coomarapolliam" in the former group. The remnant of near-external shell layer on the Locality 1 specimen is sculptured not unlike that of $P$. laticostata but is confined to the dorsal LV. The loss of the original outermost surface has almost totally removed any commarginal sculpture. From the Uttattur Group, Stoliczka (1871) had only one fragment attributable to $P$. laticostata, part of "a large specimen with the shell surface well preserved". This specimen, collected from Uttattur, was not located by Lakshminarayana et al. (1976: 178). Thus, the species of Pinnidae from the Uttattur Group remain poorly known.

Lakshminarayana et al. (1976: 177) have drawn attention to the incorrect caption to Stoliczka's (1871) pl. 26, fig. 4, whereby a specimen of Pinna laticostata from the Ariyalur Group is referred to as "Pinna latisulcata Stol.". A label accompanying the specimen (GSI 1267) is said by them to bear that name. "Pinna latisulcata Stol." is an uncorrected lapsus calami and the combination is a nomen nudum. A perusal of text and index of Stoliczka's monograph reveals no other usage of the combination "Pinna latisulcata", contrary to the assertion of Lakshminarayana et al. (1976: 177) that it appears, attributed to Woodward, on Stoliczka's p. 385, Items 2-24. This is not so. Stoliczka's listing of the Cretaceous species of Pinna is on pages 383 and 384 and on neither page does the name Pinna latisulcata occur. The present specimen, one of very few known examples of Pinna from the Uttattur Group, is too poorly preserved for specific determination.

\section{Occurrence}

Uttattur Group. Odiyam Locality 1. Karai Formation (Kunnam Member). Cenomanian. Rare.

\section{Order Limoida Waller, 1978}

\section{Superfamily Limoidea Rafinesque, 1815}

Family Limidae Rafinesque, 1815

Genus Limatula Wood, 1839

\section{Type species}

Pecten subauriculata Montagu, 1808, by subsequent designation of Gray 1847. Recent, N Atlantic.

\section{Remarks}

The genus Limatula and subgenera, both modern and fossil, including Indian species from the Jurassic of Kutch, have been reviewed by Fleming (1978) though without reference to Stoliczka's species. From its elongate, slightly oblique form and simple radial sculpture, confined essentially to the median area, $L$. persimilis appears to be referrable to Limatula s. str.

\section{Limatula persimilis (Stoliczka, 1871) Figure 8 B, C}

1871 Radula (Limatula) persimilis Stoliczka: 420, pl. 29 , figs 4,5 . 
1987 Limatula persimilis (Stoliczka); Tapaswi: 509 List only.

\section{Material examined}

\section{Lectotype}

Here designated. GSI Stoliczka Collection 1285, LV, Kullay. Paralectotype GSI Stoliczka Collection 1284, RV, "Poothoor".

\section{Other material}

ARI G2695, one LV (juvenile), two incomplete valves, one an RV (both interiors only), one LV internal mould, Locality 1; G2772, one LV interior, one LV internal mould, one RV, Locality 2; G2833, one incomplete LV interior, Locality 2; G2957, two fragmentary RVs, Locality 3 . Total of ten single valves.

\section{Diagnosis}

Medium-sized Limatula, length to $26 \mathrm{~mm}$, with 15-20 fine radial costellae, smooth and triangular in cross section, slightly narrower than interspaces; ligamental pit large, asymmetric, extended anteriorly slightly.

\section{Description}

Study material all either juvenile, immature or fragmentary single valves or moulds. Thin, fragile, higher than long (ratio 1.3 to 1.8), slightly extended anteriorly; umbones narrowly inflated, opisthogyrate, projecting slightly above dorsal margin; beaks incurved, orthogyrate, not transgressing narrowly elliptical cardinal area; ligamental pit large, shallow, occupying one third area and slightly extended anteriorly; auricles small, subequal; dorsal margin slightly arched, edentulous, occasionally with two weak dysodont teeth at each extremity; anterior margin slightly extended, broadly rounded, posterior margin less so; ventral margin short and convexly rounded; sculpture of ca 18 radial costellae on median area, slightly narrower than interspaces and more or less smooth; obscure radial threads on anterior flank, posterior flank smooth; faint growth striae cross flanks and crowd intercostal spaces of median area; ventral margin crenulate, corresponding to radial sculpture; adductor scar large, subcircular, very faint and centred in posterodorsal quadrant; weak radial ridges and grooves mark internal median area.

Dimensions of Limatula persimilis (Stoliczka).

\begin{tabular}{lccc}
\hline Specimens & Length & Height & Inflation \\
\hline GSI 1285, LV, lectotype & 26.37 & 43.00 & 13 (est.) \\
GSI 1284, RV, paralectotype & 24.96 & 33.95 & 12 (est.) \\
ARI G2695/4, LV & 3.32 & 5.21 & 1.60 \\
ARI G2772/1, LV & 7 (est.) & $>10$ (est.) & - \\
ARI G2957/2, RV & 10 (est.) & 19.6 (est.) & 5.2 \\
\hline
\end{tabular}

\section{Remarks}

The study material from Odiyam has been compared with Stoliczka's (1871) original specimens of Radula (Limatula) persimilis, which are GSI nos 1284 and 1285 , the former an RV from "Poothoor" [=Pudur], the latter an LV from Kullay. Each is of mature size, has 18 radials on the median area, a few obscure threads on the anterior flank and a smooth posterior flank; radials tend to be narrower than interspaces. The Odiyam specimens lack the obliquity of Stoliczka's, possibly because of immaturity. GSI Stoliczka Collection no. 1285 from Kullay (figured Stoliczka 1871, pl. 29, fig. 5, 5a) we designate to be lectotype of Radula (Limatula) persimilis Stoliczka and GSI Stoliczka Collection no. 1284 from "Poothoor" [=Pudur] (figured pl. 29, fig. 4, 4a) thus becomes paralectotype of that species.

Variation in the present species is not clear due to the few available specimens and the poor condition of most. Stoliczka cited rib counts of 15-20, varying directly with size. However ARI no. G2695/4 is a juvenile with ca 20 costellae and traces of radial threads on both flanks. The dimensions indicate some variation in the height/width ratio. Specimen G2833 (Figure $8 \mathrm{C}$ ), a fragmentary $\mathrm{LV}$ interior from Locality 2 , is included with reservation in the present species in view of its unique, well developed internal radial sculpture. It may represent a second species of Limatula in the Karai Formation, something to be clarified by further collection.

Limatula persimilis is the sole species of the genus currently on record from the Cretaceous of south India. A related congenor is $L$. fittoni (d'Orbigny) from the English Upper Greensand and Belgian Meule de Bracquegnies, ranging from Late Albian to Early Cenomanian (Marlière 1939: 86-88, pl. 5, fig. 11). In comparison, L. persimilis tends to have more ribs, which are more spaced and smooth, lacking the weak spinulosity of d'Orbigny's species. Ayyasami and Jagannatha Rao (1979) recorded $L$. persimilis from beds west of Kallakkudi (near Dalmiapuram), re-assigned by them to the Uttattur Group, previously included by Blanford (1862) in the Trichinopoly Group. These evidently represent an isolated exposure of Karai Formation (Sundaram et al. 2001, fig. 3).

\section{Occurrence}

Uttattur Group. Near Pudur and Kullay (type) in a yellowish brown limestone and north of Odiyam in a brown sandy limestone (Stoliczka 1871). West of Kallakkudi (Ayyasami and Jagannatha Rao 1979); Odiyam Localities 1, 2 and 3. All Karai Formation (Odiyam and Kunnam Members). Cenomanian. Uncommon. 

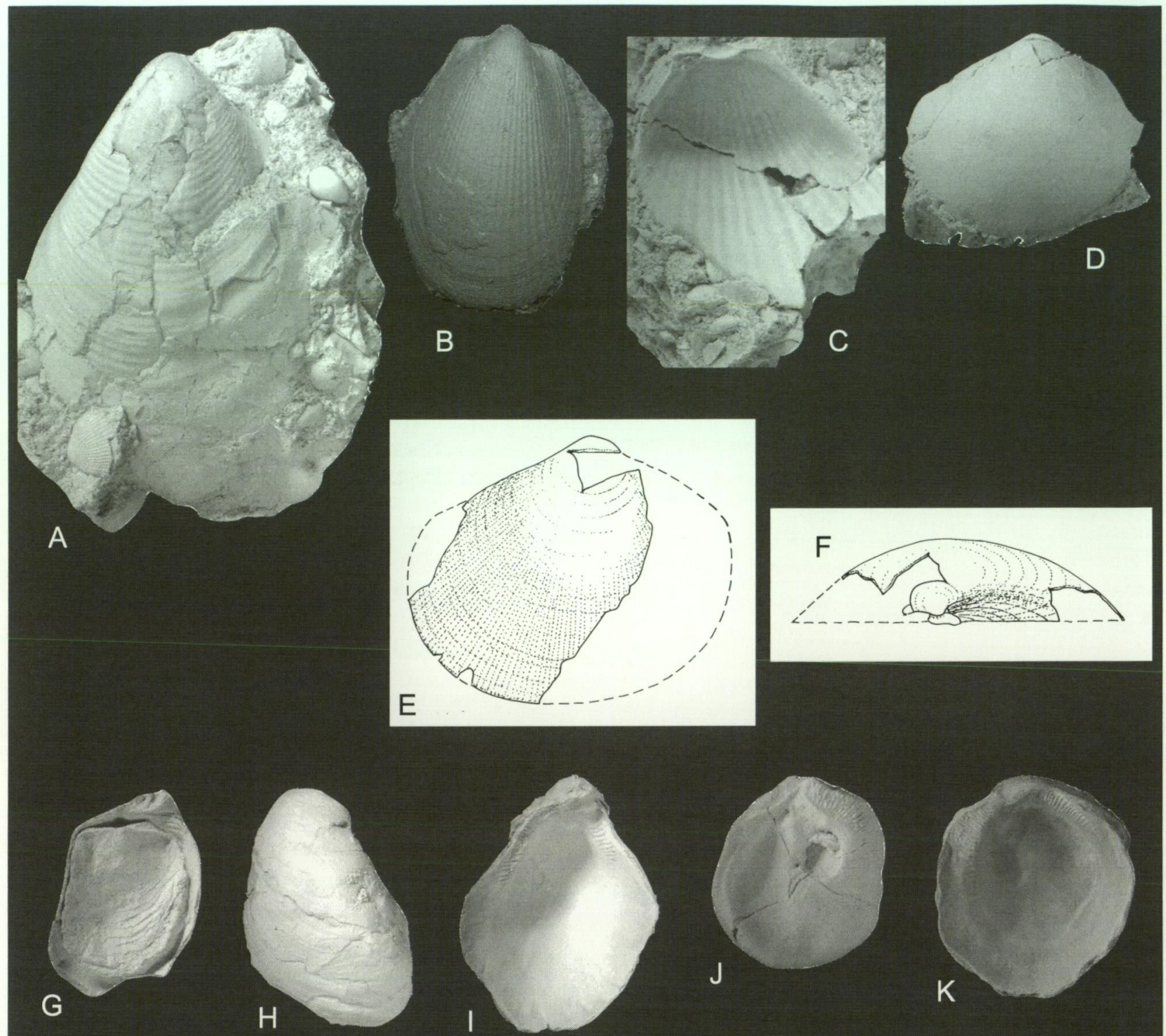

L
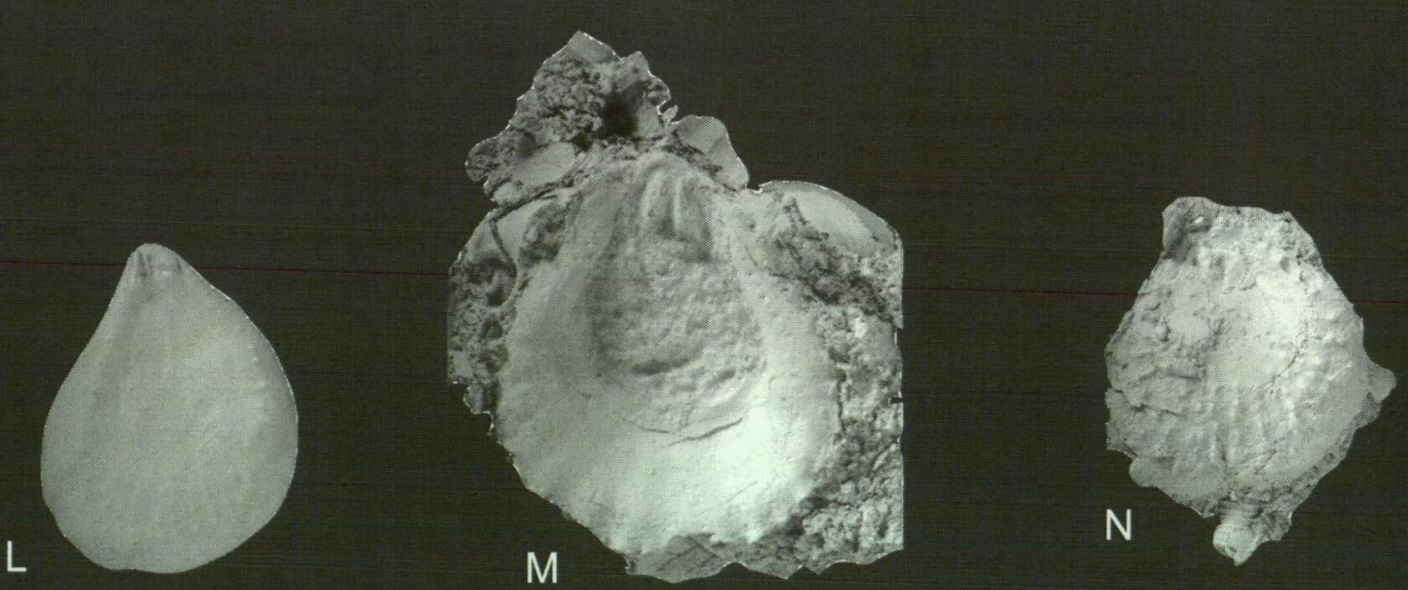

Figure 8 Inoceramus pictus J. Sowerby. A ARI G2887, LV external x 1. Limatula persimilis (Stoliczka). B ARI G2695/4, LV external x 7.5. Limatula sp. C ARI G2833, LV internal x 2. Plagiostoma ootatoorensis (Stoliczka). D ARI G2925, juvenile LV external x 3. E, F ARI G2925, juvenile LV external and dorsal aspects, drawings $x 4$. Pycnodonte vesiculosa (J. Sowerby). G WAM 98.217c, conjoined pair (RV) x 1. H WAM 98.217b, LV external x 1. I WAM 98.217a, LV internal x 1. J WAM 98.216i, RV internal x 1. K WAM 98.217d, LV internal x 1.5. Plicatula (Darteplicatula) sessilis) Stoliczka. L ARI G2837/1, LV internal x 1. M ARI G2902, RV internal x 1.5. N ARI G2837/4, RV external x 1. 


\section{Genus Plagiostoma J. Sowerby, 1814}

\section{Type species}

Plagiostoma giganteum J. Sowerby, 1814, by subsequent designation of Stoliczka 1871. Jurassic, England.

\section{Plagiostoma ootatoorensis (Stoliczka, 1871)} Figure $8 \mathrm{D}-\mathrm{F}$

1871 Radula (Plagiostoma) ootatoorensis Stoliczka: 417, pl. 29, fig. 3, 3a.

1987 Plagiostoma ootatoorensis (Stoliczka); Tapaswi: 509. List only.

\section{Material examined}

\section{Lectotype}

Here designated, GSI Stoliczka Collection 1281, conjoined valves in pale-brown earthy limestone, from east of Uttattur village, Uttattur Group.

\section{Other material}

ARI G2925, LV, Locality 3.

\section{Diagnosis}

Deferred (see Remarks).

\section{Description}

Medium sized, thin-shelled, obliquely ovate, length exceeding height, slightly extended anteriorly; inflated, maximum inflation centred in postero-dorsal quadrant; umbones opisthogyrate, slightly elevated; lunule large, deeply excavate, with carinate border occupying most of dorsal margin; antero-dorsal margin almost straight, longer than slightly convex postero-dorsal margin; other margins well rounded (posterior margin missing); sculpture of faint, thin, well spaced growth striae, more evident on juvenile shell where they number 12 in height of $8 \mathrm{~mm}$; stepped growth ridges cross otherwise smooth median area; flanks with fine, low, radial costellae (mature shell) with incised, linear interspaces, obsolete medially; lunular surface ridged commarginally and with a few weak radial costellae. Margin smooth, other internal characters unknown.

Dimensions of Plagiostoma ootatoorensis (Stoliczka).

\begin{tabular}{lccc}
\hline Specimens & Length & Height & Inflation \\
\hline $\begin{array}{l}\text { GSI 1281, conjoined valves, } \\
\text { lectotype }\end{array}$ & 95 & $72^{*}$ & 41.5 \\
ARI G2925, LV & 11.9 (est.) & 9.82 & 4.5 \\
\hline
\end{tabular}

* ventral margin lacking several mm

\section{Remarks}

The species was erected for a single, incomplete, probably mature, conjoined pair, which was examined (G.W.K.) in February 1998. The LV was found to be badly crushed and deformed by compaction; the umbo, most of the dorsal margin and parts of the lunular and median-ventral areas lack shell. RV retains shell only on the ventral third with fragments on the centre of the disc and posterior extremity. Stoliczka's figure appears to be an idealised depiction of the species and not an accurate representation of the specimen, at least in its present condition. The only other known specimen of Plagiostoma ootatoorensis, ARI G2925, is an incomplete juvenile LV, which, so far as can be determined, agrees reasonably well with the lectotype. No full redescription and diagnosis of this poorly known species is possible from the material presently to hand.

The relationship of Plagiostoma to the genus Acesta H. and A. Adams has been discussed by Hayami (1965a: 327) and by Stilwell and McKenzie (1999). On the available external characters, the present species seems better located in the former.

\section{Occurrence}

Uttattur Group. Pale brown earthy limestone east of Uttattur (type); Odiyam Locality 3. Karai Formation (Kunnam Member). Cenomanian. Rare.

\section{Order Ostreoida Férussac, 1822}

Superfamily Ostreoidea Rafinesque, 1815

Family Gryphaeidae Vyalov, 1936

\section{Subfamily Pycnodonteinae Stenzel, 1959}

Genus Pycnodonte Fischer de Waldheim, 1835

\section{Type species}

Pycnodonte radialis Fischer de Waldheim, 1835, by original designation. Late Cretaceous, Crimea.

\section{Pycnodonte vesiculosa (J. Sowerby, 1823) Figure $8 \mathrm{G}-\mathrm{K}$}

1823 Gryphaea vesiculosa Sowerby, 4: 93, pl. 369.

1871 Gryphaea vesiculosa Sowerby; Stoliczka: 466, pl. 39, figs 1,2 .

1912 Pycnodonta vesiculosa (Sowerby); Pervinquière: 195.

1913 Ostrea vesiculosa (Sowerby); Woods: 374, 375, pl. 55, figs 10-14; pl. 56, fig. 1. Synonymy.

1939 Ostrea vesicularis Lamarck (forme hippopodium); Marlière: 99, pl. 6, fig. 4a, 4b.

1979 Pycnodonte (Phygraea) vesiculosa Sow; Chiplonkar and Tapaswi: 140, 145, 161, 163. 
1987 Pycnodonte (Phygraea) vesiculosa (Sowerby); Tapaswi: 509. List only.

\section{Material examined}

India: GSI Stoliczka Collection 1400, LV from Pudur; 1401, LV from Odiyam. ARI G2696, four LVs, Locality 1; G2770, three LVs, one RV, Locality 2; G2900, 12 LVs, one RV, Locality 3. Also WAM 88.483 , six LVs, seven conjoined pairs from Sattanur; 98.216, seven LVs, one RV, one conjoined pair; 98.217, $39 \mathrm{LVs}, 15 \mathrm{RVs}$, four conjoined pairs, all from "badlands" E of Karai village. Total of 103 specimens.

\section{Diagnosis}

Small Pycnodonte, length to $36 \mathrm{~mm}$, usually of strongly inflated, sub-grypheate form; posterior area weakly or not differentiated. Apparently ancestral to and sometimes synonymised with $P$. vesiculare (Lamarck). Distinguished from latter by its "smaller size, thinner shell, more tumid and very indistinctly or not at all lobed larger valve, and the almost smooth pallial impression, etc." (Stoliczka 1871: 466).

\section{Description}

Study material (Odiyam) comprises small (juvenile and immature) specimens, all single valves and all variously embedded in hard sediment. Shell of variable, sub-gryphaeate form; proportions of (attached) LV influenced by nature of attachment object; small attachment object generates LV with narrow, incurved, strongly inflated umbones; larger attachment objects lead to more compressed LV with lower, wider umbo; umbo usually prosogyrate and, unless truncated, apically incurved; posterior area (LV), where present, weakly defined, sub-alate and with weak sulcus; anterior area, if present, weak or obscure; vesicular microstructure present within attachment area; weak clasping processes occasionally present; interior not visible; sculpture of LV comprises fine, close, commarginal growth lamellae; RV more or less flattened or externally concave and with strongly reflexed commissural shelf, fitting against that of LV; sculpture (RV) of fine commarginal growth lamellae, crossed by few short, spaced, radial gashes, seen on mould.

Pycnodonte vesiculosa is common and well preserved on "bad land" terrain along the western margin of the Karai Formation south of Varaguppadi quarry and east of Karai village. A series of 67 specimens from there (WAM 98.216, 98.217) has small attachment areas (LV); ligamental areas small, shallow and variably aligned; chomata well developed around dorsal margins of body cavity of both valves, anterior set simple, posterior may be branched; adductor scars subcircular to subreniform, centred in postero-dorsal quadrant, myostracum often dissolved.
Dimensions of Pycnodonte vesiculosa (J. Sowerby).

\begin{tabular}{lccc}
\hline Specimens & Length & Height & Inflation \\
\hline $\begin{array}{l}\text { GSI Stoliczka Collection } \\
\quad 35.6\end{array}$ & 38.2 & 19 \\
$\quad$ 1400, LV & & & \\
GSI Stoliczka Collection & 18.6 & 19.0 & 10 \\
$\quad$ 1401, LV & 21 & 18 & 14 \\
ARI G2770/1, LV & 21 & 20 & 7 \\
ARI G2770/2, RV & 27 & 27 & 6 \\
WAM 98.216i, RV & 28 & 37 & 15 \\
WAM 98.217a, LV & &
\end{tabular}

All of the above specimens are abraded around the margins

\section{Remarks}

This wide-ranging species (or subspecies of Pycnodonte vesiculare (Lamarck)) is characteristic of Aptian to Cenomanian assemblages in Western and Central Europe, N Africa, the Levant and India (Stoliczka 1871, Pervinquière 1912, Woods 1913, Marlière 1939, Mongin 1979). Occasional specimens of this form occur, possibly as part of a morphocline, within post-Cenomanian populations of $P$. vesiculare as late as the Senonian (Marlière 1939: 99) and Santonian (Feldtman 1963, Darragh and Kendrick 1991: 36).

Ayyasami and Jagannatha Rao (1979) recorded Pycnodonte vesiculosa associated with Calycoceras newboldi Kossmat from near Kallakkudi in sediments (probably Karai Formation) re-assigned to the Uttattur Group, earlier located by Blanford (1862) in the "Trichinopoly Group". The nature of the $P$. vesiculosa $-P$. vesiculare lineage in the Cauvery Basin merits further study. The latter species is common in the calcarenites of the Ariyalur Group (Fürsich and Pandey 1999). Nine specimens of $P$. vesiculosa (WAM 88.483) from "Earthy clays and shell limestone, Sattanur, Uttattur Group and Trichinopoly Group", are probably from both Karai and Kulakkalnattam Formations.

Apparent gastropod predation is shown on nine specimens (eight LVs, one RV) out of 103 specimens $(8.7 \%)$ of Pycnodonte vesiculosa (WAM 98.216, 98.217) from the "bad lands" of the Karai Formation ca $1 \mathrm{~km}$ south of Varaguppadi quarry and $2 \mathrm{~km}$ east of Karai village; these are probably of Late Albian age. Three specimens have been bored twice; of a total of 12 boreholes in this sample, only two have penetrated entirely through the shell. Most of these bore holes are of cylindrical form (diameter 1.7-1.8 $\mathrm{mm}$ ), consistent with predation by the epifaunal neogastropod family Muricidae.

\section{Occurrence (India)}

Uttattur Group. "East of Poodoor and NE of Odium in a whitish friable calcareous rock" (Stoliczka 1871). Karai Formation. Cenomanian. Near Kallakkudi (Ayyasami and Jagannatha Rao 1979). Karai Formation. Cenomanian. Odiyam 
Localities 1, 2 and 3. Karai Formation (Odiyam and Kunnam Members). Cenomanian. South of Varaguppadi quarry, E of Karai village. Karai Formation. Albian? Sattanur, "earthy clays and shell limestone". Probably mixed Karai and Kulakkalnattam Formations (latter Trichinopoly Group). Albian?, Cenomanian-Turonian?.

\section{Superfamily Plicatuloidea Watson, 1930}

\section{Family Plicatulidae Watson, 1930}

\section{Remarks}

The systematic positions of the Plicatulidae and Dimyidae have been examined by Yonge (1975, 1980 ) and in a wider review of the Pteriomorpha by Waller (1978). We follow the latter in recognising superfamilial status for the monomyarian Plicatuloidea, separate from the Dimyoidea.

\section{Genus Plicatula Lamarck, 1801}

\section{Type species}

Spondylus plicatus Linnaeus, 1758 , by subsequent designation of Schmidt 1818. Recent, Indo-Pacific.

\section{Subgenus Darteplicatula Freneix and Gorodiski, 1963}

Trichiplicatula Chiplonkar and Tapaswi, 1975.

\section{Type species}

Plicatula polymorpha Bellardi, 1854. Eocene, Nigeria.

\section{Remarks}

Chiplonkar and Tapaswi (1975c) erected Trichiplicatula, as a subgenus of Plicatula, for the species $P$. (T.) distincta Chiplonkar and Tapaswi from "Buff coloured calcareous sandstone from Trichinopoly group at about $2 \mathrm{~km} \mathrm{NE}$ of Saradamangalam", probably Sillakudi Formation (Santonian-Campanian). The original subgeneric diagnosis is, "Small to medium-sized, higher than long; auricles more or less distinct and may be ornamented; adductor muscle mark subcentral; interior with tubercles along the margin; external ornament of radial ribs (may be spinose)".

Trichiplicatula was differentiated from Plicatula s. str. by "its subcentral muscle mark, better developed auricles, and internally a row of tubercles all along the margin". From Darteplicatula, Trichiplicatula was said to differ "in having its shell higher than long, with more regular and suboval outline, RV more convex and the subcentral position of the adductor muscle mark (which is quite posteriorly placed in Darteplicatula), tubercles along the internal margin distinctly rounded (not costate) and absence of submicroscopic radial striations" (Chiplonkar and Tapaswi 1975c).

The holotype and only known specimen of Plicatula (Trichiplicatula) distincta Chiplonkar and Tapaswi (ARI Sd 228/70) is a small LV (not RV as stated) measuring L 18.42, Ht 22.08, Infl. $6.38 \mathrm{~mm}$; figures are enlarged $\times 1.6$. The reniform adductor scar is centred in the postero-dorsal quadrant; there is no attachment area. The first $18 \mathrm{~mm}$ of growth are occupied by the xenomorph of an inflated, commarginally ribbed bivalve, beyond which the normal plicatulid radials (ca 18) with erect scales develop. A small posterior auricle is present but this part of the margin is deformed to some extent by the xenomorph. Body cavity is bordered by a row of fine, irregularly spaced tubercles, lacking associated radial striation. $\mathrm{RV}$ of the species is unknown.

Recognition of the holotype of $P$. (T.) distincta Chiplonkar and Tapaswi as a xenomorph-deformed LV leads us to conclude that (a) the species concept requires clarification from further topotypic material and (b) Trichiplicatula Chiplonkar and Tapaswi, 1975 is not significantly different from Darteplicatula Freneix and Gorodiski, 1963, under which it is here synonymised.

\section{Plicatula (Darteplicatula) sessilis Stoliczka, 1871} Figure $8 \mathrm{~L}-\mathrm{N}$

1871 Plicatula sessilis Stoliczka: 446, 447, pl. 34, fig. 21; pl. 47, figs 5-7.

1987 Plicatula (Plicatula) sessilis Stoliczka; Tapaswi: 508. List only.

\section{Material examined}

\section{Lectotype}

Here designated. GSI Stoliczka Collection 1457, RV in brown sandy limestone from "Ootatoor Ootatoor Group".

\section{Paralectotypes}

GSI Stoliczka Collection 1456, 1458. RV and conjoined pair respectively, in brown sandy limestone, from type locality.

\section{Other material}

ARI G2837, six LVs (interiors, one mostly decorticated), one RV (exterior), Odiyam Locality 2; G2902, one RV (interior). Locality 3. Total of eight single valves.

\section{Diagnosis}

Medium sized (height up to $44 \mathrm{~mm}$ ), compressed Darteplicatula, higher than long, RV larger than LV, with small attachment area and 13-20 narrow, 
spaced, nodose to subspinose, radial-divaricate costae; auricles (RV) small; $\mathrm{LV}$ with internal row of spaced tubercles and fine radial ridges; $R V$ correspondingly punctate.

\section{Description}

Medium-sized for genus and subgenus, robust, compressed, higher than long, triangularly subovate, attenuated dorsally, maximum length in ventral half; slightly produced posteriorly; RV larger than LV, slightly to moderately convex, with small attachment area; LV flat to slightly concave, reflexed ventrally; anterior margin short, convexly rounded; postero-dorsal margin extended, slightly concave, the two convergent on short dorsal margin; auricles (RV) small, absent or abraded on $\mathrm{LV}$; ventral margin broadly rounded; sculpture probably discrepant, RV with 13-20 low, narrow, spaced, nodose to subspinose, radial-divaricate costae and weak growth ridges; LV sculpture radially costate, poorly indicated on study material; $\mathrm{LV}$ adductor scar ovate-pyriform, centred in postero-dorsal quadrant; LV body cavity bordered by row of small tubercles, with or without additional radially aligned tubercles; body cavity of $\mathrm{RV}$ with corresponding row of fine punctae; ventral margins weakly internally crenulate, each with thin peripheral flange (commonly abraded) of darker colour than interior; auricles (RV) small, if originally present on LV, abraded; resilium (LV) deep, wide, bordered by two inner and two stronger, outer erect, slightly divergent cardinal crura, striate on outer edges; RV resilium narrower than that of LV, bordered by two strong, centrally placed, divergent crura.

On all specimens, the peripheral flange appears to have undergone abrasion, probably reducing the dimensions.

Dimensions of Plicatula (Darteplicatula) sessilis Stoliczka.

\begin{tabular}{lccc}
\hline Specimens & Length & Height & Inflation \\
\hline GSI 1457, RV, lectotype & 33.8 & 39.3 & ca 6.6 \\
GSI 1456, RV, paralectotype & 21 & 24 & ca 6 \\
GSI 1458, pair, & & & \\
$\quad$ paralectotype (RV) & 43 & 44 & 14.6 \\
GSI 1458, pair, & & & \\
$\quad$ paralectotype (LV) & ca 29 & 34 & - \\
ARI G2837/1, LV & 26.41 & 33.64 & 3 (est.) \\
ARI G2837/2, LV & 25.42 & 28.58 & 3 (est.) \\
ARI G2837/4, LV & 28 (est.) & 30.5 (est.) & 4 (est.) \\
ARI G2837/5, LV & 37 (est.) & 40 (est.) & - \\
ARI G2837/7, LV & 24.10 & 30.72 & - \\
ARI G2902, RV & 23.1 & 27.68 & - \\
\hline
\end{tabular}

\section{Remarks}

The extant type material of the present species presents mostly external characters; internal characters are detailed herein for the first time. The lectotype, according to its label, that figured on
Stoliczka's pl. 47, fig. 6, is an RV with ca 13 low, spaced, weakly nodose radial costae and a small attachment area $(9 \times 8 \mathrm{~mm})$; the postero-ventral area is missing. The caption for Stoliczka's pl. 47, fig. 6 gives the locality "near Mooraviatoor". Paralectotype 1456 (figured pl. 47, fig. 5) is an RV internal mould with shell remnants indicating ca 15 radial costae and a small attachment area; no adductor scar discernible. Paralectotype 1458 (pl. 47 , fig. 7,7 a) comprises poorly preserved paired valves, devoid of outer surfaces and cardinal areas. Stoliczka's localities were "Ootatoor, Odium and Mooraviator, in yellowish brown or dark brown earthy limestone; not common". Specimens from the two latter localities were not located in the GSI Stoliczka Collection, Kolkata, in February 1998. All of Stoliczka's figured specimens were RVs.

Stoliczka (1871) compared the present species with "Plicatula spinosa Mant.", presumably $P$. spinosa J. Sowerby from the Lower and Middle Lias. The RV sculpture of these species is not dissimilar but Sowerby's species appears not to attain the size of the other and lacks its internal tubercles/punctae. $P$. (D.) sessilis is more finely sculptured and smaller than $P$. gurgitis Pictet and Roux from the Gault (Albian); its sculpture is much weaker and more spaced than that of $P$. multicostata Forbes, from "Verdachellum" (Ariyalur Group, Maastrichtian). P. sessilis shows "Upper Greensand affinities", according to Chiplonkar and Tapaswi (1979: 138). This appears to be the first record of the subgenus from the Cretaceous, the stratigraphic range now being extended to Albian - Lower Miocene (Cox and Hertlein 1969). An origin for the subgenus in the Southern Temperate Realm seems possible.

Valve orientation and attachment in Plicatula have been discussed by Kanji Lal (1996), who notes the incorrect valve designations for $P$. marginata Say in Cox and Hertlein (1969: N377, N378, fig. C98, $1 \mathrm{a}-\mathrm{d})$.

\section{Occurrence}

Uttattur Group. "Ootatoor [type], Odium and Mooraviatoor, in yellowish brown or dark brown earthy limestone; not common" (Stoliczka 1871). Of Stoliczka's three localities, the first two are assigned to the Karai Formation, the first-mentioned perhaps from the older, Albian part. His third locality, Muravattur, probably derives from a limestone unit of the Albian Dalmiapuram Formation. Odiyam Localities 2 and 3. Karai Formation (Odiyam and Kunnam Members). Cenomanian. Uncommon.

\section{Superfamily Dimyoidea P. Fischer, 1886 [Pilsbry} 1922]

$$
\text { Family Dimyidae P. Fischer, } 1886
$$




\section{Remarks}

The systematic position of the Dimyidae follows Waller (1978) and Hodges (1991).

\section{Genus Atreta Étallon, 1862}

Diploschiza Conrad, 1866

Cyclostreon Eichwald, 1868

Dimyodon Munier-Chalmas in Fischer, 1886

Dimyopsis Bittner, 1895

\section{Type species}

Ostrea blandina d'Orbigny, 1850, by subsequent designation of Cox 1964. Oxfordian, France.

\section{Atreta redunca sp. nov.}

Figure $9 \mathrm{~A}-\mathrm{G}$. Figure $10 \mathrm{~A}-\mathrm{F}$

\section{Material examined}

\section{Holotype}

ARI G2771/1, LV, from brown calcareous siltstone with abundant turritellid gastropods, beside track ca $0.5 \mathrm{~km}$ west of Odiyam village, Perambalur Taluk, Tiruchirapalli district, Tamil Nadu (Locality 2).

\section{Paratypes}

ARI G2771/2-13, nine LVs, three RVs, from type locality; G2697, eight LVs, three RVs, Locality 1; G2901/1, RV, Locality 3. Total of 25 single valves (18 LVs, seven RVs).

\section{Other material}

ARI G2771, eight LVs, seven RVs from Locality 2; G2901, two LVs, Locality 3. Total of 10 LVs and seven RVs (plus type material).

\section{Diagnosis}

Small, length to $10 \mathrm{~mm}$, irregularly subcircular; crura short, striate, on RV more prominent and more divergent (ca 90\%); anterior adductor scars impressed, ovate, near edge of body cavity; posterior adductor scars much larger, lightly impressed, of variable outline but essentially unilobate, not near edge of body cavity; attachment area (RV) small; RV sculpture of weak to strong radial costellae; LV sculpture unknown.

\section{Description}

Material comprises single valves, of which only two present external surfaces. Valves small, thin, robust, oyster-like, irregularly and often obliquely subcircular; usually extended posteriorly; valves discrepant in most characters, RV usually more excavate, each with broad, sub-nacreous, commissural flange, that of LV reflexed and lying within extended margin of RV; dorsal margin short and usually non-auriculate; beaks acuminate, small, slightly projecting; resilium extending to margin, triangular, broader in RV; cardinal crura short, striate, divergent, on $\mathrm{RV}$ raised and subtending angle of ca $90^{\circ}$; on LV, crura much lower, divaricate and usually subtending acute angle; crura (both valves) near apex of distinct rim offsetting body cavity from marginal flange, rim bordered along outer edge by continuous row of fine, close, radial crenulae; surfaces of body cavity and flange of contrasting colours and lustre, latter darker and sub-nacreous; musculature dimyarian, anisomyarian; LV anterior adductor scar small, ovate to elliptical, well impressed, with rounded extremities, higher than long and close to rim of body cavity; not greatly variable; posterior adductor scar of LV much larger, lightly impressed, of irregular and variable outline but essentially unilobate, more distant from rim than anterior scar; RV anterior adductor scar small, recessed, subcircular to subovate, located close to rim and to end of anterior crus; RV posterior adductor scar similar to that of LV; on well preserved specimens, faint, commarginal, micro-ridges are visible crossing posterior adductor scars; pallial line faint, well within body cavity; RV has small attachment area, succeeded by radially sculptured exterior bearing ca 10 short, low costellae, which do not extend onto marginal flange; whole exterior (RV) bears very fine, commarginal micro-lamellae; LV sculpture unknown; valves lacking inner aragonitic layer show fine, irregular, bifurcating, radial costellae (45-60+), which appear to merge with row of crenulae around rim of body cavity.

Dimensions of Atreta redunca sp. nov.

\begin{tabular}{lccc}
\hline Specimens & Length & Height & Inflation \\
\hline ARI G2771/1, LV, holotype & 7.74 & 8.74 & 1.5 (est.) \\
ARI G2771/2, LV, paratype & 8.18 & 7.79 & 1.3 (est.) \\
ARI G2771/6, RV, paratype & 9.08 & $-^{*}$ & 2.43 \\
ARI G2771/10, LV, paratype & 10.22 & 8.79 & 1.9 (est.) \\
ARI G2771/11, LV, paratype & 9.10 & 10 (est.) & 0.9 (est.) \\
ARI G2771/12, RV, paratype & 9.72 & 9.34 & 2.4 (est.) \\
ARI G2771/13, RV, paratype & 8.35 & 8.31 & 1.78 \\
\hline
\end{tabular}

* dorsal extremity missing

Because of abrasion around the margins, all of the above length and height data probably understate the original dimensions

\section{Remarks}

All available characters, including unambiguous dimyarian musculature, locate the species within the Dimyidae, concerning which family recent studies (e.g. Fürsich and Werner 1988, Malchus 2000, Hautmann 2001) have concurred in assigning Mesozoic taxa to the genus Atreta Étallon.

Among Cretaceous dimyids, the study material is 

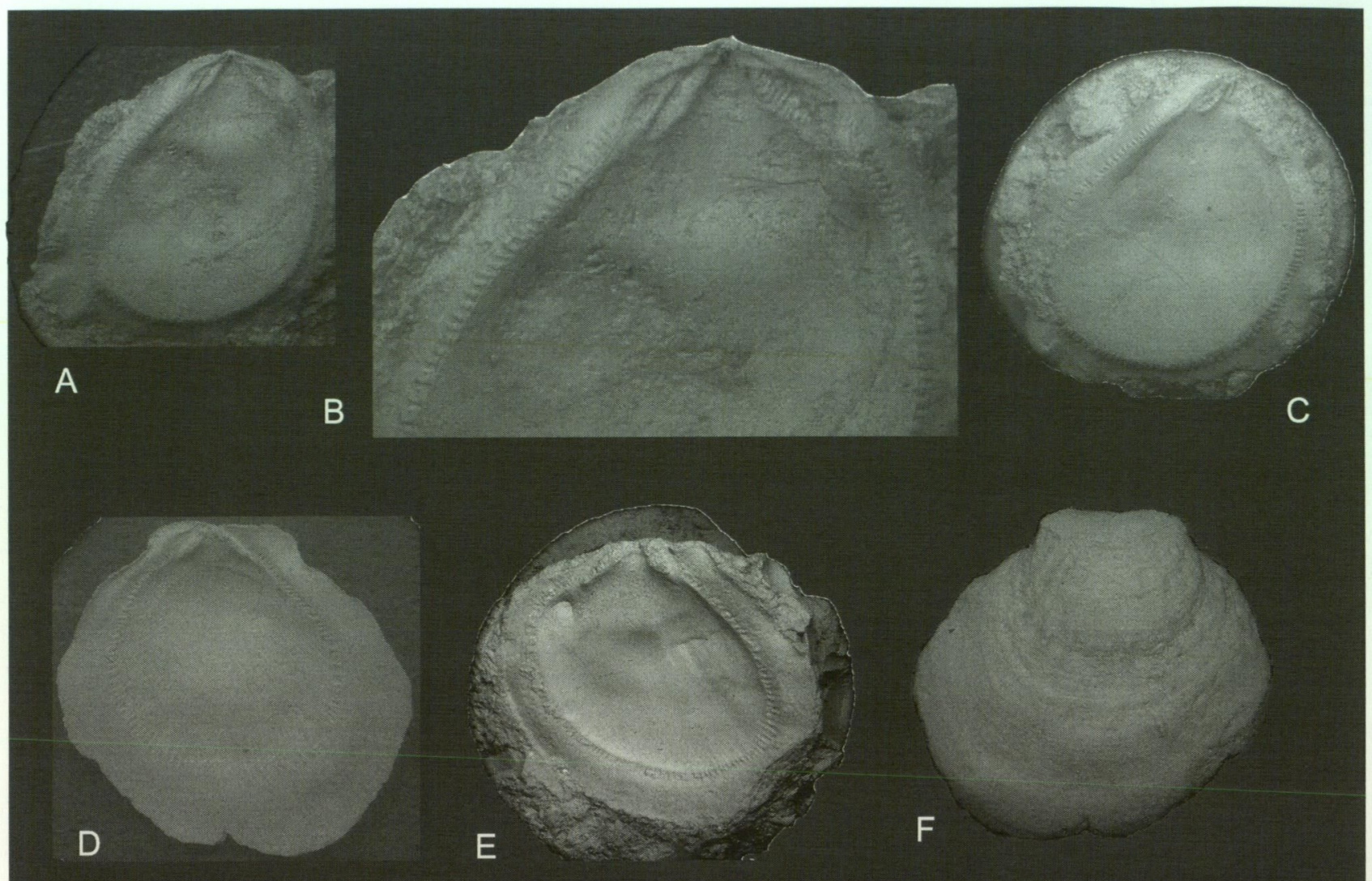

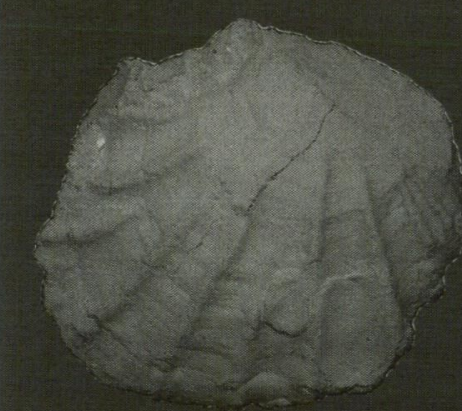

G
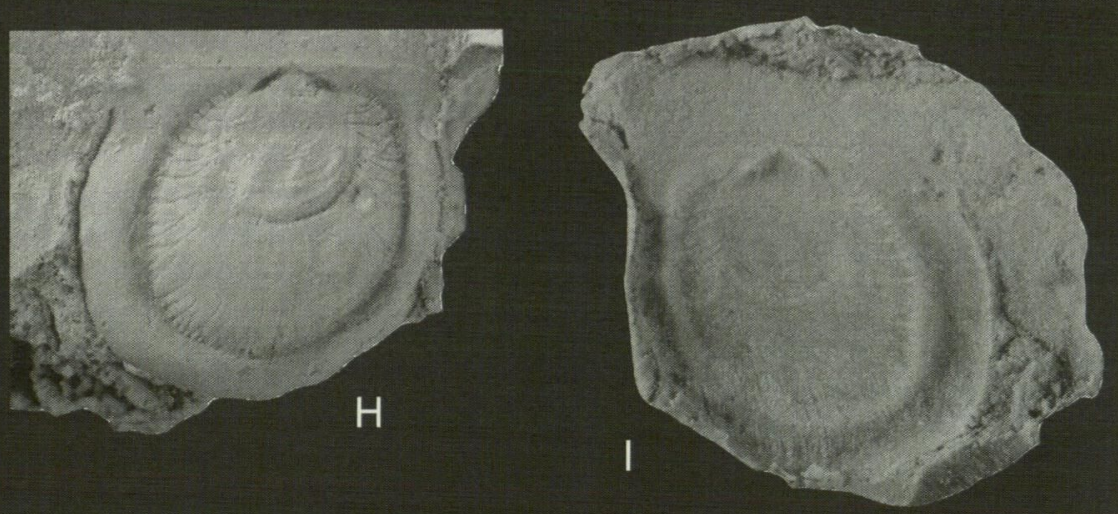

Figure 9 Atreta redunca sp. nov. A, B ARI G2771/1, holotype, LV internal x 5 and hinge area x 10. C ARI G2771/11, paratype, LV internal x 5. D ARI G2901/1, paratype, RV internal x 5.5. E ARI G2771/5, paratype, RV internal x 5.5. F ARI G2901/1, paratype, RV external x 5.3. G ARI G2771/13, paratype, RV external x 5.0. Atreta sp. H ARI G2903, natural mould, LV internal x 5.0. I ARI G2903, latex cast from natural mould, LV internal x 5.0.

notable for the frequently good preservation of both cardinal features and adductor scars and also in the predominance of upper LVs over attached RVs. Attachment areas appear to have been small; paratype G2771/13 (RV) retains attachment to an indeterminable shell fragment. Most specimens and all of the LVs present interiors only, a consequence of hard sediment adhesion to the outer surfaces; two RVs only show both surfaces. Hodges (1991) reported a bilobed posterior adductor scar on specimens of Atreta intusstriata (Emmrich) from the
Rhaetian of Austria but this has not been observed on our material. The present species differs from $A$. nilssoni (Hagenow), from the Albian to Danian of Europe (see Grönwall 1906: 205), in its more acutely inclined dorsal margins and small area of attachment (RV). From Atreta sp. (this paper), it differs in its non-auriculate dorsal margin and weaker, less divergent crura.

Among Mesozoic dimyids in particular, diagenetic dissolution of the thin inner subnacreous (aragonitic) shell layer often results in loss of the 
cardinal area, myostracum and most of the peripheral flange (Cox 1964). Indian examples are the "Diploschiza" species from the Uttattur Group (presumably Karai Formation) near Kunnam and Odiyam villages reported by Rao (1964), which may be conspecific with the present species. Another poorly preserved species, Atreta glauerti (Feldtmann), common in the Santonian chalks of the Perth and Carnarvon Basins of Western Australia (Feldtmann 1963, McNamara et al. 1993), recalls the study material, differing from it in its finer, more numerous RV radials. Hinge and musculature are unknown for Feldtmann's species. An undetermined species of Atreta was reported from the Maastrichtian Miria Formation of the Carnarvon Basin, Western Australia by Darragh and Kendrick (1991). The species was compared with the European A. nilssoni (Hagenow) but characters of the hinge and musculature remain unknown.

Soares and da Silva (1970) described Atreta nevesi from the Santonian-Campanian Mandejene Formation of southern Mozambique and cited other African records for the genus from the Albian of Somalia (Tavani 1942) and Maastrichtian of Madagascar (Collingnon 1949). Stilwell (1998) recorded a dimyid (as Dimyodon n. sp.) from the Campanian?-Maastrichtian Kahuitara Tuff of Pitt Island, Chatham Islands, South Pacific. Apparent differences from the present species include a less inflated $R V$, more inflated $L V$ and reduced $R V$ sculpture; adductor scars were poorly preserved.
Should this material, on re-evaluation, prove to be referrable to Atreta, it would indicate a substantial extension of geographic range for the genus, which may prove to have been near-cosmopolitan for much of the Cretaceous. Malchus (2000) described early shell growth in a species of Atreta from the Middle Jurassic (Callovian) of Poland, which, from features of the prodissoconch, suggested a planktotrophic larval stage. These are not discernible on the present material.

\section{Etymology}

Latin redunca (fem.), bent or curved backwards, from the reflexed commissural flange of the $\mathrm{LV}$.

\section{Occurrence}

Uttattur Group. Odiyam Localities 1, 2 and 3. Karai Formation (Odiyam and Kunnam Members). Cenomanian.

\section{Atreta sp. \\ Figure $9 \mathrm{H}, \mathrm{I}$}

\section{Material examined}

ARI G2903, internal mould of LV, Locality 3.

\section{Description}

Small, compressed, obliquely subovate, slightly produced posteriorly, about as high as long; dorsal margin straight, extended, biauriculate; beak
A

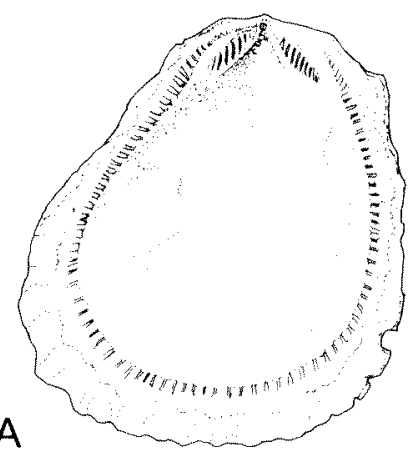

B

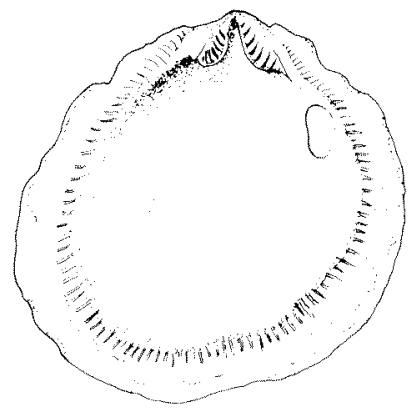

C
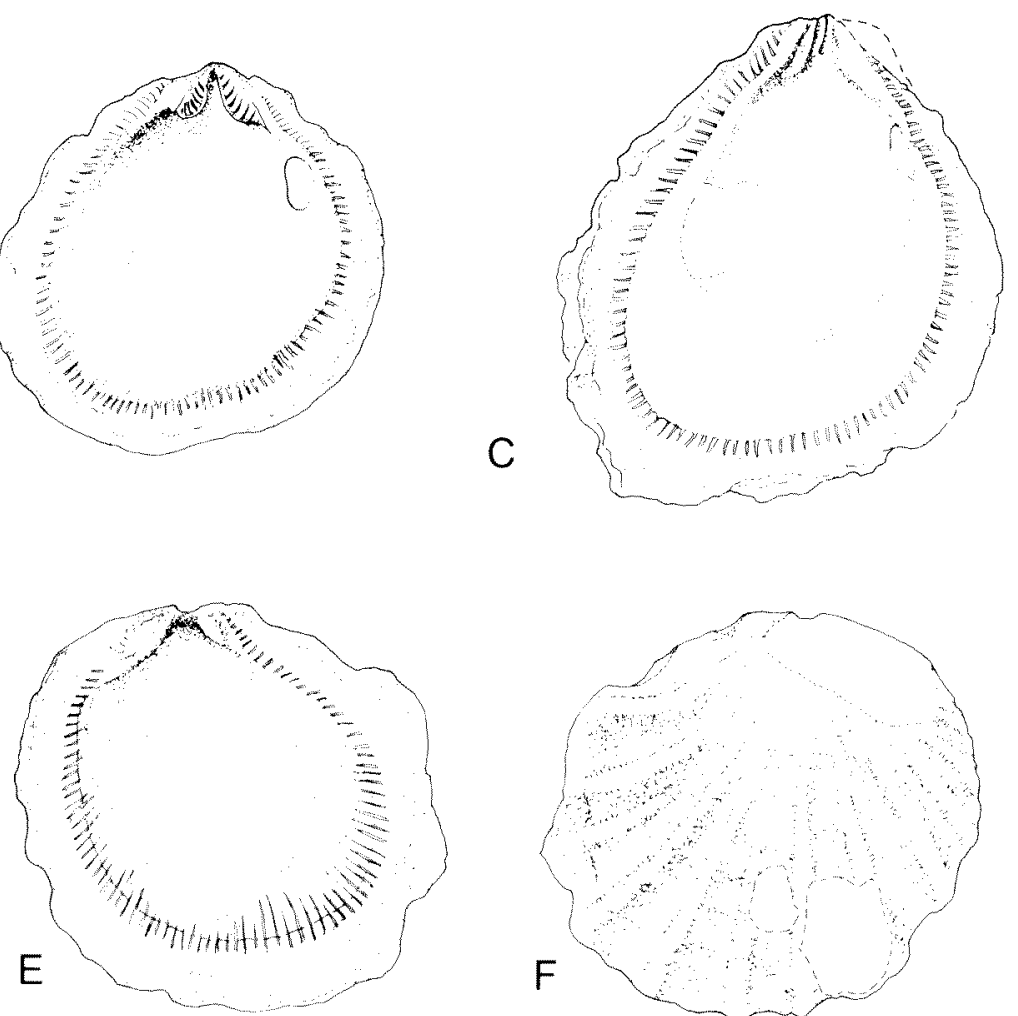

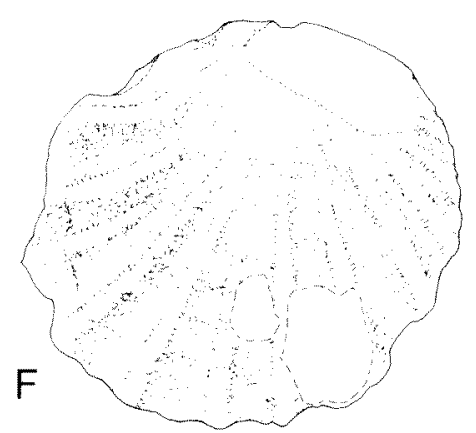

Figure 10 Atreta redunca sp. nov. A ARI G2771/1, holotype, LV internal x 5. B ARI G2771/2, paratype, LV internal x 5. C ARI G2771/11, paratype, LV internal x 5. D ARI G2771/5, paratype, RV internal x 5. E ARI G2771/13, paratype, RV internal x 5. F ARI G2771/13, paratype, RV external x 5 . 
central, minute; other margins more or less evenly rounded; adductor scars faintly indicated, posterior larger and shallower, both located well within body cavity; crura small, thin, without discernible crenulation, obtusely divergent about broad, shallow resilium at apical conjunction of prominent commarginal ridge bordering shallow body cavity; thin, spaced, bifurcating, radial costellae cross body cavity, intensifying on ridge; previous commarginal ridge retained on mould as shallow groove; broad reflexed commissural shelf borders all margins except dorsal.

Dimensions of Atreta sp.

\begin{tabular}{cccc}
\hline Specimen & Length & Height & Inflation \\
\hline ARI G2903 & 9.5 & 9.5 & - \\
\hline
\end{tabular}

\section{Remarks}

The specimen is separated from the foregoing species by its biauriculate dorsal margin, adductor scars being faintly impressed and located well within the body cavity and the stronger, obtusely divergent, non-crenulate crura, inter alia. The original LV specimen appears to have lost much of its internal, aragonitic surface, resulting in some loss of detail on the mould and enhancement of the radial costellae of the calcitic outer layer. The specimen is not unlike the long-ranging and widely distributed Atreta nilssoni (Hagenow) but the limitations of the available material preclude a more positive determination.

\section{Occurrence}

Uttattur Group. Odiyam Locality 3. Karai Formation (Kunnam Member). Cenomanian. Rare.

\section{Superfamily Pectinoidea Wilkes, 1810}

\section{Family Entoliidae von Teppner, 1922 \\ Genus Syncyclonema Meek, 1864}

\section{Type species}

Pecten rigida Hall and Meek, 1865 non Sowerby, 1818 =Pecten halli Gabb, 1861. Upper CampanianMaastrichtian, N America. By original designation.

\section{Remarks}

In the familial location of Syncyclonema, we follow Waller (1984: 219).

\section{Syncyclonema? sp. Figure $11 \mathrm{~A}-\mathrm{G}$}

\section{Material examined}

ARI G2698, 15 single valves, Locality 1; G2775, seven RVs and one valve of uncertain orientation,
Locality 2; G2889, seven LVs, eight RVs, Locality 3. Total of 38 fragmentary single valves.

\section{Description}

Shell small, height to $16 \mathrm{~mm}$, thin, subvitreous, compressed, higher than long; beaks acute, projecting slightly above auricular margin; umbones slightly inflated, acline, margins gently convex and subtending angle of $80^{\circ}-85^{\circ}$; umbonal margins sharply defined against auricles on RV, less so on LV. Sculpture of both valves apparently similar; unabraded specimens show first 3.0-3.5 $\mathrm{mm}$ of growth crowded with very fine commarginal costellae, ca $21 / \mathrm{mm}$; disc often abraded smooth except for weak commarginal growth striae, crossed (where unworn) by extremely fine, close, non-punctate, antimarginal (divaricate) striae, visible under magnification and oblique light, numbering $c a 25 / \mathrm{mm}$ at ventral margin; auricular margin of RV curved due to prominent dorsal extension of anterior auricle; margin of LV straight; auricles of RV unequal, anterior much larger, prominently elevated; byssal fasciole narrow; byssal sinus moderately developed; ctenolium absent; sculpture of very fine, close, commarginal costellae, between which (magnification, oblique light) faint radial striae occasionally visible; weak radial row of low tubercles sometimes present on auricle close to umbonal margin (G2889/9); posterior auricle (RV) a scalene triangle bearing very fine, close, commarginal lamellae; auricles of LV unequal, not elevated; anterior larger, an isosceles triangle bearing numerous very fine growth striae and few obscure, extremely fine radials; posterior auricle (LV) a scalene triangle, arising from buttress flanking umbonal margin; sculptured as anterior auricle, with faint radial striae, more evident on and near buttress. Adductor scars lightly to moderately impressed, subcircular to roundly rectangular, higher than long and rather large, centred high in postero-dorsal quadrant; resilifer (RV) broad, shallow, extending to beak, bounded on each side by oblique crura, convergent on point well above margin; counterparts on LV not seen; pallial line

Dimensions of Syncylonema? sp.

\begin{tabular}{lcc}
\hline Specimens & Length & Height \\
\hline ARI G2775/1, RV interior & 11.0 & 13.2 \\
ARI G2889/1, RV exterior & 8.6 (est.) & 10.8 \\
ARI G2889/2, RV interior & - & 15.6 \\
ARI G2889/4, RV int. mould & 10.8 & 11.9 \\
ARI G2889/5, LV exterior & \multicolumn{2}{c}{ Length of auricular } \\
& \multicolumn{2}{c}{ margin 8.0} \\
\hline
\end{tabular}

Height $=$ beak to ventral extremity. On G2889/1 and G2889/2, anterior auricles extend beyond margins by further 1.2 and $1.0 \mathrm{~mm}$ respectively. Measurements of inflation not possible. 
entire, remote from margin; body cavity usually chalky white, with or without a few obscure radial costellae; internal marginal border brown; shell exterior dark brown.

\section{Remarks}

The species is referred provisionally to the genus Syncyclonema Meek, having regard to the emended diagnosis of Speden (1967: 7-14, pl. 2, fig. 1; 1970: 87 , pl. 17 , figs $12-17$, pl. 18, figs $1-8$ ). Common features with the type species $S$. halli (Gabb) include the small, thin, subvitreous shell, the very fine, non-punctate, antimarginal microsculpture (most apparent around the margins of the disc), the narrow byssal fasciole, moderate byssal sinus, absence of a ctenolium and the large, elevated anterior auricle of the RV. Differences from S. halli include its greater height relative to length, the crowded commarginal costellae of the apical area, that only the RV auricles are distinctly offset from the umbonal margins, the predominance of commarginal sculpture on the auricles and the absence of commarginal internal ribbing.

The present species differs in sculpture and other respects from all of the European species (AptianMaastrichtian) of Syncyclonema in Dhondt (1971) and may be undescribed. Most of the material to hand is fragmentary and often abraded; others are moulds. No intact exterior is known and no specimen is suitable for selection as holotype. Further determination of this species is deferred until better material is available. A similar and possibly related species is Pecten miyakoensis Nagao from the Aptian - ?Albian Hiraiga Formation of southwest Japan, assigned by Hayami (1965a: 318-320, pl. 45, figs 2-11, pl. 46, fig. 5) to the genus Pectinella Verrill. Speden (1967: 24, 25) compared $P$. miyakoensis with the type species of both Syncylonema and Pectinella, noting differences from both in the crural and auricular features and sculpture and from Syncyclonema also in the cardinal area. The relationship of $P$. miyakoensis to the present and other small, smoothshelled Cretaceous pectens requires further study, as noted by Speden.

Pecten (Syncyclonema) obovatus Stoliczka and $P$. (S.) sivaicus Stoliczka from the Uttattur Group (Stoliczka 1871: 435, pl. 32, figs 6-9, pl. 42, fig. 5) and assigned to ?Syncyclonema by Tapaswi (1987), both appear from the auricular features to be distinct from the present species, which indicates a third entoliid in the Uttattur Group.

Syncyclonema is among the genera characteristic of Kauffmann's (1973: 368) North Temperate Realm, corresponding to the MediterranCaucasian Realm of Westermann (2000). Records from the Uttattur Group suggest an extended Cretaceous presence for the genus in or close to the latter's Austral Realm.

\section{Occurrence}

Uttattur Group. Odiyam Localities 1, 2 and 3. Karai Formation (Odiyam and Kunnam Members). Cenomanian.

\section{Family Propeamussiidae Abbott, 1954}

\section{Genus Parvamussium Sacco, 1897}

Variamussium Sacco, 1897

Ctenamusium Iredale, 1929

Glyptamusium Iredale, 1939

Squamamussium Oyama, 1944

Polynemamussium Habe, 1951

(Synonymy after Dijkstra 1995)

\section{Type species}

Pecten (Pleuronectes) duodecimlamellatus Bronn, 1832 , by original designation. Late Miocene, Northern Italy.

\section{Remarks}

In assigning Parvamussium to the Propeamussiidae, we follow studies on the systematics of the Pectinoidea by Waller (1972, $1978,1984)$, in which the family is distinguished from others of the group by the absence of a ctenolium throughout ontogeny and by the presence of prismatic calcite on the RV (Waller 1984: 204, tab. 1). Waller's conclusions regarding Parvamussium and its familial location were upheld from mitochondrial DNA studies by Matsumoto and Hayami (2000).

\section{Parvamussium sp. \\ Figure $11 \mathrm{H}-\mathrm{J}$}

\section{Material examined}

ARI G2699, $13 \mathrm{LVs}$, all interiors, one LV showing decorticated exterior, $22 \mathrm{RVs}$, all interiors, 10 valves of uncertain orientation including three internal moulds, Locality 1; G2774, one internal mould and one interior, of uncertain orientation, Locality 2. Total of 48 single valves.

\section{Description}

Shell small, height to $7 \mathrm{~mm}$, thin, suborbicular, very slightly extended anteriorly and slightly higher than long; compressed, LV probably slightly more inflated than RV; dorsal margin extended, straight; auricles prominent, anterior larger, all lacking crura; resilifer very small, sub-central, bounded (RV) by two minute cardinal crura; byssal notch (RV) present; ctenolium apparently absent; adductor scars large, more or less circular, located high in postero-dorsal quadrant; internal radial 

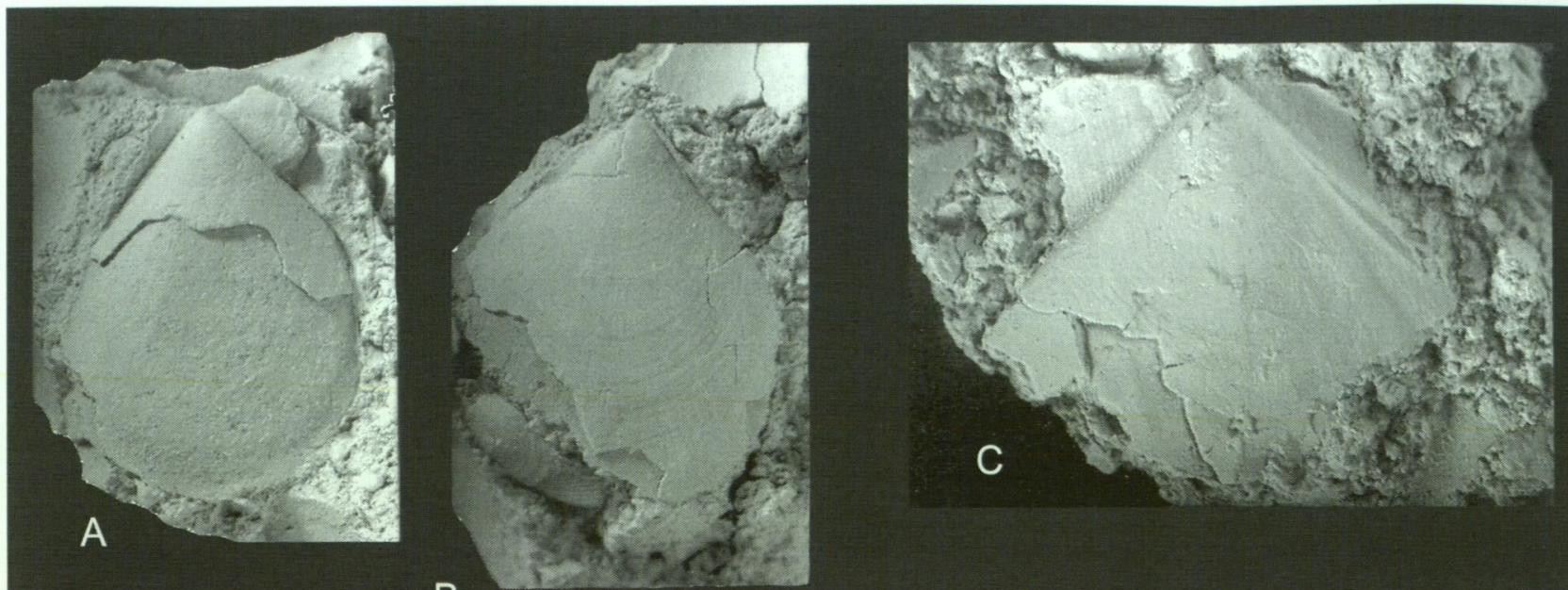

B
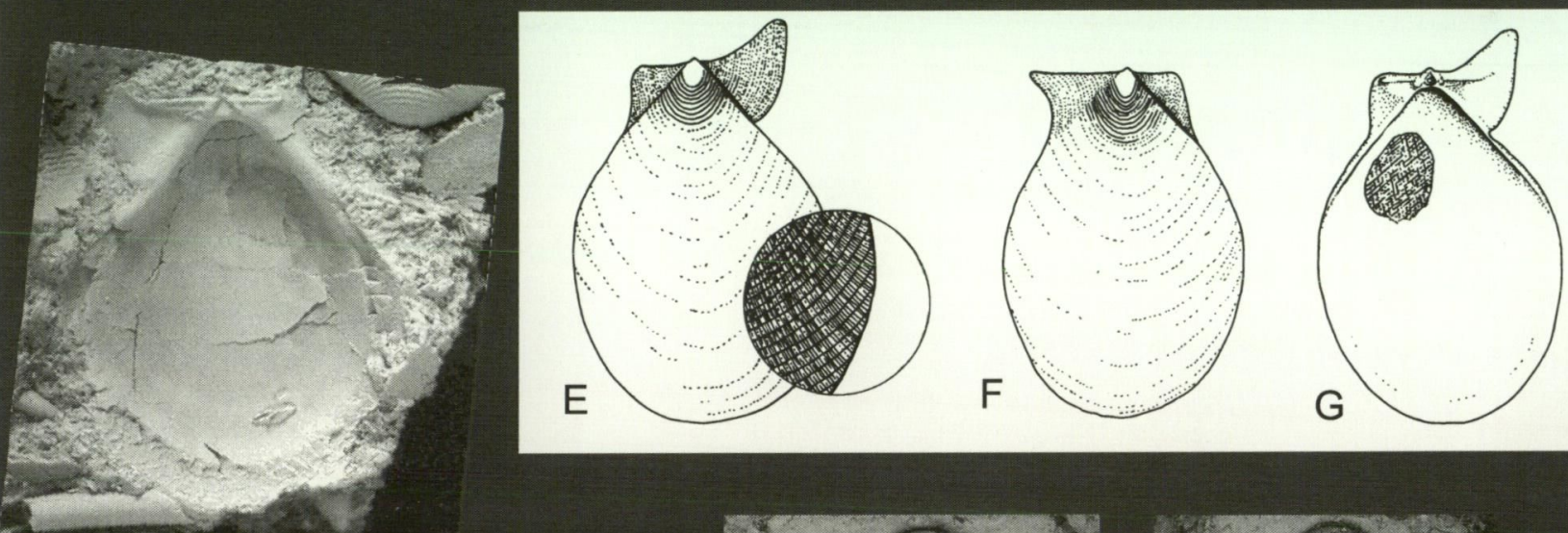

D
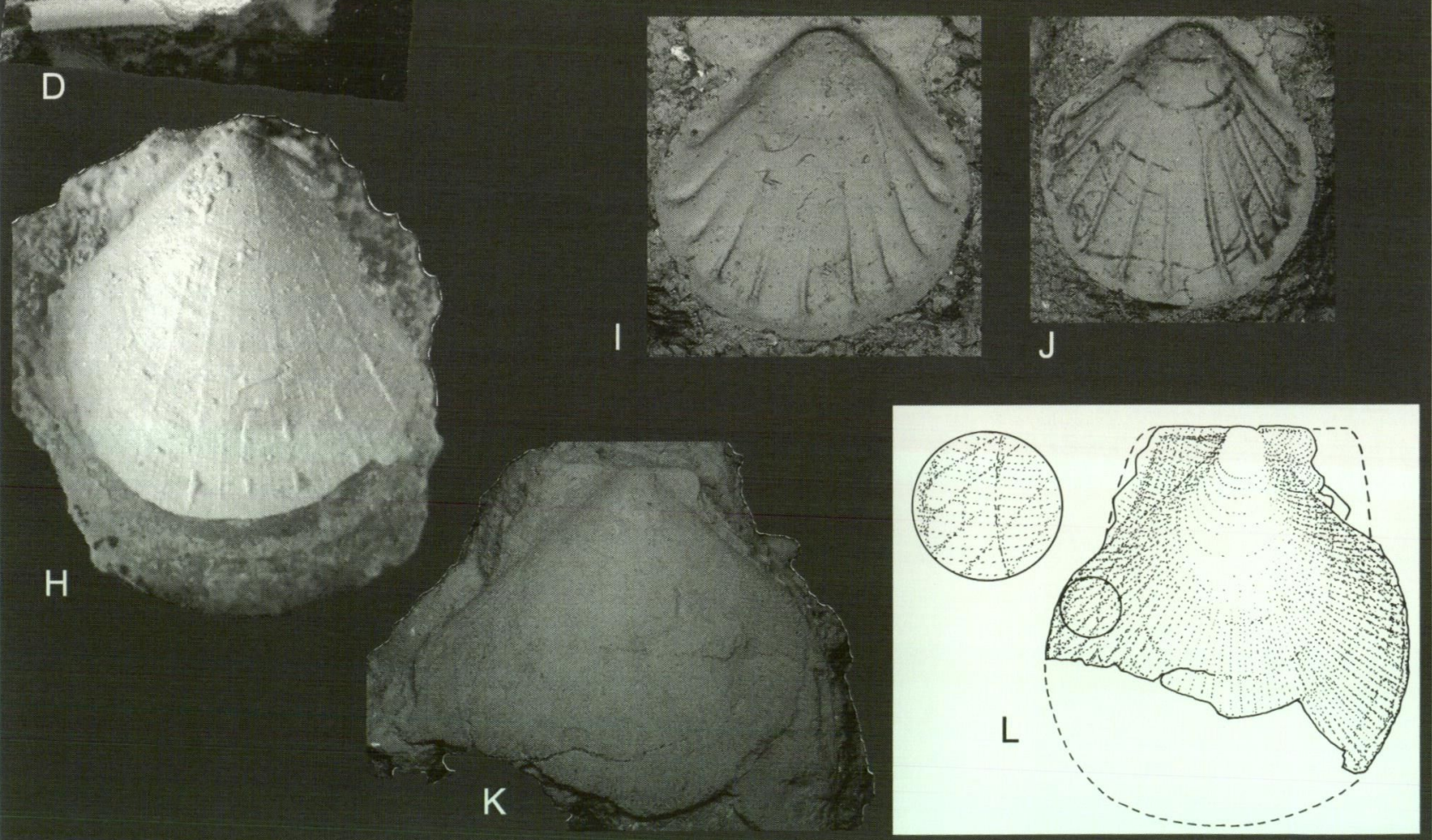

Figure 11 Syncyclonema sp. A ARI G2775/4, RV external x 3. B ARI G2889/8, RV external (auricles missing) x 3. C ARI G2889/5, LV external (dorsal part) x 4. D ARI G2775/3, RV internal x 5. E-G idealised composite drawings based on specimens from Localities 1, 2 and 3. E RV external. F LV external. G LV internal. All aprox. x 2. Parvamussium sp. H ARI G2699/7, LV external x 8. I ARI G2699/1, RV internal x 10. J ARI G2699/3, RV internal x 8. Nippononectes sp. K ARI G2700, RV external x 5. L the same, drawn $x 5$. 
costellae thin, spaced, numbering nine to 12 according to shell size and extending almost to margin; new costellae arising with growth by intercalation; costellae often pigmented in contrast to chalky-white of body cavity; dorsal margin of body cavity arched; anterior margin (body cavity) stronger and more extended than posterior; external sculpture poorly indicated but apparently RV features very fine commarginal lamellae; LV shows very fine radial elements (costellae, micro-striae), with or without commarginal elements; sculpture of auricles unknown; ventral margin internally smooth, bevelled.

Dimensions of Parvamussium sp.

\begin{tabular}{lccc}
\hline Specimens & Length & $\begin{array}{c}\text { Length dorsal } \\
\text { margin }\end{array}$ & Height \\
\hline ARI G2699/1, RV & 3.77 & 2.93 (est.) & 3.92 \\
ARI G2699/2, RV & 6.40 & - & 7.01 \\
ARI G2699/3, RV & 4.20 & 3.34 (est.) & 4.49 \\
\hline
\end{tabular}

Inflation cannot be measured on this material.

\section{Remarks}

The precise nature of the external sculpture of both valves of this species remains uncertain. One LV (G2699/7) is sculptured with fine to very fine radial costellae and little else but the surface seems to be decorticated and may differ from the original exterior. Others, probably RVs and decorticated from the interior, show very fine commarginal lamellae and striae but it is unclear to what extent this might extend to the outer surface. Without knowing the details of the external surfaces of both valves, the specific identity of this species, the first of the genus and family from the Uttattur Group, remains undetermined. Variation in the study material concerns the number of internal ribs.

The present species is related to the wide-ranging (Turonian-Maastrichtian) Parvamussium inversum (Nilsson), differing perhaps in the character of the external sculpture (Dhondt 1971). From $P$. samariensis (Conrad), Late Cretaceous of Jordan, the present species differs in the absence of commarginal intercostal sculpture on the internal surface (Dhondt 1971). A species of Parvamussium, as $P$. sp.cf. $P$. membranaceum (Nilsson), is recorded by Chiplonkar and Tapaswi (1979: 153) from the Santonian-Campanian Sillakkudi Formation.

Table 11 Internal rib counts of Parvamussium sp.

\begin{tabular}{llllccc}
\hline Ribcount & 9 & 10 & 11 & 12 & Indeterminate & Total \\
Total valves & 6 & 19 & 13 & 2 & 8 & 48
\end{tabular}

One specimen (G2699/4) has a small gastropod borehole on the postero-ventral quadrant, visible from the internal surface.

\section{Occurrence}

Uttattur Group. Odiyam Localities 1 (common) and 2. Karai Formation (Odiyam and Kunnam Members). Cenomanian.

\section{Family Neitheidae Sobetski, 1930}

\section{Genus Neithea Drouet, 1824}

\section{Type species}

Pecten aequicostatus Lamarck, 1819, by subsequent designation of Chenu 1862 (Dhondt 1973: 7). Cenomanian, Spain.

\section{Remarks}

Records of species of Neithea from the Indian Cretaceous are dispersed throughout the literature, presenting a disparate and in some respects inconclusive range of taxonomic perceptions. Some species are difficult to distinguish on anything less than well preserved specimens. Others are known from limited material so that intra-specific variation may be unclear. Complex and involved synonymies now attend some species, which may be credited in literature with extensive and possibly inaccurate geographical and stratigraphical ranges. A comprehensive revision and consolidation of these records is called for but lies beyond the scope of this study. A brief summary, drawn from selected pertinent sources, indicates something of the present taxonomic s:ate of the genus in the Cretaceous of India.

Forbes (1846: 153) recorded Pecten quinquecostatus Sowerby, 1814 from "Pondicherry and Verdachellum" (Ariyalur Group, Maastrichtian), the specimens said to be indistinguishable from those from the Blackdown Greensand (Upper Albian). Forbes' specimens were re-determined as Neithea $(N$.) regularis (von Schlotheim) by Dhondt (1973: 26). Under the preLinnaean generic name Vola Klein, 1753, Stoliczka (1871: 437-439, pl. 31, figs 1-6; pl. 37, figs 4-9; pl. 31 , figs 7,8 ) recorded the above Sowerby species and also Janira (?Neithea) laevis Drouet, 1824, the former from the Uttattur, Trichinopoly and Ariyalur Groups, the latter from the Uttattur Group.

Spengler $(1923: 14,15)$ recorded Neithea faujasi (Pictet and Campiche, 1870) from Tharia Ghat, Sokha, Assam. This and other records of $N$. faujasi from NE India were cited by Bhattacharya and Bhattacharya (1987: 377). Because the type of Janira faujasi Pictet and Campiche is the same specimen as that of Pectinites regularis von Schlotheim, 1813 (Dhondt 1973: 20), it would appear that the correct name for these records from NE India is Neithea regularis (von Schlotheim).

In her revision of the European species of 
Neithea, some of which occur also in Asia and Africa, Dhondt (1973: 34) reassessed Stoliczka's concepts of "Vola" quinquecostata, concluding that, "he went too far in his assimilation of species". From an inspection of Stoliczka's figures (1871, pl. 31 , figs $1-6$; pl. 37, figs 4-9) of that species, Dhondt suggested that these might represent up to five species, viz., $N$. quinquecostata, $N$. syriaca (Conrad)? or $N$. coquandi (Péron)?, $N$. regularis (von Schlotheim)?, N. sexcostata (Woodward)? and $N$. gibbosa (Pulteney)?, drawn from the Uttattur, Trichinopoly and Ariyalur Groups. Dhondt relocated "Vola" laevis Drouet of Stoliczka (1871: $438,439$, pl. 31, figs 7,8$)$ in the synonymy of $N$. aequicostata (Lamarck), to make a possible sixth species among Stoliczka's south Indian Neithea. A further Indian record of Neithea by Dhondt (1973: 20 ) is that of $N$. alpina (d'Orbigny) from the Bagh Beds, Narmada Valley.

Though not conclusive, these remarks suggest a likely Tethyan affinity for most of the Indian species of Neithea.

Chiplonkar and Tapaswi (1975b) described Neithea pseudobellula and a subspecies $N$. pseudobellula elevata (each from two RVs only), apparently from an identical horizon of the Uttattur Group and they appear to be the first endemic Indian taxa for the genus. These were compared with $N$. bellula Cragin from the Late AlbianCenomanian of Texas.

Chiplonkar and Joshi (1976) reported a Neithea, as $N$. morrissi (Pictet and Renevier, 1858), from the Cenomanian-Turonian Deola-Chirakhan Marl, Bagh Beds. This name is a synonym of $N$. syriaca (Conrad, 1852) according to Dhondt (1973: 37), but the Indian material, from the description, seems rather variable in characters and the RV sculpture does not agree well with the diagnosis of Conrad's species in Dhondt (1973). This record requires further study.

Chiplonkar and Tapaswi (1977) presented new records of morphologically diverse "Neithea (Neithiops) quinquecostata Sowerby" from the Uttattur, Trichinopoly and Ariyalur Groups. Though unacquainted with Dhondt's (1973) then recently published revision of the European Neithea, they recognised the inadequate status of the genus and species in the Indian literature. It seems possible that their material (none figured) represents, like that of Stoliczka from the same sources, a plurality of species.

Five species of Neithea s. str. are recognised in newly collected material from the Uttattur Group at Odiyam. Four of these, $N$. aequicostata (Lamarck), $N$. cf. hispanica (d'Orbigny), N. gibbosa (Pulteney) and $N$. quinquecostata (J. Sowerby), are identical with or close to species in the Cretaceous of Western Europe and represent a Tethyan-North Temperate element in the south Indian
Cenomanian. The fourth, N. pseudobellula Chiplonkar and Tapaswi, is a south Indian endemic species of uncertain affinity, possibly $\mathrm{N}$ American. None of the Neithea species from the NeocomianAlbian of Japan in Hayami (1965a) appears to be close to our material. The genus, sensu stricto, was cosmopolitan during the Cretaceous, according to Kauffmann (1973). Contrary views on the subdivision of the genus Neithea have been expressed by Hayami (1965a) and Dhondt (1973). We find the latter's conclusions more persuasive and adopt them herein.

\section{Subgenus Neithea s. str.}

Neithiops Stewart, 1930

Aequineithea Hayami, 1965

\section{Neithea (Neithea) aequicostata (Lamarck, 1819)} Figure $12 \mathrm{~A}, \mathrm{~B}$

1819 Pecten aequicostatus Lamarck, pl. 181, no. 13.

1871 Vola laevis Drouet; Stoliczka: 438, 439, pl. 31, figs 7,8 .

1973 Neithea (Neithea) aequicostata (Lamarck); Dhondt: 10-14, pl.1, figs 1a-c. Redescription and synonymy.

1979 Neithea (Neithea) laevis (Drouet); Chiplonkar and Tapaswi: 153, 162.

1993 Neithea (Neithea) aequicostata (Lamarck); Dhondt and Dieni: 190, pl. 4, fig. 15, text fig. 3.

\section{Material examined}

ARI G4340, one conjoined pair, two incomplete $\mathrm{RVs}$ in a hard, pink-brown limestone, Locality 2.

\section{Diagnosis}

RV with 23-36 equal to subequal costae, linear intercostal spaces and smooth, equal auricles; RV moderately to very convex; LV flattened, auricles smooth or finely costellate.

\section{Description (Odiyam specimens)}

Of medium size, length slightly exceeding height, RV moderately convex, LV slightly concave; umbonal angle initially ca $90^{\circ}$, widening to $95^{\circ}$ with growth; RV with 30 smooth, subequal costae separated by linear interspaces; auricles mostly missing, remnant of posterior auricle shows several faint radial costellae; ctenolium distinct, well formed along anterior flank corresponding to byssal notch; LV with two strong, spaced, submedian radial costae and two of lesser prominence toward flanks; additionally across disc are 28 fine costae/ costellae of variable strength, latter arising by intercalation; very fine commarginal threads cross 
radials, most apparent on apical third; auricles finely costellate, anterior with eight, posterior with 16 radials, all crossed by fine, growth lamellae; apical angle (LV) initially $86^{\circ}$, enlarging considerably with growth; internal characters unknown.

Dimensions of Neithea (N.) aequicostata (Lamarck).

\begin{tabular}{rcccc}
\hline Specimens & Length & Height & Inflation & $\begin{array}{c}\text { Apical } \\
\text { angle }\end{array}$ \\
\hline $\begin{array}{r}\text { ARI G4340/1 } \\
\text { pair, RV }\end{array}$ & 35 (est.) & 32.1 & 13 (est.) & $90^{\circ}-95^{\circ}$ \\
$\begin{array}{r}\text { ARI G4340/1 } \\
\text { pair, LV }\end{array}$ & 35 (est.) & 29.4 & - & $86^{\circ}-107^{\circ}$ \\
\hline
\end{tabular}

\section{Remarks}

The study material agrees substantially with Dhondt's (1973) revised diagnosis of Neithea aequicostata. One difference is that the $\mathrm{RV}$ ribs tend to be wider medially and narrower on the flanks; however, no distinction can be seen between principal and intercalary (second order) ribs. LV auricles are both radially costellate, not smooth. The RV sculpture of this material resembles that of $N$. hispanica (d'Orbigny) but that species has fewer ribs (18-22) than $N$. aequicostata (see below). Specimens from "south-east of Odium" and "Coonum", figured by Stoliczka (1871, pl. 31, figs 7, 8) as "Vola" laevis Drouet, have been assigned to the synonymy of $N$. aequicostata, as noted above (Dhondt 1973: 10). Stoliczka's specimens have fewer ribs (22-24) than ours but lie within the range of $N$. aequicostata.

\section{Occurrence}

The species occurs widely in the Albian, Cenomanian and Turonian of Europe and possibly also in the Albian of Japan (Dhondt 1973: 10-14).

Uttattur Group. Stoliczka's (1871) localities (for "Vola" laevis Drouet) are, "Near Kullay, Coonum, Odium and Koloture", all Uttattur Group. Odiyam Locality 2. Karai Formation (Odiyam Member). Cenomanian.

\section{Neithea (Neithea) sp. cf. N. (N.) hispanica (d'Orbigny, 1850) \\ Figure $12 \mathrm{C}, \mathrm{D}$}

cf. 1850 Janira hispanica d'Orbigny: 170 , no. 507.

cf. 1973 Neithea (Neithea) hispanica (d'Orbigny); Dhondt: 14, 15. Redescription and synonymy.

\section{Material examined}

ARI G2891, three LVs (interiors), Locality 3; G2892, two incomplete RVs (one juvenile), Locality 3 . Total five single valves.

\section{Diagnosis [N. (N.) hispanica]}

With 18-22 equal costae and linear interspaces; auricles equal, smooth; areas smooth; LV flattened.

\section{Description}

Odiyam specimens of medium size, length to 41 $\mathrm{mm}$, length and height approximate, RV moderately inflated, LV flattened, slightly raised at anterior and posterior extremities; RV with up to 20 low, smooth, subequal costae and narrow, linear interspaces; principal costae scarcely differentiated from intercalaries, where discernible, the latter number two between principals; costae on flanks slightly narrower than median ones; areas smooth; auricles missing; apical area, hinge and internal characters (RV) unknown; LV (interiors only) with large, radially striate and irregularly shaped adductor scar, centred in postero-dorsal quadrant and extending close to edge of body cavity; pallial line well developed, remote from margin; thickened ridge separates adductor scar and posterior margin; margin internally crenulate with up to 21 short radial costae, corresponding to external costae of $\mathrm{RV}$; auricles subequal, anterior slightly larger; hinge mostly obscured, resilium broad, between two strong, convergent crura; external characters unknown.

Dimensions of Neithea (N.) sp. cf. N. (N.) hispanica (d'Orbigny).

\begin{tabular}{lccc}
\hline Specimens & Length & Height & Inflation \\
\hline ARI G2891/1, LV & 41 (est.) & ca 40 & - \\
ARI G2891/2, LV & 14.84 & 14.50 & - \\
ARI G2891/3, LV & 16.64 & 14.76 & - \\
ARI G2892/1, RV & 27 (est.) & 27 (est.) & 6 (est.) \\
ARI G2892/2, RV & 6.3 & 6.3 & 3.0 \\
\hline
\end{tabular}

\section{Remarks}

The available material is inadequate for full description and determination but clearly belongs with the aequicostata-hispanica group of Neithea. Otherwise similar and readily confused, the species are distinguished by the RV rib count - on aequicostata 23-36, on hispanica 18-22 (Dhondt 1973: 14; A.V. Dhondt, personal communication, 17 Nov. 1995). As far as can be seen, Odiyam shells show up to $20 \mathrm{RV}$ ribs and up to 21 crenulations around the LV margin. RV ribs vary in width, being a little narrower on the flanks than on the central area. These features are consistent with $N$. (N.) hispanica but positive confirmation would require further, better material. Comparing $N$. aequicostata and $N$. hispanica, Dhondt (1973: 15) noted that, "where $N$. hispanica occurs, no $N$. aequicostata is found. $N$. hispanica has a typical Tethysdistribution which continues in the Central African Cretaceous". This distinction is maintained narrowly in the present material, in that $N$. 
aequicostata is present at Odiyam Locality 2 (Odiyam Member) and $N$. sp. cf. hispanica at Locality 3 (Kunnam Member).

\section{Occurrence}

Uttattur Group. Odiyam Locality 3. Karai Formation (Kunnam Member). Cenomanian. Uncommon. $N$. (N.) hispanica occurs in the Albian of Angola and Cenomanian of N Africa, Spain and France (Dhondt 1973: 15).

\section{Neithea (Neithea) gibbosa (R. Pulteney, 1813)} Figure $12 \mathrm{E}$

1813 Pecten gibbosus R. Pulteney: 107, pl. of Melbury fossils, fig. 2.

1814 Pecten quadricostata J. Sowerby: 121, pl. 56, figs 1,2 .

1973 Neithea (Neithea?) gibbosa (R. Pulteney); Dhondt: 55-59, pl. 2, fig. 3. Redescription and synonymy.

1977 Neithea (Neithiops) quinquecostata (J. Sowerby) (pro parte); Chiplonkar and Tapaswi: 200-202.

\section{Material examined}

ARI G2890, immature RV, Locality 3.

\section{Diagnosis}

RV with six principal costae and ca 18 second order (intercalary) costae, grouped usually in threes, sometimes (toward flanks) in fours; costae, interspaces and auricles commarginally striated; auricles subequal, posterior larger.

\section{Description}

Small, immature RV, symmetrical about midline, higher than long, gibbous; umbo acline, strongly incurved; beak, hinge and interior obscured; umbonal angle ca $63^{\circ}$; auricles subequal, posterior slightly larger; sculpture of rounded radial costae, mostly slightly wider than channelled interspaces; principal costae six, more differentiated on umbo, less so with growth; between principal costae are 18 intercalary costae/costellae with three finer costellae on anterior area, two on posterior area. Disposition of radial sculpture (RV) shown thus:

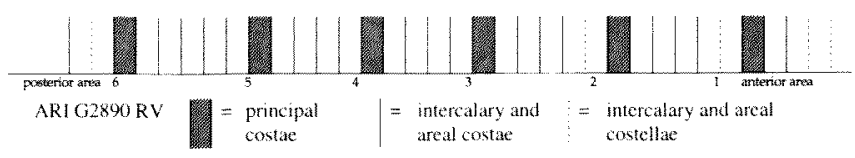

Areas mostly smooth; entire surface including auricles bears fine, close, regularly spaced, growth striae, visible under magnification; LV not seen.
Dimensions of Neithea (N.) gibbosa (R. Pulteney).

\begin{tabular}{lccc}
\hline Specimens & Length & Height & Inflation \\
\hline ARI G2890, RV & 20.04 & 22.06 & 12.44 \\
\hline
\end{tabular}

\section{Remarks}

Though immature, the specimen agrees substantially with the diagnosis and variability of Neithea (N.) gibbosa in Dhondt (1973: 57). It differs in having, close to principal costae 1 and 6 , additional areal radials (three anterior, two posterior). The significance of these may become clearer from a wider range of south Indian material. The species differs from $N$. (N.) regularis (von Schlotheim) by its smooth, unequal auricles and smooth outwardly bent areas (Dhondt 1973: 24).

Dhondt (1973: 34) suggested that the specimen from "Trichinopoly" figured by Stoliczka (1871, pl. 37 , fig. 8) may belong to $N$. gibbosa. The same species is recorded also by Dhondt (1973: 59) from "Bagh Beds, Nerbuddha [=Narmada Valley] B.M.". Neithea attockensis Cox, from the Albian of Attock district, Pakistan (Cox 1935), shows "a strong similarity to $N$. gibbosa" according to Dhondt (1973: 58). RV rib counts on Cox's species range from 21-23 or 24 (Cox 1935: 21).

\section{Occurrence}

Uttattur Group. Odiyam Locality 3. Karai Formation (Kunnam Member). Cenomanian. Rare. Bagh Beds. Turonian. Also Cenomanian of western and central Europe, Israel, Angola.

\section{Neithea (Neithea) quinquecostata (J. Sowerby, 1814)}

Figure $12 \mathrm{~F}-\mathrm{I}$

1814 Pecten quinquecostata J. Sowerby: 122, 123, pl. 56 , figs 4-8.

1871 Vola quinquecostata (Sowerby); Stoliczka: 437, 438, pl. 31, figs 1-6, pl. 37, figs 4-9 (pro parte).

1973 Neithea (Neithea) quinquecostata (J. Sowerby); Dhondt: 29-37, pl. 2, figs 2a-c. Synonymy and revision.

1977 Neithea (Neithiops) quinquecostata (Sow.); Chiplonkar and Tapaswi: 200-202.

1979 Neithea (Neithiops) quinquecostata (Sow.); Chiplonkar and Tapaswi: 143-145, 154, 162.

1993 Neithea (Neithea) quinquecostata (J. Sowerby); Dhondt and Dieni: 194-196, pl. V, figs 1-3.

\section{Material examined}

ARI G2701, four RVs (fragmentary), three LVs (interiors only), Odiyam Locality 1; G2835, three RVs (juvenile), one LV, Locality 2; WAM 88.482, one conjoined pair, 4 RVs, Sattanur. Total of 15 


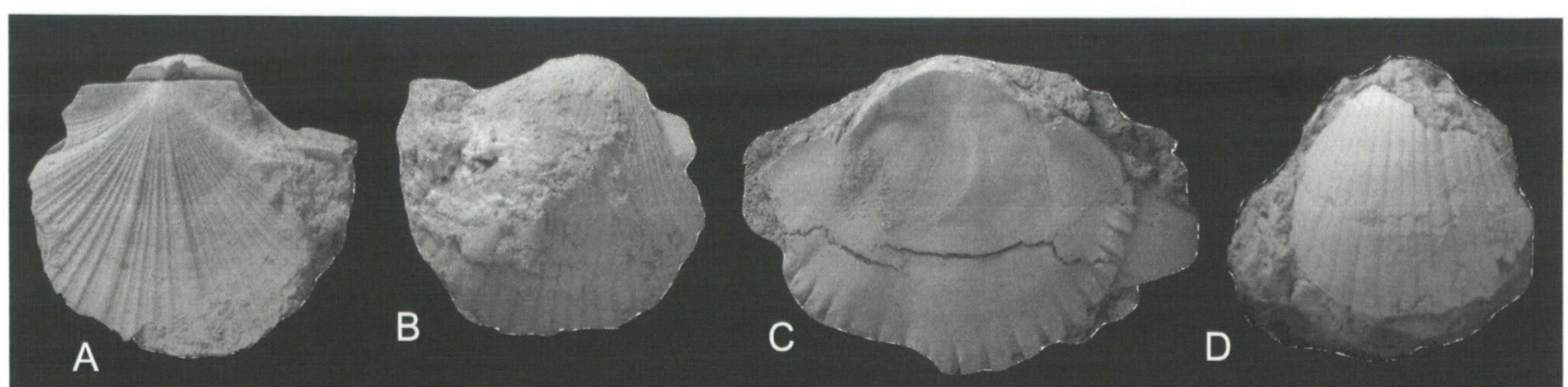

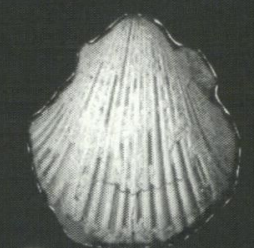

E

F

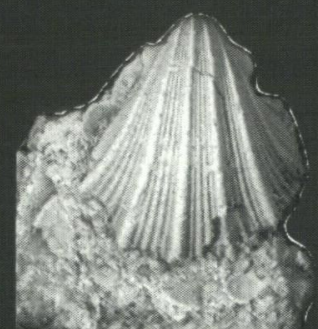

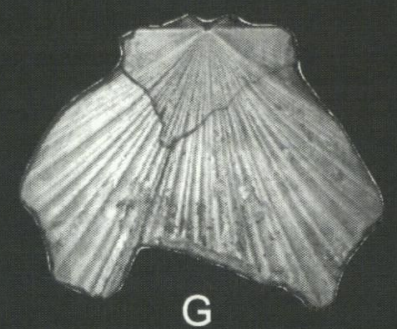

G
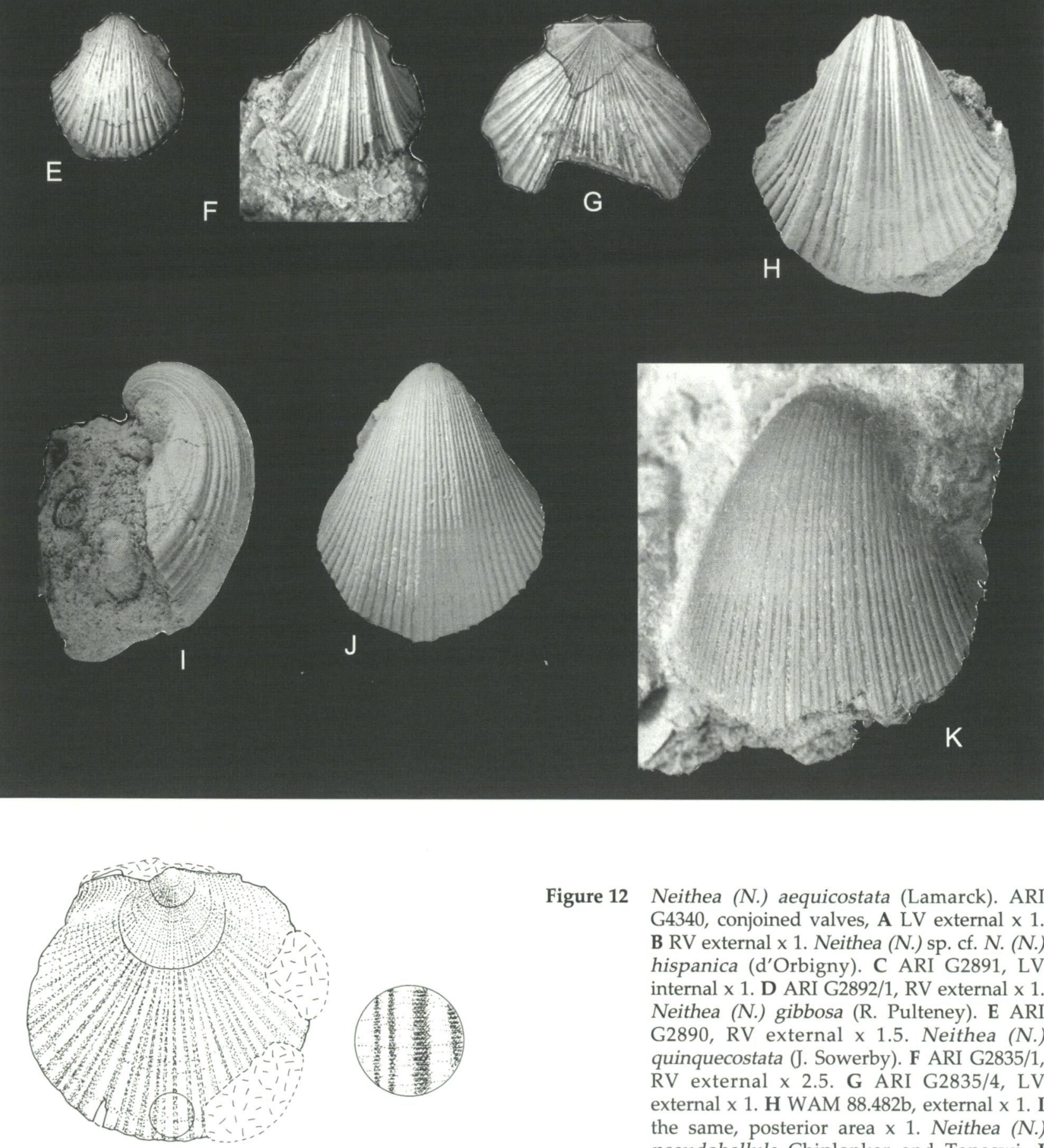

Figure 12 Neithea (N.) aequicostata (Lamarck). ARI G4340, conjoined valves, A LV external x 1. B RV external x 1. Neithea (N.) sp. cf. N. (N.) hispanica (d'Orbigny). C ARI G2891, LV internal x 1. D ARI G2892/1, RV external x 1. Neithea (N.) gibbosa (R. Pulteney). E ARI G2890, RV external x 1.5. Neithea (N.) quinquecostata (J. Sowerby). F ARI G2835/1, RV external x 2.5. G ARI G2835/4, LV external x 1 . H WAM 88.482 b, external x 1 . I the same, posterior area $\times 1$. Neithea (N.) pseudobellula Chiplonkar and Tapaswi. J ARI G4352/1, RV external x 4. K ARI G4352/ 4, RV external x 4.8. Neithea (N.) sp. cf. Neithea (N.) pseudobellula Chiplonkar and Tapaswi. L ARI G4353, LV external x 5. 
single valves and one pair.

\section{Diagnosis}

Medium to large Neithea s. str. (study material mostly juvenile); RV with six prominent principal costae, between each pair of which are usually four intercalary costae; where intercalaries exceed four, these occur in outer intercostal sectors; where intercalaries are less than four, these occur in median sectors; LV slightly concave with 34 radial costae (G2835/4) of variable strength and spacing; new costae arise by bifurcation; auricles with fine radial striae (after Dhondt 1973: 33).

\section{Description (Odiyam specimens)}

RV triangularly sub-ovate, higher than long, narrowed dorsally, maximum length on ventral half; umbo orthogyrate, gibbous, elevated, subtending angle of $50^{\circ}$; beak incurved, transgressing short dorsal margin; auricles short, sub-equal. Sculpture of six principal costae, mostly with four intercalary costae between each pair (see diagram below); four anterior and four posterior areal costae/costellae present; auricles with very fine commarginal and radial microsculpture, stronger on posterior auricle; interior obscured. LV triangularly subovate, flat (juvenile), becoming slightly concave with growth; height slightly exceeding length; umbo recessed, orthogyrate, subtending angle of $106^{\circ}$; auricles equal, concave; dorsal margin short, straight; sculpture of 34 radial costae of variable strength and spacing with channelled interspaces; new radials arise by bifurcation; microsculpture of crowded, growth striae; auricles with numerous growth striae and weak radials, two anterior and four posterior; hinge median with two strong, striated cardinals, divergent about ligamental pit and extending above margin; dorsal margin straight, internally vertically striate; margins (except dorsal) crenulate; adductor scar subcircular, centred high in postero-dorsal quadrant; internal margin grey, interior otherwise chalky white.

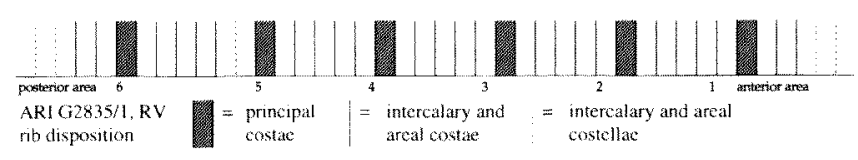

Dimensions of Neithea (N.) quinquecostata (J. Sowerby).

\begin{tabular}{|c|c|c|c|c|}
\hline Specimens & Length & $\begin{array}{l}\text { Length } \\
\text { hinge } \\
\text { margin }\end{array}$ & Height & Inflation \\
\hline ARI G2701/2, LV & 17.86 & 8.90 & 18.58 & - \\
\hline ARI G2835/1, RV & 9.12 & 5.0 (est.) & 10.18 & 5.7 \\
\hline ARI G2835/4, LV & 37.3 (est.) & 16.5 (est.) & - & 4.4 \\
\hline WAM $88.482 b, R V$ & 27.74 & - & 31.0 & 13.5 \\
\hline
\end{tabular}

\section{Remarks}

This very long-ranging (Barremian to Late Maastrichtian) and widely dispersed species was revised in some detail by Dhondt (1973). Most records are from northern Europe and the Mediterranean region (Algeria, Syria, Jordan) with peripheral occurrences in South Africa and south India. These lie within the MediterranCaucasian Realm of Westermann (2000), the lastmentioned adjoining the Austral Realm boundary. Indian records of Neithea (N.) quinquecostata, some seemingly in need of reevaluation, have been discussed above (see Chiplonkar and Tapaswi 1973, Dhondt 1973). Five specimens of this species (WAM 88.482) from calcareous sandstone of the Kulakkalnattam Formation (Turonian) of Sattanur are typical examples of $N$. (N.) quinquecostata (Fig. $12 \mathrm{H}, \mathrm{I}$ ). Chiplonkar and Tapaswi (1979: 162) report the species from Pondicherry and elsewhere.

\section{Occurrence}

Uttattur Group. Stoliczka's (1871) localities were "North of Odium, Cullapaudy, Moraviatoor, Ootatoor, south of Puravoy". The Maruvattur record may represent the Albian Dalmiapuram Formation, the others the mainly Cenomanian Karai Formation. Odiyam Localities 1 and 2. Karai Formation (Odiyam and Kunnam Members). Cenomanian.

Trichinopoly Group. From "south-east of Permapalliam, east and north-east of Anapaudy; south of Serdamungalum" (Stoliczka 1871). These may derive from the Turonian-Coniacian Anaipadi Formation. "Shelly Limestone ... about $1.5 \mathrm{~km}$ NE of Alundalipur, $2 \mathrm{~km} \mathrm{NW}$ of Saradamangalam" (Chiplonkar and Tapaswi 1973). These records may represent the Kulakkalnattam Formation (Turonian) and Anaipadi Formation (Coniacian) respectively. Chiplonkar and Tapaswi (1973) recorded the present species from "Earthy limestone from Uttatur Group at about $1.5 \mathrm{~km}$ SE of Sattanur". Perusal of the geological map (Fig. 1) suggests a more likely source within the Trichinopoly Group, either Kulakkalnattam (Turonian) or Anaipadi (Coniacian) Formation.

Ariyalur Group. Stoliczka's (1871) localities for this species were, "east and west of Arrialoor; south-east of Mulloor, Shillagoody, and Olapaudy". Possibly (part) Sillakuddi Formation. Santonian-Campanian. "Calcareous grits ... at about a $\mathrm{km}$ south of Mallur, $1 \mathrm{~km} \mathrm{NE}$ of Ariyalur" (Chiplonkar and Tapaswi 1973). Sillakuddi Formation. Santonian-Campanian. A record from "Verdachellum", ex Forbes in Dhondt (1973: 37) may be of Campanian or Maastrichtian age. 
Neithea (Neithea) pseudobellula Chiplonkar and Tapaswi, 1975

Figure $12 \mathrm{~J}-\mathrm{L}$

1975 Neithea (Neithea) pseudobellula Chiplonkar and Tapaswi : 135, 136, pl. 3, fig. 8 .

1975 Neithea (Neithea) pseudobellula elevata Chiplonkar and Tapaswi: 136, pl. 3, fig. 9.

1979 Neithea (Neithea) pseudobellula Chiplonkar and Tapaswi: 138, 153.

1987 Neithea (Neithea) psuedobellula [sic] Chiplonkar and Tapaswi; Tapaswi: 508. List only.

\section{Material examined}

\section{Lectotype}

Here designated. ARI Od 80/70. RV from "Earthy limestone from Uttatur Group at about $2 \mathrm{~km} \mathrm{NE}$ of Odiyam" (Chiplonkar and Tapaswi 1975).

\section{Paralectotype}

ARI Od 82/70. RV from type locality.

\section{Other material}

ARI G2977, juvenile RV, Odiyam Locality 3; G4352, four juvenile RVs, Locality 2; G4353, one juvenile LV, Locality 2 . Total of six single valves.

\section{Diagnosis (revised)}

Small Neithea s. str., height to $17 \mathrm{~mm}$, slightly higher than long; RV triangularly ovate, gibbous, with 36-42 radials (including areal costellae), with or without weak differentiation into primary and intercalary costae; where present, primaries number six, between each pair of which are five or seven intercalaries; costae may be simple, bifurcate or grooved on crests; interspaces channelled, usually narrower than costae; auricles subequal, posterior slightly larger and with faint radial costellae; LV subcircular, slightly concave, with ca 45 low radials of variable strength and spacing, not obviously differentiated. RV protoconch I smooth, II commarginally wrinkled.

\section{Original Description}

"The shell is rather tumid with anterior and posterior margins feebly concave. The RV carries almost equally strong, 38-40 radial ribs separated by less wide concave furrows, one or two of which being wider than others give an appearance of grouping of ribs" (Chiplonkar and Tapaswi 1975: 136).

From the same locality and lithology as the present species, the authors described Neithea (N.) pseudobellula elevata subsp. nov., distinguished by fewer radials (30-35) and a taller, more convex RV (Chiplonkar and Tapaswi 1975).
The lectotype of Neithea pseudobellula is somewhat crushed and incomplete dorsally; it has 38 weakly differentiated radials. The paralectotype is also incomplete dorsally and is overlain by sediment ventrally and on the areas; it shows 34 visible radials. The type material of $N$. pseudobellula elevata comprises two RVs but a collection search at Pune in February 1998 succeeded in locating only one of these, ARI Od $106 / 70$. It is worn, incomplete dorsally and the flanks are obscured by hard, pale brown limestone; ca 25 radials, weakly differentiated, are discernible but the total number is undetermined. Radials are a little wider and more spaced than on the type material of $N$. pseudobellula s. str. but are otherwise similar. $N$. pseudobellula is said to differ from N. bellula Cragin, Albian - ?Cenomanian of Texas, in its less distinct grouping of ribs (Chiplonkar and Tapaswi 1975). Erected on limited material, it is the first endemic species of Neithea to be recognised from the Indian Cretaceous.

The study material (five RVs, one LV, all immature) from Odiyam enables the species to be defined in more detail. ARI G2977 has been compared with the type material of Neithea pseudobellula and is considered to be conspecific. The simple, weakly differentiated radials total 40 (six primaries, 27 intercalaries, seven areal) and are, with some variation, approximate in width to the channelled interspaces; auricles damaged, apparently smooth. Disposition of the radials is shown in the following diagram:

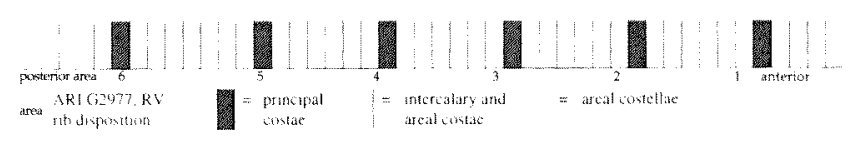

RV G4352/1 is broken anteriorly, retaining 38 radials, slightly wider than interspaces and without obvious differentiation; auricles missing. RV G4352/ 2 resembles the foregoing, with ca 43 radials of variable width; ribs 18 and 23 are slightly more elevated than the others. Posterior auricle is larger and bears five very faint radials; both auricles with very fine, close, commarginal growth striae; protoconch I smooth, protoconch II $(0.3-0.7 \mathrm{~mm})$ with seven wrinkled, commarginal micro-striae, after which primary costae develop but do not persist. RV G4352/3 has about 40 radials of variable width, not obviously differentiated, with several bearing crestal grooves; anterior auricle with very fine commarginal striae; posterior auricle broken. RV G4352/4 shows 39 radials, probably with others on each flank concealed; none obviously differentiated; most radials strongly bifid and wider than interspaces; auricles concealed. LV G4353 is about as long as high, subcircular, slightly concave, with ca 45 fine, low radials of variable width and spacing, mostly wider than interspaces; new costae 
arise by intercalation. There is no obvious differentiation of costae into primary or intercalary rank. Auricles smooth, posterior larger. Internal surface obscured. This specimen is referred provisionally to Neithea pseudobellula from its comparable sculpture to that of the RV. The LV of the species has not been described hitherto.

In assigning the foregoing material to Neithea pseudobellula, we conclude tentatively that the subspecies elevata represents one more sculptural variant in an otherwise variable species. Our study material is immature and positive determination is subject to confirmation from a wider range of more mature specimens.

Dimensions of Neithea (N.) pseudobellula Chiplonkar and Tapaswi.

\begin{tabular}{lccc}
\hline Specimens & Length & Height & Inflation \\
\hline $\begin{array}{c}\text { ARI Od 80/70, RV, } \\
\text { lectotype }\end{array}$ & ca 15 & $16.7^{*}$ & ca 13 \\
$\begin{array}{c}\text { ARI Od 82/70, RV, } \\
\text { paralectotype }\end{array}$ & 13.5 (est.) & $14.4^{*}$ & 7.4 (est.) \\
ARI G2977, RV & 9.10 & 11.26 & 5.4 \\
ARI G4352, RV & 8.24 & 9.30 & ca 4.8 \\
ARI G4353, LV & 9.22 & 9.14 & - \\
\hline
\end{tabular}

* denotes specimens incomplete dorsally

\section{Occurrence}

Uttattur Group. Earthy limestone ca $2 \mathrm{~km} \mathrm{NE}$ of Odiyam (type). Odiyam Localities 2 and 3. Karai Formation (Odiyam and Kunnam Members). Cenomanian. Uncommon.

\section{Family Pectinidae Rafinesque, 1815}

\section{Subfamily Camptonectinae Habe, 1977}

\section{Genus Nippononectes Tashiro, 1982}

\section{Type species}

Chlamys (s. l.) tamurai Tashiro, 1976, by original designation. Campanian-Maastrichtian, southwest Japan.

\section{Nippononectes sp. \\ Figure $11 \mathrm{~K}, \mathrm{~L}$}

\section{Material examined}

ARI G2700, RV lacking ventral third and most of anterior auricle, Locality 1.

\section{Description}

Small, probably immature RV, higher than long; umbo inflated, acline, margins well defined, the anterior distinctly concave, posteriorly almost straight and together subtending angle of about $90^{\circ}$; dorsal margin, where retained, straight; beak worn but originally probably extended slightly beyond margin; posterior auricle a scalene triangle, somewhat extended along umbonal flank; anterior auricle mostly missing, retaining narrow (?) fasciole and ctenolium; apical area worn smooth; medianumbonal area smooth except for faint, commarginal striae; remainder of disc with radial sculpture of two kinds, (a) fine, low, slightly irregular costellae, divergent from beak, most evident on posterior flank, fading anteriorly, and (b) numerous, very fine, crowded, anastomosing, antimarginal (=divaricate) costellae, non-punctate, crossing radials and most evident on flanks; antimarginals extend onto posterior auricle, which also has faint, commarginal micro-striae; proximal remnant of anterior auricle very finely reticulate with radial and commarginal striae; growth-pause lines prominent. Internal characters of RV and entire LV unknown.

Dimensions of Nippononectes sp.

\begin{tabular}{lccc}
\hline Specimens & Length & Height & Inflation \\
\hline ARI G2700, RV & 8.82 & 9.5 (est.) & 1.5 (est.) \\
\hline
\end{tabular}

\section{Remarks}

The genus Nippononectes was erected by Tashiro (1982) for four small, Early Aptian to Maastrichtian Japanese pectens. The original generic diagnosis is: "Shell small to medium in size, roundly ovate, inequivalve; test thin; umbo located nearly midpoint of valve length; byssal notch deep in right valve with several ctenolia; external surface ornamented with two sorts of ribs; one is radial ribs, spinose generally on ventral part, more numerous on left valve than in right valve; the other ribs are divaricate striae; ears ornamented in the same way as the disc; two pair of cardinal crurae [sic] present; a pair of crurae [sic] of either sides of resilifer; the other pair of cardinal crurae [sic] below the hinge line, parallel to cardinal axis; inner surface smooth; inner margin smooth".

"The new genus is characterised by Camptonecteslike divaricated striae and Camptochlamys-like radial ribs on the surface. The divaricated striae are very abundant and developed on entire surface of the valve. The radial ribs are round-topped, delicate but distinct, generally narrower than their interspaces, crowded on both lateral parts of the valve, and stronger and less numerous than the divaricated striae" (Tashiro 1982).

In all available characters, the present species agrees well with Tashiro's genus, of which it would appear to be a south Indian Cenomanian representative. Of the Japanese species, it most resembles (RV) Nippononectes tamurai (Campanian-Maastrichtian), differing in its larger apical angle, larger posterior auricle (RV) and 
fewer, wider, commarginal costellae. In view of the discrepant sculpture of the valves on the Japanese species, the LV of the Odiyam species, when found, may differ in this respect from the RV.

Western Australian occurrences of Nippononectes have been reported (as Nipponectes, err.) from the Maastrichtian Miria Formation and Santonian Gingin Chalk by Darragh and Kendrick (1991: 5862, fig. 12C, F). From these, the south Indian species differs in its wider apical angle, larger posterior auricle (RV) and fewer, much wider antimarginal costellae; in essential sculpture of the RV, these species appear to be congeneric and suggest a wideranging presence for Nippononectes throughout the Late Cretaceous.

\section{Occurrence}

Uttattur Group. Odiyam Locality 1. Karai Formation (Kunnam Member). Cenomanian. Rare.

\section{Subclass Heterodonta Neumayr, 1884}

\section{Order Veneroida H. and A. Adams, 1856}

\section{Superfamily Lucinoidea Fleming, 1828}

\section{Family Lucinidae Fleming, 1828}

\section{Remarks}

Seven species of Lucinidae have been described from the Cretaceous of south India, mostly from the Ariyalur Group, by Forbes (1846) and Stoliczka (1871). These, in their original combinations and origins, are:

Lucina jugosa Forbes

L. fallax Forbes

\section{L. (Codakia) percrassa Stoliczka}

L. undata Stoliczka

L. (Cyclas) taeniolata Stoliczka

L. (Myrtea) arcotina Stoliczka

\section{L. (Myrtea) dentigera Stoliczka} Ariyalur Group (see below) " " " " $"$ "

Uttattur,

Trichinopoly and Ariyalur Groups Ariyalur Group Of these, Lucina (Codakia) percrassa and Lucina (Cyclas) taeniolata are from "Ninnyoor, in white limestone. Arrialoor Group", now assignable to the Lower Paleocene (Danian) Niniyur Formation (Sundaram et al. 2001) and can be deleted from any listing of Cretaceous fauna.

Additional to the above, Stoliczka (1871) recorded "Lucina fallax Forbes" from "a dark brown earthy limestone near Moraviatoor" and "a single specimen ... from the white limestone near Ninnyoor", noting four "varieties" in his material. The former probably derive from the Albian Dalmiapuram Formation, the latter from the Paleocene Niniyur Formation.

Having examined and compared the above-listed
Table 12 Specimens of "Lucina fallax Forbes", GSI Stoliczka Collection, Kolkata.

$\begin{array}{lll}\text { GSI } & \text { Locality } & \text { Figured } \\ \text { no. } & \text { and Group } & \text { Stoliczka } \\ & & \mathbf{( 1 8 7 1 )}\end{array}$

\begin{tabular}{lll}
\hline 1099 & Maruvattur, Uttattur Group & pl. 13, fig. 13 \\
1101 & Maruvattur, Uttattur Group & pl. 13, fig. 15 \\
1102 & Maruvattur, Uttattur Group & pl. 13, fig. 16 \\
1103 & Niniyur, Ariyalur Group & pl. 13, fig. 17 \\
1106 & near Maruvattur, Uttattur Group & pl. 14, figs 3-5 \\
1108 & Maruvattur, Uttattur Group & pl. 14, figs 3-5 \\
1110 & near Maruvattur, Uttattur Group & pl. 14, fig. 7 \\
1111 & near Maruvattur, Uttattur Group & pl. 14, fig. 8
\end{tabular}

specimens at GSI, Kolkata and also the type material of Lucina fallax Forbes at the Natural History Museum, London, we conclude that the former represent a plurality of both lucinid and astartid species, none of which is conspecific with L. fallax Forbes, a lectotype for which is designated below. "Lucina jugosa Forbes" appears to be an astartid (Tapaswi 1987). It is clear that the south Indian Cretaceous lucinids are much in need of taxonomic revision, to which the present study may contribute.

\section{Subfamily Lucininae Fleming, 1828}

Genus Callucinopsis Chavan, 1959

Type species

Lucina foucardi Deshayes, 1858, by original designation. Paleocene, France.

\section{Callucinopsis? dalmiana sp. nov. Figure $13 \mathrm{~A}-\mathrm{C}$}

\section{Material examined}

\section{Holotype}

ARI G2906/1, conjoined pair from hard, greyishbrown, quartzose, Trigonarca-rich limestone, by nullah ca $1.0 \mathrm{~km}$ south of Odiyam village, Perambalur Taluk, Tiruchirapalli district, Tamil Nadu (Locality 3).

Paratypes

ARI G2906/2-12, three conjoined pairs, four LVs, four RVs, from type locality. Total of 12 specimens.

\section{Diagnosis}

Small for genus, up to $12 \mathrm{~mm}$ long, robust, lenticular, umbones elevated; length approximate to height; anterior area obsolete, posterior area weakly defined; sculpture commarginal only; anterior adductor scar long; margin finely crenulate. 


\section{Description}

Small, robust, lenticular, about as long as high, sub-equilateral to slightly extended anteriorly, moderately inflated; umbones median, elevated, slightly prosogyrate; beaks acute, touching, prosogyrate; anterior area obsolete, posterior area weakly defined; lunule short, broad, excavate, RV overlapping LV; escutcheon lanceolate, recessed, occupying entire postero-dorsal margin, bordered by angulation; ligament marginal, externally visible along two thirds of escutcheon, internally set on strong nymph; LV cardinal thin, vertical; $4 \mathrm{~b}$ stronger, oblique, fused to nymph; RV cardinal $3 b$ strong, triangular, oblique, slightly bifid; $3 a$ obscured; laterals obscured; anterior adductor scar moderately long, descending to ca mid-height (G2906/10), sub-parallel to pallial line; posterior scar broader, spadiform; pallial line entire, well defined, remote from margin, which internally is very finely crenulate. Sculpture of very fine, close, slightly irregular, commarginal costellae with occasional growth steps; radial sculpture absent; antero-dorsal margin slightly concave; postero-dorsal margin slightly convex; posterior margin slightly truncate; other margins evenly rounded.

Dimensions of Callucinopsis? dalmiana sp. nov.

\begin{tabular}{lccc}
\hline Specimens & Length & Height & Inflation \\
\hline $\begin{array}{c}\text { ARI G2906/1, conjoined } \\
\text { pair, holotype }\end{array}$ & 10.78 & 10.78 & 5.60 \\
ARI G2906/3, LV, paratype & 12.15 & 12.06 & - \\
ARI G2906/6, RV, paratype & 10.22 & 10.27 & 2.7 (est.) \\
\hline
\end{tabular}

\section{Remarks}

The present generic location for this distinctive and uncommon species remains subject to confirmation as further details of the dentition and musculature become available. The internal characters have been deduced from moulds, none of which is suitable for figuring. As seen on one of the paratypes, the anterior adductor scar would appear to exceed in length that of Callucinopsis foucardi (Deshayes) but all other known characters are consistent with inclusion in the genus Callucinopsis. Almost one third of the material to hand comprises conjoined pairs, suggesting a stabilised, deep-burrowing habit in life, at or close to the point of collection (type locality). No evidence of gastropod predation is apparent.

According to Kauffmann (1973: 361), Callucinopsis is among the genera/subgenera characteristic of "the entire Indo-Mediterranean Region" during the Cretaceous. Chavan (in Moore 1969: N494) records it from the "Senonian".

\section{Etymology}

We have pleasure in naming this distinctive species after the Dalmia Cement Company in appreciation of its generous support through its Dalmiapuram facility for field work in the Cauvery Basin during 1981, 1983 and 1989.

\section{Occurrence}

Uttattur Group. Odiyam Locality 3. Karai Formation (Kunnam Member). Cenomanian. Uncommon.

\section{Genus Callucinella Chavan, 1961}

\section{Type species}

Lucina albella Lamarck, 1806, by original designation. Lutetian, France.

\section{Callucinella marcida sp. nov. Figure $13 D-G$}

\section{Material examined}

\section{Holotype}

ARI G2782/1, RV, from brown calcareous siltstone with abundant turritellid gastropods, beside track ca $0.5 \mathrm{~km}$ west of Odiyam village, Perambalur Taluk, Tiruchirapalli district, Tamil Nadu (Locality 2).

\section{Paratypes}

ARI G2782/2-13, three LVs, eight RVs, one conjoined pair, from the type locality. Total of 13 specimens.

\section{Other material}

ARI G2782/14-25, 11 single valves from the type locality.

\section{Diagnosis}

Small, thin-shelled, subequilateral, lenticular, areas obsolete; sculpture commarginal, weak, stepped, obsolete on beaks; lunule shallow.

\section{Description}

Small, up to $12 \mathrm{~mm}$ in length, thin-shelled, lenticular, slightly oblique, usually slightly longer than high with slight anterior extension; areas obscure, anterior occasionally discernible; anterodorsal margin short, concave; postero-dorsal margin longer, slightly convex; umbones broad, elevated; beaks acuminate, prosogyrate, submedian; lunule well defined, long, shallow, asymmetric, RV overlapping LV; escutcheon lanceolate, shallow; ligament marginal, visible on bivalve; sculpture of low, unevenly spaced, stepped, commarginal ridges, slightly foliaceous along antero-dorsal margin, with very fine, crowded, commarginal, micro-striae in interspaces; sculpture obsolete on beaks (apical $4 \mathrm{~mm}$ ); well preserved shells show 


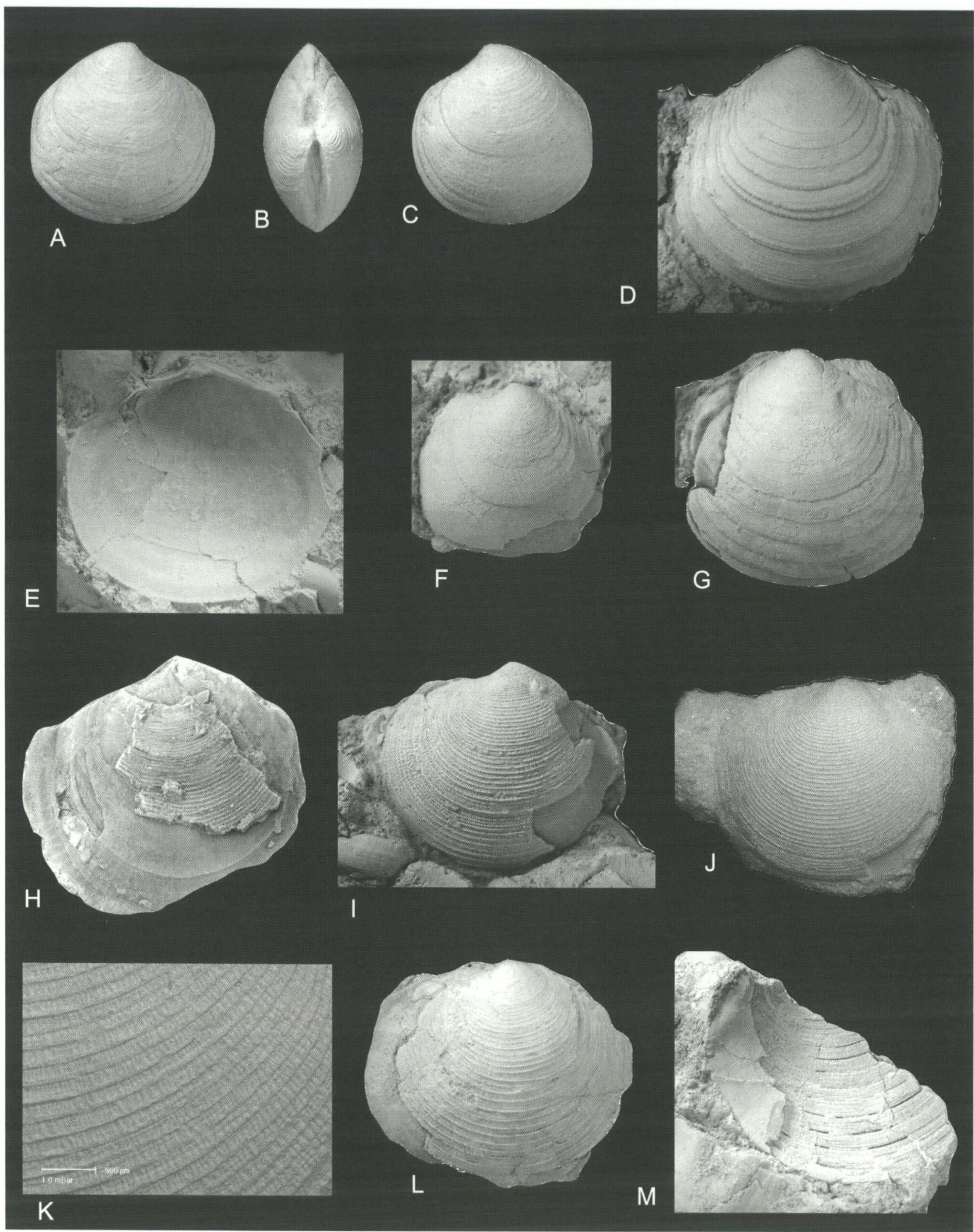

Figure 13 Callucinopsis ? dalmiana sp. nov. ARI G2906/1, holotype, externals of conjoined valves, all x 3, A RV, B dorsal area, C LV. Callucinella marcida sp. nov. D ARI G2782/1, holotype, RV external x 4. E ARI G2782/3, paratype, RV internal x 4. F ARI G2782/5, paratype, LV external x 4. G ARI G2782/6, paratype, RV external x 4. Mesomiltha fallax (Forbes). H NHM 10596, lectotype, fragmentary LV with internal mould, x 2 . Mesomiltha sp. cf. M. fallax (Forbes). I ARI G2781/2, LV external x 4. J ARI G2704/1, LV external x 4.5. K ARI G2704/1, LV enlarged x 12. Mesomiltha? sp. L ARI G2780/16, LV external x 2. M ARI G2780/7, shell fragment and external mould showing commarginal and radial microsculpture $\times 2$. 
faint, irregular, vermiform micro-radials; RV adductor scars - anterior of moderate length, slightly exceeding half shell height and oblique to pallial line; posterior scar larger, roundly subovate; pallial line broad, remote from margin; LV scars obscured; hinge plate narrow, arched; RV tooth $3 \mathrm{~b}$ short, thick; 3a minute, laterals damaged, posterior more distant from cardinals; LV dentition unknown; interior (body cavity) finely radially striate, not punctate; margin without internal crenulae.

Dimensions of Callucinella marcida sp. nov.

\begin{tabular}{|c|c|c|c|}
\hline Specimens & Length & Height & Inflation \\
\hline ARI G2782/1, RV, holotype & 12.0 (est.) & 11.43 & 2.85 \\
\hline ARI G2782/2, RV, paratype & 11.52 & 11.30 & 2.60 \\
\hline ARI G2782/3, RV, paratype & 11.29 & 11.29 & - \\
\hline
\end{tabular}

\section{Remarks}

The fragility of this thin-shelled species makes separation from the rock a matter of chance. No specimen is complete and the internal characters are poorly known. Paratype G2782/3 presents an interior only and, from size and shape, is presumed to be conspecific with the rest of the sample. No specimen shows gastropod predation.

Lamarck's figures of Lucina albella Lamarck, type species of Callucinella Chavan, have been reproduced with publication dates by Palmer (1977: 42 , velin 31 , figs 5,10 ).

\section{Etymology}

Latin marcida (fem.), withered, etc., after the thin, fragile shell.

\section{Occurrence}

Uttattur Group. Odiyam Locality 2. Karai Formation (Odiyam Member). Cenomanian. Uncommon.

\section{Subfamily Myrteinae Chavan, 1969}

\section{Genus Mesomiltha Chavan, 1938}

\section{Type species}

Lucina pulchra Zittel and Goubert, 1861, by original designation. Late Jurassic, France.

\section{Mesomiltha sp. cf. M. fallax (Forbes, 1846)}

Figure $13 \mathrm{H}-\mathrm{K}$

\section{Material examined}

ARI G2704, six LVs, one RV, Locality 1; G2781, six LVs, 10 RVs, Locality 2. Total of 23 single valves, none complete.

\section{Diagnosis}

Medium-sized for genus, suborbicular, slightly produced anteriorly; postero-dorsal area narrow, weakly defined; sculpture of numerous fine, close, commarginal costellae with vermiform, radial microsculpture in interspaces.

\section{Description}

Medium-sized, length to $20 \mathrm{~mm}$, thin, slightly inflated, suborbicular, longer than high, produced anteriorly; postero-dorsal area narrow, weakly defined; umbones broad, slightly elevated, slightly prosogyrate; beaks acuminate, incurved, posterior of centre; lunule short, excavate, on bivalve, RV probably overlapping LV; ligament inframarginal, with small marginal gape; sculpture of numerous fine, close, irregular, commarginal costellae, ca 85 in height of $15 \mathrm{~mm}$, extending to beak; secondary intercostal microsculpture of vermiform radials; adductor scars (from moulds) lightly impressed, often scarcely or not discernible, anterior elongate, descending to about mid-height, curved away from pallial line; posterior scar lozenge-shaped, acuminate below; pallial line broad, entire, distant from margin; margin and interior smooth, latter without punctae or ridges; hinge obscured.

Dimensions of Mesomiltha sp. cf. M. fallax (Forbes, 1846).

\begin{tabular}{lccc}
\hline Specimens & Length & Height & Inflation \\
\hline $\begin{array}{l}\text { NHM 10596, conjoined } \\
\text { pair, lectotype of }\end{array}$ & 25.35 & $21.01^{*}$ & $10.38^{* *}$ \\
$\quad$ Lucina fallax Forbes & & & \\
ARI G2781/1, RV & 18 (est.) & 15.5 (est.) & 5 (est.) \\
ARI G2781/2, LV & 11.7 & 10.5 & 2.8 \\
ARI G2781/3, RV & 20 (est.) & 18 (est.) & 4.4 \\
ARI G2781/4, RV & 15 (est.) & 13.5 (est.) & 3.2 \\
ARI G2781/5, LV & 13 (est.) & 11.6 (est.) & - \\
\hline
\end{tabular}

* incomplete ventrally

** incomplete on RV

\section{Remarks}

The type material of Lucina fallax Forbes, from Pondicherry, collected C.T. Kaye and C.E. Cunliffe, comprises four specimens in the Natural History Museum, London, Geological Society nos 10594, 10595 and 10596 and Geology Dept no. L56539. Examination shows that they represent three species; 10595 and L56539 appear to be conspecific. The precise localisation of this material is undetermined but presumably is either from the Maastrichtian Valudavur or Mettuveli Formations. The largest and best preserved specimen in this material is clearly 10596, conjoined pair, the LV of which is that figured by Forbes (1846) on pl. 17, fig. $8 \mathrm{a}$. Though incomplete, it is the only specimen of the four retaining specific diagnostic characters and is hereby designated lectotype of Lucina fallax Forbes (Fig. 13 H). Specimens 10595, figured by 
Forbes on pl. 17, fig. 8c, and L56539 show some resemblance to Mesomiltha? sp. below. Specimen 10594 (pl. 17, fig. 8b) has no comparable specimen in the study material.

The lectotype of Lucina fallax Forbes is very close to the study material, the latter cited herein however with qualified determination. Forbes' type (10596) is damaged around the lunule and retains sculpture only on the LV median area, where there are 38 commarginal costellae in a height of $10.86 \mathrm{~mm}$. The LV anterior adductor scar is, from the mould, long, narrow and well-separated from the pallial line; posterior adductors faint, higher than long and near the posterior extremity. The RV is extensively decorticated. Forbes' species thus remains poorly defined and further well-localised material from Pondicherry, the type area, is required for this to be clarified. The available characters of the Odiyam material, gleaned from moulds, worn and fragmentary shells, indicate a generic location for this and the following species in Mesomiltha Chavan, based on a Late Jurassic species from Europe (Chavan in Moore 1969: N500, fig. E6-2a, 2b). The present species is distinguished from that which follows by its much finer, more crowded sculpture.

Specimens in the GSI Stoliczka Collection, Kolkata, attributed to "Lucina fallax Forbes" are numbered 1099, 1101, 1102, 1103, 1106, 1108, 1110 and 1111. Except for one (1103 from Ninyoor, Ariyalur Group), all are from or near "Mooraviatoor" and probably derive from the Albian Dalmiapuram Formation. The largest of these, GSI 1108, measures $31.5 \times 29.6 \times 14.2 \mathrm{~mm}$. With two exceptions (GSI 1099 and 1110), the Stoliczka specimens are generally similar to the study material. The two exceptions are astartids and close to the type material of Eriphyla (Miyakoella) badvei sp. nov., described below. GSI 1101 appears also to belong with the Astartidae.

Kauffmann (1973: 369) includes Mesomiltha among his "characteristic, widespread endemic North European" genera, within the North Temperate Realm. The present records would appear to extend that range.

\section{Occurrence}

Uttattur Group. Maruvattur. Dalmiapuram Formation, Albian. Odiyam Localities 1 and 2. Karai Formation (Kunnam and Odiyam Members). Cenomanian. Lectotype of Lucina fallax ForbesAriyalur Group. Pondicherry. Valudavur or Mettuveli Formation. Maastrichtian. "White limestone near Ninnyoor" (Stoliczka 1871: 257). Ninnyur Formation. Paleocene.

\section{Mesomiltha? sp.}

cf. 1846 Lucina fallax Forbes (part.): 143, pl. 17, fig. 8c. Figure $13 \mathrm{~L}, \mathrm{M}$

\section{Material examined}

ARI G2703, eight LVs, 11 RVs and fragments, Locality 1; G2780, $10 \mathrm{LVs}$, one RV, two conjoined pairs, fragments, Locality 2; G2905, three LVs, three RVs, Locality 3 . Total of 38 specimens, none complete.

\section{Description}

Medium sized, length to $25 \mathrm{~mm}$, thin, compressed, suborbicular, slightly longer than high, anteriorly slightly produced, postero-dorsal area slightly depressed, bordered by weak shoulder; umbones broad, slightly inflated and elevated, prosogyrate; beaks acuminate, incurved, almost touching, slightly posterior of centre; lunule of medium length, deep (LV), escutcheon lanceolate (LV); ligamental groove elongate, shallow, above a weak nymph which joins tooth $4 \mathrm{~b}(\mathrm{LV})$; cardinals $(4 \mathrm{~b}, 2)$ fine, divergent; laterals and RV hinge obscured; adductor scars (from moulds) lightly impressed, anterior oblique to pallial line, descending to half or less shell height; posterior adductors broadly elliptical, near postero-dorsal extremity; pallial line broad, entire, well above margin; body cavity faintly striate, not punctate; margin smooth; sculpture of weak, thin, regularly spaced, commarginal lamellae (originally foliaceous but usually worn or broken) with densely crowded vermiform radials in interspaces; decorticated specimens lack sculpture.

Dimensions of Mesomiltha? sp.

\begin{tabular}{lccc}
\hline Specimens & Length & Height & Inflation \\
\hline ARI G2703/1, LV & 16.9 & 15.0 & $2.8^{*}$ \\
ARI G2780/1, LV & 25 (est.) & 22.9 & 5.7 \\
ARI G2780/2, pair & 14 (est.) & 13 (est.) & 5.9 \\
ARI G2780/11, LV & 15.42 & 14.06 & 4.2 \\
\hline
\end{tabular}

* specimen decorticated

\section{Remarks}

The present species resembles and may be related to two specimens at the Natural History Museum, London, part of the type material of Lucina fallax Forbes but specifically distinct from the lectotype of that species, designated above. The specimens are Geological Society no. 10595, that figured by Forbes (1846: 143, pl. 17, fig. 8c) and Geology Dept no. $L 56539$ (unfigured), ex C.T. Kaye and C.E. Cunliffe, juvenile conjoined valves with shell remnants, in pale limestone. The present species appears to be un-named but the specimens are poorly preserved and none is suitable for selection as type. It differs from the preceding species by its much more widely spaced commarginal costellae. There is no evidence of gastropod predation on this species. 


\section{Occurrence}

Uttattur Group. Odiyam Localities 1, 2 and 3. Karai Formation (Odiyam and Kunnam Members). Cenomanian. Forbes' specimens are from the Ariyalur Group of Pondicherry. Maastrichtian.

\section{Genus Paramyrtea gen. nov.}

\section{Type species}

Paramyrtea sabulosa sp. nov.

\section{Diagnosis}

Resembles Myrtea in general form and sculpture, differing in much wider, deeper lunule and presence (RV) of tooth $3 a$ fused to margin of lunule; cardinals robust, laterals equidistant; ligament marginal; anterior adductor scars short, reniform; posterior area weakly defined; internal margin smooth; commarginal costae prominent, lamellose (lamellae rarely preserved).

\section{Remarks}

Differs from Gonimyrtea in greater length relative to height, much shorter anterior adductor scar; stronger, projecting tooth 2 , raised $4 \mathrm{~b}$, presence of $3 a$, stronger $3 \mathrm{~b}$ and well developed laterals on both valves. Differs from Mesomiltha in greater relative length, shorter, wider lunule, shorter anterior adductor scar, paired cardinals in each valve and stronger, equidistant laterals. Differs from both Mesolinga and Cavilinga in presence of cardinal 3a and shorter anterior adductor scar.

\section{Paramyrtea sabulosa sp. nov.} Figures $14 \mathrm{~A}-\mathrm{F}, 15 \mathrm{~A}-\mathrm{F}$

\section{Material examined}

\section{Holotype}

ARI G2702/1, RV, from greyish-brown, ammonite-rich, quartzose calcarenite ca $1.2 \mathrm{~km} \mathrm{~W}$ of Odiyam village, Perambalur Taluk, Tiruchirapalli district, Tamil Nadu (Locality 1).

\section{Paratypes}

ARI G2702/2-53, six conjoined pairs, $22 \mathrm{LVs}, 24$ RVs, Locality 1 . Total of 53 specimens.

\section{Other material}

ARI G2702, 368 single valves, all juvenile and incomplete, Locality 1; G2779, 11 single valves, Locality 2; G2904, 13 single valves, Locality 3. Total of 416 single valves (plus type material).

\section{Diagnosis}

As for genus.

\section{Description}

Medium sized, length to $13 \mathrm{~mm}$, robust, compressed, roundly subrectangular, longer than high, slightly produced anteriorly; umbones broad, slightly (juvenile) to moderately (mature) inflated, slightly elevated, prosogyrate; beaks acuminate, incurved, almost touching, prosogyrate; lunule and escutcheon well defined, smooth, RV overlapping LV; lunule broad, excavate; escutcheon lanceolate, narrower and longer than lunule; ligament marginal, externally visible, short; antero-dorsal margin concave; postero-dorsal margin oblique, almost straight, meeting truncate posterior margin at angulation; anterior and ventral margins evenly rounded, latter smooth within; posterior area defined by weak shoulder; cardinal dentition - (RV) $3 a$ and $3 b$ present, former thin, oblique, fused to lunular margin, latter thick, oblique, triangular (LV) 2 and $4 \mathrm{~b}$ present, former triangular, thick, latter thin, oblique; laterals equidistant, remote, double on $\mathrm{RV}$, single on $\mathrm{LV}$; adductor scars impressed, located immediately below lateral teeth, anterior short, higher than long with short lobe detached from pallial line; posterior scar smaller, subrectangular; pallial line entire, well above margin; body cavity very slightly or not punctate or with obscure radial marks. Sculpture of strong, close, commarginal costae, usually narrower than interspaces, about 30 in height of $11 \mathrm{~mm}$ (holotype), costae lamellose on crests but usually broken off either before or during extraction; intercostal spaces with very fine, commarginal striae and occasional faint to obscure vermiform radials.

Dimensions of Paramyrtea sabulosa gen. nov., sp. nov.

\begin{tabular}{lccc}
\hline Specimens & Length & Height & Inflation \\
\hline $\begin{array}{c}\text { ARI G2702/1, } \\
\text { holotype, RV }\end{array}$ & 13.16 & 10.78 & 3.10 \\
$\begin{array}{c}\text { ARI G2702/2, } \\
\quad \text { paratype, RV }\end{array}$ & 9.71 & 8.52 & - \\
$\begin{array}{c}\text { ARI G2702/4, } \\
\text { paratype, RV }\end{array}$ & 12.1 (est.) & 10.7 (est.) & 3.3 (est.) \\
$\begin{array}{c}\text { ARI G2702/5, } \\
\text { paratype, LV }\end{array}$ & 12.8 (est.) & 10.6 (est.) & 3.2 (est.) \\
\hline
\end{tabular}

\section{Remarks}

The present species is common in the shelly limestones of the Karai Formation at Odiyam, notably at Locality 1 , where it is by far the most abundant bivalve. One may note a degree of similarity between this species and some of the figures of "Lucina fallax Forbes" in Stoliczka (1871, pl. 13, figs $13,15-17$, pl. 14, figs $3,5,7,8$ ) based on specimens mostly from the Uttattur Group at Maruvattur. However, the lectotype of Lucina fallax Forbes, designated above, differs substantially from the present species in its suborbicular outline, greater size, finer sculpture (38 commarginal 


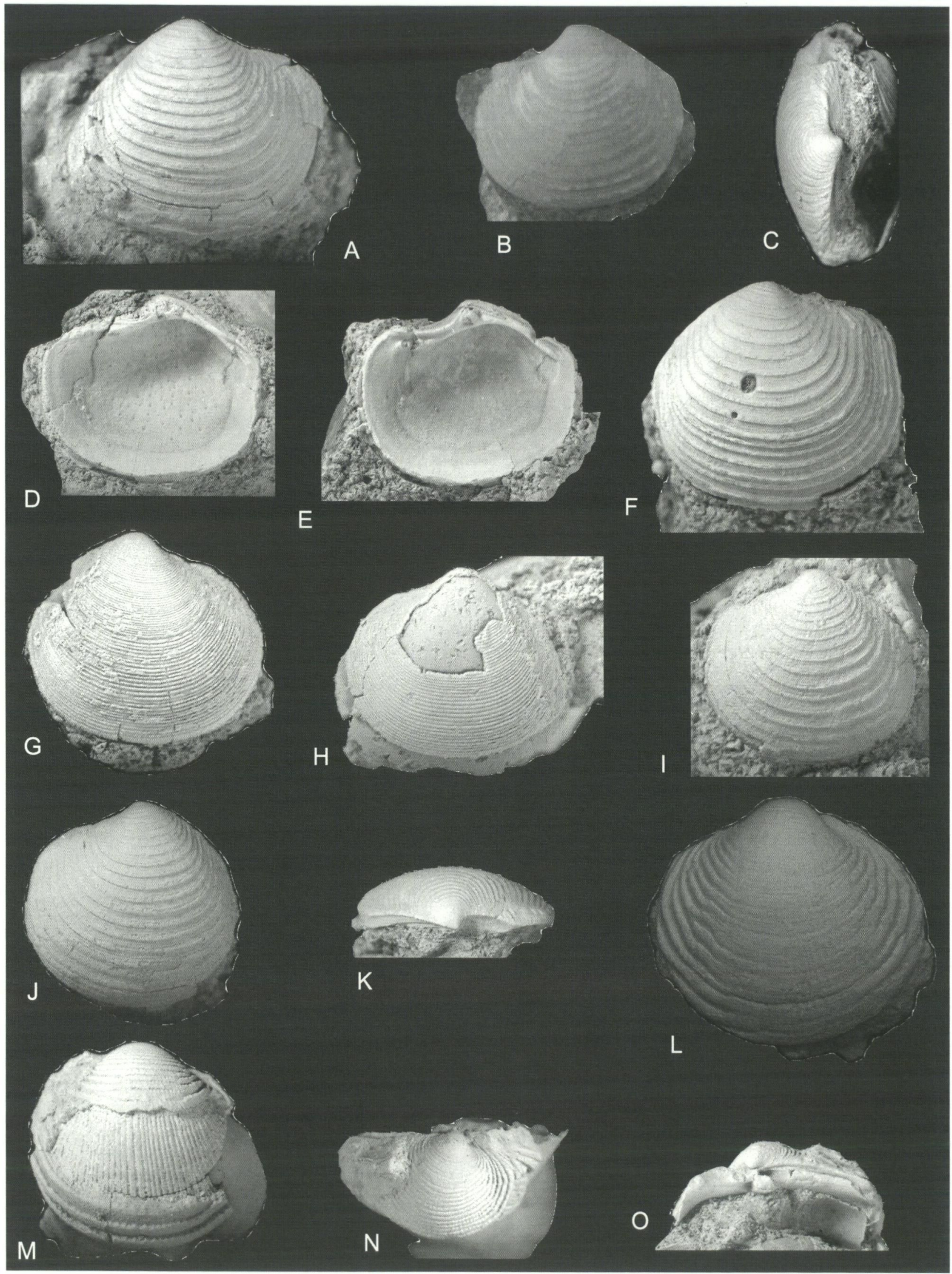

Figure 14 Paramyrtea sabulosa gen. nov., sp. nov. A ARI G2702/1, holotype, RV external x 4. B ARI G2702/10, paratype, LV external x 6. C ARI G2702/7, paratype, LV dorsal aspect x 4. D ARI G2702/2, paratype, RV with pitted internal surface $\times 4$. E ARI G2702/8, paratype, RV internal x 6. F ARI G2702/6, paratype, RV external with two probable gastropod boreholes x 6. Lucinid sp. A. G ARI G2707/2, RV external x 6. H ARI G2707/1, LV external x 6. Lucinid sp. B. I ARI G2923/1, LV external x 4. J, K ARI G2923/2, LV external and dorsal aspects x 4. Fimbria sp. L ARI G2784/2, juvenile LV, external x 7.5. M, N, O ARI G2705, RV. M external, partly decorticated. $\mathbf{N}$ umbonal area. $\mathbf{O}$ hinge and internal dorsal margin. 


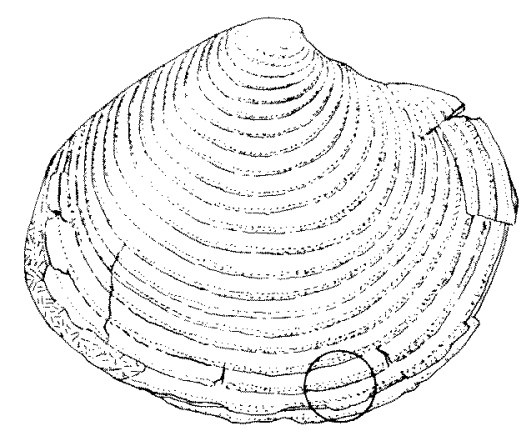

A

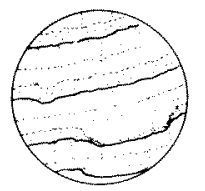

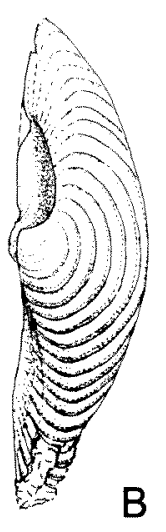

B
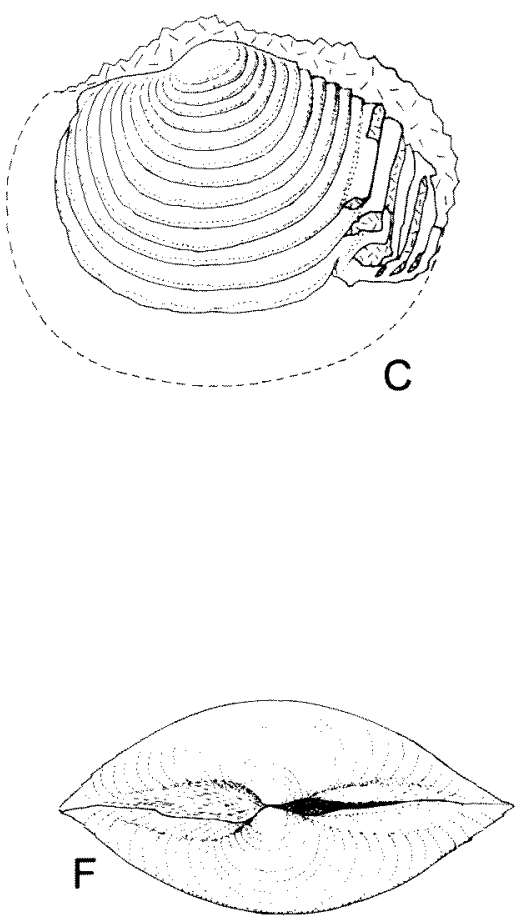

E

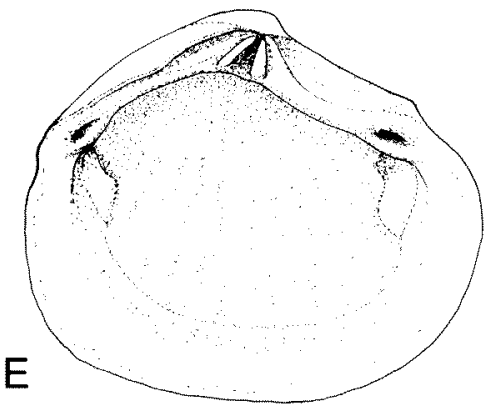

Figure 15 Paramyrtea sabulosa gen. nov., sp. nov. A ARI G2702/1, holotype, RV external x 3.8 with further enlargement of sculpture. B ARI G2702/1, holotype, RV dorsal aspect x 3.8. C ARI G2702/20, paratype, LV external x 5.5. D ARI G2702, composite internal RV x 5. E ARI G2702, composite internal LV x 3.4. F ARI G2702, composite dorsal aspect, conjoined valves.

costellae in height of $10.86 \mathrm{~mm}$ ) and its long anterior adductor scar. Stoliczka's "Lucina fallax Forbes" material, some poorly preserved, comprises an assortment of lucinid and astartid taxa. Provisional determinations for some of these are noted elsewhere in this paper.

The present species somewhat resembles "Lucina" canterburiensis Woods from the Campanian Amuri Group of New Zealand, differing in its much larger lunule and less-defined postero-dorsal area (Woods 1917: 30, pl. 16, figs 4, 5). From "Lucina (Myrtea)" arcotina Stoliczka and from "Lucina (Myrtea)" dentigera Stoliczka, it differs in outline and sculpture (Stoliczka 1871). In shape, it resembles Lucina tenera (J. Sowerby) from the Albian of southern England, differing in its stronger, more spaced ribs and weaker posterior area; from Lucina downesi Woods (Albian, southern England), differing by fewer more spaced ribs, more elevated umbone, broader lunule and smaller size (Woods 1907: 154, 155, pl. 24, figs 10-15).

Extraction of specimens of the present species from the hard matrix, especially from the type locality, invariably breaks some part of the shell. Separation usually occurs along the convex outer surface, removing the lamellose rib crests. Internal surfaces and characters, including hinges, are known only from a few specimens in the paratype series. Of the 445 specimens to hand, all but six being single valves, 58 show one or more gastropod boreholes, a predation rate of $13 \%$. Most boreholes are infilled but some are clearly of the bevelled or countersunk type attributed to naticid snails (Kabat 1990). Other boreholes, mostly narrow, appear to lack bevelling.

\section{Etymology}

Latin sabulosa (f.), full of sand, sandy, from the lithofacies, notably of the type locality, where the species is very common.

\section{Occurrence}

Uttattur Group. Odiyam Localities 1 (type), 2 and 3. Karai Formation (Odiyam and Kunnam Members). Cenomanian. 
Lucinid, genus and species undetermined, Species A

Figure $14 \mathrm{G}, \mathrm{H}$

\section{Material examined}

ARI G2707, one LV, one RV, Locality 1; G2907, one LV, Locality 3 . Total of three single valves.

\section{Description}

Small, length to $8 \mathrm{~mm}$, thin-shelled, subovate, longer than high, anteriorly extended, posteriorly subtruncate; umbones slightly inflated, elevated, prosogyrate; beak acuminate, incurved, prosogyrate; lunule lanceolate, shallow; escutcheon narrow; ligament marginal; areas weakly defined; sculpture of very fine, close, regular commarginal costellae, about as wide as interspaces, becoming obsolete toward flanks; no radials; margin finely crenulate internally; other internal characters obscured.

Dimensions of lucinid species A.

\begin{tabular}{lccc}
\hline Specimens & Length & Height & Inflation \\
\hline ARI G2707/1, LV & 6.47 & 6.1 (est.) & 1.4 \\
ARI G2707/2, RV & 6.90 & 6.34 & 1.35 \\
ARI G2907, LV & 8.4 (est.) & 8.24 & - \\
\hline
\end{tabular}

\section{Remarks}

The very fine, close, regular sculpture, extending to the beak and the shallow lunule, distinguish this species from all other lucinids in the study material. An affinity with the genus Myrtea Turton seems possible but cannot be established without the internal characters, at present unknown.

\section{Occurrence}

Uttattur Group. Odiyam Localities 1 and 3. Karai Formation (Kunnam Member). Cenomanian. Rare.

\section{Lucinid, genus undetermined, Species B} Figure $14 \mathrm{I}-\mathrm{K}$

\section{Material examined \\ ARI G2923, six LVs and two RVs, Locality 3.}

\section{Description}

Small, to $10 \mathrm{~mm}$ in length, robust, roundly subovate, slightly longer than high, with sub-median, elevated, gently inflated umbones; areas weakly developed, posterior larger and better defined; beak sub-median, incurved, prosogyrate; antero-dorsal margin slightly concave; postero-dorsal margin slightly convex; anterior and posterior margins slightly truncate; ventral margin evenly rounded; lunule short, excavate, with weak radial groove (LV); escutcheon narrowly lanceolate, deep; ligament marginal, extending two thirds of postero- dorsal margin, on strong nymph. Dentition: LV cardinal 2 strong, triangular, bifid, vertical; $4 \mathrm{~b}$ narrow, slightly oblique, triangular; other cardinals concealed; LV lateral AII, a deep socket with strong tooth on ventral side, probably closer to cardinals than concealed posterior lateral; RV laterals obscured. Anterior adductor scar (LV) faintly impressed (G2923/5), of moderate width, descending to ca half height of shell, parallel and close to pallial line; margin internally smooth, bevelled outside pallial line. Sculpture commarginal only, of narrow costellae with broad interspaces, ca 26 in height of $8.3 \mathrm{~mm}$, extending to beak; very fine micro-striae present between costellae.

Dimensions of lucinid, genus undetermined, Species B.

\begin{tabular}{lccc}
\hline Specimens & Length & Height & Inflation \\
\hline ARI G2923/1, LV & 9.45 & 8.48 & 1.7 (est.) \\
ARI G2923/2, LV & 9.76 & 9.60 & 2.0 (est.) \\
\hline
\end{tabular}

\section{Remarks}

The generic location of this rare species remains unclear and subject to the collection of further material. The smooth margin distinguishes it from both Callucinopsis Chavan and Cavilinga Chavan and it lacks the globosity and anterior extension of Mesolinga Chavan. Because of hard matrix, internal characters, notably of the hinge, are uncertain; the anterior adductor scar was observed by temporarily lifting the much-cracked G2923/5 away from the matrix, to which it has been rejoined subsequently.

\section{Occurrence}

Uttattur Group. Odiyam Locality 3. Karai Formation (Kunnam Member). Cenomanian. Rare.

\section{Family Fimbriidae Nicol, 1950}

\section{Genus Fimbria Mergerle von Mühlfeld, 1811}

Corbis Cuvier, 1817

\section{Type species}

Fimbria magna Mergerle von Mühlfeld, 1811 (junior synonym of Venus fimbriata Linnaeus, 1758), by original designation. Recent, Indo-Pacific.

\section{Fimbria sp. \\ Figure $14 \mathrm{~L}-\mathrm{O}$}

\section{Material examined}

ARI G2705, one RV, Locality 1; G2784, one LV, one RV, Locality 2 . Total of three juvenile valves.

\section{Description}

Small, length to $16 \mathrm{~mm}$, apparently juvenile, 
robust, subequilateral, ovate, slightly longer than high; umbones inflated, prominent, moderately elevated; beaks incurved, prosogyrate; anterodorsal margin short, effuse; postero-dorsal margin longer; ligament marginal, arched above low nymph; sculpture of close, irregular, wrinkled, commarginal costae, ca 30 in height of $11.5 \mathrm{~mm}$, fewer on flanks; fine, close, secondary radials cross costae, mainly on dorsal side and in interspaces; radials obsolete on anterior flank; middle shell layer with well-developed internal radial costae, visible on decorticated surface and along broken margin; beaks $(1.7 \mathrm{~mm})$ more or less smooth; RV cardinal tooth $3 \mathrm{~b}$ massive; laterals present on both valves, small, anterior much closer than posterior; margin finely crenulate; other internal characters unknown.

Dimensions of Fimbria sp.

\begin{tabular}{lccc}
\hline Specimens & Length & Height & Inflation \\
\hline ARI G2705, RV & 15 (est.) & 15 (est.) & 7.5 (est.) \\
ARI G2784/1, LV & 16 (est.) & 16 (est.) & 5.8 \\
ARI G2784/2, RV & 6.6 & 6.4 & 2.4 \\
\hline
\end{tabular}

\section{Remarks}

This appears to be the first confirmed record of Fimbria from the Cretaceous of south India. Stoliczka's (1871: 254, 255, pl. 13, figs 10-12) species "Corbis" typica and " $C$." oblonga were described from the Ariyalur Group of "Ninnyoor", now assigned to the Paleocene (Danian) Ninnyur Formation (Sundaram et al. 2001: 755). These are still assumed incorrectly to be Cretaceous records (e.g., Monari 2003: 863). The Odiyam specimens are closer to Fimbria typica (Stoliczka), differing in the much reduced anterior radial sculpture. Though new, the limited material to hand from Odiyam is inadequate for full description and type selection. Fimbria is among the Cretaceous genera "typical of the Indo-Pacific [region] but with limited outside distribution..." according to Kauffmann (1973: 373).

\section{Occurrence}

Uttattur Group. Odiyam Localities 1 and 2. Karai Formation (Kunnam and Odiyam Members). Cenomanian. Rare.

\section{Superfamily Crassatelloidea Férussac, 1822}

Family Crassatellidae Férussac, 1822

\section{Subfamily Crassatellinae Férussac, 1822}

\section{Genus Anthonya Gabb, 1864}

\section{Type species}

Anthonya cultriformis Gabb, 1864, by monotypy. Late Cretaceous, California.

\section{Anthonya sp.}

Figure 16A, B

\section{Material examined}

ARI G2788, five LVs, Locality 2; G2912, three LVs, Locality 3 . Total of eight single valves.

\section{Description}

Medium-sized for genus, length to $60 \mathrm{~mm}$, robust, strongly compressed and inequilateral; anterior roundly truncate; posterior extended, tapering; umbones broad, orthogyrate; postero-dorsal area narrowly elongate, defined by rounded shoulder; lunule narrow, shallow, bordering hinge plate; escutcheon obscured; anterior margin short, oblique, slightly convex, rounding into long, broadly convex ventral margin; posterior margin short, truncate; postero-dorsal margin long, slightly concave; sculpture of fine, close, rounded, irregular, commarginal costellae, obsolete on postero-dorsal area; hinge plate broad in cardinal area, narrowing posteriorly; hinge (LV only), two oblique, slightly divergent cardinals; $4 \mathrm{~b}$ narrow, tapering; 2 broader, serrated on anterior side; posterior lateral extended, submarginal; resilium long, oblique, shallow, submarginal; anterior adductor scar ovate, well impressed, below end of hinge plate; posterior scar larger, ovate, lightly impressed, mostly posterior of lateral tooth; margin smooth.

Dimensions of Anthonya sp.

\begin{tabular}{lccc}
\hline Specimens & Length & Height & Inflation \\
\hline ARI G2788/1, LV & 60 (est.) & 23 (est.) & - \\
ARI G2788/2, LV & 19 (est.) & 9 (est.) & - \\
\hline
\end{tabular}

\section{Remarks}

The genus Anthonya has been reviewed by Hayami (1965b), citing occurrences in N America, Western Europe, South Africa, New Zealand and Japan; to these we now add south India. Though larger, the present species resembles in outline $A$. cantiana Woods from the Albian Lower Greensand - Gault of England (Woods 1906: 130, 131, pl. 19, figs 4, 5) and also $A$. subcantiana Nagao from the Aptian-Albian of northern Honshu (Hayami 1965b), differing from both by the more or less smooth postero-dorsal area and finer commarginal ribbing. Though of comparable size, the Odiyam species is much more finely ribbed than A. elongata Woods from the Campanian Amuri Group of New Zealand (Woods 1917). Only LVs, fragmentary or juvenile, are at present available and a full description of the present species awaits the collection of further material.

\section{Occurrence}

Uttattur Group. Odiyam Localities 2 and 3. Karai Formation (Odiyam and Kunnam Members). Cenomanian. Rare. 


\section{Family Astartidae d'Orbigny, 1844}

\section{Subfamily Astartinae d'Orbigny, 1844}

\section{Genus Goodallia Turton, 1822}

\section{Type species}

Mactra triangularis Montagu, 1803, by subsequent designation of Hermannsen 1847. Recent, N Atlantic.

\section{Goodallia salebrosa sp. nov.} Figure $16 \mathrm{C}-\mathrm{E}$

\section{Material examined}

\section{Holotype}

ARI G2785/1, conjoined pair, from brown calcareous siltstone with abundant turritellid gastropods, beside track ca $0.5 \mathrm{~km}$ west of Odiyam village, Perambalur Taluk, Tiruchirapalli district, Tamil Nadu (Locality 2).

\section{Paratypes}

ARI G2785/2-19, five LVs, two RVs, 11 conjoined pairs, from the type locality. Total of 19 specimens.

\section{Other material}

ARI G2706, three LVs, five conjoined pairs, Locality 1. Total of eight specimens (plus type material).

\section{Diagnosis}

Small for genus (i.e., minute), length to $2 \mathrm{~mm}$, subtrigonal, roundly triangular; lunule minute, escutcheon lanceolate, well defined; sculpture, except on beaks, obsolete, reduced to row of spaced plicae along postero-dorsal margins; ventral margin crenulate.

\section{Description}

Minute, robust, roundly triangular, slightly longer than high; umbones inflated, slightly prosogyrate; beaks incurved, prosogyrate, anterior of midline; lunule broad, shallow; escutcheon lanceolate, well defined, LV overlapping RV, occupying entire postero-dorsal margin; ligament internal, submarginal; antero-dorsal margin oblique, almost straight; postero-dorsal margin about as long, oblique, slightly convex; extremities and ventral margin rounded, latter broadly; prodissoconch I smooth; prodissoconch II $(0.2 \mathrm{~mm})$ with close, commarginal costellae, distinct from teleoconch; elsewhere, exterior smooth, polished, except for row of spacèd plicae along postero-dorsal margin; LV with two divergent cardinals, $4 \mathrm{~b}$ short, thick; 2 small, short; laterals apparently absent; adductor scars large, moderately impressed, located above anterior and posterior extremities (from moulds); margin (excluding antero-dorsal and posterodorsal) crenulate internally.

Dimensions of Goodallia salebrosa sp. nov.

\begin{tabular}{lccc}
\hline Specimens & Length & Height & Inflation \\
\hline $\begin{array}{c}\text { ARI G2785/1, conjoined } \\
\text { pair, holotype }\end{array}$ & 1.57 & 1.48 & 0.96 \\
$\begin{array}{c}\text { ARI G2785/2, conjoined } \\
\text { pair, paratype }\end{array}$ & 1.98 & 1.73 & 1.02 \\
\hline
\end{tabular}

\section{Remarks}

The affinities of this small, distinctive astartid appear to lie with the genus Goodallia Turton, though well outside the time range of that genus $s$. str., Miocene-Recent according to Chavan (in Moore 1969: N566). The internal (submarginal) ligament distinguishes the present species from the living forms of Goodallia (Giribet and Peñas 1999). Erection of a new subgenus or genus to accommodate this and the following species may prove desirable but this is deferred until more is known of the RV hinge. Differs from $G$. ? australindica sp. nov. by its smaller size, roundly triangular profile and obsolete sculpture. Variation in the species concerns the prominence or otherwise of the row of plicae along the posterodorsal margin. These appear to be remnants of a once more extensive commarginal ribbing. This, the smallest species in the study material, is of comparable size to those of some modern $\mathrm{N}$ Atlantic-Mediterranean species of Goodallia described by Giribet and Peñas (1999). Goodallia is among the genera characteristic of the Euramerican region, North Temperate Realm, according to Kauffmann (1973: 368). This is the first record from the Indian Cretaceous.

\section{Etymology}

From the Latin salebrosa (fem.), roughness of a track, pertaining to the type locality.

\section{Occurrence}

Uttattur Group. Odiyam Localities 1 and 2 (type). Karai Formation (Odiyam and Kunnam Members). Cenomanian. Rare.

\section{Goodallia ? australindica sp. nov. Figure 16 F, G}

\section{Material examined}

\section{Holotype}

ARI G2910/1, RV, from hard, greyish-brown, quartzose, limestone with abundant Trigonarca by nullah $c a 1.0 \mathrm{~km}$ south of Odiyam village, Perambalur Taluk, Tiruchirapalli district, Tamil Nadu (Locality 3). 


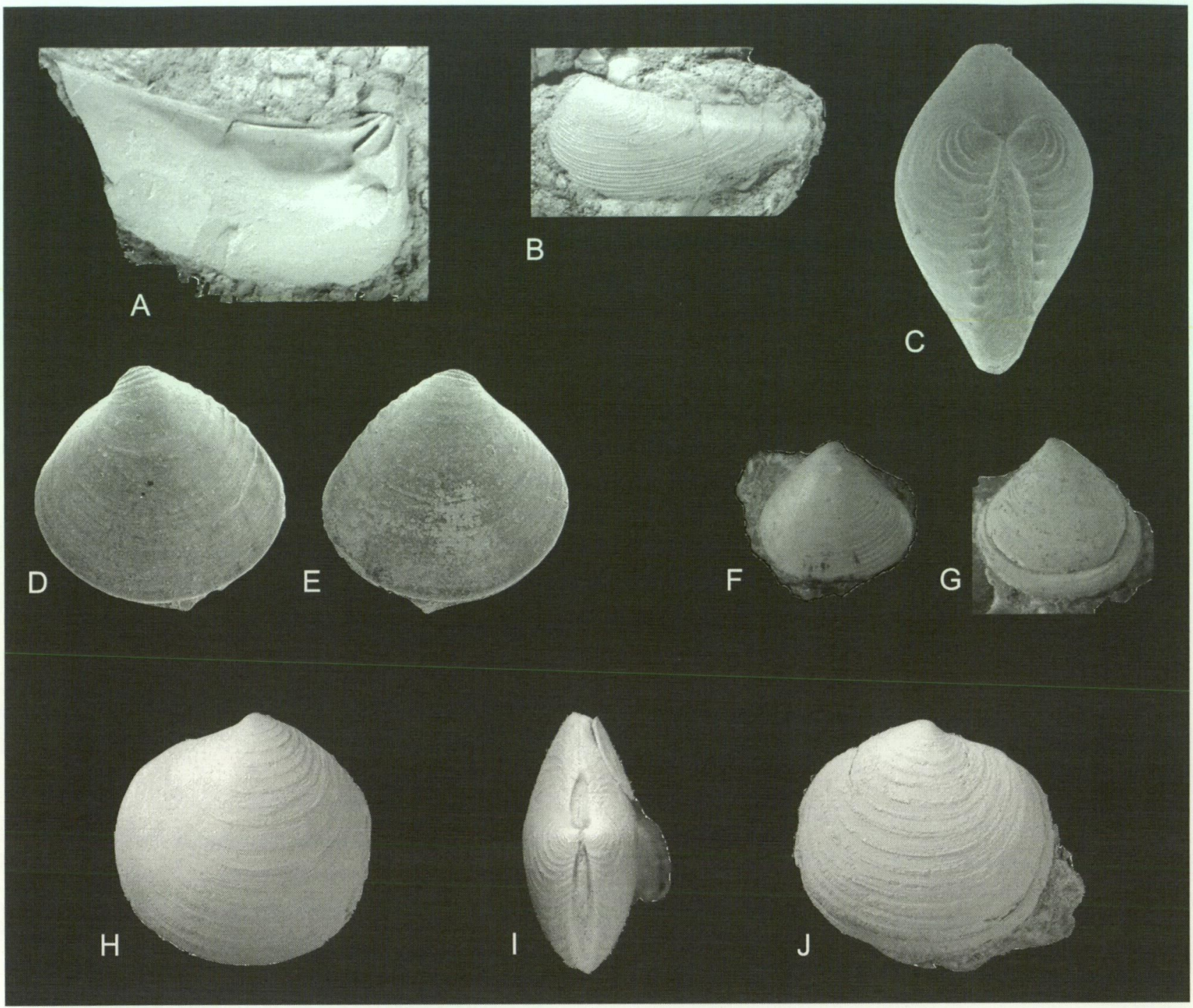

Figure 16 Anthonya sp. A ARI G2788/1, LV internal x 1.5. B ARI G2788/2, LV external x 2.0. Goodallia salebrosa sp. nov. C ARI G2785/1, holotype, conjoined pair, dorsal aspect x 25 C dorsal. D same, RV x 25. E same, LV x 25. Goodallia ? australindica sp. nov. F ARI G2910/1, holotype, RV x 38. G ARI G2910/2, paratype, LV x 4.2. Eriphyla (Miyakoella) badvei sp. nov. H ARI G2783/1, holotype, LV of conjoined pair x 2. I same, dorsal aspect x 2. J ARI G2783/3, paratype, RV x 2 .

\section{Paratypes}

ARI G2910/2-8, five LVs, two RVs, from the type locality. Total of eight single valves.

\section{Other material}

ARI G2910/9-16, eight valves, Locality 3; G2840, one LV, Locality 2; G2841, one RV, Locality 2. Total of 10 single valves (plus type material).

\section{Diagnosis}

Large for genus, triangular, subtrigonal; anteroand postero-dorsal margins almost straight, subtending angle of ca $90^{\circ}$; lunule and escutcheon extended, weakly defined; smooth or with fine commarginal costellae on anterior third and ventrally; margin crenulate. Differs from Goodallia salebrosa Kendrick and Vartak in more triangular outline, stronger sculpture and greater size.

\section{Description}

Small (large for genus), robust, subtrigonal, equilateral, height and length approximate; umbones slightly inflated, orthogyrate, elevated; beak acuminate, incurved, prosogyrate; antero- and postero-dorsal margins almost straight, subtending angle of ca $90^{\circ}$; plane of maximum length in lower half; ligament obscured, apparently internal; lunule and escutcheon shallow, extended, weakly defined; sculpture usually of fine, close, astartiform, commarginal costellae, mainly on anterior third and ventral area; occasional shells smooth; prodissoconch I smooth, followed by $0.3 \mathrm{~mm}$ of fine, close, astartiform, commarginal costellae, 
subsequently smooth; worn shells show weak internal radial rib structure on outer surface; strong growth-pause lines sometimes present; ventral margin internally crenulate; hinge and other internal characters obscured.

Dimensions of Goodallia? australindica sp. nov.

\begin{tabular}{lccc}
\hline Specimens & Length & Height & Inflation \\
\hline ARI G2910/1, RV, holotype & 5.52 & 5.33 & 1.4 \\
ARI G2910/2, LV, paratype & 5.51 & 5.52 & 1.5 \\
\hline
\end{tabular}

\section{Remarks}

The generic location of this small astartid remains subject to confirmation until the hinge details, in particular, become available. It differs from Goodallia triangularis (Montagu) in its less oblique, distinctly triangular outline and from "Astarte" pumilla J. de C. Sowerby, Bathonian of England and type species of the genus or subgenus Ancliffia Cox and Arkell, in its lower apex and more triangular outline. As with the preceding species, the ligament is not external, a point of difference from the extant species of Goodallia (Giribet and Peñas 1999).

\section{Etymology}

From the Latin australis, southern and indica (fem.), of India.

\section{Occurrence}

Uttattur Group. Odiyam Localities 2 and 3 (type). Karai Formation (Odiyam and Kunnam Members). Cenomanian. Uncommon.

\section{Subfamily Eriphylinae Chavan, 1952}

\section{Genus Eriphyla Gabb, 1867}

\section{Type species}

Eriphyla umbonata Gabb, 1867 , by original designation. Late Cretaceous, California.

\section{Subgenus Miyakoella Hayami, 1965}

\section{Type species}

Astarte miyakoensis Nagao in Yabe, 1927, by original designation. Aptian-Albian, northern Japan.

\section{Remarks}

The subgenus has been established (Hayami 1965b) for species of Eriphyla combining a smooth or lightly sculptured exterior with a finely crenulated inner ventral margin; differs from Dozyia Bosquet in Dewalque in outline and presence of marginal crenulae. Beside the type species from the Aptian-Albian of northern Japan, the subgenus occurs in the Neocomian of East Africa and Argentina and Late Jurassic of England (Hayami 1965b).

\section{Eriphyla (Miyakoella) badvei sp. nov.} Figure $16 \mathrm{H}-\mathrm{J}$

1871 Lucina fallax Forbes (part.); Stoliczka: 256, 257, pl. 13 , figs $13,13 a$.

\section{Material examined}

\section{Holotype}

ARI G2783/1, conjoined pair, from brown calcareous siltstone with abundant turritellid gastropods, beside track ca $0.5 \mathrm{~km}$ west of Odiyam village, Perambalur Taluk, Tiruchirapalli district, Tamil Nadu (Locality 2).

\section{Paratypes}

ARI G2783/2-8, two conjoined pairs, three LVs, two RVs, from the type locality. Total of eight specimens.

\section{Diagnosis}

Suborbicular, lenticular; umbones slightly elevated; beak slightly posterior of centre; sculpture of near-obsolete, spaced, commarginal ridges, concentrated on beaks as fine costellae; posterior area small; margin finely crenulate.

\section{Description}

Medium-sized for genus and subgenus, robust, suborbicular, lenticular, slightly longer than high, extended anteriorly, subtruncate posteriorly; posterior area small, weakly differentiated; anterodorsal margin slightly concave; postero-dorsal margin slightly convex; umbones broad, slightly elevated; beaks acuminate, incurved, almost touching, prosogyrate, slightly posterior of centre; lunule medium-sized, shallow, asymmetrical, RV overlapping LV; escutcheon extended, lanceolate; ligament external, on some specimens well preserved; sculpture subdued, of low, spaced, commarginal ridges, ca 22 in height of $18 \mathrm{~mm}$,

Dimensions of Eriphyla (Miyakoella) badvei sp. nov.

\begin{tabular}{lccc}
\hline Specimens & Length & Height & Inflation \\
\hline ARI G2783/1, conjoined pair, 18.42 & 18.18 & 8.12 \\
$\quad$ holotype & & & \\
ARI G2783/2, conjoined pair, 16.74 & 15.36 & $8.05^{*}$ \\
$\quad$ paratype & & & \\
ARI G2783/3, RV, paratype & 18.14 & 16.80 & 4.29 \\
ARI G2783/4, RV, paratype & 16.69 & 16.48 & 3.82 \\
ARI G2783/5, LV, paratype & 18.46 & 17.37 & 4.26 \\
ARI G2783/6, LV, paratype & 18.00 & 17.98 & 4.32 \\
\hline
\end{tabular}

${ }^{*}$ ventral gape of ca $0.8 \mathrm{~mm}$ 
intensified as fine costellae around beaks; interspaces with very fine, crowded, commarginal micro-striae; cardinals obscured; RV laterals equidistant from cardinals, A1 and P1 short, stout; LV laterals obscured; adductor scars unknown; margin with fine internal crenulae; strong, stepped, growth-pause lines sometimes present.

\section{Remarks}

Differs from Eriphyla (Miyakoella) miyakoensis in less elevated umbones and stronger sculpture; from "Lucina" jugosa Forbes by anterior extension and posterior truncation, weaker sculpture and longer, shallower lunule; from "Lucina" fallax Forbes (lectotype designated above), differs in less inflated shell, fewer, stronger commarginal costellae, prominent external ligament and crenulate margin.

The study material closely resembles and is probably conspecific with GSI Stoliczka Collection 1099 and 1110, which are part of the series assigned by Stoliczka (1871: 256, 257) to "Lucina fallax Forbes" (see above). The former is that figured on his Plate 13, figs 13, 13a. This specimen, from "Mooraviatoor, Uttatur Group" [=Maruvattur], comprises conjoined valves measuring $\mathrm{L} 17.96, \mathrm{Ht}$ 17.08, Inf. $10.34 \mathrm{~mm}$; valves thickened ventrally, apparently gerontic; worn dorsally - better preserved RV retains traces of astartid sculpture on beak; margin finely crenulate. The source of these specimens may lie within the calcareous upper unit of the Dalmiapuram Formation (Albian).

\section{Etymology}

After Dr Ramesh M. Badve, in appreciation of his contributions to the Cretaceous palaeontology of south India and of his encouragement and generous support for this study whilst Head, Department of Geology and Palaeontology, Agharkar Research Institute, Pune.

\section{Occurrence}

Uttattur Group. Odiyam Locality 2. Karai Formation (Odiyam Member). Cenomanian. Rare. Maruvattur. Dalmiapuram Formation. Late Albian.

\section{Superfamily Cardioidea Lamarck, 1809 \\ Family Cardiidae Lamarck, 1809 \\ Subfamily Protocardiinae Keen, 1951}

\section{Diagnosis}

The subfamily has been re-defined by Keen (1980: 12) as follows: "Shell rounded-quadrate in outline, nearly equilateral; radial ribs present in most; posterior slope usually more strongly ribbed than remainder of shell, ribs often spinose; ribs of central and anterior slopes, when present, fine and numerous; hinge line long, nearly straight to somewhat arched; cardinal teeth, especially anterior cardinals, well developed; anterior laterals strong (rarely wanting)".

From a study of cardiid and related shell microstructure, Schneider and Carter (2001: 631633) favoured Jurassic-Cretaceous Protocardia as representing "the ancestral stock for later cardiids".

\section{Genus Protocardia von Beyrich, 1845}

\section{Type species}

Cardium hillanum Sowerby, 1813, by subsequent designation of Herrmannsen 1847. AlbianCenomanian, England.

\section{Subgenus Protocardia s. str}

\section{Protocardia (Protocardia) alta (Sowerby in Forbes, 1846) \\ Figure $17 \mathrm{~A}-\mathrm{D}$}

1846 Cardium altum Sowerby in Forbes: 145, pl. 15, figs $13 a-c$ (ex G.B. Sowerby MSS).

1870 Protocardium altum (Sowerby); Stoliczka: 221, pl. 12, figs 1,3 .

1979 Protocardia (P.) alta (Sowerby); Chiplonkar and Tapaswi: 138, 156.

\section{Material examined}

GSI Stoliczka Collection 1076, one RV, "Monglepaudy". ARI G2914, one LV, three RVs, Locality 3.

\section{Diagnosis}

Large, height to $67 \mathrm{~mm}$, robust Protocardia s. str., higher than long; anterior flank and umbones smooth; median area with low commarginal costae; posterior flank with fine radials; hinge arched, teeth massive.

\section{Description}

Large, robust, thick, higher than long, obliquely subovate, subtrigonal; umbones tumid, elevated, prosogyrate; beaks incurved, proximate, touching nymph, slightly posterior of midline; posterior area well defined, bordered by weakly angulate shoulder; dorsal margin arched, short posteriorly; anterior margin oblique, strongly rounded at extremity, thence merging into broadly rounded, oblique ventral margin; posterior margin long, subtruncate, meeting ventral margin at rounded angle; anterior flank and umbo more or less smooth; posterior area with low, crowded radial costellae, abruptly terminated at shoulder; median area with low commarginal corrugations; growth ridges present on older parts of some valves; hinge plate broad, arched; 
cardinals broken, 3b large, erect; anterior laterals distant from cardinals, mostly obscured; posterior lateral (RV) massive; LV hinge not seen; ligamental groove and nymph (RV) short; posterior margin only finely crenulate, corresponding to radial sculpture; interior obscured.

Dimensions of Protocardia (Protocardia) alta (Sowerby in Forbes).

\begin{tabular}{lccc}
\hline Specimens & Length & Height & Inflation \\
\hline GSI 1076, RV & 57 & 67 & 25 \\
ARI G2914/1, RV & 50.1 & 54.4 & 21.6 \\
ARI G2914/1, RV * & 56.9 & 66 (est.) & 23.0 \\
ARI G2914/2, LV & 29.9 & 32.0 & 11.2 \\
ARI G2914/3, RV & 21.7 & 22.9 & 8.3 \\
\hline
\end{tabular}

* Specimen G2914/1 has two RVs embedded in the same piece of sediment.

\section{Remarks}

As noted by Forbes (1846: 146), the juvenile shell of Protocardia (P.) alta, prior to the development of commarginal corrugation on the median area, appears different from the mature specimen; the fine radials, limited to the posterior area, are present at all growth stages. The species appears to be uncommon. It differs from $P$. (P.) hillana (Sowerby) in greater height and tripartite sculpture and is more oblique than $P$. (P.) bisecta (Forbes), with reduced radial sculpture.

Most of the few records of this species are from the Karai Formation. The type locality "Trichinopoly" - remains otherwise unlocalised and in need of redefinition. Of the Stoliczka material, only one specimen, GSI 1076 from Mungalpari, was located at Kolkata in February 1998. It is in a hard, grey, shelly limestone, consistent with the Turonian Kulakkalnattam Formation (Trichinopoly Group). Stoliczka's record from Uttattur may have been based on a specimen from the older western outcrop of the Karai
Formation, for which an Albian age is indicated (Ayyasami and Banerji 1984, Sundaram and Rao 1986, Sundaram et al. 2001).

\section{Occurrence}

"Trinchinopoly" (type), unlocalised (Forbes 1846). Uttattur Group. Odiyam, Uttattur (Stoliczka 1870). Karai Formation. Albian ? - Cenomanian. Odiyam Locality 3. Karai Formation (Kunnam Member). Cenomanian.

Trichinopoly Group. Mungalpari (Stoliczka 1870). Kulakkalnattam Formation. Turonian. Rare.

\section{Subfamily Profraginae Badve, 1977}

\section{Remarks}

Badve (1977: 61-64) introduced the new genus Profragum (and subfamily Profraginae) for Fragum praecurrens Stoliczka, 1870, a species from "calcareous sandstone north of Odium and west of Anapaudy". The original generic diagnosis for Profragum is: "Nearly as tall as long, more oblique than Fraginae, pallial line truncated or slightly sinuate; shell much thickened just ventrally to posterior muscle mark" (Badve 1977: 62). The time gap between "Upper Albian to Santonian", the proposed stratigraphic range of Stoliczka's species, and the first appearance of the Fraginae in the Oligocene, was emphasised by the author. The original diagnosis of the subfamily Profraginae is: "Shell trigonal, angulated posteroventrally; posterior declivity set off by a ridge; radial ribs rounded with dorsally directed blunt tubercles along crests; tubercles noticeably absent on the posterior declivity; intercostal space narrower than ribs only on the median portion; cross striae conspicuous in interspaces; hinge moderately long and bent up to $25^{\circ}$ to $30^{\circ}$ from horizontal; margins internally crenulate" (Badve 1977).

Table 13 Comparison of subfamilies Cardiinae, Fraginae and Profraginae.

\begin{tabular}{|c|c|c|c|c|}
\hline & Prominent shell characters & Cardiinae & Fraginae & Profraginae \\
\hline 1 & equilateral or nearly so & + & - & - \\
\hline 2. & Clearly inequilateral & - & + & + \\
\hline 3. & trigonal or subtrigonal, with umbonal angulation & - & + & + \\
\hline 4. & posterior margin straight, truncate & - & + & + \\
\hline 5. & postero-ventral marginal angulation & - & + & + \\
\hline 6. & rib profile symmetrical & + & - & + \\
\hline 7. & posterior ribs grooved on crests & + & - & + \\
\hline 8. & anterior, median ribs nodose & + & - & + \\
\hline 9. & posterior ribs finer, strongly discrepant & - & - & + \\
\hline 10. & hinge short, near-straight & - & - & + \\
\hline 11. & hinge extended, near-straight & + & - & - \\
\hline 12. & hinge short, angulate $\left(>25^{\circ}\right)$ & - & + & - \\
\hline 13. & teeth strong, solid & - & + & + \\
\hline 14. & teeth narrow, blade-like & + & - & - \\
\hline
\end{tabular}



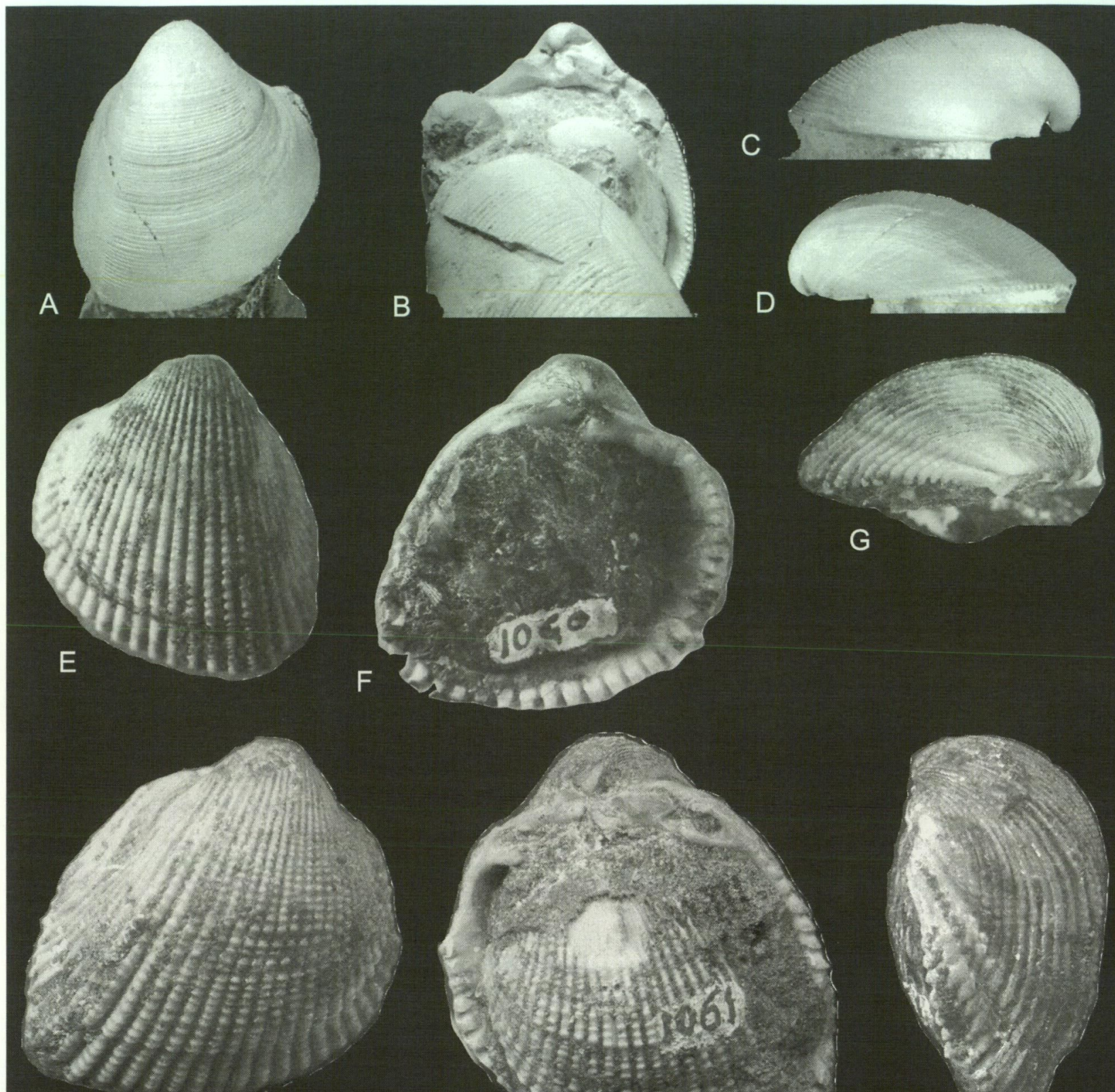

$\mathrm{H}$
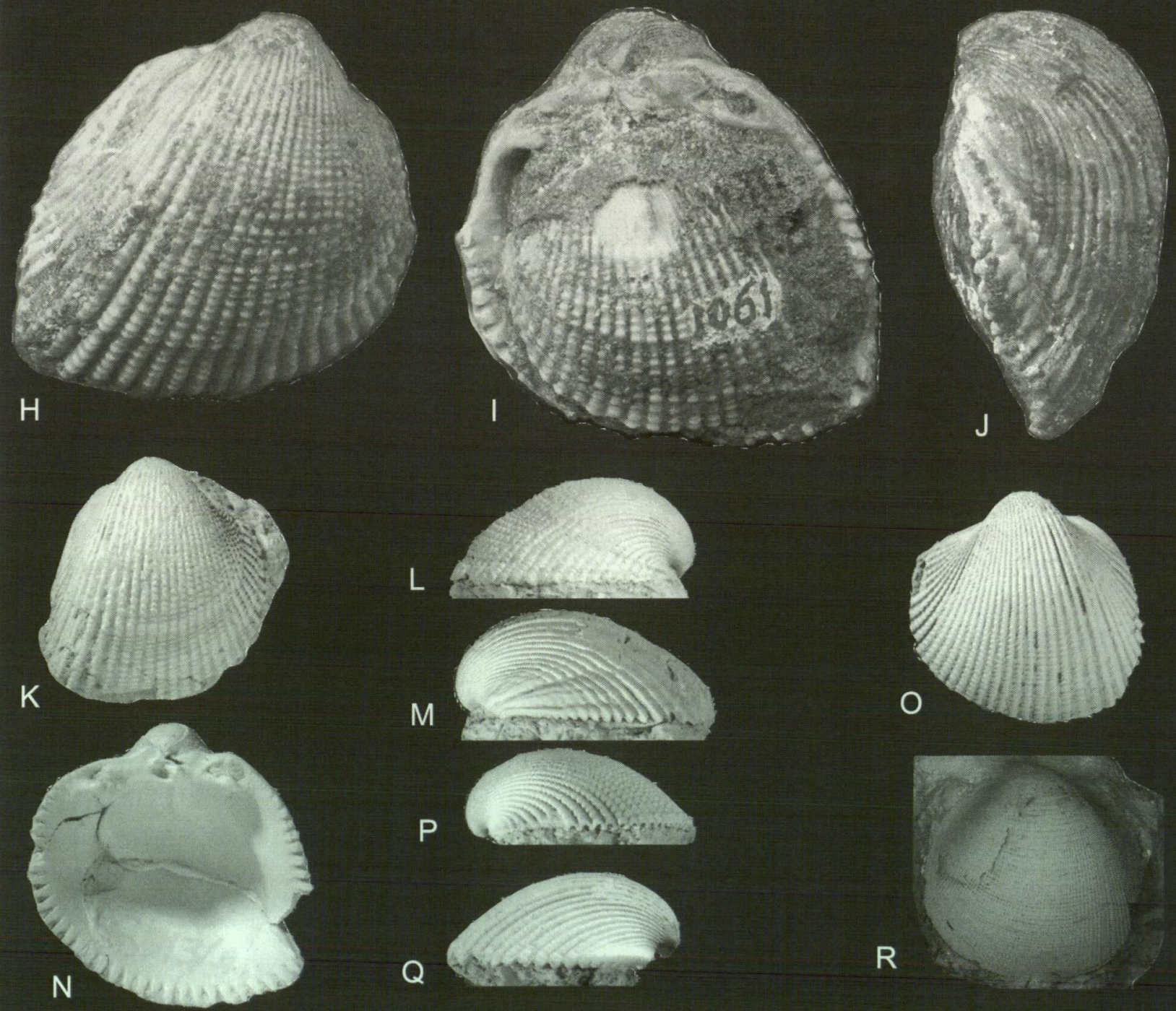

M
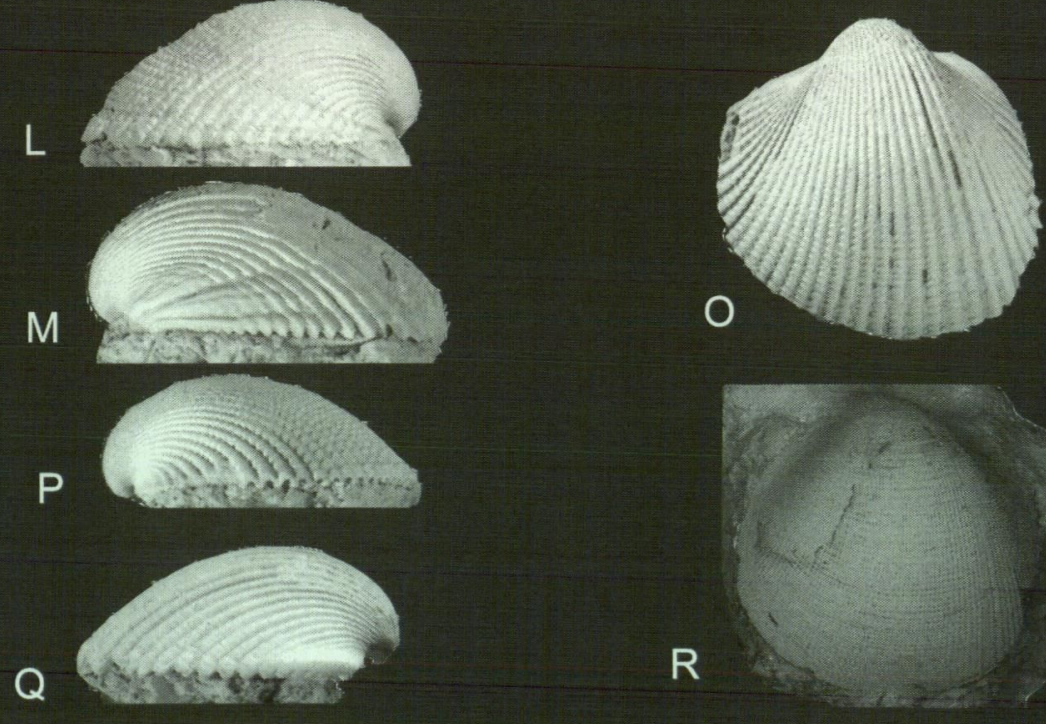

R 
Presumably unaware of Badve's (1977) paper, Keen (1980) presented diagnostic criteria for five subfamilies of the Cardiidae; of these, the "Hemidonacinae" were subsequently redefined as a full family within the Cardioidea by Ponder et al. (1981) and lie outside present considerations. Compared with Keen's criteria, Profragum praecurrens is perceived as a rather distinctive species, sharing certain characters with both the Cardiinae and Fraginae while differing significantly from both, as Table 13 shows.

From the above comparison of salient characters, the Profraginae is seen to be distinguished by the combination of a short, near-straight hinge with fine, strongly contrasting posterior sculpture. The Profraginae share three characters (all sculptural) with the Cardiinae and six (form and dentition) with the Fraginae. It does not share six characters (form, sculpture, dentition) with the Cardiinae nor six (sculpture, dentition) with the Fraginae. The other subfamilies, including the Protocardiinae, differ more substantially from Profraginae than the foregoing. This comparison thus supports recognition of the subfamily Profraginae, based on the genus Profragum Badve, 1977.

In a cladistic study of cardiid phylogeny and systematics, Schneider (1998) assigned the Cretaceous genera Austrocardium Freneix and Grant-Mackie, Indocardium Badve, Ethmocardium White and Granocardium Gabb to the Profraginae, proposing additional salient characters "secondary spines" on the intercostal spaces and a weak or absent left posterior lateral socket, as diagnostic of the subfamily. It was stated further that "examination of the type specimen of Fragum praecurrens shows that the sculpture on the interspaces is not cross-striae but secondary spines", contrary to Badve's (1977) description. Schneider's conclusions regarding the sculptural details of Profragum praecurrens apparently derive from a plaster cast of GSI Stoliczka Collection 1061, as depicted in his figs $3 \mathrm{~B}$ and 8 . A radial rib section through a shell (one of 20 specimens from Mungilpadi in the collection of the Dept of Geology, University of North Carolina, no. 15564) of the same species is shown in his fig. 9A.

In February 1998, one of us (G.W.K.) examined GSI Stoliczka Collection specimens 1060 and 1061, the type material of Fragum praecurrens Stoliczka, at Kolkata (Calcutta). The former of these was designated "holotype", i.e., lectotype, of the species by Badve (1977). On neither specimen was any feature consistent with or resembling the "secondary spines" of Schneider (1998, figs 3B, 8) observed. Stoliczka's specimens are shown in Figure $17 \mathrm{E}-\mathrm{J}$. Examination of an additional ten specimens of Profragum praecurrens from the Karai Formation at Odiyam in the present study material has failed to reveal any trace of "secondary spines" and we conclude that these are probably artefactual and a consequence of some imperfection in the casting procedure concerning GSI specimen 1061. Where visible, the intercostal spaces on the study material from Odiyam are seen to be finely striate, wholly in accordance with Badve's (1977) description and figures.

Schneider and Carter (2001: 621) described (without figuring) the shell microstructure of Profragum, presumably from a specimen of the type species: profragine morphology was compared with that of the Cenozoic Fraginae. Combined shell microstructure + morphology cladograms (Schneider and Carter 2001, figs 15, 16) of cardiid and some related groups served to emphasise the distinctiveness and systematic isolation of Profragum and the Profraginae within the Cardiidae. This result would reflect in part the alleged "secondary intercostal spines" of Profragum, regarded as invalid by the present authors.

\section{Genus Profragum Badve, 1977}

\section{Type species}

Fragum praecurrens Stoliczka, 1870 , by original designation. North of Odiyam, Uttattur Group, south India.

\section{Diagnosis (revised)}

Inflated, trapezoidal, obliquely sub-trigonal, robust; posterior margin straight, meeting ventral margin at angle of ca $90^{\circ}$; dorsal margin subauriculate and thickened posteriorly; hinge short, straight, robust; sculpture of gemmate radials on anterior-median areas; simple radials, narrowly grooved, on posterior area.

\section{Profragum praecurrens (Stoliczka, 1870)} Figure $17 \mathrm{E}-\mathrm{Q}$

1870 Fragum praecurrens Stoliczka: 222, pl. 11, figs $1,2$.

1977 Profragum praecurrens (Stoliczka); Badve: 6164, pl. 4, figs 1-9, text figs 1-3.

Figure 17 Protocardia (P.) alta (Sowerby in Forbes). A-D ARI G2914/1, RV x 0.75. A external, B hinge and internal posterior margin. C anterior area. D posterior area. Profragum praecurrens (Stoliczka). E-G, GSI 1060, lectotype, LV. E external x 1.4. F internal x 1.6. G posterior area x 1.4. H-J GSI 1061, paralectotype, RV. H external x 1.3. I internal $\times 1.5$. J posterior area $\times 1.4$. K-N ARI G2913/1, RV $\times 1$. K external. L anterior area. M posterior area. $\mathbf{N}$ ARI G2913/4, RV internal x 1.5. O-Q ARI G2913/2, LV x 1.5. O external. P posterior area. Q anterior area. Pratulum scrobiculatum (Stoliczka). R ARI G2916/1, LV external x 12 
1998 Profragum praecurrens (Stoliczka); Schneider: $37-62$, figs 3B, 8, 9A.

\section{Material examined}

\section{Lectotype}

Designated by Badve (1977). GSI Stoliczka Collection 1060, LV from "North of Odium, Ootatoor Group".

\section{Paralectotype}

GSI Stoliczka Collection 1061, RV from the type locality.

\section{Other material}

ARI G2763/2, RV, immature, Locality 2. This number shared with specimens of Nemodon filistriata (Stoliczka). G2913, five LVs, four RVs, some immature, Locality 3 . Total of 10 single valves (plus type material).

\section{Diagnosis}

Obliquely subtrigonal, usually slightly higher than long, trapezoidal, robust, inflated; anterior to median areas with 27-31 radial costae, bearing on crests crowded, dorsally directed beading; posterior area well defined by subangulate shoulder, with 11-13 simple radials, often narrowly grooved on crests; intercostal spaces finely commarginally striate; hinge plate and dorsal margin thickened; lateral teeth (RV) almost equidistant from cardinals.

\section{Description}

Medium size, height to $40 \mathrm{~mm}$, robust, obliquely subtrigonal; trapezoidal; usually slightly higher than long; umbones inflated, prosogyrate, offset from posterior area by subangulate shoulder; beak incurved, touching nymph anterior of median line; dorsal margin short, subauriculate and internally thickened, especially posteriorly; anterior margin evenly rounded to roundly subtruncate, merging into broadly rounded and obliquely descending ventral margin; latter meeting truncated, straight to slightly convex, posterior margin at angle of ca $90^{\circ}$; hinge short, almost straight, on broad hinge plate, RV cardinals $3 a$ and $3 b$ partly fused dorsally; laterals almost equidistant from cardinals, posterior closer, double on RV, not observed on LV; ligamental groove and nymph short; adductor scars lightly impressed, anterior roundly triangular, posterior larger, subquadrate, both proximate to lateral teeth; pallial line entire or slightly sinuate; margin with short internal crenulae; sculpture of anterior and median areas (AM) of 26 to 31 radial costae with narrow, finely commarginally striate interspaces, roundly symmetrical in profile, bearing on crests close, nodose, dorsally directed, commarginally aligned beading; posterior area $(\mathrm{P})$ with 11-13 simple radial costae, some narrowly grooved on crests, interspaces wider than elsewhere; costae without intercalation or bifurcation.

\section{Remarks}

The genus Profragum Badve and its subfamily remained monotypic following their introduction in 1977 until Schneider (1998: 56) noted that cardiid species from the Cretaceous of $\mathrm{W}$ Africa, assigned by Freneix (1956, 1957) and Darteville and Freneix (1957) to the genus Fragum Röding, were in "their hinge and ornamentation characters", more consistent with Profragum. "Fragum" moindouensis Freneix from the Late Cretaceous of New Caledonia was compared with "Fragum" praecurrens Stoliczka by Freneix (1958: 178, pl. 2, fig. 9), who noted the more oblique posterior truncation of the latter species and its more numerous, closer ribs. The posterior sculpture of " $F$." moindouensis seems not greatly differentiated from that elsewhere and the hinge details are unknown. That the above species may be better located in Profragum seems not unlikely but remains to be confirmed. Any such assignment would be in accord with the biostratigraphic synopsis of Schneider (1998: 55, fig. 19), whereby the profragines are confined to the Cretaceous, with Fragum appearing first in the Oligocene.

Dimensions of Profragum praecurrens (Stoliczka).

\begin{tabular}{|c|c|c|c|c|c|}
\hline Specimens & Length & Height & Inflation & AM costae & $P$ costae \\
\hline GSI 1060, LV, lectotype & 26.91 & 28.96 & 11.6 (est.) & 28 & 11 \\
\hline GSI $1061, \mathrm{RV}$, paralectotype & 35.28 & 40.46 & 16.5 (est.) & 27 & 11 \\
\hline ARI G2763/2*, RV & 21.58 & 21.78 & 11.1 (est.) & 30 & 11 \\
\hline ARI G2913/1, RV & 31.54 & 35.44 & 15.0 (est.) & 27 & 11 \\
\hline ARI G2913/2, LV & 21.90 & 21.77 & 8.1 (est.) & 28 & 13 \\
\hline ARI G2913/3, LV & 23.38 & 23.48 & 11.3 (est.) & 29 & 12 \\
\hline ARI G2913/4, RV & 27.5 (est.) & 28.08 & 12.22 & 31 & 13 \\
\hline ARI G2913/5, LV & 27.58 & 28.26 & 12.2 (est.) & $30+$ & 13 \\
\hline ARI G2913/6, LV & 26.76 & 30.30 & 14.1 (est.) & 28 & 13 \\
\hline
\end{tabular}

* This number shared with specimen of Nemodon filistriata (Stoliczka). Stoliczka's original rib counts were "35-45 rib"; in the above material, totals range from $38-44$. 
The presence in some living Cardiidae, for example, those of the genus Fragum, of a moreor-less straight, truncated, posterior margin, meeting the ventral margin at an angle up to $90^{\circ}$, has been shown to be associated with the presence of photo-symbiotic xoozanthellae in the mantle tissues (Kawaguti 1950, Ohno et al. 1995 and references). Inferred possible examples of this association in the fossil record, involving groups as old as the Permian, are reported by Ohno et al. (1995). If relevant to the present species, as seems plausible, this would suggest habitats within the photic zone for parts, at least, of both Odiyam and Kunnam Members of the Karai Formation and for part of the Kulakkalnattam Formation.

\section{Occurrence}

"In calcareous sandstone north of Odium [=Odiyam, type] and west of Anapaudy [=Anaipadi]; at the last named locality chiefly small specimens, but in very large numbers occur" (Stoliczka 1870: 222). The former of these would represent the Karai Formation (Uttattur Group), the latter probably the Turonian Kulakkalnattam Formation (Trichinopoly Group). "...grey shell limestone of the Trichinopoly Group at Mungilpadi [=Mungilpari] (Badve 1977), Kulakkalnattam Formation. Turonian. Uttattur Group. Odiyam Localities 2 and 3. Karai Formation (Odiyam and Kunnam Members). Cenomanian. Uncommon.

\section{Subfamily Laevicardiinae Keen, 1936}

\section{Remarks}

Phylogenetic studies of cardiid bivalves by Schneider $(1995,1998,2002)$ and by Schneider and Carter (2001) have favoured the location of the genus Nemocardium Meek, 1876 in the above subfamily. Pratulum Iredale, 1924, sometimes treated as a subgenus of Nemocardium, is here utilised as a full genus (A.G. Beu, personal communication, Dec. 2004).

\section{Genus Pratulum Iredale, 1924}

\section{Type species}

Cardium thetidis Hedley, 1902, by original designation. Recent, southern Australia.

\section{Pratulum scrobiculatum (Stoliczka, 1870)}

Figure $17 \mathrm{R}$

1870 Cardium (Pectunculus ?) scrobiculatum Stoliczka: 219, pl. 11, figs 14, 14a.

1979 Cardium scrobiculatum Stoliczka; Chiplonkar and Tapaswi: 145.
1987 ? Granocardium scrobiculatum (Stoliczka); Tapaswi: 511. List only.

\section{Material examined}

\section{Lectotype}

Here designated. GSI Stoliczka Collection 1073, LV (larger of two), from "Garudamungalum, Trichinopoly Group".

\section{Paralectotype}

GSI Stoliczka Collection 1073, LV (smaller of two), from the type locality.

\section{Other material}

ARI G2710, one LV, two RVs (fragments), Odiyam Locality 1; G2711, five LVs, two RVs, Locality 1; G2769, one RV, Locality 2; G2843, one LV, Locality 2; G2916, two LVs, one RV, Locality 3. Total of 15 single valves.

\section{Diagnosis}

Small, fragile, roundly subquadrate, subequilateral (immature), slightly extended anteriorly (mature); fine, close, radial costellae, faintly cancellate; costellae of equal strength on disc, wider and more spaced and with faint crestal scales on posterior area.

\section{Description}

Small, thin-shelled, fragile, roundly subquadrate, subequilateral (immature) to slightly extended anteriorly (mature); umbones inflated, broad, elevated, slightly prosogyrate, bordered by rounded to weakly angulate posterior shoulder; beaks incurved, located posterior of midline (mature); dorsal margin short, weakly shouldered at extremities; lunular area depressed; anterior and ventral margins rounded; posterior margin subtruncate (mature); sculpture of very fine, equal, close, radial costellae with linear interspaces except on anterior and posterior extremities; radials (ca 15) wider, more spaced and with faint crestal scales on posterior area; very fine subordinate, commarginal threads cancellate radials, mainly on median area; anterior extremity and beak smooth; margin with short, close internal crenulae; nymph short, low. Internal characters obscured.

Dimensions of Pratulum scrobiculatum (Stoliczka).

\begin{tabular}{lccc}
\hline Specimens & Length & Height & Inflation \\
\hline $\begin{array}{l}\text { GSI 1073, LV (larger), } \\
\quad \text { lectotype }\end{array}$ & 5.48 & 5.34 & ca 2.5 \\
$\begin{array}{l}\text { GSI 1073, LV (smaller), } \\
\quad \text { paralectotype }\end{array}$ & 3.9 & 3.8 & ca 1.7 \\
ARI G2711/1, LV & 3.86 & 3.76 & 1.50 \\
ARI G2769, RV & 14.32 & 13.6 (est.) & 6.50 \\
ARI G2916/1, LV & 4.04 & 4.03 & ca 1.6 \\
\hline
\end{tabular}




\section{Remarks}

All but one of the specimens in the study material are immature. The exception, G2769 from Locality 2 , though lacking most of the ventral extremity, appears otherwise to be of normal-mature size for the genus. This specimen may be a little more extended anteriorly than the others, possibly due to some attrition at the posterior margin. This is a very fragile species and none of the specimens to hand, all single valves, is complete; exteriors only are accessible. The original outer layer of the paralectotype appears to be substantially intact and is seen to be very finely cancellate with both radial and commarginal sculpture, the former predominant. In this aspect, the lectotype appears to be decorticated. The type material, from Garudamangalam, is in a hard, grey, calcareous rock, probably representing the Kulakkalnattam Formation (Turonian). The study material extends the range of the species into the Uttattur Group and Karai Formation.

The present species is related to Pratulum arnhemense Skwarko from the Middle or Late Cenomanian of Arnhem Land and Bathurst Island, northern Australia (Skwarko 1983, Stilwell and Henderson 2002), differing in a more even strength of the costellae across the disc and a less elevated umbone. The genus Pratulum, here recorded from the Indian Cretaceous for the first time, is characteristic of the Austral Province, Southern Temperate Realm (though with some North Temperate representation) according to Kauffmann (1973: 373). The present species is recorded from the Maastrichtian of Madagascar by Collignon (1968), cited by Chiplonkar and Tapaswi (1979: 145). Tapaswi's (1987) checklist of the south Indian Cretaceous Bivalvia included the present species, with reservation, in the genus Granocardium Gabb, 1869. However, the sculpture of Granocardium, detailed by Schneider (1998: 54, fig. $4 \mathrm{~A}$, figs $6 \mathrm{~A}, \mathrm{~B}$, figs $14 \mathrm{~A}, \mathrm{~B}$, fig. 15A) differs substantially from that of the present species which, from the available characters, appears to be a typical Pratulum.

\section{Occurrence}

Trichinopoly Group. "Garudamungalum" (type), Kulakkalnattam Formation. Turonian.

Uttattur Group. Odiyam Localities 1, 2 and 3. Karai Formation (Odiyam and Kunnam Members). Cenomanian. Uncommon.

\section{Superfamily Tellinoidea de Blainville, 1814}

Family Tellinidae de Blainville, 1814

Subfamily Tellininae de Blainville, 1814

Genus Linearia Conrad, 1860

\section{Type species}

Linearia metastriata Conrad, 1860, by monotypy. Late Cretaceous, eastern N America.

\section{Linearia sp.}

Figure $18 \mathrm{~A}$

\section{Material examined}

ARI G2844, two LVs, four RVs, Locality 2; G2917, three LVs, Locality 3. Total of nine single valves, mostly fragmentary.

\section{Description}

Small for genus, probably immature; longer than high; umbones broad, low, moderately inflated, orthogyrate; beak very small, acuminate, scarcely projecting, orthogyrate or slightly opisthogyrate, slightly anterior of centre; posterior area offset by rounded shoulder; antero-dorsal margin straight; anterior margin strongly rounded, grading into broadly arcuate ventral margin; posterior margin roundly subtruncate; postero-dorsal margin extended, straight; umbones narrowly grooved, extended; escutcheon lanceolate, shallow; ligament marginal, short; hinge obscured; sculpture apparently similar on both valves, of thin, low, spaced, commarginal costellae, obsolete on posterior area and sometimes also on median area; radial costellae confined to anterior and posterior areas, on latter, stronger and gemmate; new radials arise by intercalation; from moulds, margins apparently smooth and adductor scars lightly impressed.

Dimensions of Linearia sp.

\begin{tabular}{lccc}
\hline Specimens & Length & Height & Inflation \\
\hline ARI G2844/1, RV & 11.5 (est.) & 7.9 (est.) & 2 (est.) \\
ARI G2844/2, LV & 7.32 & 4.98 & 1.5 \\
ARI G2844/3, RV & 7.39 & 4.74 & 1.5 \\
ARI G2844/4, RV & 9 (est.) & 7 (est.) & 1.4 \\
\hline
\end{tabular}

\section{Remarks}

The study material from Odiyam differs clearly in sculptural details from both species of Linearia described by Stoliczka (1870: 130, 131, pl. 5, figs 57) and is considered to be new. The present species has a distinctive tripartite sculpture, in which the median area is variable regarding commarginal elements whilst devoid of radials. It appears to lack marginal crenulation, which distinguishes it from the subgenus Liothyris Conrad in Kerr, 1875. Naming of the species is deferred until betterpreserved material is to hand.

We note some discrepancies arising from the verification of the type material of Tellina (Linearia?) semisculpta Stoliczka and of T. (L.) sculptilis Stoliczka, the former according to the text 
from "Serdamungalum, Trichinopoly Group", the latter from Coomarapolliam, Ariyalur Group.

Stoliczka remarked of Tellina (Linearia?) semisculpta that, "The sculpture of the only specimen is so very characteristic that this species, though only known from a single imperfect specimen, can be readily distinguished from any other shell found in our south Indian cretaceous [sic.] deposits. The whole of the anterior half is ornamented with flat radiating ribs, and the entire surface besides covered with concentric striae, being rather strong as compared with the size of the shell" (Stoliczka 1870: 130). The above description applies fairly well to GSI Stoliczka Collection 954 (provided that the "flat radiating ribs" are accepted as posterior, not anterior), which, from its label purports to represent $T$. (L.) sculptilis Stoliczka. This specimen, dimensions $35 \times 17 \times 4 \mathrm{~mm}$, lacks a substantial part of the umbonal area and is clearly that shown in Stoliczka's pl. 5, fig. 6, captioned as $T$. (L.) sculptilis from "Coomarapolliam, Ariyalur Group".

This discrepancy between Stoliczka's specimen and text (p. 130) on the one hand and, on the other, his specimen label and caption, appears to have arisen around the time of publication, apparently in consequence of some mishandling of the type lots of his two Linearia species. To reorder this confusion, we accord precedence to Stoliczka's texts, whereby the description of $T$. (L.?) semisculpta is seen clearly to refer to GSI specimen 954. Subject to stratigraphic verification, that specimen could be designated lectotype of Tellina (Linearia?) semisculpta Stoliczka.

GSI specimen (Stoliczka collection) 953 (dimensions $12.5 \times 6.6 \mathrm{~mm}$ ) is an incomplete LV internal mould, lacking the antero-ventral portion and retaining shell remnants on the median and most of the posterior areas, except for the posterodorsal extremity. The posterior radial sculpture is of two kinds: distally, of narrow, close costellae (ca 5 visible), very finely beaded on crests, giving way to 10 low, flat costellae with linear, incised interspaces; costellae end abruptly. Median area bears very fine, close commarginal striae, which extend posteriorly over the low, flat, radial costellae. The anterior fourth of the specimen is missing. We regard this specimen as probably part of Stoliczka's original material of Tellina (Linearia) sculptilis, according precedence to his text and specimen over the caption (Pl. 5, fig. 5) and specimen label.

Both of Stoliczka's species of Linearia (and also that from Odiyam) are poorly known and his figures (1870, pl. 5, figs 5-7) are less than satisfactory depictions of the specimens, except for the distinctive umbonal damage on specimen 954 , which helps to recognise that specimen as the lectotype of L. semisculpta (Stoliczka). Stratigraphic verification of both the Stoliczka species is desirable.

\section{Occurrence (present species)}

Uttattur Group. Odiyam Localities 2 and 3. Karai Formation (Odiyam and Kunnam Members). Cenomanian. Rare.

\section{Genus Aenona Conrad, 1870}

\section{Type species}

Tellina eufaulensis Conrad, 1860, by subsequent designation of Stoliczka 1871. Maastrichtian, $N$ America.

\section{Aenona? ariana sp. nov. Figure $18 \mathrm{~B}-\mathrm{D}$}

\section{Material examined}

\section{Holotype}

ARI G4354, LV, from brown calcareous siltstone with abundant turritellid gastropods beside track $\mathrm{ca}$ $0.5 \mathrm{~km}$ west of Odiyam village, Perambalur Taluk, Tiruchirapalli district, Tamil Nadu (Locality 2).

\section{Paratypes}

ARI G2714, eight RVs, one conjoined pair (postero-dorsal portion only), Locality 1. Total of ten specimens.

\section{Diagnosis}

Small, elliptical Aenona ? with slightly opisthogyrate beaks, well developed lunule and escutcheon; sculpture of faint commarginal costellae, posteriorly obsolete.

\section{Description}

Small, length to ca $14 \mathrm{~mm}$, thin, elliptical, longer than high, subequilateral; umbones broad, slightly inflated; beaks submedian, slightly opisthogyrate and projecting; posterior area weakly defined; lunule and escutcheon lanceolate, opaque, occupying most of dorsal area, former narrower and bordered by weak striation; escutcheon wider, bordered by well-defined ridge; ligament concealed, apparently internal; dorsal margins subequal, almost straight, symmetrically descending and subtending angle of $130^{\circ}$; anterior and posterior margins about evenly rounded, latter without flexure; sculpture of faint commarginal costellae with narrow interspaces, obsolete posteriorly and dorsally; ventral margin internally smooth; pallial sinus (from mould) faintly discernible, possibly broad; other internal characters unknown. 
Dimensions of Aenona? ariana sp. nov.

\begin{tabular}{lccc}
\hline Specimens & Length & \multicolumn{2}{c}{ Height } \\
\hline ARI G4354, LV, holotype & $11.8^{*}$ (est.) & 6.85 & 3 (est.) \\
ARI G2714, RV, paratype & 13.7 (est.) & 8.4 (est.) & 4 (est.) \\
\hline
\end{tabular}

* slightly damaged at each end

\section{Remarks}

In most of the available, i.e. external features, the present species resembles Aenona eufaulensis (Conrad) from the Ripley Formation, Prairie Bluff Formation and other Maastrichtian units of central west and southeastern North America (Wade 1926, Afshar 1969) and is assigned provisionally to that genus. Apparent differences include the slightly opisthogyrate beaks and more conspicuous lunule, escutcheon and sculpture. Generic confirmation would depend on access to internal characters, particularly the hinge, at present not available.

Comparison of the present species with the type material of Tellina (Tellinella) petrosa Stoliczka from the "Trichinopoly Group" of "Garudamungalum", probably from the Turonian Kulakkalnattam Formation, shows that the two species are not dissimilar and possibly congeneric. Stoliczka's specimens, both RVs, are essentially internal moulds retaining some shell fragments. The better of these, GSI 1146, shows sculpture of fine, close, commarginal costellae on the antero- and postero-dorsal areas and is here designated lectotype of Tellina (Tellinella) petrosa Stoliczka; this is figured on Stoliczka's (1870) pl. 16, figs 27, 27a. GSI 1147 (figured pl. 16, figs 28, 28a) becomes paralectotype of that species. The Odiyam species is, in comparison, longer relative to height, has both lunule and escutcheon more clearly defined and the sculpture, as far as can be seen, is distributed differently. Internal characters of both species remain to be determined.

In external features, the present species is not unlike Tellinimera scitula (Meek and Hayden) from the Maastrichtian Fox Hills Formation of South Dakota (Speden 1970: 131-134, pl. 33, figs 3-15), differing in the absence of any posterior flexure and projecting nymph, and in showing a more equilateral profile. Most specimens in the study material are from Odiyam Locality 1 , from where it has been very difficult to extract them undamaged from the hard matrix. The holotype, from Locality 2 , is slightly damaged at each end. Subject to confirmation, this would be the first record for the genus from the Cretaceous of south India.

\section{Etymology}

The specific name, from the acronym of the Agharkar Research Institute, Pune, acknowledges with appreciation the generous support of that institution and staff for this study.

\section{Occurrence}

Uttattur Group. Odiyam Localities 1 and 2 (type). Karai Formation (Odiyam and Kunnam Members). Cenomanian. Uncommon.

\section{Superfamily Veneroidea Rafinesque, 1815}

Family Veneridae Rafinesque, 1815

Subfamily Pitarinae Stewart, 1930

Genus Aphrodina Conrad, 1869

\section{Type species}

Meretrix tippana Conrad, 1858, by original designation. Late Cretaceous, Mississippi.

\section{Subgenus Aphrodina s. str}

\section{Aphrodina (Aphrodina) plebeia sp. nov.} Figure $18 \mathrm{E}$

\section{Material examined}

Holotype

ARI G2846/1, LV, from brown calcareous siltstone with abundant turritellid gastropods, beside track ca $0.5 \mathrm{~km}$ west of Odiyam village, Perambalur Taluk, Tiruchirapalli district, Tamil Nadu (Locality 2).

\section{Paratypes}

ARI G2846/2-17, five LVs, six RVs, one RV internal mould, four conjoined pairs, from the type locality. Total of 17 specimens.

\section{Other material}

ARI G2717, 11 LVs, 10 RVs, two conjoined pairs, Locality 1; G2792, seven LVs, five RVs, Locality 2; G2846, 179 mostly single valves, Locality 2; G2921, four LVs, five RVs, Locality 1 . Total of 240 specimens.

\section{Diagnosis}

Small for genus, length to $7 \mathrm{~mm}$, moderately inflated; lunule large, weakly differentiated, not recessed; sculpture of low, irregular, commarginal costellae, often stepped, becoming obsolete toward apical area.

\section{Description}

Small, robust, ovate, subequilateral; umbones moderately inflated, slightly prosogyrate, elevated; beak incurved, prosogyrate, slightly anterior of centre; lunule large, not recessed, weakly differentiated, bordered by incised line; escutcheon wanting; ligament submarginal; antero- and postero-dorsal margins almost 


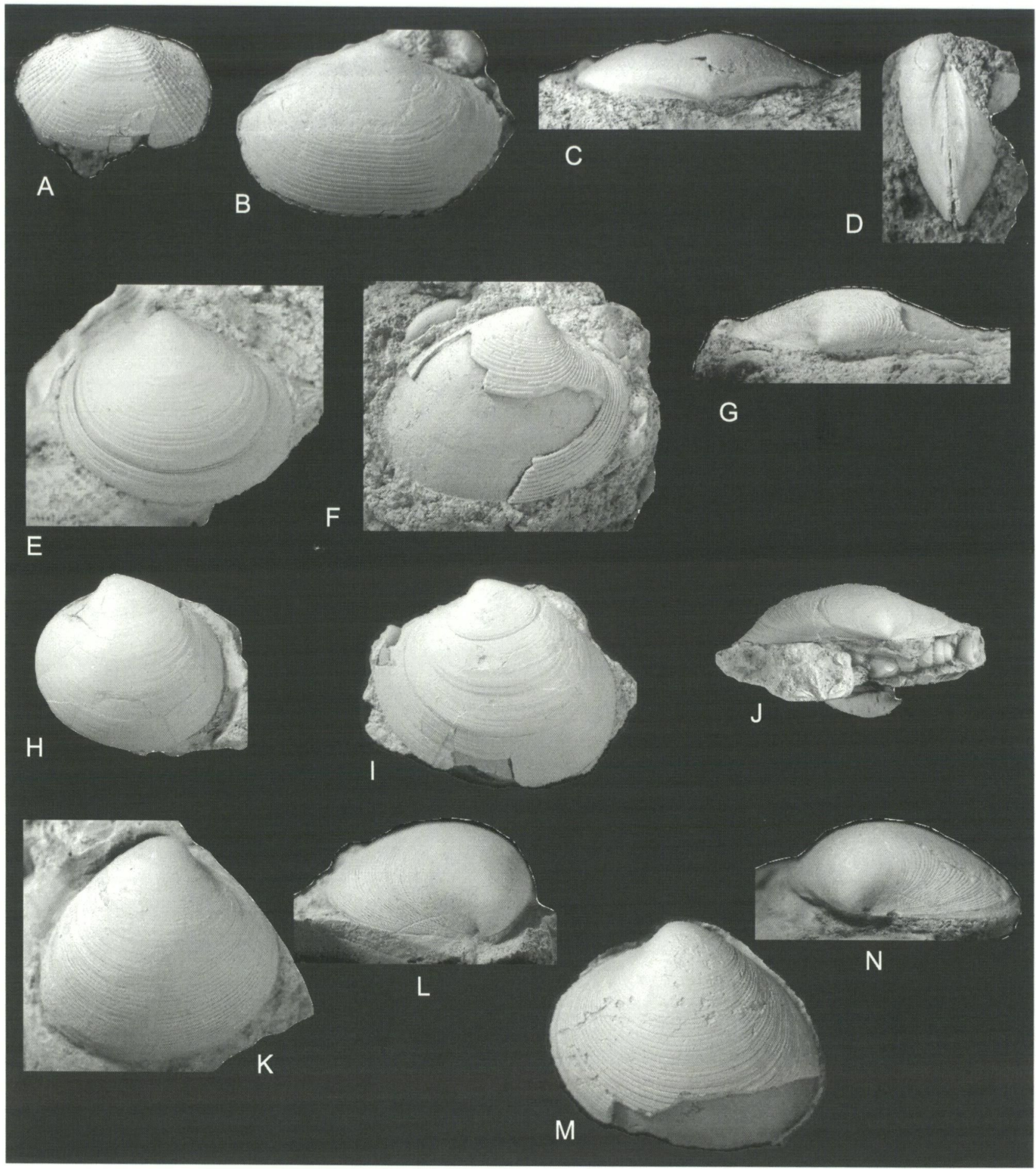

Figure 18 Linearia sp. A ARI G2844/2, LV external x 4. Aenona ? ariana sp. nov. B ARI G4354, holotype, LV external x 4. C ARI G2714/1, paratype, RV dorsal aspect x 3. D ARI G2714/8, postero-dorsal area of incomplete conjoined pair x 4. Aphrodina (A.) plebeia sp. nov. E ARI G2846/1, holotype, LV external x 5. Aphrodina (A.) fabulina (Stoliczka). F, G ARI G2920/1, RV external x 2 and dorsal aspect x 2. Mesocallista (M.) sp. cf. M. (M.) analoga (Forbes). H ARI G2793/1, LV external x 2. I, J ARI G2793/3, LV external and dorsal aspect x 2. Mesocallista (M.) vagrans (Stoliczka). K, L ARI G2919/1, RV external and anterior flank with lunular incision x 4. M, N ARI G2919/8, LV external and anterior flank showing lunular incision x 4.

straight, subtending angle of ca $120^{\circ}$; other margins rounded, ventral broadly, posterior subtruncate; sculpture of low, irregular, ridged, commarginal costellae, transgressing lunule, often stepped by growth pauses; hinge mostly obscured, LV tooth A II strong, oblique to and below margin, 2a long, curved, $2 \mathrm{~b}$ shorter, divergent, $4 \mathrm{~b}$ long, blade-like; RV hinge obscured; from moulds, adductor scars ovate, lightly impressed, posterior larger; pallial line remote from margin, sinus not discerned; margin internally bevelled, without crenulae. 
Dimensions of Aphrodina (Aphrodina) plebeia sp. nov.

\begin{tabular}{lccc}
\hline Specimens & Length & Height & Inflation \\
\hline ARI G2846/1, LV, holotype & 7.04 & 5.77 & 1.69 \\
ARI G2846/2, LV, paratype & 7.07 & 5.65 & 1.67 \\
ARI G2846/3, RV, paratype & 5.58 & 4.88 & 1.59 \\
ARI G2846/4, RV, paratype & 6.98 & 5.65 & 1.71 \\
ARI G2846/5, pair, paratype & 5.06 & 4.32 & 2.99 \\
\hline
\end{tabular}

\section{Remarks}

This small, distinctive species with much reduced sculpture does not closely resemble any other known species of Aphrodina from south India, being longer relative to height than $A$. laciniata (Stoliczka) (Niniyur Formation) and more inflated than $A$. (A.) fabulina (Stoliczka) (Karai and Kulakkalnattam Formations). It is the most common bivalve species from Locality 2 and in the study material as a whole is inferior in numerical representation only to Paramyrtea sabulosa gen. nov., sp. nov. (above). Conjoined pairs, all small, occur occasionally; five single valves (both localities) show naticiform boreholes, a low predation rate of ca $2.3 \%$.

\section{Etymology}

From the Latin plebeia (fem.), of the common people or multitude. A very common species.

\section{Occurrence}

Uttattur Group. Odiyam Localities 1 and 2 (type). Karai Formation (Odiyam and Kunnam Members). Cenomanian.

\section{Aphrodina (Aphrodina) fabulina (Stoliczka, 1870)} Figure 18 F, G

1870 Cytherea (Callista) fabulina Stoliczka: 174, pl. 16 , figs 31-33.

1987 Aphrodina (Aphrodina) fabulina (Stoliczka); Tapaswi: 512. List only.

\section{Material examined}

\section{Lectotype}

Here designated. GSI Stoliczka Collection 1150, $\mathrm{LV}$ in hard, brown, shelly limestone from "Garudamungalum, Trichinopoly group" [sic.]. Figured Stoliczka, pl. 16, figs 32, 32a.

\section{Paralectotypes}

GSI Stoliczka Collection 1149 and 1151, RVs from "near Odium, Ootatoor Group". Figured Stoliczka, pl. 16, figs 31,33 respectively.

\section{Other material}

ARI G2920, four LVs, $11 \mathrm{RVs}$, Odiyam Locality 3. Total of 15 single valves, none complete (plus type material).

\section{Diagnosis}

Medium sized, length to $21 \mathrm{~mm}$, ovate, moderately inflated Aphrodina s. str. with well defined, shallow lunule; sculpture of numerous fine, close, commarginal costellae, as wide as interspaces over entire surface (beak smooth).

\section{Description}

Medium-sized, ovate, inequilateral, longer than high, rather thin, brittle; umbones moderately inflated, prosogyrate, elevated; beak incurved, prosogyrate, almost at anterior third; antero-dorsal margin short, slightly concave; postero-dorsal margin longer, slightly convex; other margins rounded, ventral broadly so; lunule large, shallow, bordered by incised line; escutcheon wanting; ligament external, on low, extended nymph; sculpture of fine, close, regular, commarginal costae, ca 65 in height of $15 \mathrm{~mm}$, asymmetric in cross section, short and steep on dorsal side; discrepant commarginal costae on lunule; beak smooth; hinge (LV) tooth $4 \mathrm{~b}$ long, blade-like, oblique; $2 \mathrm{~b}$ shorter, narrow, slightly divergent from $4 b ; 2 a$ missing; (RV) tooth I vertical, short, thin; $3 a$ thin, divergent from and longer than $\mathrm{I} ; 3 \mathrm{~b}$ oblique, long, bladelike, bifid; laterals obscured; from moulds, adductor scars lightly impressed; margin without crenulae.

Dimensions of Aphrodina (Aphrodina) fabulina (Stoliczka).

\begin{tabular}{lccc}
\hline Specimens & Length & Height & Inflation \\
\hline GSI 1150, LV, lectotype & 15.8 & 12.2 & ca 4 \\
GSI 1149, RV, paralectotype & $21.1^{*}$ & 16.2 & ca 6 \\
ARI G2920/1, RV & 21 (est.) & 16.0 & 4.4 \\
ARI G2920/2, RV & 16.3 & 12.5 & 4.0 \\
\hline
\end{tabular}

* postero-ventral portion missing

\section{Remarks}

Odiyam specimens G2920 have been compared with the Stoliczka type material of Cytherea (Callista) fabulina and are considered to be conspecific. Lectotype GSI 1150, in a hard, brown, shelly limestone from Garudamangalam, is the best preserved of the three specimens. Paralectotypes from near Odiyam both lack the postero-ventral area; both are in hard shelly limestones, the former brown, the latter greyishbrown. Related species, all from the Ariyalur Group, are Aphrodina sculptura, A. laciniata and A. minutula, all of Stoliczka. From these, the present species differs (judging from the figures) in its finer, closer sculpture. From $A$. (A.) plebeia sp. nov., it differs in larger size, reduced inflation, well defined lunule and more extensive sculpture. 


\section{Occurrence}

Trichinopoly Group. Garudamangalam (type), Kulakkalnattam Formation. Turonian.

Uttattur Group. "near Odium" (Stoliczka 1870). Odiyam Locality 3. All Karai Formation (Kunnam Member). Cenomanian. Uncommon.

\section{Genus Mesocallista Cox, 1952}

\section{Type species}

Meretrix andersoni Newton, 1909, by original designation. Late Cretaceous, W Africa.

\section{Subgenus Mesocallista s. str}

\section{Mesocallista (Mesocallista) sp. cf. M. (M.) analoga (Forbes, 1846)}

Figure $18 \mathrm{H}-\mathrm{J}$

\section{Material examined}

ARI G2793, three LVs, one RV, Locality 2; G2918, two LVs, three RVs, Locality 3; G2975, one LV, one RV (fragmentary), Locality 1 . Total of 11 single valves.

\section{Description}

Medium-sized for genus, length to $20 \mathrm{~mm}$, ovate, longer than high, thin-shelled but robust; umbones moderately inflated, prosogyrate, slightly elevated; beak prosogyrate, anterior of centre; antero-dorsal margin short, almost straight; postero-dorsal margin longer, slightly convex; anterior and ventral margins broadly rounded; posterior margin roundly subtruncate; lunule broad, shallow, bordered by incised line; escutcheon narrow, bordered by subangulate shoulder; ligament marginal, visible externally; surface polished, occasionally with dark, commarginal colour bands; sculpture of very fine, growth striae, extending over lunule and accentuated slightly on flanks; no radial sculpture; beak smooth; margin without crenulae; hinge and other internal characters obscured.

Dimensions of Mesocallista (Mesocallista) sp. cf. M. (M.) analoga (Forbes).

\begin{tabular}{lccc}
\hline Specimens & Length & Height & Inflation \\
\hline ARI G2793/1, LV & 15.32 & 14.66 & 5.3 \\
ARI G2793/2, RV & 11.53 & 9.57 & 3.5 \\
ARI G2793/3, LV & 20.13 & 17.24 & 4.9 \\
\hline
\end{tabular}

\section{Remarks}

Specimens G2793/1-3 have been compared with the type material of Venus analoga Forbes, 1846 in the Kaye and Cunliffe Collection, Natural History Museum, London, Geology Dept no. L56575 and Geological Society no. R10611. The former is a small $\mathrm{RV}$ of length $8 \mathrm{~mm}$ (est.), height $7.14 \mathrm{~mm}$, inflation
$3 \mathrm{~mm}$ (est.); the latter an LV with estimated dimensions $20 \mathrm{~mm} \times 15.5 \mathrm{~mm} \times 5 \mathrm{~mm}$. Both are from "Trichinopoly". In size, shape and sculpture, R10611 is very close to G2793/3 but is damaged on the escutcheon and the lunule is obscured. Specimen L56571 is similar to the small RVs from Odiyam but its lunule is also obscured. On none of this material are internal characters available for comparison. We designate Geological Society specimen R10611 to be lectotype and Geology Department specimen L56575 thus becomes paralectotype of Venus analoga Forbes, 1846.

Stoliczka (1870: 178, 179, pl. 5, figs 21-23) applied Forbes' name, as Cyprimeria analoga (Forbes), to venerids from the Trichinopoly and Ariyalur Groups. Compared with the present material, his specimens are much larger (length $54 \mathrm{~mm}$ ), compressed, lack a lunule and appear to be much more strongly sculptured, hence their conspecificity seems doubtful. The presence of a lunule and other characters (Keen in Moore 1969: N681) preclude the study material from the genus Cyprimeria Conrad, 1864. Determination of the Odiyam material remains qualified and its assignment to the genus Mesocallista is provisional; it differs from the following species in the absence of regular, welldefined commarginal costellae. "Venus" analoga Forbes remains a poorly defined species of uncertain generic and stratigraphic locations and the collection of further material from the type area is needed to clarify these questions.

\section{Occurrence}

Uttattur Group. Odiyam Localities 1, 2 and 3. Karai Formation (Odiyam and Kunnam Members). Cenomanian. Uncommon.

\section{Mesocallista (Mesocallista) vagrans (Stoliczka, 1870) \\ Figure $18 \mathrm{~K}-\mathrm{N}$}

1870 Cytherea (Callista) vagrans Stoliczka: 176, pl. 7, figs 21-23.

1987 Mesocallista (Mesocallista) vagrans (Stoliczka); Tapaswi: 512. List only.

\section{Material examined}

Lectotype

Here designated. GSI Stoliczka Collection 1013, LV from south of Garudamangalam.

\section{Paralectotypes}

GSI Stoliczka Collection 1012, LV from Garudamangalam; 1014, RV from "Karaupaudy".

Other material

ARI G2716, three LVs, Odiyam Locality 1; G2791, 
five LVs, three RVs, Locality 2; G2919, 1 conjoined pair, ten LVs, $11 \mathrm{RVs}$, Locality 3. Total of one conjoined pair and 32 single valves (plus type material).

\section{Diagnosis}

Small for subgenus, subtrigonal, inflated, length exceeding height; apical area smooth, otherwise with very fine, close, regular, commarginal costellae and narrower interspaces; lunule large, indicated solely by incised line; escutcheon small.

\section{Description}

Small for subgenus, height to $14 \mathrm{~mm}$, roundly subtrigonal, subequilateral, length exceeding height; thin but robust; umbones inflated, prosogyrate, elevated; beak incurved, prosogyrate, anterior of centre; antero-dorsal margin almost straight; postero-dorsal margin longer, slightly convex; anterior, ventral and posterior margins rounded, latter subtruncate; lunule large, not recessed, bordered by incised line; escutcheon small, narrowly recessed, bordered by weak shoulder; ligament marginal; apical $3 \mathrm{~mm}$ smooth, thereafter disc with very fine, close, regular commarginal costellae and narrower interspaces, intensified on flanks and passing across lunule; teeth $3 \mathrm{~b}$ and $4 \mathrm{~b}$ visible on some specimens, otherwise hinge obscured; from moulds, adductor scars and pallial line lightly impressed to obscure; margin without crenulae.

Dimensions of Mesocallista (Mesocallista) vagrans (Stoliczka).

\begin{tabular}{lccc}
\hline Specimens & Length & Height & Inflation \\
\hline GSI 1013, LV, lectotype & 7.28 & 6.43 & - \\
ARI G2791/1*, LV & - & 14.2 (est.) & 5.6 \\
ARI G2919/1, RV & 10.43 & 9.43 & 3.8 \\
ARI G2919/2, RV & 10.94 & 10.66 & 3.9 \\
ARI G2919/3, RV & 11.83 & 9.83 & 4.1 \\
ARI G2919/4, LV & 12.68 & 10.80 & 4.3 \\
\hline
\end{tabular}

* largest specimen

\section{Remarks}

The study material has been compared with the type material of Cytherea (Callista) vagrans Stoliczka, comprising the following:

GSI 1012, LV from Garudamangalam, Trichinopoly Group, fig'd pl. 7, figs 21, 21 a.

GSI 1013, LV from S of Garudamangalam, Trichinopoly Group, fig'd pl. 7, fig. 22.

GSI 1014, RV from Karapadi, Ariyalur Group, fig'd pl. 7, figs 23, 23a.

Of these, the best preserved is 1013, a complete $\mathrm{LV}$ in grey limestone, here designated lectotype of Cytherea (Callista) vagrans Stoliczka. Specimens 1012 and 1014, in dark brown and pale brown limestones respectively, are of inferior preservation and are designated paralectotypes of that species. ARI specimen G2919/1 from Odiyam Locality 3 very closely resembles GSI 1013 and we consider that the former, together with the balance of the study material from Odiyam, to be referable to Stoliczka's species, a first record for the Uttattur Group of this apparently long-ranging species.

The present species differs from Mesocallista (M.) sp. cf. analoga (Forbes) by its greater inflation and commarginal sculpture; from $M$. (M.) turgidula (Stoliczka) by its smooth apical area. One specimen (G2919/9) from Odiyam shows on the umbo a medium-sized, bevelled, naticiform borehole.

\section{Occurrence}

Uttattur Group. Odiyam Localities 1, 2 and 3. Karai Formation (Odiyam and Kunnam Members). Cenomanian.

Trichinopoly Group. Garudamangalam and south of (type). Kulakkalnattam Formation. Turonian.

Ariyalur Group. Karapadi. Sillakkudi Formation. Santonian-Campanian.

\section{Mesocallista (Mesocallista?) sp. Figure 19 A, B}

\section{Material examined}

ARI G2922, one LV, one RV, Locality 3; G2960, two LVs, two RVs, Locality 1 . Total of six single valves, none complete.

\section{Description}

Large for subgenus, length to $22 \mathrm{~mm}$, roundly subtrigonal, subglobose, longer than high, thinshelled; umbones strongly inflated, prominently elevated, prosogyrate; beak incurved, anterior of centre, prosogyrate; antero-dorsal margin short, almost straight; postero-dorsal margin longer, descending, slightly convex; other margins more or less evenly rounded; lunule large, not recessed, bordered by faint, incised line; escutcheon small, shallow, weakly defined; ligament marginal; sculpture of very fine, faint commarginal growth striae, slightly intensified on flanks, passing over lunule, occasionally stepped by growth pauses; apical area smooth; radial sculpture absent; from moulds, margin without crenulae, adductor scars lightly impressed, pallial line distant from margin; hinge obscured.

Dimensions of Mesocallista (Mesocallista?) sp.

\begin{tabular}{lccc}
\hline Specimens & Length & Height & Inflation \\
\hline ARI G2922/1, LV & 15 (est.) & 13.12 & 4.7 \\
ARI G2960/1, RV & 22.5 & 20.44 & 6.2 \\
ARI G2960/2, LV & 13.86 & 12.94 & 4.4 \\
\hline
\end{tabular}




\section{Remarks}

This species is distinguished from all other venerids in the study material by its relatively large, strongly inflated, almost smooth, subtrigonal shell. It should not be confused with juvenile Aphrodina plana (Sowerby), differing in greater inflation, reduced lunule and escutcheon and near-straight antero-dorsal margin. In the absence of hinge details, the generic assignment remains provisional. The species may be new but the available material is unsuitable for type designation.

\section{Occurrence}

Uttattur Group. Odiyam Localities 1 and 3. Karai Formation (Kunnam Member). Cenomanian. Rare.

\section{Order Myoida Stoliczka, 1870}

\section{Superfamily Myoidea Lamarck, 1809}

Family Corbulidae Lamarck, 1818

Subfamily Corbulinae Gray, 1823

Genus Caryocorbula Gardner, 1926

\section{Type species}

Corbula alabamiensis Lea, 1833, by original designation. Middle Eocene, southeastern N America.

\section{Caryocorbula minima (d'Orbigny, 1847)}

Figure $19 \mathrm{~F}-\mathrm{K}$

1847 Corbula minima d'Orbigny, pl. 5, figs 18, 19.

1870 Corbula minima d'Orbigny; Stoliczka: 44, 45, pl. 1, figs 19, 20, pl. 16, figs 7-12.

1987 Corbula minima d'Orbigny; Tapaswi: 512. List only.

\section{Material examined}

GSI Stoliczka Collection 900, 901, 902, 903, mixed samples together totalling 20 small bivalves, of which 11 (one conjoined pair, five LVs, four RVs, one internal mould) are of present species. ARI G2720, 147 single valves, 3 conjoined pairs, Locality 1; G2795, 86 single valves, 12 conjoined pairs, Locality 2; G2924, nine single valves, Locality 3. Total of 252 single valves and 16 conjoined pairs.

\section{Diagnosis}

Very small, length to $6 \mathrm{~mm}$, longer than high; valves discrepant, $R V$ larger, both carinate; $L V$ posteriorly truncate, RV posteriorly subrostrate; sculpture commarginal, of variable strength and spacing, obsolete apically, occasionally with faint radial striae (either valve).

\section{Description}

Very small, trigonal, thin-shelled, longer than high, plane of greatest length below centre; umbones inflated, elevated; beaks prosogyrate, anterior of centre, proximate; escutcheon narrow, shallow; lunule wanting; ligament internal; posterior areas (both valves) offset by umbonal carinae; valves discrepant, RV slightly larger, ventrally incurved and enfolding margin of LV; sculpture of low, irregular, commarginal costellae of variable strength and spacing, oblique to margin anteriorly and becoming obsolete apically; occasionally crossed on disc, rarely on posterior area, by faint to obscure, thin radial striae (either valve); from moulds, adductor scars large, lightly impressed, anterior ovate, at anterior extremity, posterior on postero-dorsal area; pallial line faint, remote; margins smooth; hinge obscured. Valves decorticate freely, reducing angularity of umbonal carinae and changing proportions.

Dimensions of Caryocorbula minima (d'Orbigny).

\begin{tabular}{lccc}
\hline Specimens & Length & Height & Inflation \\
\hline ARI G2720/1, conjoined pair & $4.30^{*}$ & $3.20^{*}$ & 2.42 \\
ARI G2720/2, RV & 5.11 & 3.36 & 1.5 \\
ARI G2720/3, LV & 4.08 & 2.89 & 1.0 \\
ARI G2795/1, RV & 6.10 & 3.78 & 2.0 \\
ARI G2795/2, LV & 4.67 & 3.36 & 1.5 \\
\hline
\end{tabular}

* actually dimensions of the larger RV

\section{Remarks}

Specimens attributed to Corbula minima d'Orbigny in the GSI Stoliczka Collection, Kolkata are accompanied by labels numbered 900, 901, 902 and 903 . This is a mixed sample, comprising eleven specimens (one pair, five LVS, four RVs, one internal mould) of the present species and nine other small bivalves, two of which appear to be the species discussed below as Barcoona? gradilis sp. nov. and possibly depicted in Stoliczka's (1870) plate 1, figs 19, 20. The eleven corbulid specimens agree with Stoliczka's description (and most figures) of $C$. minima and with the present study material from Odiyam. Stoliczka's locality: "In dark brown sandy and cherty limestone; north of Odium; not rare". This and the following species agree with the salient characters of Caryocorbula, as redefined by Vokes (1945) and by Squires and Saul (2004:108, 110).

As noted by Stoliczka, Caryocorbula minima varies a little in the proportions of the valves, in the degree of posterior rostration (RV) and in the strength, spacing and persistence of the sculpture. The apical area is usually smooth but costellae may extend occasionally to the beak. Faint, spaced radial striation occurs on either disc or area of either valve. The present species is readily distinguished from the associated and somewhat rare $C$. 
cauveriensis sp. nov. by its reduced size (length to 6 $\mathrm{mm}$ ), more elevated umbones (which are carinate posteriorly), the beaks closer to the midline and the presence of faint radial striae.

One of the more common elements in the Odiyam material (particularly from Localities 1 and 2), the present species occurs mainly as disarticulated valves; about $6 \%$ are conjoined pairs. Sixteen valves from Localities 1 and 2 show gastropod boreholes of bevelled-naticiform and possibly other kinds, a predation rate of $6 \%$. Four of these are on LVs and 12 on RVs, all successful. Though the sample is small, these data are in accord with the apparent gastropod bias favouring corbulid RVs, as noted by De Cauwer (1985).

\section{Occurrence}

Ariyalur Group. Senonian of Pondicherry (type, d'Orbigny, 1847). Probably from either Valudavur or Mettuveli Formation. Maastrichtian.

Uttattur Group. "North of Odium" (Stoliczka 1870). Odiyam Localities 1, 2 and 3. Karai Formation (Odiyam and Kunnam Members). Cenomanian. Common.

\section{Caryocorbula cauveriensis sp. nov. Figure $19 \mathrm{C}-\mathrm{E}$}

\section{Material examined}

\section{Holotype}

ARI G2787/1, LV, from brown calcareous siltstone with abundant turritellid gastropods, beside track ca $0.5 \mathrm{~km}$ west of Odiyam village, Perambalur Taluk, Tiruchirapalli district, Tamil Nadu (Locality 2).

\section{Paratypes}

ARI G2708, three LVs, Locality 1; G2787/2-8, one LV, six RVs from type locality. Total of 11 single valves.

\section{Diagnosis}

Small, length to $10 \mathrm{~mm}$, thin-shelled, beaks at anterior two fifths, valves subequal, RV slightly more inflated, each with posterior-umbonal angulation; escutcheon long, shallow; sculpture of fine, close, commarginal costellae, extending over posterior area, obsolete toward beaks.

\section{Description}

Small, thin-shelled, longer than high, valves subequal, RV slightly more inflated; posterior area of each valve slightly concave and bordered by umbonal angulation; beaks at anterior two fifths, prosogyrate; lunule wanting; escutcheon slender, shallow, occupying entire postero-dorsal margin; chondrophore (LV) broad, projecting with thin radial ridge on dorsal side; antero-dorsal margin short, almost straight; anterior margin short, wellrounded; ventral margin broadly arched, slightly descending anteriorly; posterior margin truncate, subrostrate ventrally; postero-dorsal margin slightly arched; sculpture of very fine, close, commarginal costellae extending over posterior area, becoming obsolete apically; beaks smooth; from internal moulds, RV cardinal tooth large, hook-like; adductor scars lightly impressed, posterior larger, bordered by narrow groove on anterior side; pallial line obscure.

Dimensions of Caryocorbula cauveriensis sp. nov

\begin{tabular}{lccc}
\hline Specimens & Length & Height & Inflation \\
\hline ARI G2787/1, LV, holotype & 8.44 & 5.93 & 1.8 \\
ARI G2787/2, RV, paratype & 9.13 & 6.37 & 2.1 \\
ARI G2787/3, RV, paratype & 9.98 & 7.17 & 2.2 \\
\hline
\end{tabular}

\section{Remarks}

Though known only from disassociated single valves, the lefts and rights of this uncommon species are substantially alike. In the conjoined state, the RV will probably be found to be slightly more inflated and slightly larger than the LV. The species is possibly ancestral to Caryocorbula cancellifera (Stoliczka) from Garudamangalam, probably from the Turonian Kulakkalnattam Formation (Trichinopoly Group). It differs from the associated and very common $C$. minima (d'Orbigny) in its greater size, lower umbones, more anterior beaks, less carinate and rostrate posterior and absence of radial striation.

\section{Etymology}

From the Cauvery River and sedimentary basin of south India.

\section{Occurrence}

Uttattur Group. Odiyam Localities 1 and 2 (type). Karai Formation (Odiyam and Kunnam Members). Cenomanian. Uncommon.

\section{Subfamily Caestocorbulinae Vokes, 1945}

Genus Caestocorbula Vincent, 1910, sensu lato

\section{Type species}

Corbula henckeliusuana Nyst, 1836, by original designation. Eocene, Belgium.

\section{Remarks}

According to Vokes (1944), the genera Caestocorbula Vincent, 1910 and Parmicorbula Vokes, 1944 can be distinguised reliably only by reference to the siphonal plate located posteriorly on the right valve, a rarity in the fossil record and 


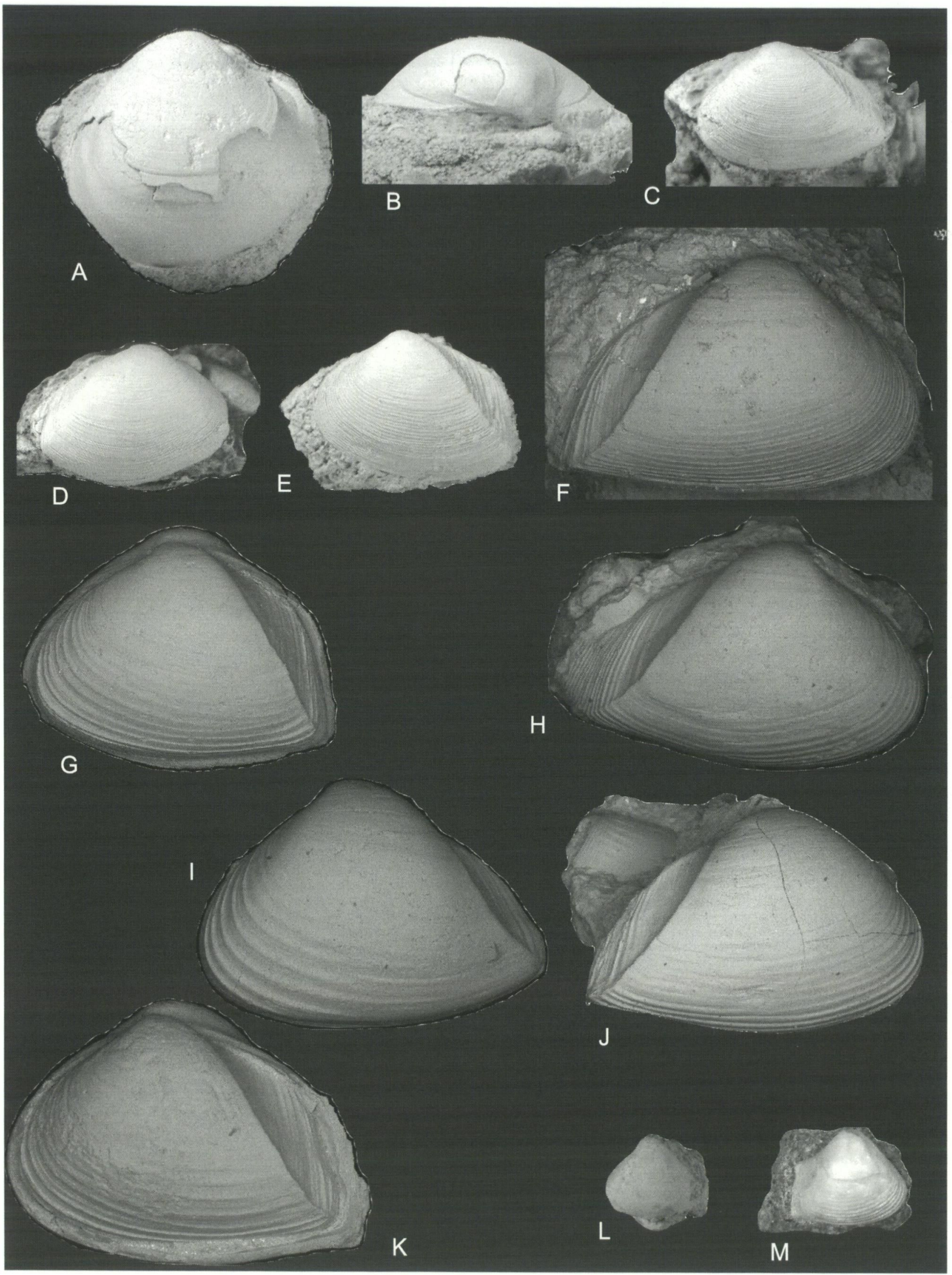

Figure 19 Mesocallista (M.?) sp. A ARI G2960/1, incomplete RV external x 2. B ARI G2960/2, LV dorsal aspect x 3. Caryocorbula cauveriensis sp. nov. C, ARI G2787/1, holotype, LV external x 4. D ARI G2787/2, paratype, RV external x 4. E ARI G2708, paratype, LV external x 6. Caryocorbula minima (d'Orbigny). F ARI G2720/2, RV external x 13. G ARI G2720/4, LV of conjoined pair x 17. H ARI G2795/1, RV external x 11.5. I ARI G2795/2, LV external x 14. J ARI G2795/10, RV external x 13. K ARI G2795/11, LV external of conjoined pair x 17. Caestocorbula kubera sp. nov. L ARI G2721/1, holotype, RV external x 8. M ARI G2721/4, paratype, LV external of conjoined pair $\times 8$. 
unknown from the present study material. In the adoption of the genus Caestocorbula sensu lato, we follow Squires and Saul (2004:120).

\section{Caestocorbula kubera sp. nov.}

Figure $19 \mathrm{~L}, \mathrm{M}$

\section{Material examined}

Holotype

ARI G2721/1, RV, from greyish-brown, ammonite-rich, quartzose calcarenite $c a 1.2 \mathrm{~km}$ west of Odiyam village, Perambalur Taluk, Tiruchirapalli district, Tamil Nadu (Locality 1).

\section{Paratypes}

ARI G2721/2-4, one LV, two RVs, from type locality. G2796, five RVs, Locality 2. Total of nine single valves.

\section{Diagnosis}

Minute, length to $5 \mathrm{~mm}$, longer than high, RV gibbous, commarginally rugose, posteriorly truncate to slightly extended; LV smaller, less inflated, smooth, posteriorly truncate.

\section{Description}

Minute, robust, valves markedly discrepant; RV larger, gibbous, enfolding LV along ventral margin; longer than high, plane of greatest length low; umbo strongly inflated, elevated; beak incurved, prosogyrate, anterior of centre; posterior area defined by rounded shoulder; antero-dorsal margin long, oblique, almost straight, curving abruptly into broadly arched ventral margin; postero-dorsal margin short, slightly concave, forming ca a right angle with antero-dorsal margin; posterior margin truncate to slightly extended; postero-ventral extremity slightly rostrate; ventral half sculptured with rugose, commarginal costellae of variable width, ca 11 in height of $2.5 \mathrm{~mm}$, much reduced on posterior area; apical area smooth; LV about as long as high, roundly triangular; inflated; beak incurved, prosogyrate; posterior area weakly defined by rounded shoulder; smooth overall; internal characters (both valves) obscured.

Dimensions of Caestocorbula kubera sp. nov.

\begin{tabular}{lccc}
\hline Specimens & Length & Height & Inflation \\
\hline ARI G2721/1, RV, holotype & 3.93 & 3.50 & 1.7 \\
ARI G2721/2, RV, paratype & 4.82 & 3.80 & 2.4 \\
ARI G2721/4, LV, paratype & 3.16 & 2.93 & 1.5 \\
ARI G2796/1, RV, paratype & 3.73 & 3.06 & 1.6 \\
ARI G2796/2, RV, paratype & 4.23 & 3.7 (est.) & 2.1
\end{tabular}

\section{Remarks}

The present species resembles and may be ancestral to "Corbula" parsura Stoliczka from the Trichinopoly Group of Garudamangalam (Stoliczka 1870: 44, pl. 1, figs 23, 24; pl. 16, figs 3, 4), probably Kulakkalnattam Formation (Turonian) and Valudavur Formation (Ariyalur Group, Maastrichtian) of Pondicherry (Kossmat 1897), differing in its more truncate RV posterior. The type material of $C$. parsura (GSI Stoliczka Collection 904, 905) comprises 12 small specimens, of which the largest, an RV-GSI 904, is here designated lectotype; dimensions are $5.39 \times 4.72 \times$ $2.3 \mathrm{~mm}$; all other specimens (GSI 905) are thereby paralectotypes. Of the congenor species from western N America, described by Squires and Saul (2004), the present species most resembles Caestocorbula aura Squires and Saul, from the Turonian of California. The Odiyam species recalls Corbula gaultina Pictet and Campiche but has fewer, stronger ribs (see Woods 1908: 214, pl. 34, figs 14-16).

\section{Etymology}

After Kubera, in the Hindu Pantheon, God of Wealth and guardian of Earth's treasures, depicted as an obese dwarf.

\section{Occurrence}

Uttattur Group. Odiyam Localities 1 (type) and 2. Karai Formation (Odiyam and Kunnam Members). Cenomanian. Rare.

\section{Subfamily Lentidiinae Vokes, 1945}

\section{Genus Lentidium Cristofori and Jan, 1832}

\section{Type species}

Lentidium maculatum Cristofori and Jan, 1832 (junior synonym of Tellina mediterranea Costa, 1829), by monotypy. Recent, Mediterranean.

\section{Subgenus Janschinella Merklin, 1961}

\section{Type species}

Lentidium (Janschinella) garetzkii Merklin, 1961. Oligocene, Eurasia.

\section{Lentidium (Janschinella) dissitum sp. nov. Figure $20 \mathrm{~A}, \mathrm{~B}$}

\section{Material examined}

\section{Holotype}

ARI G2790, LV, from brown calcareous siltstone with abundant turritellid gastropods, beside track ca $0.5 \mathrm{~km}$ west of Odiyam village, Perambalur Taluk, Tiruchirapalli district, Tamil Nadu (Locality 2). 
Paratypes

ARI G2962, two LVs, four RVs, from type locality. Total of seven single valves.

\section{Diagnosis}

Small for subgenus, length to $9 \mathrm{~mm}$, robust; valves discrepant, $R V$ higher relative to length and slightly more inflated than $L V ; R V$ ventral margin asymmetrically arched, lowest posteriorly, sinuate and incurved; LV ventral margin broadly arched, incurved.

\section{Description}

Small, robust, transversely sub-elliptical, tellinoid, short anteriorly, extended posteriorly; valves discrepant, RV higher relative to length and slightly more inflated than LV; umbo broad, low, slightly prosogyrate; beak incurved, prosogyrate, at anterior two fifths; lunule wanting; escutcheon narrowly lanceolate, short, shallow; posterior area (each valve) slightly concave, weakly defined by rounded shoulder; antero-ventral area without angulation; antero-dorsal margin short, almost straight, grading into well-rounded anterior margin; postero-dorsal margin longer, slightly convex; posterior margin roundly subtruncate; ventral margin (RV) asymmetrically arched, lowest posteriorly and sinuate; ventral margin (LV) broadly arched; ventral area (both valves) somewhat incurved; sculpture of faint to obscure, irregular growth striae, obsolete toward smooth beaks; chondrophore (LV) projecting; hinge and interiors obscured.

Dimensions of Lentidium (Janschinella) dissitum sp. nov.

\begin{tabular}{lccc}
\hline Specimens & Length & Height & Inflation \\
\hline ARI G2790, LV, holotype & 8.74 & 5.28 & 1.4 \\
ARI G2962/1, RV, paratype & 8.88 & 5.67 & 2.5 \\
ARI G2962/2, LV, paratype & 7.11 & 4.30 & 1.3 \\
\hline
\end{tabular}

\section{Remarks}

The subgenus Janschinella was erected (Merklin 1961) for three species of Lentidium from the Oligocene-Lower Miocene of the Aral Sea area to Western Europe and northern Paratethys. It is distinguished from Lentidium s. str. mainly by the anterior position of the beaks; some external resemblance to the genera Donax Linnaeus or Sphenia Turton is noted by Merklin (1961). The present species, the first of the genus and subgenus to be recorded from India and the Cretaceous, shares proportions with both $L$. (J) garetzkii and $L$. (J.) kuzhasaica Merklin but is distinct from each. It is smoother and shorter relative to height than $L$. (J.) garetzkii Merklin; shorter anteriorly than L. (J.) kuzhasaica Merklin. In outline, the Odiyam species is only slightly less elongate than Lentidium donaciformis (Nyst) from the Lower Oligocene
(Tongrian) of Belgium (Geys and Marquet 1983, pl. 27 , figs 1a, 1b).

\section{Etymology}

Latin dissitum (neuter), apart from, remote, from the type area.

\section{Occurrence}

Uttattur Group. Odiyam Locality 2. Karai Formation (Odiyam Member). Cenomanian. Rare.

\section{Superfamily Hiatelloidea Gray, 1824 \\ Family Hiatellidae Gray, 1824}

\section{Genus Hiatella Daudin in Bosc, 1801}

\section{Type species}

Hiatella monoptera Daudin in Bosc, 1801 (junior synonym of Mya arctica Linneaus, 1767), by subsequent designation of Winckworth (1932). Recent, northern seas.

\section{Hiatella tenella (Stoliczka, 1870) Figure $20 \mathrm{C}, \mathrm{D}$}

1870 Saxicava tenella Stoliczka: 88 , pl. 16 , figs 20 24.

1987 Hiatella tenella (Stoliczka); Tapaswi: 512. List only.

\section{Material examined}

GSI Stoliczka Collection 1139-1143, four LVs and six RVs from "north of Odium". ARI G2718, one LV and two RVs, Locality 1; G2794, 18 LVs and 29 RVs, Locality 2; G2926, two RVs, Locality 3. Total of 52 single valves, none complete.

\section{Diagnosis}

Small, length to $14 \mathrm{~mm}$, thin-shelled, transversely sub-elliptical, extended, tapered and subtruncate posteriorly; RV slightly more inflated; sculpture commarginal, very fine, obsolete apically.

\section{Description}

Small for genus, thin-shelled, fragile; subelliptical, short and rounded anteriorly, extended, tapered and subtruncate posteriorly; postero-dorsal area narrow, slightly concave, offset by low umbonal angulation; umbones broad, low, slightly prosogyrate, RV moderately inflated, gibbous, LV less so; beaks incurved, blunt, prosogyrate, at anterior third; lunule wanting; escutcheon narrow; sculpture of fine, irregular, often crowded commarginal growth striae and costellae, more prominent ventrally, obsolete toward beaks; occasional stepped growth pauses; hinge mostly obscured, cardinals double in RV, single in LV, 
according to Stoliczka (1870); from moulds, adductor scars lightly impressed, large, near extremities, above centre; pallial line obscure; one or two shallow internal grooves parallel to smooth ventral margin.

Dimensions of Hiatella tenella (Stoliczka).

\begin{tabular}{lccc}
\hline Specimens & Length & Height & Inflation \\
\hline GSI *, RV internal mould & $10.6+$ & 7.5 & - \\
ARI G2718/1, LV & 12.16 & 7.19 & 3.7 \\
ARI G2794/1, LV & 13.2 (est.) & 7.6 (est.) & 2.96 \\
ARI G2794/3, LV & 12.1 (est.) & 6.3 (est.) & 2.9 \\
ARI G2794/4, RV & 11.60 & 7.06 & 3.1 \\
ARI G2794/5, RV & 14.0 (est.) & 7.46 & 4.1 \\
ARI G2794/6, RV & 11.3 (est.) & 6.2 (est.) & 2.7 \\
\hline
\end{tabular}

* catalogue no. uncertain; incomplete posteriorly

\section{Remarks}

The type material of Saxicava tenella Stoliczka, from "north of Odium", is numbered 1139 to 1143 in the GSI Stoliczka Collection and according to the labels the specimens are those figured on his pl. 16, figs 20-24 respectively (published 1871). The figures depict perfect $L V$ and $R V$, internal and external and a conjoined pair. Examination of these specimens however shows that all present are either small or fragmentary or both, the largest being an RV internal mould. If these specimens are truly Stoliczka's type material or part of it, then it may be that the figures represent an idealised concept of the species, not depictions of actual specimens.

The study material, notably from Locality 2 where it is common, includes specimens of relatively large size. None retains an intact posterior margin, though the better specimens and moulds suggest a tapered, subtruncate extremity, unlike those of Stoliczka's figures. From the available material, the present species is much smaller than modern congenors; in Australian waters, these may attain a length exceeding $70 \mathrm{~mm}$.

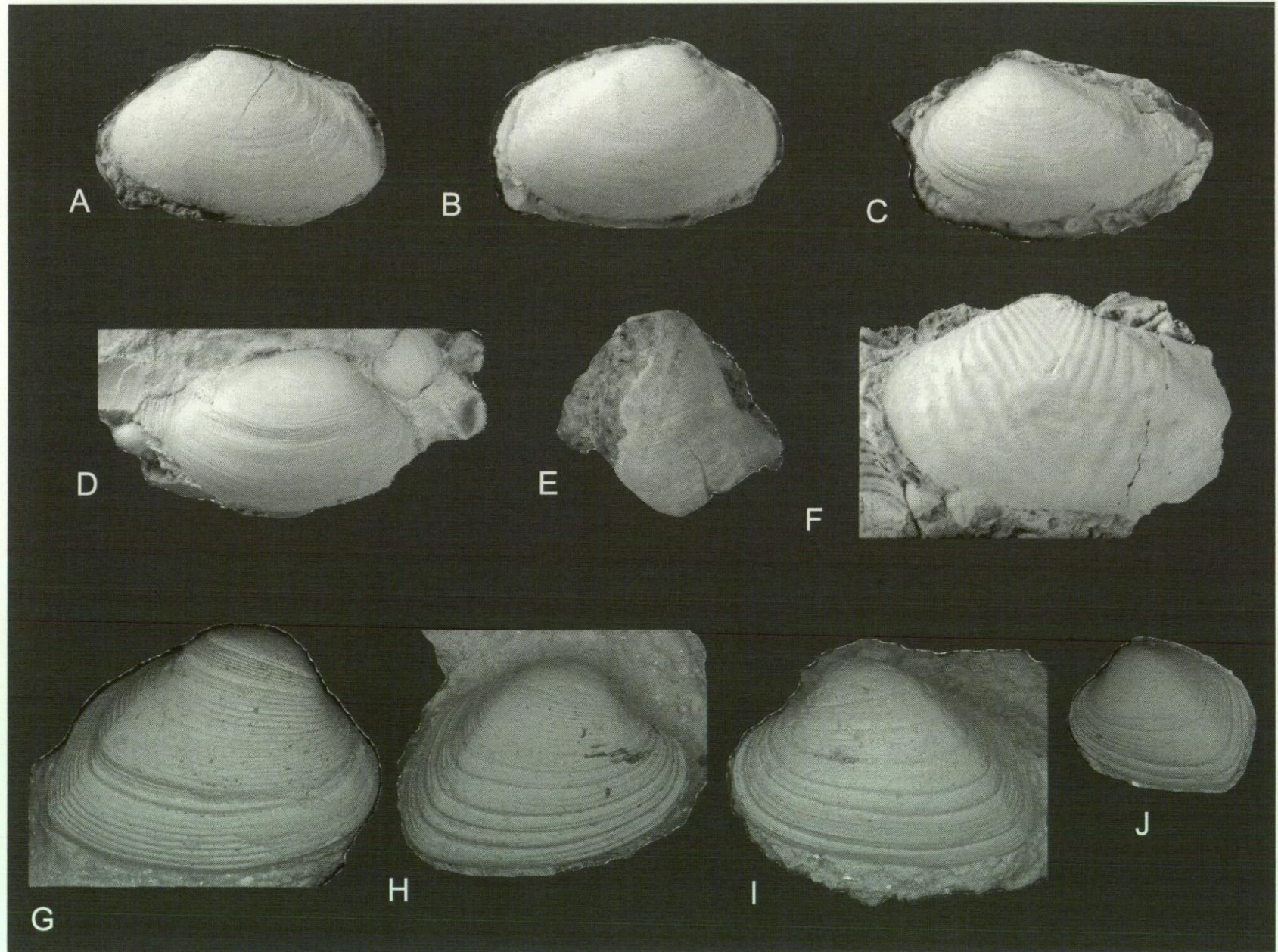

Figure 20 Lentidium (Janschinella) dissitum sp. nov. A ARI G2790, holotype, LV external x 4. B ARI G2962/1, paratype, RV external x 4. Hiatella tenella (Stoliczka). C ARI G2718/1, LV external x 3. D ARI G2794/4, RV external x 3. Xylophagella crassula (Stoliczka). E ARI G2798, part of small LV retaining median sulcus and commarginal costellae of posterior slope x 8. Goniomya sp. F ARI G4400/2, LV internal mould x 1.5. Barcoona ? gradilis sp. nov. G ARI G2722/1, holotype, RV external x 10. H ARI G2722/3, paratype, RV external x 10 . I ARI G2722/2, paratype, LVexternal x 10. J ARI G2722/4, paratype, LV external x 10. 


\section{Occurrence}

Uttattur Group. "North of Odium, not uncommon in a dark brown somewhat sandy limestone" (type). Odiyam Localities 1, 2 and 3. Karai Formation (Odiyam and Kunnam Members). Cenomanian.

\section{Superfamily Pholadoidea Lamarck, 1809}

Family Pholadidae Lamarck, 1809

\section{Subfamily Xylophagainae Purchon, 1941}

Genus Xylophagella Meek, 1864

\section{Type species}

Xylophaga elegantula Meek and Hayden, 1858, by original designation. Campanian. Montana.

\section{Xylophagella crassula (Stoliczka, 1870) Figure $20 \mathrm{E}$}

1870 Teredo crassula Stoliczka: 16, pl. 1, figs 2, 2a, $2 \mathrm{~b}$.

1987 Xylophaga crassula (Stoliczka); Tapaswi: 512. List only.

\section{Material examined}

Lectotype

Here designated. GSI Stoliczka Collection 883, conjoined pair from "Ootatoor", "in fossil wood impregnated with calcareous matter".

\section{Paralectotype}

GSI 883 , LV, from the type locality.

\section{Other material}

ARI G2719, LV, Odiyam Locality 1; G2798, LV, Odiyam Locality 2.

\section{Diagnosis}

Small, length to $11 \mathrm{~mm}$, globose; sculpture tripartite, commarginal on anterior slope and disc, obliquely sub-radial anterior to median sulcus; posterior slope smooth.

\section{Description}

Small, globose, thin-shelled; umbo gibbous, prosogyrate; anterior slope with narrow, commarginal costellae, crowded anteriorly to spaced medianly; disc with very fine, crowded, obliquely sub-radial costellae, terminating at prominent median radial sulcus; stronger commarginal costellae of uneven strength and spacing cross sulcus and onto posterior slope, becoming obsolete ventrally and on posterior extremity ("auricle"); posterior sulcus present on mould, corresponding to internal rib, separating disc from posterior slope.

Dimensions of Xylophagella crassula (Stoliczka).

\begin{tabular}{lccc}
\hline Specimens & Length & Height & Inflation \\
\hline $\begin{array}{c}\text { GSI Stoliczka Coll. 883, } \\
\text { pair, lectotype }\end{array}$ & ca 6 & ca 6 & ca $7.5^{*}$ \\
GSI Stoliczka Coll. 883, & ca 11 & ca10.5 & ca 7 \\
LV, paralectotype & & & \\
ARI G2719, LV & 5 (est.) & 4.7 (est.) & 2.1 (est.) \\
ARI G2798, LV & - & 7 (est.) & - \\
\hline
\end{tabular}

* valves gaping

\section{Remarks}

The genera of Mesozoic pholadids have been reviewed by Kelly (1988), who restricts the genus Xylophaga Turton, 1822 to Cenozoic forms. The latter are without exception wood-borers, according to Turner (2002). With a strong internal rib approximating to the disc-posterior slope transition, the present species is clearly to be located in the genus Xylophagella, which ranges possibly from Barremian or Early Albian to Maastrichtian (Kelly 1988).

The type material of Teredo crassula Stoliczka, GSI Stoliczka Collection nos 882 and 883 from "Ootatoor", comprises (a) 882, a piece of fossil wood measuring $90 \times 65 \times 55 \mathrm{~mm}$ penetrated by numerous shelly tubes, irregular in shape, circular in cross-section, rather thick, and variously orientated, up to $16 \mathrm{~mm}$ diameter; tube surfaces appear etched and lack regular transverse ridging. There is nothing to be seen on this specimen that would associate it directly with (b) specimens 883, comprising a pair of conjoined valves (lectotype) and a single, larger LV, neither complete. Comparison of ARI G2719 with the lectotype confirms their conspecificity.

Tubular borings in fossil wood attributed provisionally to the pholadid genus Opertochasma Stephenson, from log grounds within the Turonian Kulakkalnattam Formation are discussed by Hart et al. (1996 and references).

\section{Occurrence}

Uttattur Group. Uttattur (type). ? Dalmiapuram Formation. ? Albian. Odiyam Localities 1 and 2. Karai Formation (Odiyam and Kunnam Members). Cenomanian. Rare.

Subclass Anomalodesmata Dall, 1889

Order Pholadomyoida Newell, 1965

Superfamily Pholadomyoidea Gray, 1847 


\section{Family Pholadomyidae Gray, 1847}

\section{Genus Goniomya Agassiz, 1841}

\section{Type species}

Mya angulifera J. Sowerby, 1819 (junior synonym of Mya intersectans Smith, 1817), by subsequent designation of Hermannsen, 1847. Middle Jurassic. Europe.

\section{Subgenus Goniomya s. str \\ Goniomya (Goniomya) sp. Figure $20 \mathrm{~F}$}

\section{Material examined}

ARI G4400, LV, interior and separated internal mould and mould of beak, in brown calcareous siltstone with turritellid gastropods, beside track ca $0.5 \mathrm{~km}$ west of Odiyam village, Perambalur Taluk, Tiruchirapalli district, Tamil Nadu (Locality 2).

\section{Description}

Small (for genus), possibly immature LV, fragile, thin, longer than high, elliptical, moderately inflated; umbo broad, elevated, anterior of midline, orthogyrate with incurved beak; posterior area narrow, weakly defined by low radial shoulder; antero-dorsal margin near-straight; postero-dorsal margin slightly concave; anterior margin short, rounded; posterior margin longer, sub-truncate; ventral margin broadly convex, medially almost straight; lunule small; escutcheon wider, deeper, longer; both bordered by angulation; sculpture of steeply oblique, spaced, rounded costae, converging ventrally as chevrons about median line, subtending angle of $60^{\circ}$, becoming crowded toward beak; faint commarginal costellae cross chevron sculpture on part of median area, visible also on beak. External surface obscured; pallial line, adductor scars and hinge not apparent.

Dimensions of Goniomya (Goniomya) sp.

\begin{tabular}{lccc}
\hline Specimen & Length & Height & Inflation \\
\hline ARI G4400, LV & 33.5 & 19.9 & 8.3 (est.) \\
\hline
\end{tabular}

\section{Remarks}

The genus Goniomya was first recorded from the Cretaceous of south India by Ayyasami and Jagannatha Rao (1980) with specimens from "sandy limestone ... in the Peroniceras dravidicum Zone at about a kilometer west of Gudalur village $\left(11^{\circ} 08^{\prime} \mathrm{N}\right.$ : $\left.79^{\circ} 00^{\prime} \mathrm{E}\right)^{\prime \prime}$. This locality would appear to lie within the Coniacian Anaipadi Formation.

The present specimen, first record of the genus from the Karai Formation, differs appreciably from Goniomya (G.) stoliczkai Ayyasami and Jagannatha Rao in its more transverse- elliptical form (i.e., greater length relative to height), smaller size, weaker commarginal sculpture in the median area and absence of a radial rib and groove below the beak. It appears to be specifically distinct but the limited available material is unsuitable for type selection and formal naming. In size and proportions, the present species is not unlike $G$. (G.) subarchiaci Nagao from the Aptian-Albian of Japan, differing in its much weaker median-commarginal sculpture (Hayami 1966: 163-165, pl. 25, figs 1-13). Differs from the Goniomya spp. from the Upper Albian of Zululand in presence of weak commarginal sculpture in the median area (Newton 1909: 81-83, pl. 6, figs 18-21).

\section{Occurrence}

Uttattur Group. Odiyam Locality 2. Karai Formation (Odiyam Member). Cenomanian. Rare.

\section{Family undetermined}

Genus Barcoona Finlay, 1927

Pachydomella Etheridge Jnr, 1907, non Ulrich, 1891.

\section{Type species}

Pachydomella chutus Etheridge Jnr, 1907. AptianAlbian. Queensland.

\section{Barcoona? gradilis sp. nov.} Figure 20 G-J

\section{Material examined}

Holotype

ARI G2722/1, RV, from greyish-brown shelly calcarenite ca $1.2 \mathrm{~km}$ west of Odiyam village, Perambalur Taluk, Tiruchirapalli district, Tamil Nadu (Locality 1 ).

\section{Paratypes}

ARI G2722/2-31, six LVs, 24 RVs, from type locality. Total of 31 single valves.

\section{Other material}

ARI G2797, six LVs, 12 RVs, from Locality 2. Total of 18 single valves.

\section{Diagnosis}

Minute, length to $4.5 \mathrm{~mm}$, triangularly subovate, subtrigonal; RV only with single peg-like cardinal; LV apparently edentulous; escutcheon faint; resilium marginal, extended; sculpture commarginal, often gradate.

\section{Description}

Minute, robust, apparently equivalve, triangularly subovate, subtrigonal, longer than 
high; slightly inflated; posterior area well defined by subangulate, umbonal shoulder; umbones moderately inflated and elevated, prosogyrate; beaks incurved, strongly prosogyrate, at anterior third; lunule wanting; escutcheon faint, shallow, lanceolate, more apparent on LV and occupying entire postero-dorsal margin; resilifer (RV) extended, narrow, submarginal beneath escutcheon; antero-dorsal margin short, almost straight; postero-dorsal margin slightly convex, longer; anterior margin short, rounded; posterior margin obliquely truncate; ventral margin broadly arched, somewhat incurved (RV) on mature specimens; sculpture of fine, close, irregular, commarginal costellae of variable strength and spacing, finer and more crowded on posterior area, frequently stepped from growth pauses and becoming obsolete apically; beak smooth; RV with short, vertical, peg-like cardinal; LV apparently edentulous; from mould, adductor scars lightly impressed, anterior subcircular, at extremity; posterior larger, higher, below postero-dorsal angulation; pallial line a weak groove, entire, remote from margin; stronger commarginal groove between pallial line and margin; margin smooth, inner layer possibly subnacreous.

Dimensions of Barcoona? gradilis sp. nov.

\begin{tabular}{lccc}
\hline Specimens & Length & Height & Inflation \\
\hline ARI G2722/1, RV, holotype & 4.49 & 3.31 & 1.45 \\
ARI G2722/2, LV, paratype & 4.01 & 2.87 & 1.26 \\
ARI G2722/3, RV, paratype & 3.88 & 2.71 & 1.18 \\
ARI G2722/4, LV, paratype & 2.69 & 1.90 & 0.71 \\
\hline
\end{tabular}

\section{Remarks}

Variation noted in the study material concerns mainly the strength and spacing of the sculpture. Most specimens show several weak to strong growth-pause steps; several from Locality 2 lack these, being evenly and finely costellate across the disc. The escutcheon, at best faint, may or may not be a feature of both left and right valves. In the absence of conjoined pairs, there is some uncertainty as to whether the valves are truly equal or not, regarding sculpture, inflation and the conjunction of the ventral margins. The hinge appears to be discrepant but, due to its delicacy and the hardness of the sediment, has been exposed only partially on some of the paratypes. Four specimens show gastropod boreholes, a predation rate of $8.9 \%$

As noted above (p. 85), GSI Stoliczka Collection nos 900, 901, 902 and 903 comprise a mixed sample, mainly of "Corbula" minima d'Orbigny from "north of Odium". Two of the 20 specimens in this material are RVs of the present species but whether any of Stoliczka's (1870) figures depict these is not clear. However those shown on his plate 1, figs 19-
22 lack the posterior angulation so characteristic of d'Orbigny's species and may have been drawn from specimens of the present species.

The present, somewhat enigmatic species is assigned provisionally to the genus Barcoona Finlay, 1927, from a certain resemblance to the likewise enigmatic $B$. chutus (Etheridge Jnr) from the Aptian-Albian Tambo Series of Queensland, Australia (Etheridge 1907, Finlay 1927, Ludbrook 1966). The familial location(s) of these two species, possible congenors, remain(s) to be determined but it seems that a not-distant connection between them, at one level or another, may become recognised.

Odiyam specimens have been compared with Etheridge's type material of Barcoona chutus from the palaeontological collection of the Australian Museum, Sydney. This comprises five small specimens numbered AM F13704-F13707 and F13709, those figured on Etheridge's plate 62, figs $4-8$, and a small slab of grey, shelly, calcareous shale (measuring ca $200 \times 140 \times 40 \mathrm{~mm}$ ), with abundant, crowded, single valves of $B$. chutus, mostly convex side up, exposed on a naturally weathered bedding plane. This latter specimen was depicted on Etheridge's fig. 59. There being no holotype nominated, we here designate Australian Museum specimen F13704 to be lectotype of Barcoona chutus (Etheridge Jnr), figured on Etheridge's plate 62, fig. 4. Specimen AM F13704 (lectotype) is that figured by Cox in Moore (1969: N864, figs $\mathrm{H1}, 2$ ).

Comparison of the present (Odiyam) species with the Etheridge material of Barcoona chutus shows them to be not dissimilar, the latter attaining a greater size (length to $11 \mathrm{~mm}$ ). The Odiyam species has the beak located a little more anteriorly and there appears to be a short, peg-like cardinal on the RV; Etheridge considered his species to be edentulous. A small, weak escutcheon on the LV of the Odiyam species has no equivalent, so far as can be seen, on the Etheridge species; however, AM specimen F13707, the only conjoined pair of either species available for examination, shows the postero-dorsal margin of the RV transgressing over the corresponding area of the $L V$, which is the location of a weak escutcheon on the LV of the Odiyam species.

On the material presently available for both species, internal characters, including hinges, are poorly indicated and there is no means at present to establish satisfactorily the precise relationship of the two. The need for further, better preserved material from both sources is indicated. Ludbrook's (1966) location of B. chutus in the synonymy of "Mactra" trigonalis Moore seems questionable, in view of the presence in that species of lateral and other mactroid (?) dentition (Moore 1870: 252, pl. 14, fig. 6). 


\section{Etymology}

Latin gradilis (fem.), stepped; from the sculpture.

\section{Occurrence}

Uttattur Group. Odiyam Localities 1 (type) and 2. Karai Formation (Odiyam and Kunnam Members). Cenomanian.

\section{ACKNOWLEDGEMENTS}

To Dr A.D. Agate, Director, Agharkar Research Institute (ARI), Pune, we acknowledge with thanks access to the Institute's facilities and study materials, field support and (for G.W.K.) accommodation whilst in Pune.

Dr R. M. Badve and Dr C. Rajshekar, Heads of Department of Geology and Palaeontology, ARI, provided generous and cordial assistance with laboratory and field work and with the provision of published literature. Dr Badve, in particular, gave freely of his extensive knowledge of Indian Cretaceous palaeontology. Without his encouragement and support, this study would never have been attempted.

Dr T.C. Lahiri, Director of Palaeontology, Geological Survey of India, Kolkata and Dr S. Sen Gupta, Central Palaeontological Repository, provided access to the Stoliczka Collection. Mrs B. Guha kindly assisted with literature.

We are greatly obliged to Dr K. Ayyasami, GSI Regional Palaeontological Laboratories, Bandlaguda via Hyderabad, for sharing his extensive stratigraphic knowledge of the Cauvery Basin and for assistance with literature.

To the Dalmia Cement Company we express appreciation for the use of valued accommodation whilst in the field.
For assistance with literature and access to comparative material in their care, we have to thank Dr A.V. Dhondt, Koninklijk Belgisch Instituut voor Natuurwetenschappen, Brussels; Dr N. Morris, The Natural History Museum, London and Professor A. Lauriat-Rage, Muséum national d'Histoire naturelle, Paris.

For biostratigraphic, taxonomic and other advice, our thanks are due to Professor R.A. Henderson, James Cook University, Townsville; to Professor J.A. Grant-Mackie, The University of Auckland and to Drs A.G. Beu and J.S. Crampton, both of Institute of Geological and Nuclear Sciences, New Zealand. Responsibility for all taxonomic formulations proposed herein lies with the authors.

For contributions to the photographic illustration of the study material, we are greatly obliged to Miss Kristine Brimmell (Western Australian Museum), Miss Karen Edward (who also prepared the map) and $\mathrm{Mr}$ Dennis Sarson (University of Western Australia); to Associate Professor David W. Haig and $\mathrm{Mr} \mathrm{D}$. Ostrognay (UWA) for SEM photography and to Mrs Susan Tingay for most faithfully executed line drawings.

Photographs of Forbes' Trigonarca type material were kindly provided by Dr N. Morris, The Natural History Museum, London. For photographs of the type specimen of Profragum praecurrens (Stoliczka), we have to thank Dr S. Sen Gupta, Geological Survey of India, Kolkata.

The map and caption of Figure 1 are reproduced from Sundaram et al. (2001, fig. 3), with permission from Elsevier.

Mrs A. Nevin and Miss M. Tarling typed the manuscript. 
Appendix

Bivalvia from the Karai Formation, Odiyam: order of abundance in the study material, by localities (1-3). Asterisk denotes type locality. Localities 1 and 3 represent Kunnam Member; Locality 2 represents Odiyam Member.

\begin{tabular}{|c|c|c|c|c|c|}
\hline \multirow{3}{*}{\multicolumn{2}{|c|}{ Species }} & \multicolumn{4}{|c|}{ No. specimens } \\
\hline & & \multicolumn{3}{|c|}{ Localities } & \multirow[b]{2}{*}{ Totals } \\
\hline & & 1 & 2 & 3 & \\
\hline 1. & Paramyrtea sabulosa gen. nov., sp. nov. & $421^{*}$ & 11 & 13 & 445 \\
\hline 2. & Caryocorbula minima (d'Orbigny). & 150 & 98 & 9 & 257 \\
\hline 3. & Aphrodina (A.) plebeia sp. nov. & 32 & $208^{*}$ & - & 240 \\
\hline 4. & Nuculana (N.) odiyamensis sp. nov. & 14 & $180^{*}$ & - & 194 \\
\hline 5. & Grammatodon (Nanonavis) subcrenulatus sp. nov. & 34 & $111^{*}$ & 4 & 149 \\
\hline 6. & Limopsis coemansi Briart and Cornet. & 40 & 27 & 3 & 70 \\
\hline 7. & Nucula (N.) bidorsata Stoliczka. & 3 & 54 & 5 & 62 \\
\hline 8. & Nemodon (N.) filistriata (Stoliczka). & 13 & 27 & 17 & 57 \\
\hline 9. & Hiatella tenella (Stoliczka). & 3 & 47 & 2 & 52 \\
\hline 10. & Barcoona? gradilis sp. nov. & $31^{*}$ & 18 & - & 49 \\
\hline 11. & Parvamussium sp. & 46 & 2 & - & 48 \\
\hline 12. & Atreta redunca sp. nov. & 11 & $28^{*}$ & 3 & 42 \\
\hline 13. & Syncyclonema? sp. & 15 & 8 & 15 & 38 \\
\hline 14. & Mesomiltha? sp. & 19 & 13 & 6 & 38 \\
\hline 15. & Mesocallista (M.) vagrans (Stoliczka). & 3 & 8 & 22 & 33 \\
\hline 16. & Nuculana (N.) arenicola sp. nov. & 15 & $8^{*}$ & 6 & 29 \\
\hline 17. & Callucinella marcida sp. nov. & - & $24^{*}$ & - & 23 \\
\hline 18. & Mesomiltha sp. cf. M. fallax (Forbes) & 7 & 16 & - & 23 \\
\hline 19. & Trigonarca (Costelliarca) punctulata sp. nov. & 6 & $5^{*}$ & 11 & 22 \\
\hline 20. & Pycnodonte vesiculosa (J. Sowerby). & 4 & 4 & 13 & 21 \\
\hline 21. & Goodallia salebrosa sp. nov. & - & $19^{*}$ & - & 19 \\
\hline 22. & Goodallia? australindica sp. nov. & - & 2 & $16^{*}$ & 18 \\
\hline 23. & Trigonarca (Costelliarca) gamana (Forbes). & - & 6 & 10 & 16 \\
\hline 24. & Aphiodina (A.) fabulina (Stoliczka). & - & - & 15 & 15 \\
\hline 25. & Pratulum scrobiculatum (Stoliczka). & 10 & 2 & 2 & 14 \\
\hline 26. & Limopsis sp. A. & 8 & 5 & - & 13 \\
\hline 27. & Leionucula sp. cf. L. albensis (d'Orbigny). & 4 & 5 & 3 & 12 \\
\hline 28. & Trigonarca (Costelliarca) trichinopolitensis (Forbes). & - & 4 & 8 & 12 \\
\hline 29. & Callucinopsis? dalmiana sp. nov. & - & - & $12^{*}$ & 12 \\
\hline 30. & Neithea (N.) quinquecostata (J. Sowerby). & 7 & 4 & - & 11 \\
\hline 31. & Mesocallista (M.) sp. cf. M. (M.) analoga (Forbes). & 2 & 4 & 5 & 11 \\
\hline 32. & Caryocorbula cauveriensis sp. nov. & 3 & $8^{*}$ & - & 11 \\
\hline 33. & Limatula persimilis (Stoliczka). & 4 & 4 & 2 & 10 \\
\hline 34. & Profragum praecurrens (Stoliczka). & - & 1 & 9 & 10 \\
\hline 35. & Aenona ? ariana sp. nov. & 9 & $1^{*}$ & - & 10 \\
\hline 36. & Glycymerita (G.) cardioides (d'Orbigny). & 2 & 7 & - & 9 \\
\hline 37. & Linearia sp. & - & 6 & 3 & 9 \\
\hline 38. & Caestocorbula kubera sp. nov. & $4^{*}$ & 5 & - & 9 \\
\hline 39. & Noetiid, genus and species undetermined & - & - & 9 & 9 \\
\hline 40. & Plicatula (Darteplicatula) sessilis Stoliczka. & - & 7 & 1 & 8 \\
\hline 41. & Lucinid, genus undetermined, species B. & - & - & 8 & 8 \\
\hline 42. & Eriphyla (Miyakoella) badvei sp. nov. & - & $8^{*}$ & - & 8 \\
\hline 43. & Anthonya sp. & - & 5 & 1 & 6 \\
\hline 44. & Lentidium (Janschinella) dissitum sp. nov. & - & $7^{*}$ & - & 7 \\
\hline 45. & Neithea (N.) pseudobellula Chiplonkar and Tapaswi & - & 5 & 1 & 6 \\
\hline 46. & Mesocallista (M.?) sp. & 4 & - & 2 & 6 \\
\hline 47. & Neithea (N.) sp.cf. N. (N.) hispanica (d'Orbigny) & - & - & 5 & 5 \\
\hline 48. & Protocardia (P.) alta (Sowerby in Forbes). & - & - & 4 & 4 \\
\hline 49. & Neithea (N.) aequicostata (Lamarck). & - & 3 & - & 3 \\
\hline 50. & Lucinid, genus undetermined, Species A. & 2 & - & 1 & 3 \\
\hline 51. & Fimbria sp. & 1 & 2 & - & 3 \\
\hline
\end{tabular}


Appendix (cont.)

\begin{tabular}{|c|c|c|c|c|c|}
\hline \multirow{2}{*}{\multicolumn{2}{|c|}{ Species }} & \multicolumn{4}{|c|}{ No. specimens } \\
\hline & & 1 & 2 & 3 & Totals \\
\hline 52. & Limopsis sp. B. & 1 & 1 & - & 2 \\
\hline 53. & Xylophagella crassula (Stoliczka). & 1 & 1 & - & 2 \\
\hline 54. & Neithea (N.) gibbosa (R. Pulteney). & - & - & 1 & 1 \\
\hline 55. & Nippononectes sp. & 1 & - & - & 1 \\
\hline 56. & Pinna sp. & 1 & - & - & 1 \\
\hline 57. & Inoceramus (I.) pictus J. Sowerby. & - & - & 1 & 1 \\
\hline 58. & Atreta sp. & - & - & 1 & 1 \\
\hline 59. & Plagiostoma ootatoorensis (Stoliczka). & - & - & 1 & 1 \\
\hline \multirow[t]{2}{*}{60.} & Goniomya (G.) sp. & - & 1 & - & 1 \\
\hline & Totals & 931 & 1020 & 252 & 2203 \\
\hline
\end{tabular}




\section{REFERENCES}

Afshar, F. (1969). Superspecific groups of Cretaceous and Cenozoic Tellinidae. Geological Society of America Memoir 119: 1-215.

Ayyasami, K. (1990). Cretaceous heteromorph ammonoid biostratigraphy of southern India. Newsletters on Stratigraphy 22: 111-118.

Ayyasami, K. and Banerji, R.K. (1984). CenomanianTuronian transition in the Cretaceous of South India. Bulletin of the Geological Society of Denmark 33: 2130.

Ayyasami, K. and Jagannatha Rao, B.R. (1979). On the distribution of Utatur and Trichinopoly rocks around Kallakkudi (Dalmiapuram), Tiruchirapalli district, Tamil Nadu. Indian Minerals 33: 45-48.

Ayyasami, K. and Jagannatha Rao, B.R. (1980). Goniomya from Trichinopoly Group, Upper Cretaceous, Tamil Nadu. Journal of the Geological Society of India 21: 354-357.

Aziz, S.A. (1985). Palaeontological studies of brachiopod and echinoid fauna from the South Indian Cretaceous deposits, Tamil Nadu. Unpublished Ph.D. thesis, The University of Poona.

Badve, R.M. (1977). Profraginae, a new Cardiid subfamily from the Upper Cretaceous rock formations of South India. Biovigyanam 3: 61-64.

Banerji, R.K. (1973). Stratigraphy and micropalaeontology of the Cauvery Basin. Part 1. Exposed area. Journal of the Palaeontological Society of India 17: 7-30.

Barron, E.J. (1987). Global Cretaceous palaeogeography International Geologic Correlation Program Project 191. Palaeogeography, Palaeoclimatology, Palaeoecology 59: 207-214.

Beu, A.G. and Maxwell, P.A. (1990). Cenozoic Mollusca of New Zealand. New Zealand Geological Survey Palaeontological Bulletin 58.

Bhatia, S.B. and Jain, S.P. (1969). Dalmiapuram Formation: a new Lower Cretaceous horizon in South India. Bulletin of the Indian Geologists' Association 2: 105-108.

Bhattacharya, A. and Bhattacharya, U. (1987). Review of the stratigraphy and palaeontology of Upper Cretaceous sediments of northeastern India. Geological Survey of India Special Publication 11: 367-387.

Blanford, H.F. (1862). On the Cretaceous and other rocks of the South Arcot and Trichinopoly districts, Madras. Palaeontologica Indica. Memoirs of the Geological Survey of India IV: 1-217.

Briart, A. and Cornet, F.-L. (1868). Description minérologique, géologique et paléontologique de la Meule de Bracquegnies. Mémoires couronés et mémoires des savants étrangers publiés par $L$ 'Académie royale de Belgique 34.

Carter, J.G. (1990). Evolutionary significance of shell microstructure in the Palaeotaxodonta, Pteriomorphia and Isofilibranchia (Bivalvia: Mollusca), 135-296. In Carter, J.G. (ed.). Skeletal biomineralisation: patterns, processes and evolutionary trends, Vol. 1. Van Nostrand Reinhold, New York, vii $+832 \mathrm{p}$.

Chiplonkar, G.W. (1987). Three decades of invertebrate palaeontology and biostratigraphy of marine Cretaceous rocks of India. Three decades of developments in palaeontology and stratigraphy in India. Vol. 1. (Precambrian to Mesozoic). Geological Survey of India Special Publication 11: 305-339.

Chiplonkar, G.W. and Badve, R.M. (1973). Palaeontology of the Bagh Beds - I - Bivalvia (excluding Inoceramidae and Ostreacea). Journal of the Palaeontological Society of India 17: 67-114.

Chiplonkar, G.W. and Badve, R.M. (1976). Palaeontology of the Bagh Beds - IV - Inoceramidae. Journal of the Palaeontological Society of India 18: 1-12.

Chiplonkar, G.W. and Joshi, D.A. (1976). On Neithea morrisi (Pictet and Renevier, 1858). Journal of the University of Poona (Science and Technology Section) 48: $127-131$.

Chiplonkar, G.W. and Tapaswi, P.M. (1973). Emendation of the bivalve genus Trigonarca Conrad, 1862. Current Science 42: 653.

Chiplonkar, G.W. and Tapaswi, P.M. (1974). Bivalvia from the Upper Cretaceous of Trichinopoly district, South India. Part 1 - Inoceramidae. Recent researches in Geology 3: 87-123.

Chiplonkar, G.W. and Tapaswi, P.M. (1975a). Biostratigraphy of the inoceramids in the Upper Cretaceous of Trichinopoly District, South India. Biovigyanam 1: 11-15.

Chiplonkar, G.W. and Tapaswi, P.M. (1975b). New Pterioid bivalves (excluding Inoceramidae) from the Upper Cretaceous rocks of Trichinopoly District, South India. Biovigyanam 1: 131-148.

Chiplonkar, G.W. and Tapaswi, P.M. (1975C). Trichiplicatula, a new plicatulid subgenus from the Upper Cretaceous of Trichinopoly dist., S. India. Biovigyanam 1: 95-96.

Chiplonkar, G.W. and Tapaswi, P.M. (1976a). Arcoids and Mytiloids (Bivalvia) from the Upper Cretaceous of Trichinopoly District, South India. Chayanica Geologica 2: 215-232.

Chiplonkar, G.W. and Tapaswi, P.M. (1976b). Bivalvia from the Upper Cretaceous of Trichinopoly District, South India. Part - 1: Inoceramidae. A collection of papers in honour of Professor I.C. Pande, F.N.A. Recent Researches in Geology 3: 87-123.

Chiplonkar, G.W. and Tapaswi, P.M. (1976c). Nomenclatural comments on some Inoceramid species from the Upper Cretaceous rocks of South India. Journal of Poona University (Science and Technology Section) 48: 139-147.

Chiplonkar, G.W. and Tapaswi, P.M. (1977a). Comments on some arcoid and mytiloid bivalves from the Upper Cretaceous of Trichinopoly District, S. India. Journal of Poona University (Science and Technology Section) 50: $15-24$

Chiplonkar, G.W. and Tapaswi, P.M. (1977b). Comments on some Pterioids (excluding Inoceramids and Ostreiids), Veneroids and Pholadomyids from the Upper Cretaceous of Trichinopoly district, South India. Journal of Poona University (Science and Technology Section) 50: 1-99-208.

Chiplonkar, G.W. and Tapaswi, P.M. (1979). Biostratigraphy, age and affinities of the bivalve fauna of the Cretaceous of Tiruchirapalli district, south India. Geological Survey of India Miscellaneous Publication 45: 137-164. 
Collignon, M. (1949). Le Crétacé supérieur d'Antonibe. Couches de passage du Crétacé au Tertiaire. Annales Géologiques du Services des Mines, Madagascar 19.

Collignon, M. (1968). Le Crétacé supérieur de Madagascar. In Cretaceous - Tertiary formations of India. Memoirs of the Geological Society of India. 2: 320-334.

Cox, L.R. (1935). The Triassic, Jurassic and Cretaceous Gastropoda and Lamellibranchia of the Attock District. Memoirs of the Geological Survey of India. Palaeontologica Indica N.S. 20, 5: 1-27, pls 1,2.

Cox, L.R. (1964). Notes concerning the taxonomy and nomenclature of fossil Bivalvia (mainly Mesozoic). Proceedings of the Malacological Society of London 36: 39-48, 1 plate.

Cox, L.R. and Hertlein, L.G. (1969). Family Plicatulidae Watson, 1930. In R.C. Moore, editor. Treatise on Invertebrate Paleontology N. Mollusca 6, vol. 1: N377-N378.

Crame, J.A. (1981). Upper Cretaceous inoceramids (Bivalvia) from James Ross Island Group and their stratigraphical significance. British Antarctic Survey Bulletin 53: 29-56.

Darragh, T.A. and Kendrick, G.W. (1991). Maastrichtian Bivalvia (excluding Inoceramidae) from the Miria Formation, Carnarvon Basin, north western Australia. Records of the Western Australian Museum Supplement 36: 1-102.

Dartevelle, E. and Freneix, S. (1957). Mollusques fossiles du Crétacé de la côte occidentale d'Afrique, du Cameroun à l'Angola. II - Lamellibranches. Annales du Museé Royal du Congo Belge, Tervuren (Belgique) 20: 1-271.

De Cauwer, G. (1985). Gastropod predation on corbulid bivalves: palaeoecology or taphonomy? Annales Societe Royale Zoologique de Belgique 115: 183-196.

Dhondt, A.V. (1971). Systematic revision of Entolium, Propeamussium (Amusiidae) and Syncyclonema (Pectinidae, Bivalvia, Mollusca) of the European Boreal Cretaceous. Institut Royal des Sciences Naturelles de Belgique Bulletin 47: 1-95.

Dhondt, A.V. (1973). Systematic revision of the subfamily Neitheinae (Pectinidae, Bivalvia, Mollusca) of the European Cretaceous. Institut Royal des Sciences Naturelles de Belgique Mémoire 176: 1-101.

Dhondt, A.V. (1992). Cretaceous inoceramid biogeography: a review. Palaeogeography, Palaeoclimatology, Palaeoecology 92: 217-232.

Dhondt, A.V. and Dieni, I. (1993). Non-rudist bivalves from Late Cretaceous rudist limestones of NE Italy (Col dei Schiasi and Lago di S. Croce areas). Memoire di Scienze Geologiche 45: 165-241.

Dijkstra, H.H. (1995). Bathyal Pectinoidea (Bivalvia: Propeamussiidae, Entoliidae, Pectinidae) from New Caledonia and adjacent areas, in Résultats des Campagnes MUSORSTOM, vol. 14. P. Bouchet (ed.). Mémoires du Muséum national d'Histoire naturelle, Zoologie 167: 9-73.

Etheridge, R. (1907). Lower Cretaceous fossils from the sources of the Barcoo, Ward and Nive Rivers, south central Queensland. Records of the Australian Museum 2: 317-329.

Feldtmann, F.R. (1963). Some pelecypods from the
Cretaceous Gingin Chalk, Western Australia, together with descriptions of the principal Chalk exposures. Journal of the Royal Society of Western Australia 46: 101-125.

Finlay, H.J. (1927). New specific names for Austral Mollusca. Transactions of the New Zealand Institute 57: 488-533.

Fleming, C.A. (1978). The bivalve mollusc genus Limatula: A list of described species and a review of living and fossil species in the Southwest Pacific. Journal of the Royal Society of New Zealand 8: 17-91.

Forbes, E. (1846). Report on the fossil invertebrates from Southern India, collected by $\mathrm{Mr}$ Kaye and $\mathrm{Mr}$ Cunliffe. Transactions of the Geological Society of London 7: 97-174.

Freneix, S. (1956). Lamellibranches crétacés du BasCongo récoltes par $\mathrm{H}$. Pierard. Annalen du Museé Royal du Congo Belge 17: 96-120.

Freneix, S. (1957). Observations nouvelles sur la faune crétacé de lamellibranches des différentes sédimentaires du Cameroun. Comptes Rendus $d u$ Congrès des Sociétés Savantes de Paris et des Départements, 1957: 75-101.

Freneix, S. (1958). Contribution à l'étude des Lamellibranches du Crétacé de Nouvelle-Calédonie. Sciences de la Terre 4: 153-207.

Fürsich, F.T. and Pandey, D.K. (1999). Genesis and environmental significance of Upper Cretaceous shell concentrations from the Cauvery Basin, southern India. Palaeogeography, Palaeoclimatology, Palaeoecology 145: 119-139.

Fürsich, F.T. and Werner, W. (1988). The Upper Jurassic Bivalvia of Portugal. Part II. Pteriomorpha (Pterioida exclusive Ostreina). Comunicacões dos Serviços Geológicos de Portugal 74: 105-164.

Gale, A.S., Hardenbol, J., Hathway, B., Kennedy, W.J., Young, J.R. and Phansalkar, V. (2002). Global correlation of Cenomanian (Upper Cretaceous) sequences: Evidence for Milankovich control on sea level. Geology 30: 291-294.

Geys, J.F. and Marquet, R. (1983). Field atlas on Cenozoic fossils of Belgium. Part 2, Paleogene. Publicatie van de Belgische Vereniging voor Paleontologie 3: 1-203.

Giribet, G. and Peñas, A. (1999). Revision of the genus Goodallia (Bivalvia: Astartidae) with the description of two new species. Journal of Molluscan Studies 65: 251-265.

Grönwall, K.A. (1906). Dimyodon in British Mesozoic rocks. Geological Magazine (N.S.) Decade V, 3: 202205.

Hancock, J.M. (2000). Late Cretaceous eustatic highs. In A. Govindan (Ed.). Cretaceous stratigraphy. An update. Geological Society of India Memoir 46: 1-14.

Haq, B., Hardenbol, J. and Vail, P.R. (1987). Chronology of fluctuating sea levels since the Triassic. Science 235: 1156-1167.

Harper, E.M. and Peck, L. (2003). Predatory behavior and metabolic costs in the Antarctic muricid gastropod Trophon longstaffi. Polar Biology 26: 208-217.

Hart, M.B., Tewari, A. and Watkinson, M.P. (1996). Wood-boring bivalves from the Trichinopoly Sandstone of the Cauvery Basin, South-East India. In J. Pandey, R.J. Azmi, A. Bhandari and A. Dave (Eds.). 
XVth Indian Colloquium on Micropalaeontology and Stratigraphy: 529-539.

Hautmann, M. (2001). Taxonomy and phylogeny of cementing Triassic bivalves (families Prospondylidae, Plicatulidae, Dimyidae and Ostreidae). Palaeontology 44: 339-373.

Hayami, I. (1965a). Lower Cretaceous marine pelecypods of Japan. Part 1. Memoirs of the Faculty of Science, Kyushu University. Series D. Geology 15: 221-349.

Hayami, I. (1965b). Lower Cretaceous marine pelecypods of Japan. Part 2. Memoirs of the Faculty of Science, Kyushu University. Series D. Geology 17: 73-150.

Hayami, I. (1966). Lower Cretaceous marine pelecypods of Japan. Part 3. Memoirs of the Faculty of Science, Kyushu University. Series D. Geology 17: 151-249.

Heinberg, C. (1979). Bivalves from the Whitechalk (Maastrichtian) of Denmark II: Arcoida. Bulletin of the Geological Society of Denmark 27: 105-116.

Heinz, R. (1933). Inoceramen von Madagaskar und ihre Bedeutung für die Kreide-Stratigraphie. Zeitschrift der Deutschen Geologischen Gesellschaft 85: 241-304.

Hodges, P. (1991). The relationship of the Mesozoic bivalve Atreta to the Dimyidae. Palaeontology 34: 963-970

International Commission on Zoological Nomenclature. (1999). International Code of Zoological Nomenclature. Fourth Edition, 306 pp. ICZN, London.

Janssen, A.W. (1984). Mollusken uit het Mioceen van Winterswijk-Miste. Koninklijke Nederlandse Naturrhistorische Vereniging. Uitgave nr 36: 1-451.

Johnson, A.L.A. (1984). The palaeobiology of the bivalve families Pectinidae and Propeamussiidae in the Jurassic of Europe. Zitteliana 11: 1-235.

Johnston, P.A. and Collom, C.J. (1998). The bivalve heresies - Inoceramidae are Cryptodonta, not Pteriomorpha. Bivalves: An Eon of evolution paleobiological studies honoring Norman $D$. Newell (eds P.A. Johnston and J.W. Haggart) University of Calgary Press, Calgary: 347-360.

Kabat, A.R. (1990). Predatory ecology of naticid gastropods with a review of shell boring predation. Malacologia 32: 155-193.

Kanji Lal, S. (1996). Thoughts on Plicatula Lamarck (Pectinacea: Bivalvia). Journal of the Palaeontological Society of India 41: 139-143.

Kauffmann, E.G. (1973). Cretaceous Bivalvia. In A. Hallam, Editor. Atlas of palaeobiogeography. Elsevier, Amsterdam, London, New York: 353-383

Kawaguti, S. (1950). Observations on the heart shell Corculum cardissa (Linnaeus) and its associated zooxanthellae. Pacific Science 4: 43-49.

Keen, A.M. (1980). The pelecypod family Cardiidae: a taxonomic summary. Tulane Studies in Geology and Paleontology 16: $1-44$.

Kelly, S.R.A. (1988). Cretaceous wood-boring bivalves from Western Antarctica with a review of the Mesozoic Pholadidae. Palaeontology 31: 341-372.

Kilburn, R.N. (1983). The Recent Arcidae (Mollusca: Bivalvia) of southern Africa and Mozambique. Annals of the Natal Museum 25: 511-548.

Kossmat, F. (1895). Untersuchungen uber die Südindische Kreideformation. Beiträge zur
Paläontologie Österreich-Ungarns und des Orients 9: 97-203.

Kossmat, F. (1897). Untersuchungen uber die Südindische Kreideformation. Beiträge zur Paläontologie Österreich-Ungarns und des Orients 11: $1-46$

Kossmat, F. (1897). The Cretaceous deposits of Pondicherri. Records of the Geological Survey of India 30: 51-111.

Kossmat, F. (1898). Untersuchungen uber die Südindische Kreideformation. Beiträge zur Paläontologie Österreich-Ungarns und des Orients 11: 89-152.

Lakshminarayana, K.V., Subba Rao, N.V. and Saha, U. (1976). Notes on the fossil Pinna (Pinnidae: Pelecypoda: Mollusca) from Trichinopoly Cretaceous, South India, with a key to the identification of species. Records of the Zoological Survey of India 71: 175-181, 3 plates.

Lamarck, J.B. de (1815-1822). Histoire naturelle des animaux sans vertèbres. Bivalvia 1818, 5: 424-612; 1819, 6: 1-233.

Ludbrook, N.H. (1966). Cretaceous biostratigraphy of the Great Artesian Basin in South Australia. Geological Survey of South Australia Bulletin 40: 1-223.

Malchus, N. (2000). Early shell stages of the Middle Jurassic bivalves Camptochlamys (Pectinidae) and Atreta (Dimyidae) from Poland. Journal of Molluscan Studies 66: 577-581.

Marlière, R. (1939). La transgression albienne et cénomanienne dans le Hainault. Mémoires du Musée royale d'Histoire naturelle de Belgique. 89: 1-440.

Matsumoto, M. and Hayami, I. (2000). Phylogenetic analysis of the family Pectinidae (Bivalvia) based on mitochondrial cytochrome $\mathrm{C}$ oxidase subunit I. Journal of Molluscan Studies 66: 477-488.

McNamara, K.J., Friend, D. and Long, J.A. (1993). A guide to the fossils of the Gingin Chalk. Perth, Western Australian Museum. Second revised edition: $1-16$.

Merklin, R.L. (1961). A new Tertiary corbulid genus. Paleontological Journal 1: 82-88. [In Russian].

Monari, S. (2003). A new genus and species of fimbriid bivalve from the Kimmeridgian of the Western Pontides, Turkey, and the phylogeny of the Jurassic Fimbriidae. Palaeontology 45: 857-884, 1 plate.

Mongin, D. (1979). Observations paléoecologiques et biogéographiques sur les gastéropodes et lamellibranches du stratotype de l'Albien. In, l'Albien de l'Aube. Les stratotypes français. 5: 407-429.

Moore, C. (1870). Australian Mesozoic geology and palaeontology. Geological Society of London Quarterly Journal 26: 226-261

Moore, R.C. (Editor). (1969). Treatise on invertebrate paleontology N. Mollusca 6: N1-N951.

Narayanan, V. (1977). Biozonation of the Utatur Group, Trichinopoly, Cauvery Basin. Journal of the Geological Society of India 18: 415 428.

Nayak, K.K. and Badve, R.M. (1985). Bivalvia from Nimar Sandstone, Bagh Beds, Jhabua District, Madhya Pradesh. Biovigyanam 11: 77-86.

Newton, R.B. (1909). Cretaceous Gastropoda and 
Pelecypoda from Zululand. Transactions of the Royal Society of South Africa 1: 1-106.

Nicol, D. (1950). Origin of the pelecypod family Glycymeridae. Journal of Paleontology 24: 89-98.

Ohno, T., Katoh, T. and Yamasu, T. (1995). The origin of Algal-Bivalve photo-symbiosis. Palaeontology 38: 121.

Oka, S.M. (1980). Study of desmoceratid ammonoids from the Upper Cretaceous of Trichinopoly District, South India. Unpublished Ph.D. thesis, the University of Poona.

Orbigny, A. d', (1844-1847). Paléontologie française. Description des Mollusques et Rayonnés fossiles. Terrains crétacés III. Lamellibranches. 1844: 1-288, pls 237-343; 1845: 289-448, pls 344-386; 1846: 449-520, pls 387-413; 1847: 521-807, pls 414-489.

Orbigny, A. d', (1847). Voyage au Pole Sud et dans L'Océanie sur les corvettes L'Astrolabe et La Zélée pendant les années 1837-1838-1839-1840 sous la commandement de $M$. Dumont-d'Urville, Capitaine de Vaisseau. Geologie. Paris. Gide et J. Baudry, éditeurs. 23 vols, 6 Atlas.

Orbigny, A. d', (1850). Prodrôme de Paléontologie stratigraphique universelle des animaux mollusques et rayonnés. II. Bivalvia cretacica: 72-84, 117-120, 135-139, 151-171, 194-198, 233-257.

Palmer, K.V.W. (1977). The unpublished vélins of Lamarck (1802-1809). Illustrations of fossils of the Paris Basin Eocene. Paleontological Research Institute, Ithaca, $67 \mathrm{pp}$.

Pervinquière, L. (1912). Études de Paléontologie Tunisienne II. Gastropodes et lamellibranches des terrains Crétacés. Régence de Tunis. Direction Générale des Travaux Publics. Carte Géologique de la Tunisie. Texte. J. Lamarre et Co., Paris.

Phansalkar, V.G. (1975). Palaeontological studies of the Acanthocerataceae from the Upper Cretaceous rock formations of Trichinopoly District, South India. Unpublished Ph.D. thesis, The University of Poona.

Ponder, W.F., Colman, P.H., Yonge, C.M. and Colman, M.H. (1981). The taxonomic position of Hemidonax Mörch, 1871 with a review of the genus (Bivalvia: Cardiacea). Journal of the Malacological Society of Australia 5: 41-64.

Purohit, M.G. (1980). Palaeontology of gastropods from the Upper Cretaceous of Trichinopoly District, South India. Unpublished Ph.D. thesis, The University of Poona.

Rajagopalan, N. (1965). Late Cretaceous and Early Tertiary stratigraphy of Pondicherry, south India. Journal of the Geological Society of India 6: 104-121.

Ramasamy, S. and Banerji, R.K. (1991). Geology, petrography and systematic stratigraphy of the preAriyalur sequence in Tiruchirapalli district, Tamil Nadu, India. Journal of the Geological Society of India 37: $577-594$.

Rao, N.K. (1964). Occurrence of the pelecypod genus Diploschiza Conrad in the Cretaceous rocks of Trichinopoly, India. Current Science 5: 143-145.

Rennie, J.V.L. (1929). Cretaceous fossils from Angola (Lamellibranchia and Gastropoda). Annals of the South African Museum $28: 1-54$.

Rennie, J.V.L. (1930). New Lamellibranchia and
Gastropoda from the Upper Cretaceous of Pondoland (with an appendix on some species from the Cretaceous of Zululand). Annals of the South African Museum 28: 159-260.

Sastry, M.V.A., Rao, B.R.J. and Mamgain, V.D. (1968). Biostratigraphic zonation of the Upper Cretaceous Formations of Trichinopoly District, south India. Memoirs of the Geological Society of India 2: 10-17.

Schneider, J.A. (1995). Phylogeny of the Cardiidae (Mollusca: Bivalvia): Protocardiinae, Laevicardiinae, Lahilliinae, Tulongocardiinae subfam. n. and Pleuriocardiinae subfam. n. Zoologica Scripta 24: 321 346.

Schneider, J.A. (1998). Phylogeny of stem-group eucardiids (Bivalvia: Cardiidae) and the significance of the transitional fossil Perucardia. Malacologia 40: $37-62$.

Schneider, J.A. (2002). Phylogeny of cardiid bivalves (cockles and giant clams): revision of the Cardiinae and the importance of fossils in explaining disjunct biogeographical distributions. Zoological Journal of the Linnaean Society 136: 321-369.

Schneider, J.A. and Carter, J.G. (2001). Evolution and phylogenetic significance of cardioidean shell microstructure (Mollusca, Bivalvia). Journal of Paleontology 75: 607-643.

Skwarko, S.K. (1983). Cenomanian (Late Cretaceous) Mollusca from Mountnorris Bay, Arnhem Land, northern Australia. Bureau of Mineral Resources, Australia Bulletin 217: 73-83.

Soares, F. and Silva, H. da (1970). Contribuição para o estudo da Geologia da Maputo. Estratigraphia e Paleontologia da Região da Madubula e suas relações com áreas vizinhas. Revista de Ciências Geológicas 3, Ser. A: 1-85.

Sowerby, J. and Sowerby, J. de C. (1812-1846). The Mineral Conchology of Great Britain; or coloured figures and descriptions of those remains of testaceous animals or shells which have been preserved at various times and depths in the earth. London, 7 vols.

Speden, I.G. (1967). Revision of Syncyclonema (Upper Cretaceous) and comparison with other small pectinid bivalves and Entolium. Postilla 110: 1-36.

Speden, I.G. (1970). The type Fox Hills Formation, Cretaceous, (Maestrichtian), South Dakota. Part 2. Systematics of the Bivalvia. Yale University Peabody Museum of Natural History Bulletin 33: 1-222.

Spengler, E. (1914). Nachtrage zur Oberkreidfauna des Trichinopoly Distriktes in Südindien. Beitrage zur Paläontologie Österreich-Ungarns 26: 213-221.

Spengler, E. (1923). Contributions to the palaeontology of Assam. Palaeontologica Indica 8, Memoir 1: 1-74.

Squires, R.L. and Saul, L.R. (2004). Cretaceous corbulid bivalves of the Pacific Slope of North America. The Veliger 47: 103-129.

Stenzel, H.B., Krause, E.K. and Twining, J.T. (1957). Pelecypoda from the type locality of the Stone City Beds (Middle Eocene) of Texas. University of Texas, Bureau of Economic Geology Publication 5704: 461.

Stilwell, J.D. (1993). New Early Paleocene Mollusca from the Wangaloa Formation of South Island, New Zealand. Journal of Paleontology 67: 360-369. 
Stilwell, J.D. (1998). Late Cretaceous Mollusca from the Chatham Islands, New Zealand. Alcheringa 22: 29-85.

Stilwell, J.D. and Henderson, R.A. (2002). Description and paleobiogeographic significance of a rare Cenomanian faunule from Bathurst Island, northern Australia. Journal of Paleontology 76: 447-471.

Stilwell, J.D. and McKenzie, E.D. (1999). First record of Acesta (Bivalvia: Limidae) from the Cretaceous of Australia. Alcheringa 23: 283-288

Stoliczka, F. (1867-1868). Cretaceous fauna of Southern India. The Gastropoda. Memoirs of the Geological Survey of India. Palaeontologica Indica, (4) 2: 1-204, pls 1-16 (1867); 205-498, pls 17-28 (1868).

Stoliczka, F. (1870-1871). Cretaceous fauna of Southern India. The Pelecypoda with a review of all known genera of this class, fossil and recent. Memoirs of the Geological Survey of India. Palaeontologica Indica, (6) 3: $1-222$, pls $1-12$ (1870); i-xxii, 223-538, pls $13-50$ (1871).

Sundaram, R., Henderson, R.A., Ayassami, K. and Stilwell, J.D. (2001). A lithostratigraphic revision and palaeoenvironmental assessment of the Cretaceous System exposed in the onshore Cauvery Basin, southern India. Cretaceous Research 22: 743-762.

Sundaram, R. and Rao, P.S. (1986). Lithostratigraphy of Cretaceous and Palaeocene rocks of Tiruchirapalli district, Tamil Nadu, South India. Records of the Geological Survey of India 115: 9-34.

Tapaswi, P.M. (1973). Bivalvia from the Upper Cretaceous of the Trichinopoly district, India. Unpublished Ph.D. thesis, The University of Poona.

Tapaswi, P.M. (1987). Taxonomic studies of the South Indian Cretaceous bivalves. Pages 505-514 in Geological Survey of India Special Publication 11. A collection of papers presented at the Symposium on Three Decades in Palaeontology and Stratigraphy in India, December 10-12, 1980, Hyderabad, India.

Tashiro, M. (1982). A new pectinid genus Nippononectes from the Cretaceous of Japan. Memoirs of the Faculty of Science, Kochi University, Series E, Geology 3: 1-6.

Tavani, G. (1942). III - fossili del Cretaceo 6 - Molluschi del Cretaceo della Somalia. Palaeontographia Italica 32, suppl. 4, fasc. 2.

Taylor, J.D., Cleevely, R.J. and Morris, N.J. (1983). Predatory gastropods and their activities in the Blackdown Greensand (Albian) of England. Palaeontology 26: 521-553.

Thomas, R.D.K. (1976). Constraints of ligament growth, form and function on evolution in the Arcoida (Mollusca: Bivalvia). Paleobiology 2: 64-83.

Thomas, R.D.K. (1978a). Shell form and the ecological range of living and extinct Arcoida. Paleobiology 4 181-194.

Thomas, R.D.K. (1978b). Limits to opportunism in the evolution of the Arcoida (Bivalvia). Philosophical Transactions of the Royal Society of London. B. 284: 335-344.

Tröger, K.-A. (1989). Problems of Upper Cretaceous inoceramid biostratigraphy and paleobiogeography in Europe and Western Asia. J. Weidman (ed.). Cretaceous of the Western Tethys. Proceedings of the Third International Cretaceous Symposium. Tübingen, 1987: 911-930.
Tschudin, P.E. (2001). Shell morphology, shell texture and species discrimination of Caribbean Tucetona (Bivalvia, Glycymeridae). Journal of Paleontology 75 : 658-679

Turner, R.D. (2002). On the subfamily Xylophagainae (family Pholadidae, Bivalvia, Mollusca). Bulletin of the Museum of Comparative Zoology 157: 223-308.

Vartak, A.V. (1990). Stratigraphy and palaeontology of heteromorph ammonoids from South Indian Cretaceous deposits. Unpublished Ph.D. thesis, The University of Poona

Venkatachalapathy, R. and Ragothaman, V. (1995). A foraminiferal zonal scheme for the mid-Cretaceous sediments of the Cauvery Basin, India. Cretaceous Research 16: 415-433.

Vokes, H.E. (1944). The validity of the molluscan genus Caestocorbula Vincent. American Journal of Science 242: 614-623.

Vokes, H.E. (1945). Supraspecific groups of the pelecypod family Corbulidae. Bulletin of the American Museum of Natural History 86: 1-32.

Wade, B. (1926). The fauna of the Ripley Formation on Coon Creek, Tennessee, U.S. Geological Survey Professional Paper 137: 1-271.

Waller, T.R. (1972). The functional significance of some shell microstructures in the Pectinacea (Mollusca: Bivalvia). International Geological Congress, Twenty Fourth Session, Montreal, Canada, Section 7, Palaeontology: 48-56.

Waller, T.R. (1978). Morphology, morphoclines and a new classification of the Pteriomorphia (Mollusca: Bivalvia). Philosophical Transactions of the Royal Society of London B. 284: 345-365.

Waller, T.R. (1984). The ctenolium of scallop shells: functional morphology and evolution of a key familylevel character in the Pectinacea (Mollusca: Bivalvia). Malacologia 25: 203-219.

Westermann, G.E.G. (2000). Marine faunal realms of the Mesozoic: review and revision under the new guidelines for biogeographic classification and nomenclature. Palaeogeography, Palaeoclimatology, Palaeoecology 163: 49-68.

Woods, H. (1899-1913). A Monograph of the Cretaceous Lamellibranchia of England. Palaeontographical Society Monographs I (1899): 1-72, pls 1-14; (1900): 73-112, pls 15-19; (1901): 113-144, pls 20-26; (1902): 145-196, pls 27-38; (1903): 197-232, pls 39-42. II. (1904): $1-56$, pls $1-7$; (1905): $57-96$, pls $8-11$; (1906): 97-132, pls 12-19; (1907): 133-180, pls 20-28; (1908): 181-216, pls $28-34$; (1909): 217-260, pls 35-44; (1911): 261-284, pls $45-50 ;(1912): 285-340$, pls $51-54 ;(1913)$ : 341-473, pls 55-62; London.

Woods, H. (1906). The Cretaceous fauna of Pondoland. Annals of the South African Museum 4: 275-350.

Woods, H. (1917). The Cretaceous faunas of the northeastern part of the South Island of New Zealand. New Zealand Geological Survey Palaeontological Bulletin 4.

Yonge, C.M. (1975). The status of the Plicatulidae and the Dimyidae in relation to the superfamily Pectinacea (Mollusca: Bivalvia). Journal of Zoology 176: 545-553.

Yonge, C.M. (1980). On the Dimyidae and Plicatulidae proposed new superfamily Plicatulacea. Journal of the Malacological Society of Australia 4: 241-242. 